UNIVERSIDADE DE SÃO PAULO INSTITUTO DE GEOCIENNCIAS

O ANEXO 2 ESTÁ EM UM DISQUETE QUE ENCONTRA-SE NA SEÇÃO DE REFERENCIA

\title{
HIDROGEOLOGIA DE BRASÍLIA - DF BACIA DO RIBEIRĀO SOBRADINHO
}

José Luiz Gomes Zoby

Orientador: Prof. Dr. Uriel Duarte

DISSERTAÇÃO DE MESTRADO

Programa de Pós-Graduação em Recursos Minerais e Hidrogeologia

SÃO PAULO

1999 


\title{
HIDROGEOLOGIA DE BRASÍLIA - DF BACIA DO RIBEIRÃO SOBRADINHO
}

JOSÉ LUIZ GOMES ZOBY

Orientador: Prof. Dr. Uriel Duarte

\author{
DISSERTAÇÃO DE MESTRADO
}

COMISSÃO JULGADORA

Nome

Presidente: Prof. Dr. Uriel Duarte

Examinadores: Dr. Hélio Nóbile Diniz

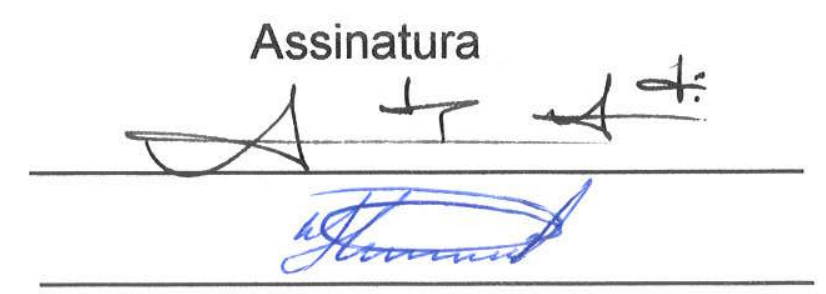

Prof. Dr. José Eloi Guimarães Campos

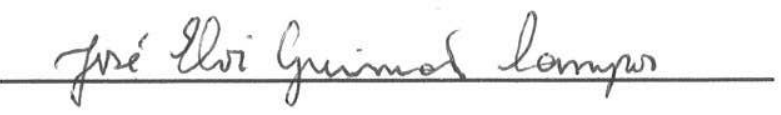

SÃO PAULO

1999 


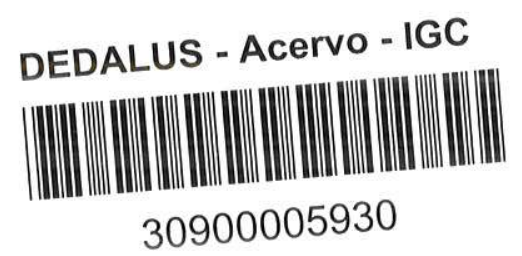

\section{HIDROGEOLOGIA DE BRASÍLIA - DF BACIA DO RIBEIRÃO SOBRADINHO}

José Luiz Gomes Zoby

Orientador: Prof. Dr. Uriel Duarte

DISSERTAÇÃO DE MESTRADO

Programa de Pós-Graduação em Recursos Minerais e Hidrogeologia 
Aos meus pais,

José Luiz e Maria Regina

e minha irmã,

Regina

com todo meu amor. 


\section{AGRADECIMENTOS}

É muito bom poder chegar ao fim de uma etapa da vida sabendo que existem pessoas com quem se pode contar. Por isso, gostaria de expressar meu sincero agradecimento àqueles que contribuíram para a realização deste trabalho.

A Deus pela vida e saúde.

A toda minha familia e, em especial, meus pais e minha irmã, as maiores riquezas que possuo.

Aos funcionários do Instituto de Geociências da Universidade de São Paulo.

Ao Prof. Dr. Uriel Duarte pela orientação, amizade, apoio e atenção em todos os momentos do trabalho.

Aos colegas da pós-graduação. Agradeço em especial às grandes amigas Valdeneide Regina da Silva, Ana Lúcia Berreta, Anísia Castro e Sívia Maria Ferreira.

Às empresas de perfuração de poços consultadas, em especial ao sr. Galvão da Colorado Poços Artesianos, e aos moradores da área de estudo por terem gentilmente cedido informações para o desenvolvimento do trabalho.

A Laurentino e Rosana Batista pelo incentivo e apoio.

À CAESB ( Companhia de Água e Esgotos de Brasilia), em especial na pessoa de Eliane Costa.

Aos amigos de Brasília e principalmente ao Ricardo Algarte.

Ao CNPq pela bolsa de estudos e à FAPESP pelo financiamento do projeto. 


\section{SUMÁRIO}

INDICE DE FIGURAS

ÍNDICE DE TABELAS vi

ÍNDICE DE FOTOS viii

INDICE DE ANEXOS $\quad$ ix

RESUMO

ABSTRACT

1. INTRODUÇÃO

1.1 LOCALIZAÇÃO DA ÁREA DE ESTUdO

1.2 OBJETIVOS

1.3 Metodologia

2. Caracterização da Área de Estudo 10

2.1 ASPECTOS DE USO E OCUPAÇÃO dO SOLO 10

2.2 GEOMORFOLOGIA 12

2.3 GEOLOGIA

2.3.1 CONTEXTO GEOLOGICO REGIONAL.

2.3.2. GEOLOGIA DA ÁREA DE ESTUDO 19

2.3.3 ARCABOUÇO ESTRUTURAL DO DISTRITO FEDERAL 23

2.4 HIDROGRAFIA $\quad 26$

2.5 SOLOS $\quad 27$ 
3.1 LEVANTAMENTO E AQUISIÇÃO DE DADOS HIDROLÓGICOS 30

3.2 PRINCIPAIS PARÂMETROS CLIMÁTICOS CONSIDERADOS 32

3.2.1 PRECIPITAÇÃO $\quad 32$

3.2.2 TEMPERATURA 34

3.2.3 UMIDADE DO AR E VELOCIDADE DO VENTO 35

3.2.4 EVAPOTRANSPIRAÇÃO POTENCIAL.

3.3 BALANÇO HIDRICO 36

4. HIDROGEOLOGIA 38

$\begin{array}{ll}4.1 \text { INTRODUÇÃO } & 38\end{array}$

4.2 TRABALHOS ANTERIORES $\quad 44$

4.3 DEFINIÇÃo E CLASSIFICAÇÃo dOS AQÜIFEROS

4.3.1 DOMINIO POROSO $\quad 47$

4.3.2 DOMINIO FRATURADO

4.3.2.1 SISTEMA PARANOA 52

A) SUbSISTEMA METARRITMITO ARENOSO 52

B) SUBSISTEMA QUARTZITO $\quad 54$

C) SUBSISTEMA METARRITMITO ARglloso

D) Subsistema Psamo-Pelito Carbonatado 56

4.3.2.2 SISTEMA CANASTRA 58

4.4 CARACTERIZAÇÃo do FRATURAMENTO $\quad 59$

4.5 AVALIAÇÃO DO AQÜIFERO FRATURADO 63

4.5.1 PROFUNDIDADE DAS ENTRADAS DE AGUA 63

4.5.2 RELAÇÃO PRODUTIVIDADE DOS POÇOS E LINEAMENTOS 65

4.5.3 CRITÉRIOS PARA LOCAÇÃO DE POÇOS $\quad 66$

$\begin{array}{ll}\text { 4.6 ASPECTOS DA RECARGA E ESCOAMENTO } & 67\end{array}$ 
5.1 POÇOS PROFUNDOS

5.1.1 HISTORICO DAS PERFURAÇÓES

5.1.2 ESTADO ATUAL DOS POÇOS

5.1.3 LOCAÇÃO

5.1.4 CARACTERISTICAS TÉCNICAS DE CONSTRUÇÃO

5.1.5 CARACTERISTICAS DE USO E EXPLOTAÇÃO 80

5.1.6 ASPECTOS DE PROTEÇÃO E CAPTAÇÃO DOS POÇOS 85

5.1.7 POÇOS ABANDONADOS E DESATIVADOS $\quad 87$

$\begin{array}{ll}5.2 \text { POÇOS RASOS } & 90\end{array}$

5.2.1 SITUAÇÃo ATUAL $\quad 90$

5.2.2 CARACTERISTICAS TÉCNICAS DE CONSTRUÇÃo 91

5.2.3 CARACTERISTICAS DE USO E EXPLOTAÇÃO 95

6 HIDROGEOQUÍMICA $\quad 98$

6.1 PARÂMETROS Físicos E ORGANOLÉPTICOS 99

6.2 PARÂMETROS QUÍMICOS 100

$\begin{array}{ll}\text { 6.3 CLASSIFICAÇÃO DAS AGUAS } & 106\end{array}$

$\begin{array}{ll}\text { 6.4 QUALIDADE DAS AGUAS } & 106\end{array}$

$\begin{array}{ll}\text { 6.4.1 ASPECTOS FISICO-QUIMICOS } & 106\end{array}$

6.4.2 ASPECTO BACTERIOLOGICO 110

6.5 ASPECTOS DA EVOLUÇÃO DA COMPOSIÇÃO QUIMICA 113

$\begin{array}{ll}\text { 7. CONCLUSÕES } & 116\end{array}$

$\begin{array}{ll}\text { REFERÊNCIAS BIBLIOGRÁFICAS } & 120\end{array}$

\section{ANEXOS}


INDICE DE FIGURAS

Figura 1. Localização da área de estudo.

Figura 2. Mapa geomorfológico do Distrito Federal (Novaes Pinto 1986) com a localização da área de estudo.

Figura 3. Posicionamento do Distrito Federal na Faixa Brasilia (Schobbenhaus et al. 1981 apud Fuck et al. 1992).

Figura 4. Mapa geológico do Distrito Federal (Freitas-Silva \& Campos 1998).

Figura 5. Coluna litoestratigráfica do Grupo Paranoá no Distrito Federal (Freitas-Silva \& Campos 1998). $\mathrm{Na}$ área de estudo ocorrem as unidades $R_{3}, Q_{3}, R_{4}$ e PPC.

Figura 6. Mapa da rede de drenagem (extraida a partir de fotos aéreas de escala 1:40.000). 28

Figura 7. Mapa de isoietas da área de estudo e de localização das estações hidrológicas.

Figura 8.Variação da precipitação média mensal nas estações de Sobradinho e do CPAC/EMBRAPA (período 1979 a 1995).

Figura 9. Variação da precipitação média anual das estações analisadas (foram considerados anos de precipitação normal aqueles com valores que se afastam até 13\% (200 mm) da média total das estações).

Figura 10. Variação da temperatura média mensal na estação CPAC/EMBRAPA (período de 1979 a 1995).

Figura 11. Hidrograma do ribeirão Sobradinho (valores médios mensais correspondentes ao período de 1979 a 1995). 
Figura 12. Mapa hidrogeológico do Domínio Fraturado (mapa modificado a partir de Campos \& Freitas-Silva (1998)).

Figura 13. Perfil hidrogeológico esquemático mostrando a estrutura em sinclinal da bacia do ribeirão Sobradinho e os principais subsistemas aqüiferos da área de estudo (a orientação do perfil esá indicada na figura 12, página 53).

Figura 14. Mapa de lineamentos estruturais extraídos a partir de fotos aéreas de escala $1: 40.000$.

Figura 15. Estereograma equiárea (Schmidt - concentração por $1 \%$ de área ) sinóptico de pólos das fraturas. Observar o predominio das famílias de fraturas de direção N5W e N30E, e subordinadamente das famílias N54W e N53E (isolinhas a cada 1,08\%; número de fraturas $=371$ ).

Figura 16. Profundidade das entradas de água nos subsistemas aqüíferos estudados.

Figura 17. Mapa relacionando lineamentos e vazão específica dos poços nos diferentes subsistemas aqüiferos.

Figura 18. Principal tipo de fonte observada na área de estudo e importante exutório do manto de intemperismo. A surgência normalmente ocorre de forma difusa, onde contato entre embasamento e manto de intemperismo aflora na superfície.

Figura 19. Mapa de localização das obras de captação de água subterrânea cadastradas. 72

Figura 20. Evolução do número de poços perfurados na área de estudo entre 1988 e 1998. (dois poços cadastrados não possuiam informações quanto ao ano da perfuração).

Figura 21. Diagrama de Piper para classificação das águas subterrâneas.

Figura 22. Diagrama SAR para classificação de águas para irrigação (US Salinity Laboratory Staff 1957). 


\section{INDICE DE TABELAS}

Tabela 1. Estações consideradas para a análise climática da área de estudo ( ${ }^{*}$ a altitude foi estimada com base nos mapas planialtimétricos 1:25.000 do (BGE/CODEPLAN).

Tabela 2.Valores médios mensais de umidade relativa do ar e velocidade do vento na estação CPAC/EMBRAPA (periodo de 1979 a 1995).

Tabela 3. Valores médios mensais de evapotranspiração potencial obtidos através do método de Penman (dados da estação EMBRAPA-CPAC).

Tabela 4. Resumo das classificações dos dominios, sistemas e subsistemas aqüiferos do Distrito Federal propostas por Barros (1987) e Campos \& Freitas-Silva (1998).

Tabela 5. Variações de espessura no manto de intemperismo (solo e saprolito) em função do substrato geológico.

Tabela 6. Parâmetros hidráulicos dos poços do subsistema aqüifero Metarritmito Argiloso. ( foram considerados apenas poços com perfis construtivo e litológico completos).

Tabela 7. Parâmetros hidráulicos dos poços do subsistema aqüifero Quartzito. (* foram considerados apenas poços com perfis construtivo e litológico completos).

Tabela 8. Parâmetros hidráulicos dos poços dos subsistemas aqüífero Metarritmito Argiloso e misto (Metarritmito Argiloso/Quartzito). ( ${ }^{*}$ foram considerados apenas poços com perfis construtivo e litológico completos).

Tabela 9. Parâmetros hidráulicos dos poços do subsistema aqülífero Psamo-Pelito Carbonatado. ( ${ }^{*}$ foram considerados apenas poços com perfis construtivo e litológico completos). $\quad 57$

Tabela 10. Empresas de perfuração de poços que atuaram na área de estudo.

Tabela 11. Situação atual dos poços.

Tabela 12. Número de diâmetros utilizados na perfuração dos poços.

Tabela 13. Classes de profundidade dos poços. 
Tabela 14. Número de revestimentos utilizados nos poços.

Tabela 15. Informações técnicas disponiveis sobre os filtros dos poços.

Tabela 16. Regime de explotação diária dos poços.

Tabela 17. Tipos de usos da água dos poços tubulares.

Tabela 18.Tipos de usuários de água de poços tubulares.

Tabela 19. Caracteristica dos poços avaliados em relação à cimentação.

Tabela 20. Padrões de potabilidade adotados ( ${ }^{*}$ água entrando no sistema de distribuição). 108 


\section{INDICE DE FOTOS}

Foto 1. Poço com tampa mal fixada e deslocada. Existem deficiências técnicas construtivas devido à ausência da laje de proteção sanitária e a saliência do tubo de revestimento interno, que não obedece à altura mínima de $50 \mathrm{~cm}$ recomendada pela ABNT (1990).

Foto 2. Poço apresenta a sua extremidade superior (boca do poço) localizada dentro de caixa de cimento parcialmente abaixo do solo em que existe acúmulo de lixo e sucata.

Foto 3. Poço sem laje sanitária e desativado sem qualquer tipo de preocupação sanitária, evidenciada pela falta de vedação.

Foto 4. As condições de higiene são em geral, precárias quando se utiliza o sarritho com corda e balde. O poço raso apresenta deficiências técnicas construtivas representadas pela ausência de laje de proteção sanitária, borda do poço praticamente ao nivel do solo e tampa de madeira que não oferece boa vedação. 
INDICE DE ANEXOS

ANEXO 1 - Fichas de cadastro

ANEXO 2 - Banco de dados das obras de captação de água subterrânea (em disquete)

ANEXO 3 - Resultados das análises físico-químicas e bacteriológicas das águas 


\section{Resumo}

A bacia do ribeirão Sobradinho se localiza na porção centro-norte do Distrito Federal e apresenta uma área de $144 \mathrm{~km}^{2}$. A água subterrânea se tornou importante alternativa de abastecimento para uma significativa parcela da população. Os dados levantados indicam que pelo menos 22.500 pessoas dependem exclusivamente do recurso hídrico subterrâneo.

A área estudada é representada geologicamente por metassedimentos de idade proterozóica deformados durante o Ciclo Brasiliano (650 Ma), que encontram-se recobertos por espesso manto de intemperismo.

Foram individualizados dentro do contexto hidrogeológico local, os domínios aqüiferos Poroso e Fraturado. O Domínio Fraturado foi classificado em dois sistemas denominados de Paranoá e Canastra. O Sistema Paranoá foi subdividido em quatro subsistemas aqüiferos: Metarritmito Arenoso (média de vazões de $26,7 \mathrm{~m}^{3} / \mathrm{h}$ ), Quartzito (média de vazões de $8,7 \mathrm{~m}^{3} / \mathrm{h}$ ), Metarritmito Argiloso (média de vazões de $4,6 \mathrm{~m}^{3} / \mathrm{h}$ ) e Psamo-Pelito Carbonatado (média de vazões de $15,7 \mathrm{~m}^{3} / \mathrm{h}$ ). Como não foram cadastrados na área poços pertencentes ao Sistema Canastra ele foi considerado indiviso. As principais fraturas produtoras nos poços ocorrem próximas à superfície, concentrando-se em profundidades de até $100 \mathrm{~m}$.

O Domínio Poroso está associado, na região, ao manto de intemperismo (solo e saprolito), que chega até a mais de $100 \mathrm{~m}$ de espessura, sendo representado por aqüiferos livres, de grande continuidade lateral. A espessura e permeabilidade do manto de intemperismo apresentam grande controle em função do substrato geológico. O Dominio Poroso é explotado na região através de poços rasos.

A precipitação média anual na área estudada é de $1442,5 \mathrm{~mm}$. Cerca de $28 \%$ do volume precipitado participa da recarga dos aqüiferos.

O principal uso da água subterrânea na região é o domiciliar. As águas dos aqüiferos poroso e fraturado são de boa qualidade físico-química. A contaminação bacteriológica observada em amostras de água do manto de intemperismo está relacionada às deficiências construtivas dos poços rasos e à proximidade entre fossa e poço. Foram observadas deficiências técnicas construtivas em relação à proteção sanitária e aos processos de desativação e abandono dos poços profundos. 


\section{ABSTRACT}

The Sobradinho river basin is located in the center-north portion of the Distrito Federal and comprises an area of $144 \mathrm{~km}^{2}$. The groundwater has become an effective alternative of supply for an important part of the population. At least 22,500 persons depend on it.

The studied area is geologically composed by metasedimentary rocks of proterozoic age deformed during the Brasiliano Cycle (650 My) covered by a thick weathering mantle.

Two aquifer domains were individualized in the hydrogeological context which are the Porous Domain and the Fractured Domain. The Fractured Domain was classified in two systems named Paranoá and Canastra. The Paranoá System was subdivided in four aquifer systems: Metarritmito Arenoso (mean yield $26.7 \mathrm{~m}^{3} / \mathrm{h}$ ), Quartzito (mean yield $8.7 \mathrm{~m}^{3} / \mathrm{h}$ ), Metarritmito Argiloso (mean yield $4.6 \mathrm{~m}^{3} / \mathrm{h}$ ) e Psamo-Pelito Carbonatado (mean yield 15.7 $\mathrm{m}^{3} / \mathrm{h}$ ). As there were no wells in the Canastra System it remained undivided. The main producing fractures in the wells occur near the surface and are concentrated until the $100 \mathrm{~m}$ deepnes.

The Porous Domain is related in the area to the weathering mantle (soil and weathered rock) that achieves more than $100 \mathrm{~m}$ thickness, and is associated to unconfined aquifers of great lateral continuity. The thickness and permeability of the weathering mantle are strongly influenced by the geological basement. The Porous Domain is exploited in the study area by excavated wells.

The mean annual precipitation in the area is of $1,442.5 \mathrm{~mm}$. Approximately $28 \%$ of the volume precipitated takes part in the aquifer recharge.

The main use of the groundwater is the domestic. The waters of the porous and fractured aquifers have good physical-chemical quality. The bacteriological contamination in water samples from the weathering mantle are related to the technical constructive deficiencies of the excavated wells and the nearness between cesspit and well. Technical constructive problems with sanitary protection and procedures of unactivation and abandonment of the deep groundwater wells were recognized. 


\section{INTRODUÇÃO}

O Distrito Federal (DF) foi planejado para abrigar a capital do país, uma cidade de médio porte (Brasília), e suas cidades satélites (Taguatinga, Planaltina, Brazlândia, Sobradinho entre outras), que deveriam ser circundadas por um cinturão verde. Passadas mais de três décadas da sua fundação, a região apresenta um nivel de desenvolvimento e crescimento muito acima daqueles previstos inicialmente.

O censo demográfico revelou no ano de 1991, população de cerca de 1.600 .000 habitantes, quando o valor previsto para o ano 2000 era de apenas 500.000 habitantes. A comparação com dados censitários anteriores revela que a população aumentou cerca de 11 vezes no periodo entre os censos de 1960 e 1991, um processo que está ligado principalmente ao efeito da migração. Como conseqüência deste crescimento demográfico, desenvolveram-se basicamente os setores de comércio e de serviços. $\mathrm{Na}$ área rural, a expansão das atividades agropecuárias foi significativa.

Desta forma, o DF se transformou rapidamente em um pólo de desenvolvimento que gerou uma significativa mudança no quadro de ocupação e de expansão da região. Uma das características deste processo fol o seu elevado grau de urbanização, que produziu uma defasagem nos serviços básicos como esgotos, energia elétrica e abastecimento de água. Surgiu também uma série de problemas ambientais como diferentes formas de poluição do ar, solo e águas, redução da vegetação natural e surgimento de processos erosivos superficiais e subterrâneos. Recentemente têm surgido também discussões sobre questões como a disposição dos resíduos sólidos e localização de aterros sanitários.

O gerenciamento do recurso hídrico é uma questão que vem se tornando cada vez mais importante no DF, não apenas pelo aumento da demanda de água, mas também pelos impactos ambientais relacionados ao lançamento de esgotos domésticos sem tratamento, a utilização indiscriminada de agrotóxicos, a erosão e o assoreamento de rios, entre outros.

O abastecimento de água no DF é realizado através da captação de águas superficiais dos sistemas Santa Maria/Torto e do Descoberto, sendo complementado por dezessete pequenas e médias captações. Este quadro é relativamente preocupante em função do crescimento da demanda e também das carateristicas geomorfológicas da região, cuja área é constituída de terras altas que funcionam como dispersoras das drenagens. Os rios da região são de pequeno a médio porte, por isso pequenas e médias captações são utilizadas para suprir regiões com alto déficit de abastecimento.

A água subterrânea vem se apresentando como uma alternativa complementar ao abastecimento por águas superficiais. A CAESB (Companhia de Água e Esgotos de Brasília) 
atualmente utiliza a água subterrânea para abastecer comunidades rurais e de forma complementar em áreas urbanas. A cidade satélite de São Sebastião entretanto, é totalmente abastecida por poços tubulares profundos.

A grande demanda pelo recurso hídrico subterrâneo na região vem dos denominados condomínios, que surgiram do parcelamento irregular do solo. No ano de 1996, o DF apresentava 530 condomínios dos quais 232 foram considerados como já implantados (IPDF 1996). Esses loteamentos tornaram-se ao longo dos anos uma importante oportunidade de acesso a moradia, especialmente para a classe média. Por outro lado, criaram uma série de impactos ambientais, aos quais somam-se problemas de infraestrutura, como de esgotamento sanitário e rede pluvial. O abastecimento de água nestes locais vem sendo realizado por iniciativa individual para cada parcelamento, pelos próprios moradores ou pelo empreendedor, sendo a maior parte através de água subterrânea, na forma de poços tubulares profundos e também de poços rasos (cacimbas).

A cidade satélite de Sobradinho e o assentamento Sobradinho II, integrantes da bacia do ribeirão Sobradinho, são um exemplo desta situação. A característica marcante desta área é o intenso processo de parcelamento do solo, que se intensificou principalmente na década de 90 . Atualmente a região encontra-se densamente povoada, apresentando alguns dos condomínios mais antigos e consolidados do DF, que têm na sua maior parte a água subterrânea como principal fonte de abastecimento. $\mathrm{O}$ assentamento Sobradinho II até 1997 era abastecido exclusivamente através de poços tubulares profundos. Alguns dos aqüiferos mais importantes do DF ocorrem na região. Além disso, como o processo de ocupação do solo na região ainda continua, a demanda pelo recurso hídrico subterrâneo tende a crescer.

Apesar do crescente interesse pela explotação dos aqüiferos da região, o que se verifica é a escassez de estudos sobre o recurso hídrico que permitam subsidiar processos decisórios que levem em conta a sua sustentabilidade. Este tipo de análise envolve aspectos como da necessidade de preservação e proteção das águas subterrâneas, e até mesmo sobre o seu potencial como alternativa de abastecimento. No DF existe uma carência de estudos hidrogeológicos detalhados, já que aqueles disponiveis são de caráter regional. Surgem portanto, questionamentos sobre o potencial hídrico dos aqüiferos da região, seu atual estágio de explotação e da necessidade de proteção das águas subterrâneas. 


\subsection{LOCALIZAÇÃo dA ÁREA DE ESTUdo}

A bacia do ribeirão Sobradinho localiza-se na região centro-norte do DF (figura 1), possui uma área de drenagem de aproximadamente $144 \mathrm{~km}^{2}$ e faz parte da bacia do rio São Bartolomeu, a maior do DF. O rio São Bartolomeu é formado pela confluência dos ribeirões Monteiro e Pipiripau na região nordeste do DF e segue em direção aproximada SSO, ao longo de um percurso de $52 \mathrm{~km}$ até alcançar o estado de Goiás.

O ribeirão Sobradinho é um dos principais tributários da margem direita do rio São Bartolomeu. Ele nasce no Morro do Canastra, próximo à cidade Sobradinho, e segue em direção SE até próximo a sua confluência com o rio São Bartolomeu, onde então apresenta direção aproximada $\mathrm{EW}$.

O acesso à área a partir de Brasilia pode ser feito tomando na região do Torto a DF-

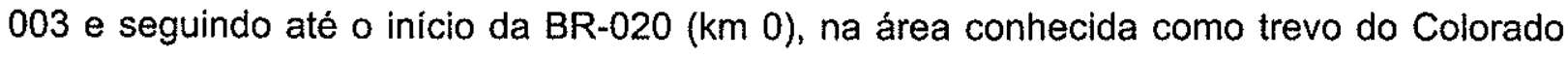
(figura 1).

\subsection{OBJetivos}

Os principais objetivos desta pesquisa foram:

- Contribuir para um melhor conhecimento dos aqüiferos da área de estudo;

- Avaliar as condições de explotação da água subterrânea e caracterizar a sua qualidade;

- Fornecer subsídios para a gestão dos recursos hídricos subterrâneos na bacia do ribeirão Sobradinho, de modo a compatibilizar um desenvolvimento sustentável de sua explotação. 


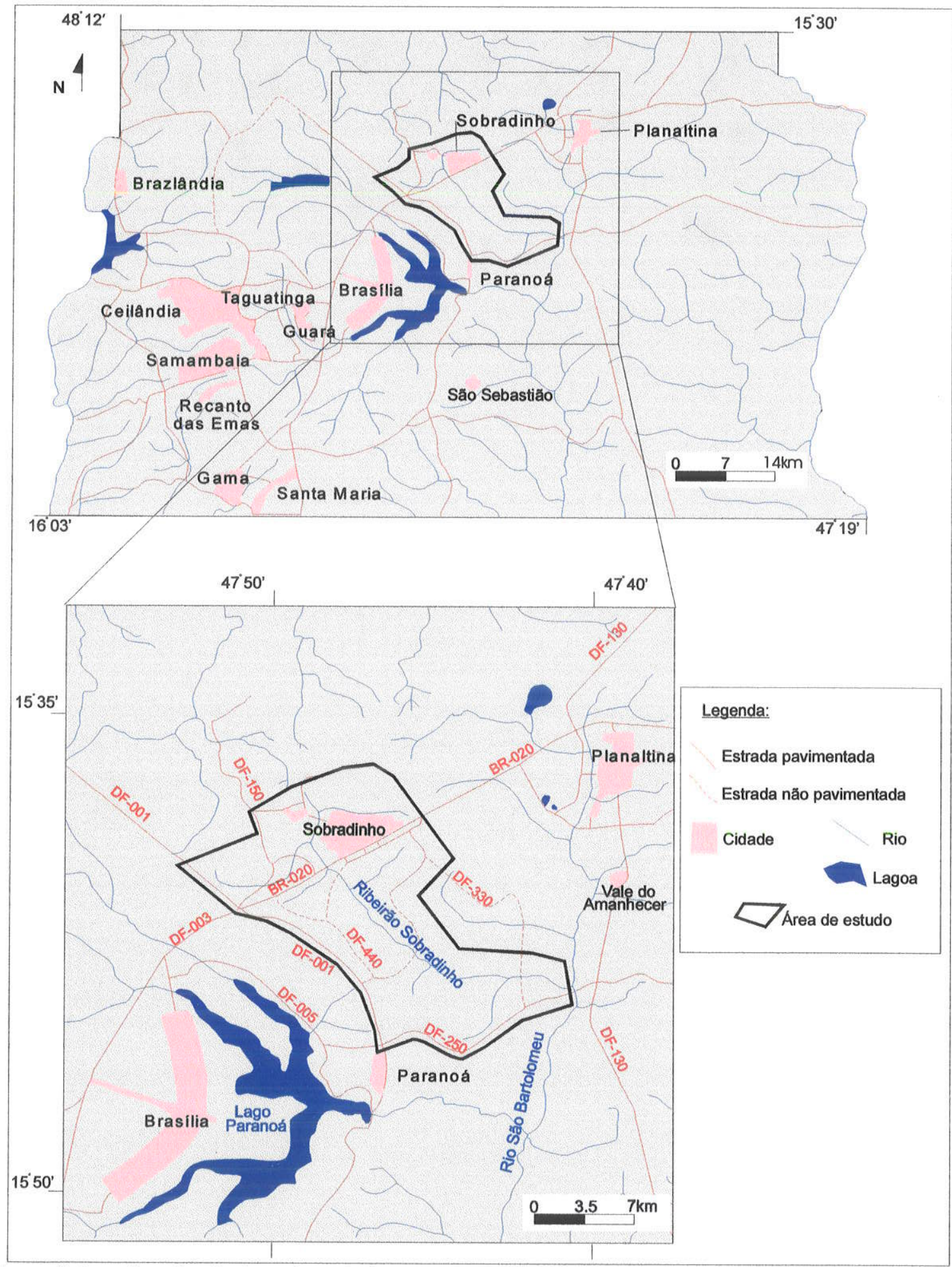

Figura 1. Localização da área de estudo. 


\subsection{MetOdologia}

O estudo foi dividido em diferentes etapas consecutivas, que forneceram subsídios para o desenvolvimento dos tópicos, de modo a atingir os objetivos propostos.

\section{- Pesquisa Bibliográfica}

$\mathrm{Na}$ etapa inicial do estudo foi realizado o levantamento da bibliografia relativa ao estágio atual de conhecimento da geologia, geomorfologia, pedologia e hidrogeologia do DF. Foram adquiridos mapas planialtimétricos, geológicos e hidrogeológicos existentes em escalas diversas, a fim de se fazer a integração para o estudo regional e local.

Para melhor caracterizar a área estudada, foi realizada uma compilação dos dados disponiveis sobre clima, hidrografia e hidrologia. Estes levantamentos forneceram subsídios para o cálculo do balanço hídrico da região.

Como a utilização da água subterrânea e as suas condições de proteção e uso são função do uso e ocupação do solo, foi realizada pesquisa sobre o histórico de ocupação da área de estudo, abordando também aspectos sócio-econômicos da população. Informações sobre saneamento básico na região foram obtidos através da CAESB.

Devido à grande importância do aqüifero fraturado como fonte de abastecimento da população na área de estudo, foi realizada uma sintese dos aspectos fundamentais sobre este tipo de aqüifero.

\section{- Cadastramento das Obras de Captação}

O cadastramento das obras de captação de água subterrânea é a etapa inicial e fundamental para o reconhecimento e caracterização dos aqüiferos de uma região. Foram obtidas informações hidrogeológicas (perfil litológico, nível estático, nível dinâmico, etc...), sobre o uso e regime de explotação da água subterrânea, e avaliados aspectos da construção e conservação das obras de captação.

A primeira etapa do estudo partiu da elaboração de fichas (anexo 1) que tiveram a função de determinar os dados a serem levantados e, principalmente, orientar e uniformizar a sua obtenção no campo. Como na área de estudos haviam sido previamente reconhecidos dois tipos básicos de obras de captação (poços tubulares e poços rasos), foram elaboradas duas fichas distintas de forma a atender as especificidades construtivas de cada um deles. A ficha para avaliação dos poços tubulares baseia-se, em grande parte, nas considerações e avaliações realizadas no município de São Paulo (Pacheco 1984).

Em seguida, foi realizado um levantamento junto às principais empresas de perfuração de poços profundos no DF, de modo a obter os dados disponíveis em arquivos, fichas e perfis dos poços localizados na área de estudo. Esta etapa teve como objetivo 
caracterizar os aspectos técnicos da obra, tais como tipo e diâmetro de revestimento, posição e tipos de filtro, testes de produção e desenvolvimento, perfil litológico entre outros.

Durante as atividades de campo, os poços profundos tiveram a confirmação dos seus endereços de localização, tendo sido definidas suas coordenadas geográficas através de GPS (Ground Positioning System) das marcas Garmin II e Magellan Trailblazer. Nos locais de grande concentração de poços, além do GPS, foram utilizadas as folhas topográficas da CODEPLAN (Companhia de Desenvolvimento do Planalto Central) em escala 1:10.000, que fazem parte do SICAD (Sistema Cartográfico do Distrito Federal).

As fichas de cadastro foram, então, complementadas pela avaliação no local da situação atual do poço (desativado, em explotação), a qualidade técnica da obra (laje de proteção, cimentação, tampa, altura do tubo de boca, etc...) e o seu posicionamento em relação a possiveis fontes de poluição e/ou contaminação. Os proprietários ou usuários forneceram informações complementares como regime de explotação do poço, uso da água, equipamento de bombeamento, tipo de manutenção, dados de análises físico-químicas e bacteriológicas da água.

A mesma metodologia utilizada para os poços tubulares foi adotada na avaliação dos poços rasos. Entretanto, neste caso, os proprietários forneceram informações sobre a profundidade do poço e o nivel estático foi medido utilizando medidor elétrico, que consta de dois pólos e um ohmímetro analógico que indica o fechamento do circuito quando se atinge a água.

Com o preenchimento das fichas de cadastro foi possivel criar um banco de dados (anexo 2) que contém as informações básicas sobre as obras de captação de água subterrânea. Para a informatização dos dados, utilizou-se o programa EXCEL. Além do armazenamento das informações básicas relativas aos poços, foram calculados os parâmetros de rebaixamento e capacidade especifica. A base topográfica utilizada para determinação da cota altimétrica dos poços foram as folhas 1:25.000 do IBGE/CODEPLAN de 1984. Posteriormente, com as coordenadas geográficas de cada poço, foi elaborado mapa topográfico contendo a localização das obras de captação de água subterrânea cadastradas na área. Foram utilizados como mapas-base as folhas Sobradinho, Brasilia-NE, Vale do Amanhecer e Rio Paranoá, e a digitalização foi realizada através do software AUTOCAD. 


\section{- INTerpretação fotogeológica e Geologia de Campo}

No estudo do aqüifero fraturado, foi dada atenção especial às feições estruturais geradas no regime rúptil de deformação, especialmente as fraturas, já que estas são as que maior controle exercem sobre a circulação da água neste tipo de meio. Foi realizada a interpretação de fotos aéreas, tendo sido escolhidas as de escala 1:40.000 do levantamento de 1975, realizado pelo Ministério da Aeronáutica para a CODEPLAN. A escolha destas fotos se deveu essencialmente a dois fatores. O primeiro é que a escala escolhida se revelou bastante adequada para a extensão dos lineamentos observados na área de estudo e o segundo é que, como o levantamento aerofotográfico é relativamente antigo, nas fotos a área encontra-se menos ocupada e os menores lineamentos podem ser melhor extraídos.

Durante os trabalhos de campo foram tomadas medidas estruturais com ênfase principalmente na caracterização das fraturas. As medidas de fraturamento foram realizadas em diversos afloramentos e, sempre que possível, caracterizou-se se eram abertas ou fechadas, preenchidas, e neste caso a composição do preenchimento. A partir dos dados obtidos, foram elaborados diagramas de rosetas e de análise estrutural.

O cruzamento do mapa de lineamentos fotointerpretados e dos diagramas estruturais das medidas de fraturamento foi interpretado dentro do contexto tectônico regional, possibilitando uma melhor compreensão da tectônica rúptil atuante na região.

\section{- Caracterização Hidrogeológica}

Dos poços cadastrados, foram posteriormente selecionados aqueles com dados mais completos incluindo parâmetros hidráulicos, tais como níveis estático e dinâmico, vazão, e perfis construtivo e geológico. Estes poços foram analisados, de modo a permitir o estudo do comportamento hidrodinâmico da água nos diferentes aqüiferos.

Os dados hidrodinâmicos foram tratados através da estatística e correlacionados a fatores como litologia, compartimentação topográfica e profundidade, para permitir uma avaliação dos fatores que controlam a produtividade dos poços. Esta análise visou estabelecer parâmetros para a definição e classificação dos sistemas aqüíferos. Os dados obtidos sobre o padrão de fraturamento da área associados aos dados dos poços foram correlacionados de modo a permitir o conhecimento dos condicionantes morfológicos e geológico-estruturais, que controlam o comportamento hidrogeológico dos aqüiferos fraturados.

A análise dos perfis geológicos dos poços buscou caracterizar o manto de intemperismo da região. Foram avaliadas as variações laterais e verticais de espessura e granulometria do regolito. 
Foi realizada uma análise das condições de recarga e das feições geológicas que controlam o escoamento da água nos aqüiferos da região. Os mecanismos de recarga foram relacionados a aspectos como topografia e uso/ocupação do solo na área de estudo.

\section{- avaliação das Obras de Captação}

Esta etapa buscou avaliar o atual estágio de explotação e utilização da água subterrânea através da avaliação das obras de captação na área. Foram abordadas questões relativas às condições de uso e proteção das águas, de construção, manutenção e operação dos poços rasos e profundos, entre outros. Esta análise foi baseada nas informações contidas no banco de dados.

\section{- ANÁlises Fisico-Químicas e Bacteriológicas de Água}

As análises físico-químicas e bacteriológicas tiveram como objetivo principal uma caracterização espacial da qualidade da água na área estudada. Foram avaliados alguns aspectos relativos à sua qualidade para diversos fins, identificando eventuais efeitos relacionados à atividade antrópica. A caracterização hidroquimica permitiu uma melhor compreensão da origem e grau de mineralização das águas.

Foi realizada a coleta de 50 amostras de água distribuídas entre 25 de poços tubulares profundos e 25 de poços rasos. A coleta foi realizada durante os meses de julho e agosto de 1998, que corresponde ao periodo de seca na região, de forma a reduzir a influência das águas pluviais, que alteram quimicamente a composição química da água subterrânea. A escolha dos pontos de coleta levou em conta critérios distintos para poços tubulares e poços rasos.

No caso dos poços tubulares foram adotados os seguintes critérios:

- pontos com representação espacial em função da densidade de poços, buscando uma distribuição mais homogênea possivel ao longo da área estudada;

- confiabilidade dos perfis dos poços com relação, principalmente, à unidade aqüífera explotada;

- funcionamento constante, de forma a garantir uma constante renovação da água assegurando boa representatividade das águas do aqüífero.

Com relação aos poços rasos os principais critérios para seleção foram:

- pontos com representação espacial em função da densidade de poços, buscando uma distribuição mais homogênea possivel ao longo de toda a área estudada;

- em locais de grande concentração de poços rasos e fossas a escolha foi feita em função dos locais que apresentavam maior possibilidade de contaminação e/ou poluição. 
As amostras foram coletadas e preservadas de acordo com o guia técnico de coleta de amostras de água da CETESB (1988). Os recipientes para coleta de água foram fornecidos pelos laboratórios de análise e a amostragem foi realizada sempre com os poços em funcionamento. No caso das bombas estarem desligadas no instante da amostragem, foram aguardados de 3 a 5 minutos de bombeamento para renovar a água parada no sistema de bombeamento.

Com o objetivo de evitar interferências nas características físico-químicas e bacteriológicas das águas, a coleta foi feita diretamente na saída dos poços, antes de seu armazenamento nos reservatórios de distribuição e/ou qualquer tratamento da água. No caso dos poços rasos que não possuíam equipamento de bombeamento, as amostras foram coletadas mergulhando os frascos suspensos por fios de náilon.

Os frascos para a análise físico-química foram lavados com a própria água a ser analisada antes da coleta. No momento da coleta foram analisados os seguintes parâmetros:

- pH com auxílio de um pHmetro portátil (Orion - Quikcheck 106);

- condutividade elétrica com um condutivímetro portátil (Orion - Quikcheck 116);

- temperatura da água com o uso de termômetro digital portátil (Orion - Quikcheck 108).

Os frascos de coleta foram totalmente preenchidos com água a fim de evitar a possibilidade de volatilização, tendo sido anotados o local e a data de coleta.

As análises físico-químicas e bacteriológicas foram realizadas nos mesmos dias da coleta no Laboratório de Controle da Qualidade de Água da CAESB, o principal laboratório de análise de água do DF. O ion sulfato como não faz parte da rotina daquele laboratório, teve sua análise realizada no Laboratório de Análises de Solo e Água do Centro de Pesquisa Agropecuária do Cerrado (CPAC - EMBRAPA), sendo as amostras mantidas refrigeradas em frascos de polietileno a $4^{\circ} \mathrm{C}$.

A determinação de coliformes totais e fecais foi realizada através do método de fermentação em tubos múltiplos. As técnicas analíticas empregadas na análise dos parâmetros físico-químicos nos laboratórios seguiram metodologia descrita no "Standard Methods for the Examination of Water and Wastewater" (APHA 1985). 


\section{Caracterização da Área de Estudo}

\subsection{ASPECTOS DE USO E OCUPAÇÃo do SOLO}

A cidade de Sobradinho foi fundada em 13 de maio de 1960 para abrigar a população que vivia nas firmas empreiteiras na Vila Amauri e, principalmente, funcionários públicos. Neste periodo, sua Região Administrativa (RA), que possui uma área de $571 \mathrm{~km}^{2}$, apresentava uma população de 8.478 habitantes, que chegou a 81.354 em 1991 (IBGE 1991). Em 1991, 83,8\% da população estava concentrada em área urbana.

É importante ressaltar que, embora definidos como rurais, as áreas de loteamentos e condominios da região, na verdade se constituem como núcleos urbanos ou semi-urbanos. Ou seja, a maior parte da população da RA de Sobradinho considerada como da área rural no levantamento do IBGE, ocupa na verdade áreas com características de zona urbana.

A cidade de Sobradinho e o assentamento Sobradinho II são abastecidas pelas captações dos córregos Contagem, Paranoazinho e Corguinho. O consumo per capita dessas cidades é de 250 L/hab.dia (CAESB 1995 apud IPDF 1996) para uma população atendida estimada em 74.000 pessoas (CAESB 1998). Os esgotos destas cidades são tratados e lançados no ribeirão Sobradinho.

O assentamento Sobradinho II apresenta uma população estimada de 27.000 habitantes e até 1997 foi abastecida através de cinco poços tubulares. Com a construção de uma adutora a partir de Sobradinho, os poços foram desativados e a água subterrânea substituída pela superficial.

O parcelamento e o desmembramento de áreas rurais são as principais características da região, uma vez que não existe um controle sobre o uso e ocupação do solo. A dinâmica populacional na área vem sendo marcada, a partir da década de 80 e com mais intensidade na de 90 , pelo processo de ocupação movido pela demanda habitacional que se realiza através dos condomínios e loteamentos em zonas rurais. Este processo resultou na criação do assentamento de Sobradinho II.

A sul da cidade de Sobradinho, ao longo da BR-020, está localizado o limite norte da Área de Proteção Ambiental (APA) do rio São Bartolomeu, criada em 1983 com o objetivo de proteger os recursos hídricos da região, principalmente o rio São Bartolomeu, considerado manancial estratégico para o abastecimento futuro de água no DF.

Com a grande proliferação de loteamentos irregulares, geralmente sob a forma de condomínios, foi realizado o estudo de rezoneamento da APA (ENGEVIX 1994). Os resultados indicavam possibilidades de ocupação para fins urbanos no interior da APA, abrindo caminho para o atual processo de regularização de parte dos loteamentos. $\mathrm{Na}$ RA 
de Sobradinho em 1996 existia um total de 75 parcelamentos do solo em processo de regularização (GDF 1996).

A atividade industrial é pouco significativa na área. As indústrias de cimento Tocantins e CIPLAN constituem o segmento básico da indústria de Sobradinho (ENGEVIX 1994), estão localizadas a norte da área de estudo, e exploram as rochas calcárias do Grupo Paranoá.

A área rural da região de Sobradinho é dividida administrativamente nos núcleos rurais Sobradinho I (NRSI) e Sobradinho II (NRSII), nos quais predomina amplamente a pequena propriedade.

O NRSII localizamse na região a norte da BR-020 e apresenta atualmente características de ocupação urbana e semi-urbana, com a presença do assentamento de Sobradinho II e a maior concentração de lotes e condomínios na área de estudo. Estes loteamentos sob a forma de condomínios ou simples desmembramentos não possuem, em geral, infra-estrutura sanitária e o abastecimento é realizado, na sua grande maioria, através de poços tubulares profundos. Apenas a porção norte, adjacente à cidade de Sobradinho, ainda apresenta características rurais, predominando a pecuária de leite e corte e a presença de 3 criadores de cavalos e um caprinocultor (ENGEVIX 1994).

O NRSI localiza-se ao sul da cidade de Sobradinho, inclui-se inteiramente no território da APA do rio São Bartolomeu, e compreende 60 produtores, cuja principal atividade produção é a pecuária bovina de leite e corte e, subordinadamente, a criação de suinos e aves e plantio de milho, hortaliças e frutas (ENGEVIX 1994). Apesar de apresentar uma ocupação de caráter rural, o processo de parcelamento do solo com a formação de pequenos núcleos semi-urbanos já é bastante importante ao longo da BR-020 e da DF-250. Esta ocupação tem se dado principalmente nas porções mais elevadas da bacia, na região de chapada, no qual a topografia é plana. $O$ abastecimento de água é proveniente de poços rasos (cacimbas), minas (nascentes), alguns poços profundos e pequenos córregos.

A área de estudo se caracteriza também pela existência de extensa área localizada na região leste da bacia de Sobradinho pertencente ao CPAC/EMBRAPA. Nas regiões oeste e norte da de bacia, nas partes mais elevadas, existem áreas de reflorestamento com pinheiros.

$\mathrm{Na}$ área de estudo em relação à vegetação nativa remanescente predominam os campos de cerrado, seguidos de florestas galeria e vegetação hidrófila (ENGEVIX 1994). Estas variações que gradam desde fisionomias mais abertas, de campo, até mais fechadas, florestais, são típicas da vegetação de cerrado.

Os campos de cerrado ocupam grande parte das encostas do vale do ribeirão Sobradinho e são freqüentemente utilizados como pasto nativo para pecuária. São poucas as áreas remanescentes de cerrado, sendo as mais significativas a região do CPAC e da 
captação do córrego Paranoazinho da CAESB, na qual os cerradões bastante raros podem ser observados. As florestas galeria úmidas ocorrem nas áreas mais planas, acompanhando principalmente os córregos e ribeirões da área, destacando-se aquelas que margeiam o ribeirão Sobradinho. A vegetação hidrófila ocorre em ambientes úmidos acompanhando as matas galeria nas regiões mais planas. Destacam-se as veredas que ocorrem na cabeceira do ribeirão Sobradinho e os campos úmidos e brejos que acompanham esse ribeirão e alguns de seus afluentes. Os campos de murundus também estão presentes em porções localizadas, como na área da captação do córrego Paranoazinho.

\subsection{GEOMORFOLOGIA}

O DF está situado no Planalto Central e apresenta como elemento marcante na sua paisagem as chapadas, extensas superficies de relevo plano a suave ondulado, intercaladas por niveis arrasados. As cotas altimétricas do DF ficam entre 750 e $1336 \mathrm{~m}$, sendo que cerca de $57 \%$ está acima da cota de $1.000 \mathrm{~m}$ (Novaes Pinto 1987). As formas de relevo do DF resultam da atuação de diversos fatores, entre os quais se destacam os paleoclimáticos, litológicos, tectônicos e edáficos.

As terras altas do DF apresentam-se como dispersoras de águas para as bacias de drenagem do rio Maranhão (bacia Amazônica), do rio Preto (bacia do São Francisco), e dos rios São Bartolomeu e Descoberto e ribeirão Ponte Alta (bacia Platina) (Novaes Pinto 1986b). Embora os divisores de águas se caracterizem, de modo geral, pelas suas amplitudes, há exemplos que interrompem a morfologia. $\mathrm{Na}$ área de estudo como exemplo, o ribeirão Sobradinho tem suas nascentes próximas às de um formador do córrego Corguinho, que também se dirige para o rio São Bartolomeu. Este ribeirão encontra-se ameaçado pela erosão regressiva acelerada do córrego Sansão e pela erosão nas cabeceiras do ribeirão Contagem, tributários do rio Maranhão (Novaes Pinto 1986b).

O DF conta com um número significativo de estudos sobre geomorfologia, que reconhecem basicamente três grandes compartimentos ou paisagens geomorfológicas, que recebem diferentes denominações.

Penteado (1976) relacionou os diferentes depósitos de concreções ferruginosas com os compartimentos geomorfológicos da região de Brasília, classificando as superfícies em Pediplano da Contagem e pontos culminantes do Morro da Canastra (1200-1300 m), Pediplano de Brasília (1000-1100 m) e uma superficie de pediplanação mais baixa de idade plio-pleistocênica. A EMBRAPA (1978) define três superfícies de aplainamento: a primeira e mais antiga é denominada de Superfície Cretácica Inferior (1300 a $1150 \mathrm{~m}$ ), a Superfície Cretácica Média (1150 a 1000 m) e uma terceira superfície de cotas entre 1000 e $800 \mathrm{~m}$. 
Novaes Pinto (1987) analisando os elementos da paisagem do DF identifica a Região das Chapadas com três niveis disitintos (> 1200 m; 1100 m; 1000 m), a Região Corrugada dos Vales dos rios Descoberto, São Bartolomeu e Maranhão, e as Áreas de Dissecação Intermediária da Depressão do Paranoá e Vale do Rio Preto. Novaes Pinto (1986a) define três macrounidades: Região de Chapada, Área de Dissecação Intermediária e Região Dissecada de Vales, subdivididas em 13 unidades geomorfológicas.

A área de estudo se insere em dois grandes compartimentos geomorfológicos denominados de Chapadas e Vales Dissecados (Novaes Pinto 1986a, 1994a) (figura 2). O trecho no qual o ribeirão Sobradinho apresenta direção NW corresponde à unidade da Chapada da Contagem. O curso inferior deste ribeirão, de direção E-W, é classificado como região de Vale Dissecado do Alto Curso do rio São Bartolomeu.

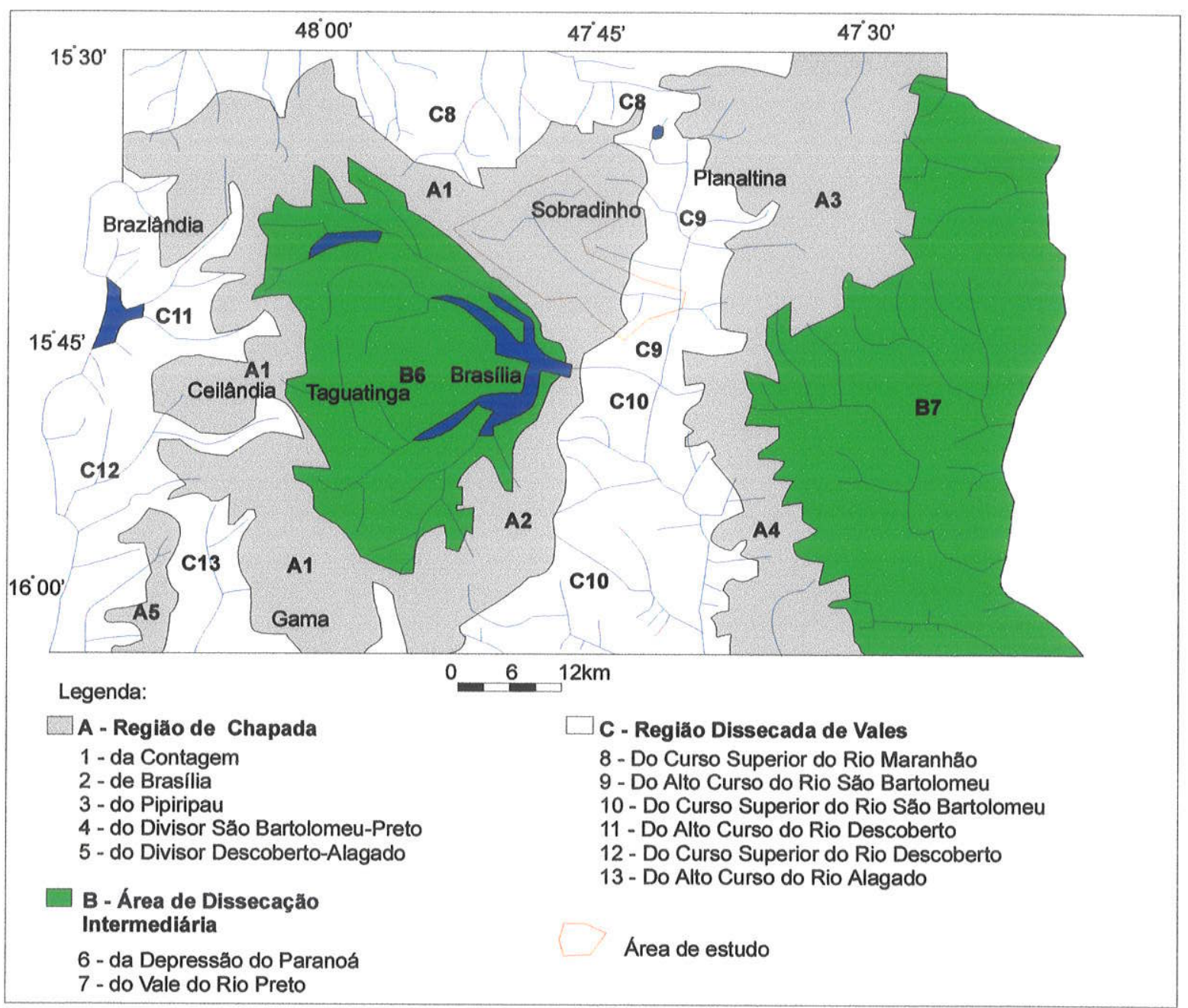

Figura 2. Mapa geomorfológico do Distrito Federal (Novaes Pinto 1986) com a localização da área de estudo.

A Chapada da Contagem é a unidade geomorfológica mais elevada do DF, em cotas médias de $1.200 \mathrm{~m}$, que se estende desde o Morro da Canastra, a norte da cidade de 
Sobradinho, até a cidade do Gama, a sudoeste do DF. Nela está localizado o ponto mais elevado do DF, o Rodeador $(1336 \mathrm{~m})$. A área funciona como divisora de águas que fluem para a bacia Amazônica, através da drenagem de sub-bacias da margem esquerda do rio Maranhão a norte e aquelas que escoam para a bacia Platina, por meio das sub-bacias do ribeirão Sobradinho e do rio Paranoá, ambos tributários do rio São Bartolomeu (Novaes Pinto 1986a). Esta unidade geomorfológica apresenta topografia plana a plana ondulada, associada a lombadas e encostas retilineas com declividades inferiores a $8 \%$ (Novaes Pinto 1986a, 1994a).

A paisagem Dissecada de Vales do Alto Curso do rio São Bartolomeu inclui as cabeceiras dos formadores do rio São Bartolomeu, e se estende até a confluência do rio Paranoá (Novaes Pinto 1986a). O contato com as chapadas se faz por meio de encostas íngremes, com aclives que vão de 5 a $20 \%$, e algumas vezes acima de $20 \%$, como é o caso da cachoeira do Gancho, localizada no ribeirão Sobradinho, que marca a passagem da chapada para esta unidade. Próximo à confluência do Sobradinho com o rio São Bartolomeu, as classes de declividades variam entre 10 e $20 \%$ e maiores que $20 \%$, as encostas são convexo-côncavas, os vales profundos em $\mathrm{V}$ e rebordos de dissecação (Novaes Pinto 1994b). Esta unidade é formada pelo entalhamento de um pediplano pliopleistocênico embutido no vale, apresentando lombadas e inselbergues, com pedimentos que se espalham pela área da unidade tanto no sopé dos inselbergues, como na base das chapadas. Concreções ferruginosas cobrem as encostas e os pedimentos (Novaes Pinto 1986a).

Os primeiros estudos consideraram a origem das chapadas do DF como relacionada aos processos de pediplanação (Penteado 1976, EMBRAPA 1978) conforme o conceito de King (1956). Elas seriam portanto, remanescentes de aplainamentos dos ciclos de erosão Sul-americano e Velhas que desenvolveram-se no Terciário.

Outros trabalhos adotam a teoria da etchiplanação (Novaes Pinto 1986a, 1986b, 1987, Novaes Pinto 1994a). A etchiplanação é o processo de aplainamento de regiões tropicais semi-úmidas, que provoca o rebaixamento topográfico pela retirada parcial ou total do regolito com o conseqüente afloramento do substrato rochoso, ou seja, da antiga frente de intemperismo (Novaes Pinto 1986a). As chapadas, segundo a teoria da etchiplanação, são interpretadas como residuais de aplainamentos cenozóicos durante o Terciário sobre rochas quartzíticas (chapadas da Contagem, Brasilia e Pipiripau) e rochas como ardósias, filitos e micaxistos (chapadas divisoras São Bartolomeu-Preto e Descoberto-Alagado), sob condições de clima semitropical. Posteriormente, os etchiplanos foram remodelados por processos de pedimentação e pediplanização, iniciados no Plioceno, associados a reativações tectônicas e variações climáticas pleistocênicas, que propiciaram a dissecação 
dos vales em intensidades variadas e formação dos pedimentos e pediplanos (Novaes Pinto 1987, 1994a).

\subsection{GEOLOGIA}

\subsubsection{CONTEXTO GEOLÓGICO REGIONAL}

A Província Tocantins (Almeida et al. 1977) compreende todos os terrenos situados entre os crátons Amazônico e São Francisco. Na porção oriental da provincia está situada a Faixa Brasília (FB), originalmente denominada Geossinclíneo Brasília (Almeida 1967), que acompanha a margem oeste do Cráton do São Francisco e se estende por mais de 1.000 km na direção N-S, ocupando parte dos estados de Minas Gerais, Goiás, Tocantins e englobando o DF. A FB constitui extensa zona de dobramentos composta por terrenos de sua infra-estrutura e supracrustais do Meso a Neoproterozóico, cuja deformação e metamorfismo são relacionados ao Ciclo Brasiliano, de idade neoproterozóica.

Existe controvérsia na definição do limite ocidental da FB, quanto à inclusão dos metassedimentos pertencentes aos grupos Serra da Mesa e Araxá. Almeida (1967) considera as estruturas Araxaídes como pertencentes à Faixa Uruaçu, desenvolvidas no ciclo orogênico Uruaçuano (1.000 a $1.200 \mathrm{Ma}$ ). Fuck (1990) baseado em dados isotópicos e estruturais demonstra que os grupos Araxá, Canastra e Serra de Mesa apresentam evolução tectônica brasiliana representando portanto, unidades mais internas da FB, o que já havia sido sugerido por Dardenne (1978b). Desta forma, tem sido adotada a definição de FB como sendo limitada a oeste pelo Maciço Mediano de Goiás e o Arco Magmático, e a leste pelo Cráton do São Francisco (Fuck 1990, 1994, Fuck et al. 1994) (figura 3).

No conjunto a FB exibe uma nitida polaridade tectônica, sedimentar e metamórfica no sentido oeste-leste, com vergência geral em direção ao Cráton do São Francisco. Importante feição tectônica regional é a Megaflexura dos Pirineus (Costa \& Angeiras 1971), que ocorre na altura do paralelo de Brasília e que permite dividir a faixa em duas porções (Fuck \& Marini 1979). A norte da flexura as direções estruturais são predominantemente NE, enquanto que a sul elas são NW. Os efeitos da megainflexão dos Pirineus abrandam-se para E, sendo que a leste do DF tornam-se inconspicuos (Almeida \& Hasui 1984).

São distinguidas na FB as seguintes zonas (Fuck 1994, Fuck et al. 1994):

$>$ zona cratônica, que é representada por algumas exposições do embasamento e por coberturas fanerozóicas e pré-cambrianas, cuja deformação, quando existente, é de caráter epidérmico; 


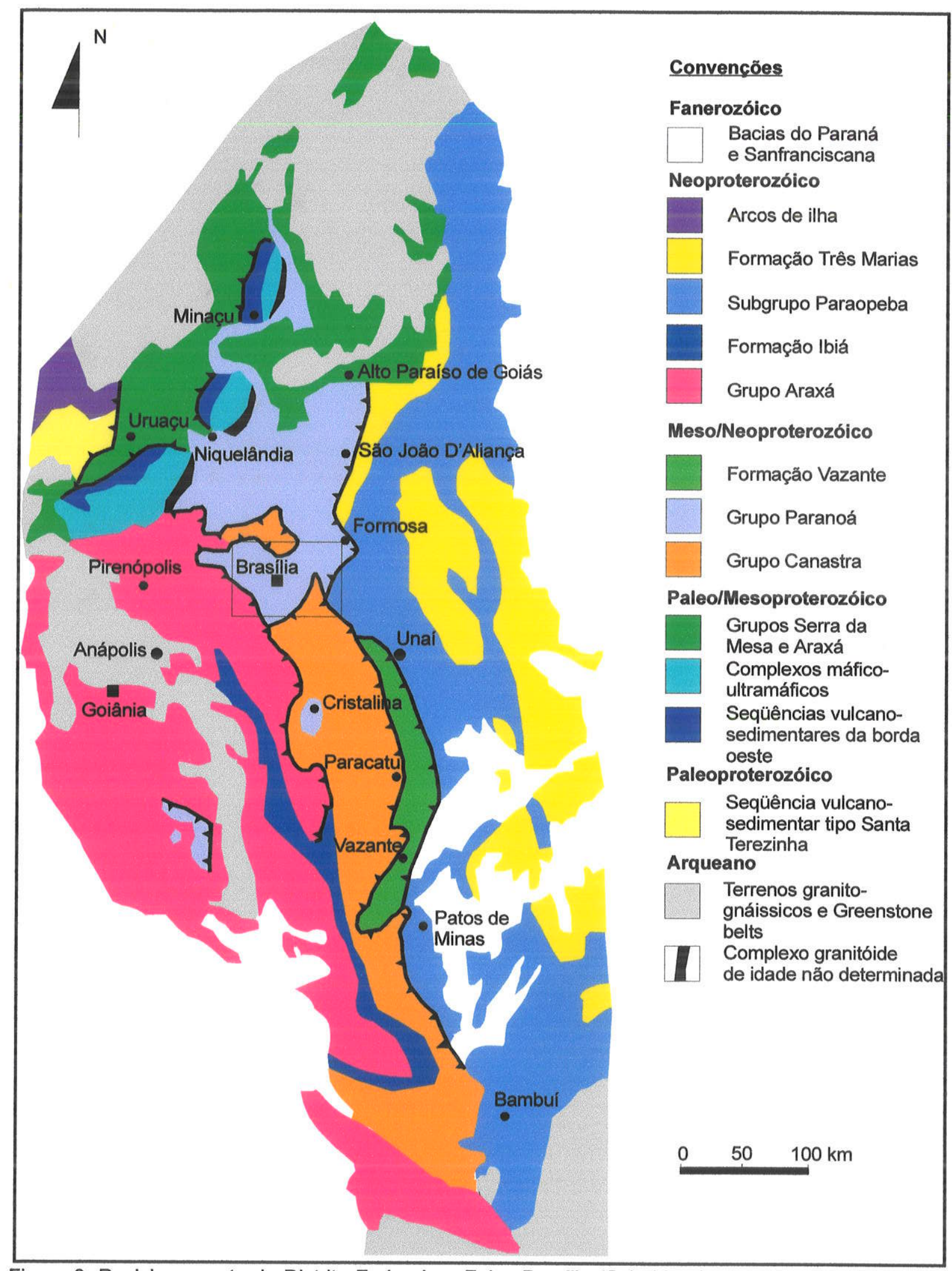

Figura 3. Posicionamento do Distrito Federal na Faixa Brasília (Schobbenhaus et al. 1981apud Fuck et al. 1992). 
$>$ zona externa, composta pelas unidades metassedimentares dos grupos Paranoá, Bambuí e Canastra e formações Vazante e Ibiá, estruturadas em um cinturão de dobras e falhas de antepaís;

zona interna, representada por unidades dos grupos Araí, Serra da Mesa e Araxá e porções do embasamento tectonicamente posicionadas entre as faixas de xistos.

$O$ DF se insere na transição entre as zonas externa e interna da FB, tendo sido reconhecidas rochas pertencentes aos Grupos Canastra, Araxá, Paranoá e Bambuí (figura $3)$.

Os primeiros estudos geológicos que englobaram a região do DF foram executados em uma área ampla com cerca de $50.000 \mathrm{~km}^{2}$ e fizeram parte de estudo técnico para a construção da nova capital do país, o denominado Relatório Belcher (Belcher 1954). O primeiro trabalho de mapeamento de caráter regional e sistemático abrangendo a região identificou as séries Araxá, Canastra, Bambuí, "Formação das Chapadas" (Terciário) e os aluviões (Quaternário) (Barbosa 1961). Na Série Bambuí, foram identificadas as formações Torto, Paranoá e Indaiá. Ramos (1956) já havia denominado os quartzitos de Brasilia de Formação Paranauá e as ardósias de Formação Torto, correlacionando-as com a Série Bambuí.

Na década de 70 as referências mais importantes sobre a geologia do DF fazem parte do roteiro de excursões do Congresso Brasileiro de Geologia de 1970. A litoestratigrafia detalhada do DF foi apresentada por Faria (1989), que caracterizou os grupos Paranoá e Canastra. Uma limitação quanto à estratigrafia proposta para o DF e, em especial, dos mapas geológicos (Faria 1988, 1995), é a presença de uma extensa cobertura detritico-laterítica que chega a recobrir quase $60 \%$ da área. Freitas-Silva \& Campos (1998) apresentaram uma nova estratigrafia, retirando do mapa geológico estas coberturas (figura 4). Nessa nova concepção foram incluídos o Grupo Araxá no extremo sudoeste do DF, antes considerado como micaxistos do Grupo Canastra (Faria 1985, 1995), e o Grupo Bambui na borda leste, anteriormente interpretado como pertencente à unidade de topo do Grupo Paranoá (Faria 1989, 1995). A estratigrafia do DF apresentada a seguir é baseada no estudo de Freitas-Silva \& Campos (1998).

- Grupo Araxá tem sua ocorrência restrita a região sudoeste do DF, que corresponde a $5 \%$ de sua área total, sendo composto essencialmente por xistos variados (muscovita-quartzo xistos, quartzo xistos, clorita-muscovita xistos) e subordinadamente, por quartzitos na forma de bancos decimétricos ou lentes de dezenas de metros.

O Grupo Bambuí ocorre na região leste do DF, ao longo de todo o vale do rio Preto desde o ribeirão Santa Rita (afluente da margem direita do rio Preto). É constituído por uma seqüência essencialmente pelítica, composta por metargilitos, metafolhelhos e metassiltitos argilosos, sendo localmente observados bancos de arcóseos e siltitos. Estas litologias 


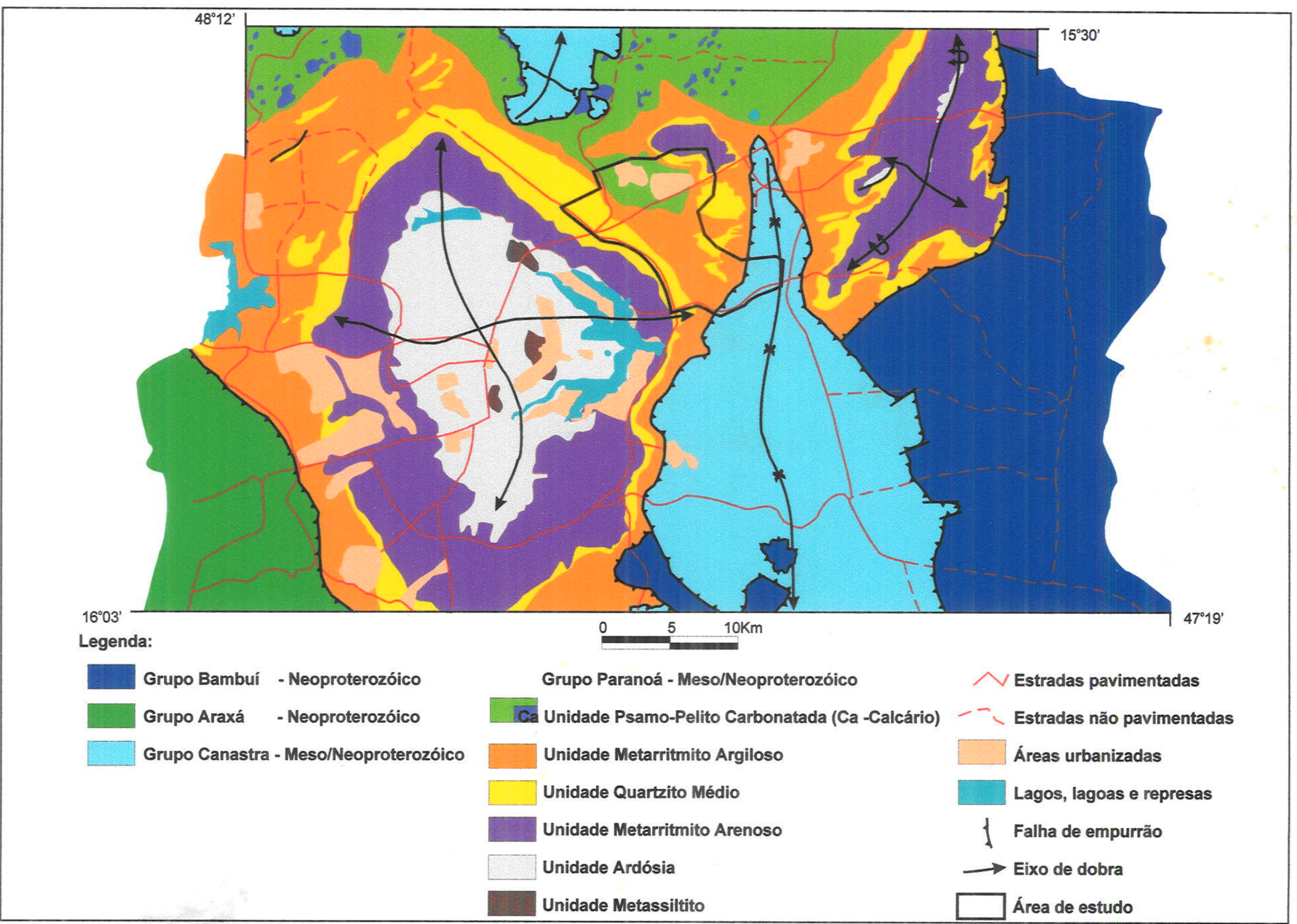

Figura 4. Mapa geológico do Distrito Federal ( Freitas-Silva \& Campos 1998). 
podem ser correlacionadas à unidade pelitica do topo do Subgrupo Paraopeba (Formação Serra da Saudade) e com a base da Formação Três Marias (Freitas-Silva \& Campos 1998).

O Grupo Paranoá é a unidade de mais ampla distribuição no DF ocupando cerca de $65 \%$ da área do DF. O Grupo Canastra ocupa cerca de $15 \%$ e ocorre nos vales dos rios São Bartolomeu (porção centro-leste) e rio Maranhão (porção meio-norte). Será apresentado, a seguir, um maior detalhamento da litoestratigrafia destes grupos em função da sua importância no DF, e também por terem sido reconhecidas na área de estudo litologias pertencentes a estas unidades (figura 4).

\subsubsection{GEOLOGIA dA ÁREA DE ESTUdo}

\section{- Grupo paranoá}

Os sedimentos detríticos da Formação Paranoá foram considerados formação inferior do Grupo Bambui (Braun 1968, Barbosa et al. 1969). Dardenne (1978a, 1979) propôs a individualização do Grupo Paranoá, situado estratigraficamente acima do Grupo Araí e abaixo do Bambuí. Esta separação já havia sido proposta em estudos pioneiros como Oliveira (1967).

Dardenne \& Faria (1985) escolheram a área de Alto Paraiso de Golás como seção tipo, definindo nove litofácies com predomínio de psamitos na parte basal e tipos pelitocarbonatados no topo. Faria (1995) mostrou que esta estava incompleta, pois omitia a parte superior da seqüência exposta na área de São João D'Aliança - São Gabriel (Goiás). A seqüência passa a ser composta por doze litofácies com status de formações indicativas de ambiente marinho. Ela inicia-se com o paraconglomerado São Miguel (SM) e segue com metarritmito $\left(R_{1}\right)$, quartzito fino a médio $\left(Q_{1}\right)$, metarritmito $\left(R_{2}\right)$, quartzito microconglomerático $\left(Q_{2}\right)$, metassiltito argiloso $(S)$, ardósia $(A)$, metarritmito arenoso $\left(R_{3}\right)$, quarzito médio $\left(Q_{3}\right)$, metarritmito argiloso $\left(R_{4}\right)$, quartzito feldspático $\left(Q_{4}\right)$ e pelito-carbonatada (PC). O Grupo Paranoá representa uma megasseqüência deposicional marinha rasa predominantemente transgressiva, correspondendo a um periodo de prolongada quiescência tectônica (Faria 1995).

As idades de deposição do Grupo Paranoá são baseadas em estudos paleontológicos de estromatólitos. Cloud \& Dardenne (1973) e Dardenne \& Campos Neto (1976) interpretaram os estromatólitos como pertencentes ao Grupo Bambui, atribuindo uma idade compreendida entre 1.350 e $950 \mathrm{Ma}$. Posteriormente, Dardenne (1978a, 1979) reinterpretando a litoestratigrafia Paranoá-Bambuí, posicionou os estromatólitos dentro do Grupo Paranoá confirmando este intervalo de idade.

No DF, Faria (1989) subdividiu o Grupo Paranoá em 5 unidades deposicionais denominadas da base para o topo de ardósia (A), metarritmito inferior arenoso $(B)$, quartzito 
(C), metarritmito superior argiloso (D) e argilo-carbonatada (E). Faria (1995) acrescentou a esta seqüência a unidade basal, denominada de quartzito microconglomerático. No DF, a estratigrafia proposta por Freitas-Silva \& Campos (1998) apresenta, para o Grupo Paranoá, um maior detalhamento da seqüência litológica em relação a Faria (1995). A diferença mais significativa entre estes trabalhos é que a unidade basal, representada por um quartzito microconglomerático (Faria 1995), foi retirada por Freitas-Silva \& Campos (1998).

A estratigrafia do Grupo Paranoá é representada por seis unidades que, da base para o topo, são $S, A, R_{3}, Q_{3}, R_{4}$ e PPC (figura 5). As espessuras destas unidades não foram estimadas no DF, sendo consideradas aquelas obtidas nas áreas-tipo: $S$ até $500 \mathrm{~m} ; A$ aproximadamente $70 \mathrm{~m} ; R_{3}$ de $100 \mathrm{~m} ; Q_{3}$ de $70 \mathrm{~m} ; R_{4}$ de 100 a $150 \mathrm{~m}$ e PPC de 120 a 150 m (Freitas-Silva \& Campos 1998). Na área de estudo ocorrem litologias pertencentes às unidades de topo $R_{3}, Q_{3}, R_{4}$ e PPC.

A estratigrafia do Grupo Paranoá no DF (figura 5) se inicia pela unidade Metassiltito Argiloso (S), que é composta essencialmente por um conjunto de metassiltitos argilosos homogêneos, aos quais se intercalam na base (subunidade $S_{a}$ ) niveis de quartzito fino de espessura desde centimétricas a decimétricas e no topo, (subunidade $S_{c}$ ) bancos de quartzitos arcoseanos decimétricos e ocasionais lentes carbonáticas interdigitadas. A litofácies intermediária (subunidade $S_{b}$ ) é composta por um conjunto bastante homogêneo de metassiltitos argilosos.

Em seguida, vem a unidade Ardósia (A) que é caracterizada por ardósias roxas, quando alteradas, ou cinza esverdeadas, quando frescas. Próximo ao limite com a unidade superior, começam a aparecer intercalações síltico-argilosas milimétricas a centimétricas, na qual se inicia a passagem gradacional para a unidade que a recobre. As ocorrências de quartzitos são raras e se caracterizam por lentes métricas ou decamétricas, geralmente irregulares e maciças.

A unidade Metarritmito Arenoso $\left(R_{3}\right)$ é caracterizada pela alternância de estratos centimétricos a métricos de quartzitos finos a médios, com níveis geralmente mais delgados de metassiltitos argilosos, metalamitos siltosos e metalamitos micáceos. No DF, esta unidade foi subdividida em duas subunidades, que são da base para o topo:

$>$ Subunidade $\mathrm{R}_{3 \mathrm{a}}$ : inicia-se por um pacote de metassiltitos argilosos, no qual os niveis de metalamitos são freqüentes em direção ao topo. A medida que os niveis metapelíticos se tornam cada vez mais raros até desaparecem, aumentam os níveis quartzíticos que formam intercalações milimétricas a métricas, passando a predominar no topo da seção que termina com um nivel espesso de quartzito denominado de $q_{1}$. Este quartzito $q_{1}$ apresenta caráter lenticular, granulação fina a média e espessura variável entre 8 e $20 \mathrm{~m}$; 
Unidade Psamo-Pelito-Carbonatada: conjunto de metargilitos e metassiltitos argilosos intensamente dobrado, associado a lentes de metacalcários variados e raras lentes de dolomitos (dezenas de metros de diâmetro). Ocorrên. cia comum de níveis e lentes de quartzitos pretos, grossos a conglomeráticos, em níveis contínuos ou na forma lenticular.

Unidade Metarritmito Argiloso: intercalações regulares de quartzitos finos e metassiltitos argilosos com raros bancos de quartzitos médios $\mathbf{R}_{\mathbf{4}}=\ldots$. $=$ decimétricos.

Unidade Quartzito Médio: quartzitos brancos, maciços ou estratificados em pacotes métricos, silicificados, com intercalações métricas de metarritmitos próximo à base e ao topo.

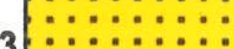

$=\div-$

..............

………

$-\cdots+\infty$

$\because \because: \because \because: \because$

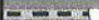

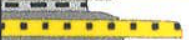

$\mathbf{R}_{3} \therefore \therefore ; \ldots$

Unidade Metarritmito Arenoso: intercalações de bancos de quartzi-

tos, metassiltitos e metargilitos. Dois pacotes de até 12 metros de

$=-7 \div \ldots$ espessura são individualizados nas porções inferior e superior da seqüência.

$-2=2 \cdots$

$\cdots \cdots$

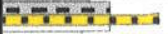

$\ldots \ldots$

$\cdots \cdots$

$2=2$
A

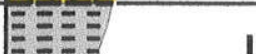

Unidade Ardósia: ardósias roxas (cinza quando frescas), homogêneas e com metassiltitos no topo, associadas a raras lentes de quartzitos maciços.

\section{Unidade Metassiltito}

Sc - Subunidade Metarritmito: intercalações de níveis quartzíticos decimétricos com material metapelítico e raras lentes de metacalcários.

$\mathrm{Sb}$ - Subunidade Metassiltito: metassiltitos argilosos cinza esverdeados, maciços.

Sc - Subunidade Metarritmito Basal: bancos decimétricos a métricos

.... de quartzitos médios e metassiltitos.

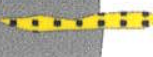

A S AF AM

Figura 5. Coluna litoestratigráfica do Grupo Paranoá no Distrito Federal (Freitas-Silva \& Campos 1998). Na área de estudo ocorrem as unidades $R_{3}, Q_{3}, R_{4}$ e PPC. 
Subunidade $R_{3 b}$ : inicia-se por contato gradacional sobre o quartzito $q_{1}$, com metassiltitos que passam para uma seqüência tipicamente rítmica na qual intercalam-se estratos desde argilosos até arenosos de 1 a $5 \mathrm{~cm}$ de espessura. $O$ acunhamento lateral e 0 aspecto lenticular de alguns estratos são feições comuns. Os termos mais arenosos se tornam mais importantes em direção ao topo desta subunidade, onde passam a dominar sobre os metapelíticos, culminando com outro nivel de quartzito com espessura variando entre 5 e 15 $m$ e granulação fina a média, denominado de quartzito $q_{2}$.

A unidade Quartzitos Médios $\left(Q_{3}\right)$ apresenta contato brusco e concordante com a unidade sotoposta. É composta por quartzitos finos a médios muito localmente grossos, bem selecionados, em geral, muito silicificados. Lentes de metarritmitos com espessura decimétricas de até $10 \mathrm{~m}$ ocorrem geralmente próximas a base e ao topo.

A unidade Metarritmito Argiloso $\left(R_{4}\right)$ é formada por um metarritmito homogêneo com intercalações centimétricas regulares de metassiltitos, metalamitos e quartzitos finos. Localmente ocorrem níveis $(50 \mathrm{~cm}$ até $1 \mathrm{~m}$ ) de metassiltitos maciços e quartzitos finos feldspáticos. Seu contato com a unidade $Q_{3}$ é gradacional.

A unidade Psamo-Pelito-Carbonatada (PPC) corresponde à Pelito-Carbonatada de Faria (1995), mas em função da constante presença de niveis de quartzito, é proposta esta nova denominação (Freitas-Silva \& Campos 1998). Esta unidade apresenta contato transicional com a $\mathbf{R}_{4}$, sendo composta por metalamitos siltosos bastante laminados $\mathrm{e}$ intercalações de rochas quartzítcas e carbonáticas. As rochas carbonáticas são representadas por calcários e subordinadamente, por dolomitos localmente estromatolíticos, que ocorrem como lentes de centenas de metros, podendo alcançar mais de um quilômetro. $\mathrm{Na}$ região de interdigitação entre as lentes carbonáticas e as rochas pelíticas, são comuns as fácies de metamargas. Ocorrem ainda, lentes métricas a decamétricas ou em niveis centimétricos de quartzitos médios, grossos a conglomeráticos, que podem apresentar certa ritmicidade.

\section{- Grupo Canastra}

De acordo com a definição original, Barbosa (1955) caracterizou a "Série" Araxá, dividindo-a nas formações Araxá e Canastra, separadas por provável discordância angular. Barbosa (1970) deu a essas formações o status de grupo. Trabalhos posteriores evidenciaram a dificuldade de separar as duas unidades e a existência de discordância foi contestada. Os grupos Canastra e Araxá têm sido considerados unidades transicionais que caracterizam um único ciclo sedimentar, embora com características sedimentológicas indicadoras de ambientes distintos (Teixeira \& Danni 1978), tendo sido identificados contatos do tipo gradacional entre estas unidades (Heilbron et al. 1987, Valeriano et al. 
1989). Fuck \& Marini (1981) consideram os grupos Serra da Mesa, Araí e Canastra homotaxiais ao Grupo Araxá, ou seja, aproximadamente síncronos.

Freitas-Silva \& Dardenne (1994) fizeram a primeira proposição formal da estratigrafia para o Grupo Canastra, identificando 4 unidades de caráter regional. A seqüência é composta por quartzo-sericita filitos carbonosos com intercalações subordinadas de quartzitos e quartzo- sericita-clorita filitos (Formação Morro do Ouro), quartzo-sericita-clorita filitos com intercalações subordinadas de filitos carbonosos, quartzitos e metassiltitos (Formação Serra da Anta), quartzo-sericita-clorita filitos intercalados com quartzitos e metassiltitos (Formação Serra da Ucrânia) e ortoquartzitos com intercalações subordinadas de quartzitos (Formação Serra da Batalha). As duas unidades inferiores correspondem ao Subgrupo Paracatu e as superiores ao Subgrupo Chapada dos Pilões.

No DF o Grupo Canastra foi subdividido em três unidades denominadas da base para o topo de micaxisto (A), calcixisto (B) e filito (C) (Faria 1989, 1995). Os xistos pertencentes às unidades $\mathrm{A}$ e $\mathrm{B}$ foram posteriormente, posicionados dentro do Grupo Araxá. A unidade no DF passa a ser caracterizada por um conjunto amplamente dominado por filitos variados (clorita filitos, quartzo-sericita-clorita filitos, sericita filitos) com contribuição restrita de quartzitos, calcifilitos, mármores e filitos carbonosos (Freitas-Silva \& Campos 1998). O Grupo Canastra ocorre de forma restrita na área de estudo, próximo à confluência do ribeirão Sobradinho com o rio São Bartolomeu.

\subsubsection{ARCABOUÇo EstrutuRAL. Do Distrito FEDERAL}

A primeira referência sobre a geologia estrutural do DF aparece no estudo regional realizado por Barbosa (1963). Ladeira \& Salomão (1970) foram os primeiros a destacar a estruturação semi-dômica da região, constituindo um anticlinório com eixo com caimento geral para E-SE. Ramos (1956) já havia observado com base nas características geomorfológicas da região e do padrão de drenagem, que a capital estava localizada sobre a cúpola de um domo.

O conhecimento atual revela que a deformação está relacionada à deformação tectônica Brasiliana que afetou o conjunto da zona externa da Faixa Brasilia, por volta de $650 \mathrm{Ma}$.

Araújo Fitho \& Faria (1992) e Faria (1995) caracterizam no DF dois eventos deformacionais. O primeiro evento representa uma compressão com transporte tectônico de $W$ para $E$, formando um sistema de leques imbricados, a que estão associadas estruturas dobradas. O segundo evento deformacional está associado a uma cinemática N-S de caráter compressivo, menos intenso que o anterior, que aproveita as rampas e planos tectônicos anteriores como superficies mecânicas de propagação (Araújo Filho \& Faria 
1992). Freitas-Silva et al. (1994) e Freitas-Silva \& Campos (1998) identificam diferentes fases de deformação que refletem a progressão de um único evento.

Os dados disponiveis sobre a geometria e cinemática da Faixa Brasilia indicam que o modelo de deformação progressiva (Freitas-Silva et al. 1994, Freitas-Silva \& Campos 1998) é mais adequado do que aquele de dois eventos (Araújo Filho \& Faria 1992, Faria 1995). A compressão W-E já está bem caracterizada na região, enquanto que o possível evento N-S não apresenta compatibilidade cinemática com a estruturação geral da FB na área do DF. Neste caso, os padrões de interferência de dobras ao qual estaria relacionado o evento deformacional N-S (Araújo Filho \& Faria 1992, Faria 1995), são relacionados ao tensor intermediário de deformação aproximadamente constante (deformação plana), que passa a se comportar nas fases mais avançadas como um eixo de encurtamento, levando a deformação para o campo constriccional (Freitas-Silva \& Campos 1998).

A mega-estruturação do DF é condicionada pelo padrão de interferência dos dobramentos (Faria 1995, Freitas-Silva \& Campos 1998), cujos principais exemplos são os domos estruturais do Brasília, do Pipiripau e de Sobradinho, e pelo arranjo e cronologia relativa de três grandes sistemas de cavalgamento denominados de Paranã, São Bartolomeu/Maranhão e Descoberto (Freitas-Silva \& Campos 1998). Foram identificadas cinco fases de deformação denominadas de $F_{1}$ a $F_{5}$. Com exceção da última fase $\left(F_{5}\right)$, de caráter eminentemente rúptil, as demais são caracterizadas por estruturas dúcteis-rúpteis representadas por planos de cavalgamento e dobramentos (Freitas-Silva \& Campos 1998).

\section{- Estruturas Dúcteis e Dúcteis-Rúpteis}

Nos grupos Paranoá e Bambuí, a fase $F_{1}$ é registrada apenas através de uma incipiente, recristalização de filossilicatos (foliação $S_{1}$ ) paralela ao plano de acamamento $S_{0}$, ao qual não se observam dobras associadas. Esta foliação estaria associada ao deslizamento inter-estratal, que marcaria o inicio da deformação (Freitas-Silva et al. 1994, Freitas Silva \& Campos 1998).

As principais estruturas planares e lineares impressas nas unidades dos grupos Canastra e Araxá foram geradas durante a fase $F_{1}$, refletindo a propagação dos sistemas de cavalgamentos São Bartolomeu/Maranhão e Descoberto. Esta fase é marcada por uma clivagem de fluxo $\left(S_{1 s}\right)$ penetrativa, que localmente ocorre associada a outra foliação milonitica, denominada $S_{1 c}$, caracterizando foliações do tipo $S-C$ de milonitos. As lineações de estiramento evidenciam transporte tectônico de oeste para leste.

A fase $F_{2}$ é responsável pelas principais estruturas dúcteis observadas nas litologias dos grupos Paranoá e Bambuí. Caracteriza-se por dobras de deslizamento $D_{2}$, com estilo dominantemente chevron, geralmente assimétricos de escala microscópica e megascópica. A follação de plano axial $S_{2}$ é melhor desenvolvida nas litologias pelíticas e apresenta 
atitude predominante de N56E/87NW. O Sistema de Cavalgamento Paranã foi estruturado na fase $F_{2}$, respondendo pela sobreposição do Grupo Paranoá ao Grupo Bambuí.

$A$ fase $F_{3}$ é caracterizada por dobras de deslizamento flexural $\left(D_{3}\right)$, com direção axial $\mathrm{N}-\mathrm{S}$, que inicialmente apresentam morfologia em chevrons amplos até apertados, simétricos e assimétricos, de escala microscópica a mesoscópica, com plano axial de direção N-S. Estas dobras apresentam foliação de plano axial, melhor representada nos tipos pelíticos através de uma clivagem ardosiana ou espaçada com atitude média NS/50W. A nucleação destas dobras ocorreu após a colocação do Grupo Canastra sobre os grupos Paranoá e Bambuí, e antecedeu a sobreposição tectônica do Grupo Araxá sobre os grupos Canastra e Paranoá. Contudo, o Grupo Araxá foi também afetado pelos estágios finais da fase $F_{3}$.

Ao final desta fase com a atenuação dos esforços tectônicos regionais, a rotação dos eixos de deformação e o desenvolvimento do Sistema de Cavalgamento Descoberto, o estilo em chevron dá lugar a dobras amplas e arqueamentos regionais de escala microscópica até megascópica.

$\mathrm{Na}$ fase de deformação $\mathrm{F}_{4}$ inicia-se a propagação das dobras $\mathrm{D}_{4}$, representadas por dobramentos suaves a moderados e/ou monoclinais os quais raramente desenvolvem clivagem. A escala deste dobramento é variável, desde submilimétrica até flexuras com comprimento de onda quilométrico mas, em geral, de baixa amplitude, o que torna este dobramento de fácil reconhecimento através do duplo caimento de lineações e da rotação dos elementos planares das fases anteriores. Os eixos medidos orientam-se com máximo estatístico N80W/18NW.

As dobras $D_{4}$ apresentam uma superposição temporal com as dobras $D_{3}$ tardias, correspondendo, desta forma, a dobras conjugadas. $A$ interferência entre as dobras $D_{2} / D_{3}$ e as dobras $D_{4}$ resultou nas principais estruturas dômicas do DF, os Domos de Brasília, do Pipiripau e de Sobradinho (Freitas-Silva \& Campos 1998). O padrão de interferência característico na região é do tipo de domos e bacias (Araújo Filho \& Faria 1992, Faria 1995, Freitas-Silva \& Campos 1998). Mais raramente ocorre o padrão zigue-zague de eixos paralelos (Araújo Filho \& Faria 1992).

\section{- Estruturas Rúpteis}

Durante a fase $F_{5}$ a compressão tectônica declina fortemente e a deformação progride de um regime dúctil-rúptil para o domínio rúptil. São gerados então fraturamentos e falhamentos normais generalizados, gerando sistemas de diacláses e juntas e reativando zonas de fraquezas pré-existentes onde, entretanto, o campo de stress manteve sua orientação (Freitas-Silva \& Campos 1998). Existem evidências de uma fase intensa de quebramento de extensão tardia, com juntas predominantes N-S preenchidas por quartzo, e cisalhantes NE e NW (Araújo Filho \& Faria 1992). 
Embora seja observada uma ampla distribuição das direções de fraturamento, predominam as familias de fraturas com direções N15E, N15W e N50-75W (Campos \& Freitas-Silva 1998). As duas primeiras correspondem, na maioria das vezes, a fraturas de extensão, enquanto a terceira, a fraturas de cisalhamento, que tem como par conjugado os sistemas com direção média N40-65E. Estas direções de fraturamentos são as mais expressivas no DF e condicionam, em sua maior parte, os grandes traços do padrão de drenagem.

A tectônica atuante na região durante o Paleozóico e o Cenozóico é ainda pouco estudada. As reativações tectônicas possivelmente tiveram importância fundamental sobre os processos intempéricos e erosivos, responsáveis pela compartimentação geomorfológica do DF.

Alguns estudos vêm descrevendo evidências de eventos de deformação pósproterozóicos. Campos \& Freitas-Silva (1998) citam a presença de testemunhos sedimentares, possivelmente do Cretáceo Inferior (Formação Abaeté), preservados em calhas formadas após a sedimentação destas unidades, que representam a preservação de um evento de reativação pré-cretácea. Relacionam a eventos de reativação tectônica a presença de grábens preenchidos por sedimentos coluvionares e eluvionares, como o da região de São Sebastião. Martins et al. (1994) descrevem em perfil do Metrô, na região de Águas Claras - DF, falhas aproximadamente N-S que seriam a reativação de linhas de fraqueza pré-cambrianas, responsáveis pela formação de calhas com o desenvolvimento associado de perfis de intemperismo. Blanco (1995) identifica em trechos do metrô da Asa Sul falhamentos subverticais em perfil de intemperismo, indicadores de um evento de reativação tectônica. Considera que o soerguimento de blocos e formação de horsts iniciou um processo de transporte do material erodido para as regiões mais baixas (grábens), formando solo poroso transportado (colúvio), posteriormente submetido a intenso processo de intemperismo.

\subsection{HIDROGRAFIA}

O Distrito Federal está localizado em uma região divisora de bacia na qual os rios são, em geral, de pequeno porte. Apesar disso, a área apresenta algumas bacias de drenagens consideradas importantes dentro do contexto regional que são as do São Bartolomeu, Descoberto, Preto, Maranhão e Alagado.

O ribeirão Sobradinho, que pertence à bacia do São Bartolomeu, segue em direção SE até quase sua confluência com o rio São Bartolomeu, onde então muda para uma direção aproximada EW. Apresenta uma amplitude altimétrica de aproximadamente $350 \mathrm{~m}$. 
Os principais tributários são os córregos Paranoazinho e Capão Grande, pela margem direita, e Capão Comprido, pela margem esquerda (figura 6).

O ribeirão Sobradinho, segundo metodologia de Strahler para hierarquização da drenagem, possui 12 canais de $1^{\text {a }}$ ordem e dois de $2^{\mathrm{a}}$ ordem, sendo classificado portanto, como de $3^{a}$ ordem. A relação morfométrica para a bacia indica um comprimento total dos canais de $53 \mathrm{~km}$ que para uma área de $144 \mathrm{~km}^{2}$, fornece um valor de densidade de drenagem baixo, de 0,37 (Novaes Pinto 1986b). O padrão de drenagem da bacia é retangular, no trecho em que afloram as litologias do Grupo Paranoá, sugerindo forte controle estrutural. Na área norte da bacia, próximo às nascentes do ribeirão Sobradinho, o padrão de drenagem é condicionado pelo Domo de Sobradinho (figura 6).

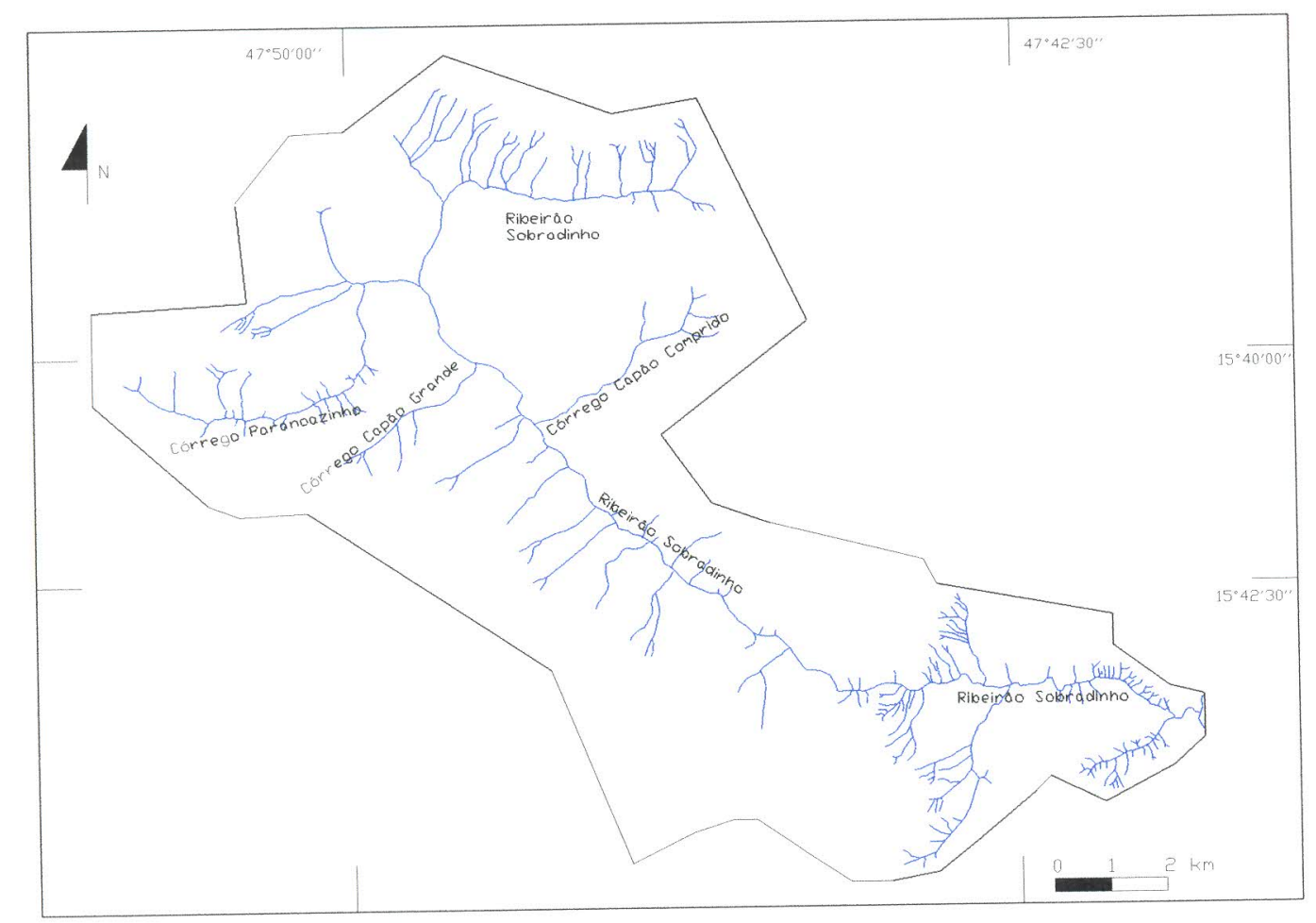

Figura 6. Mapa da rede de drenagem (extraída a partir de fotos aéreas de escala 1:40.000).

\subsection{SOLOS}

O trabalho mais completo realizado sobre os solos do DF foi o levantamento da EMBRAPA (1978). De acordo com Haridasan (1994) os trabalhos subseqüentes (EMBRAPA 1983, RADAMBRASIL 1982) incorporam essencialmente os dados deste levantamento original. Na área de estudo, de acordo com o mapa de solos da EMBRAPA (1978), as 
principais classes de solos são os latossolos (vermelho escuro, vermelho-amarelo e concrecionários), cambissolos/litólicos, hidromórficos e areias quartzosas.

Os latossolos são solos em mais avançado estado de intemperismo, apresentando muitos metros de espessura e se desenvolvem nas superfícies mais antigas e estáveis, de relevo plano ou suave ondulado e declividades menores que $8 \%$. Os latossolos vermetho escuros ocorrem principalmente no topo das chapadas, enquanto que os latossolos vermelho-amarelos predominam nas bordas de chapada e divisores, em superfícies planas abaixo dos topos da chapada da Contagem, sempre adjacente a classe anterior (Haridasan 1994).

Estes solos se caracterizam basicamente por terem sofrido lixiviação intensa dos elementos básicos com a acumulação de óxidos de ferro e de alumínio. São portanto, extremamente pobres na concentração de cálcio, magnésio, potássio e sódio e apresentam, em geral, a caulinita, gibbsita, materiais amorfos e óxido de ferro na fração argila, e quartzo nas frações areia e silte (EMBRAPA 1978). Kronberg et al (1979) estudaram a geoquímica de elementos maiores e traços em latossolos do DF, controlados mineralogicamente por gibbsita, e concluem que os solos da região mostram-se empobrecidos em relação aos elementos traços bem abaixo da abundância crustal, evidenciando intensa lixiviação.

Estes latossolos, apesar dos altos teores de argila, são essencialmente constituidos por argilominerais do tipo 1:1, resultando em baixas capacidades de retenção de água e de troca iônica, e alta infiltração. Além disso, em quase todo o perfil comportam-se como solos de textura mais grossa (Haridasan 1994).

As areias quartzosas são solos de textura arenosa, profundos, susceptíveis a erosão e geralmente pobres em nutrientes (EMBRAPA 1978). Estão diretamente ligados à desagregação das rochas quartzíticas subjacentes, especialmente nas regiões mais elevadas da chapada da Contagem.

Os cambissolos e solos litólicos ocupam as áreas de relevo ondulado a fortemente acidentado do vale do rio São Bartolomeu. Os cambissolos, extensos em área, ocupam terrenos com declividades maiores que $8 \%$, pois a alta taxa de erosão impede a formação de um solo profundo (Haridasan 1994). São solos jovens e pouco desenvolvidos, sendo comum a presença de minerais primários e a conservação de algumas estruturas originais da rocha matriz. São, normalmente, pouco profundos, muito susceptiveis a erosão e apresentam em geral cascalhos, concreções e fragmentos de rochas ao longo dos perfis, concentrando-se a maior parte na superfície do solo (EMBRAPA 1978). Os solos litólicos são pouco desenvolvidos, apresentando textura quase sempre de cascalho, e foram mapeados e associados aos cambissolos

A principal característica dos solos hidromórficos é a influência do nivel freático, muito próximo à superfície, ou mesmo surgente. Ocupam a várzea do ribeirão Sobradinho e, 
em alguns locais, se associam a terrenos de murundus, podendo ser encontrados ainda nas bordas das chapadas. São geralmente pouco profundos e de textura predominantemente argilosa. A coloração do horizonte superficial varia de esbranquiçada, denotando a pouca acumulação de matéria orgânica, até o cinza escuro, quando há significativa acumulação (EMBRAPA 1978). 


\section{Caracterização Climática e Balanço Hídrico}

A análise de elementos climáticos permite compreender as variações do clima ao longo do tempo, que exercem importante papel sobre a disponibilidade hídrica de uma região. Em relação aos estudos de águas subterrâneas, essa análise permite avaliar os aportes e perdas no ciclo hidrológico que determinam as condiçōes de recarga dos aqüiferos.

De acordo com a classificação de Köppen, o clima do DF enquadra-se entre os tipos Tropical (Aw) e Tropical de Altitude (Cwa e Cwb) (CODEPLAN 1984). Esta classificação considera a variação da temperatura, diretamente relacionada às diferenças altimétricas. $A$ caracteristica marcante em relação ao clima da região é a existência de duas estações bem definidas: chuvosa no verão e seca no inverno. $O$ período chuvoso corresponde aos meses de outubro a abril e o seco se estende de maio a setembro.

\subsection{LEVANTAMENTO E AQUISIÇÃO DE DADOS HIDROLóGICOS}

A análise climatológica da área de estudo foi realizada a partir dos dados da estação climatológica da EMBRAPA (Empresa Brasileira de Pesquisa Agropecuária). Esta estação localiza-se a noroeste da cidade de Planaltina, cerca de $5 \mathrm{~km}$ da bacia estudada e, portanto, apresenta dados representativos das condições climáticas da área de estudo. $O$ seu periodo de observação iniciou-se em julho de 1973 e estende-se até a presente data, o que produz uma série de dados e médias estabelecidos após longo periodo de observações e registros.

A CAESB (Companhia de Água e Esgotos de Brasília) possui um banco de dados hidrológicos contendo séries históricas de postos pluviométricos e fluviométricos desde 1971. Sua rede pluviométrica dispõe atualmente de 23 estações de medição no DF. Deste total apenas uma, a de Sobradinho, localiza-se dentro da área de estudo. A fim de permitir uma melhor caracterização da precipitação média de chuva na bacia, foram utilizados também os dados pluviométricos das 3 estações mais próximas da área estudada, que são Contagem, Paranoá e Colégio Agrícola (tabela 1).

O ribeirão Sobradinho apresenta duas estações de medição da descarga fluvial (tabela 1 e figura 7). $\mathrm{Na}$ análise dos dados, optou-se pela utilização dos dados da estação mais a montante, por apresentar uma série histórica maior de 18 anos (1978 a 1995), contra a outra de apenas 5 anos (a partir de 1994). 
A avaliação da capacidade hídrica de uma região pode ser melhor realizada em função da precisão e freqüência com que são medidos os parâmetros hidrometeorológicos, assim como da distribuição espacial da rede de medidas (Mattos \& Villela 1987). Sob esse aspecto, a área de estudo apresenta condições muito adequadas para sua caracterização climática (tabela 1 e figura 7).

Foram levantados dados mensais e anuais das variáveis meteorológicas destas estações. Como existem diferenças no período de observação das diferentes estações adotadas, optou-se pela utilização dos dados de 1979 a 1995, a fim de se obter maior coerência na comparação e avaliação dos resultados, já que para esse periodo os dados disponiveis são bastante completos. Além disso, a operação da rede da CAESB passou ao seu controle apenas em 1976, com o sistema passando por reformas até 1979 , de modo que o conjunto de dados tem maior densidade após essa época (Itonaga \& Eid 1995). Um período de 17 anos de registros e observações adotado para esse tipo de estudo permite supor uma boa representatividade das condições hidrológicas da bacia.

Tabela 1. Estações consideradas para a análise climática da área de estudo ( ${ }^{*}$ a altitude foi estimada com base nos mapas planialtimétricos 1:25.000 do (BGE/CODEPLAN).

\begin{tabular}{|c|c|c|c|c|c|}
\hline \multirow{2}{*}{ Estação } & \multicolumn{3}{|c|}{ Localização } & \multirow{2}{*}{ Categoria } & \multirow{2}{*}{$\begin{array}{l}\text { Período de } \\
\text { Observação }\end{array}$} \\
\hline & Latitude & Longitude & $\begin{array}{c}\text { Altitude* } \\
\text { (m) }\end{array}$ & & \\
\hline EMBRAPA - CPAC & $15^{\circ} 35^{\prime} 30^{\prime \prime} \mathrm{S}$ & $47^{\circ} 42^{\prime} 30^{\prime \prime} \mathrm{W}$ & 1007 & Climatológica & Jul/73 até presente \\
\hline Sobradinho & $15^{\circ} 40^{\prime} 00^{\prime \prime} \mathrm{S}$ & $47^{\circ} 49^{\prime} 49^{\prime \prime} \mathrm{W}$ & 1110 & Pluviométrica & $\begin{array}{c}\text { Out/72 a Dez/84, } \\
\text { Jan/87 até presente }\end{array}$ \\
\hline Colégio Agrícola & $15^{\circ} 40^{\prime} 00^{\prime \prime} \mathrm{S}$ & $47^{\circ} 43^{\prime} 43^{\prime \prime} \mathrm{W}$ & 1140 & Pluviométrica & Jan/71 até presente \\
\hline Paranoá & $15^{\circ} 47^{\prime} 00^{\prime \prime} \mathrm{S}$ & $47^{\circ} 43^{\prime} 43^{\prime \prime} W$ & 900 & Pluviométrica & Out/78 até presente \\
\hline Contagem & $15^{\circ} 39^{\prime} 00^{\prime \prime} \mathrm{S}$ & $47^{\circ} 53^{\prime} 53^{\prime \prime} \mathrm{W}$ & 1285 & Pluviométrica & Jan/71 até presente \\
\hline Ribeirão Sobradinho & $15^{\circ} 43^{\prime} 47^{\prime \prime} \mathrm{S}$ & $47^{\circ} 44^{\prime} 44^{\prime \prime} \mathrm{W}$ & 970 & Fluviométrica & $\begin{array}{c}\text { Nov/78 a Ago/81, } \\
\text { Jan e Fev/93, Mai/83 } \\
\text { a Dez/89, Jun/90 a } \\
\text { Out/95 }\end{array}$ \\
\hline $\begin{array}{l}\text { Rib. Sobradinho } \\
\text { (posto novo) }\end{array}$ & $15^{\circ} 43^{\prime} 37^{\prime \prime} \mathrm{S}$ & $47^{\circ} 42^{\prime} 42^{\prime \prime} W$ & 910 & Fluviométrica & Ago/94 até presente \\
\hline
\end{tabular}




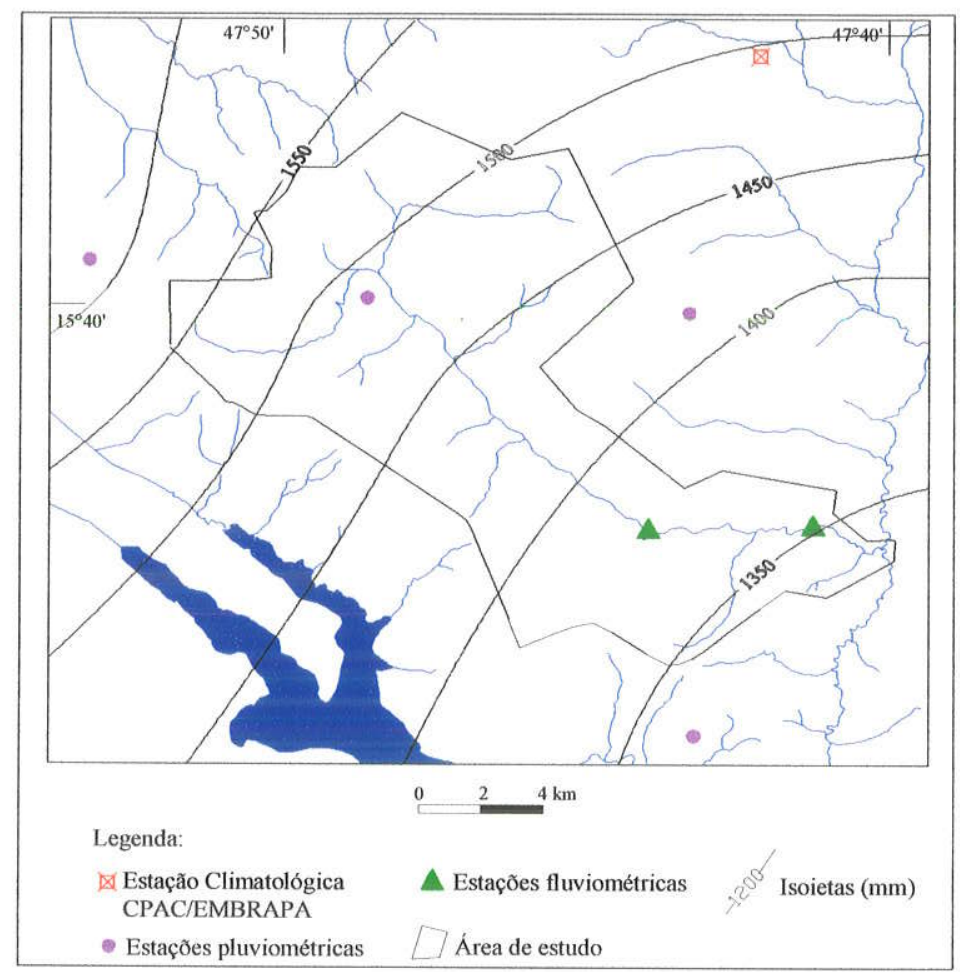

Figura 7. Mapa de isoietas da área de estudo e de localização das estações hidrológicas.

\subsection{PRINCIPAIS PARÂMETROS CLIMÁTICOS CONSIDERADOS}

\subsubsection{PreCiPITAÇÃo}

A distribuição das chuvas ao longo do ano é bastante irregular na área de estudo (figura 8). A estação pluviométrica de Sobradinho, por exemplo, apresenta nos meses mais chuvosos, que são novembro, dezembro e janeiro, uma precipitação média de $725,5 \mathrm{~mm}$, ou seja, o trimestre concentra $49,9 \%$ da precipitação média anual (1453 mm).

Por outro lado praticamente não chove na época seca. $O$ trimestre mais seco, que vai de junho a agosto, apresenta nas estações de Sobradinho e do CPAC precipitação média de cerca de $35 \mathrm{~mm}$. A estação seca é bastante rigorosa, porque nesse período toda a região central do Brasil está sob o domínio da Massa Tropical Atlântica (MTA) de grande estabilidade. Ocasionalmente, com a passagem de frentes frias, os ventos do nordeste da MTA são substituídos pelos ventos do quadrante sul do Anticiclone Migratório Polar, resultando chuvas fracas e esparsas (CODEPLAN 1984). 


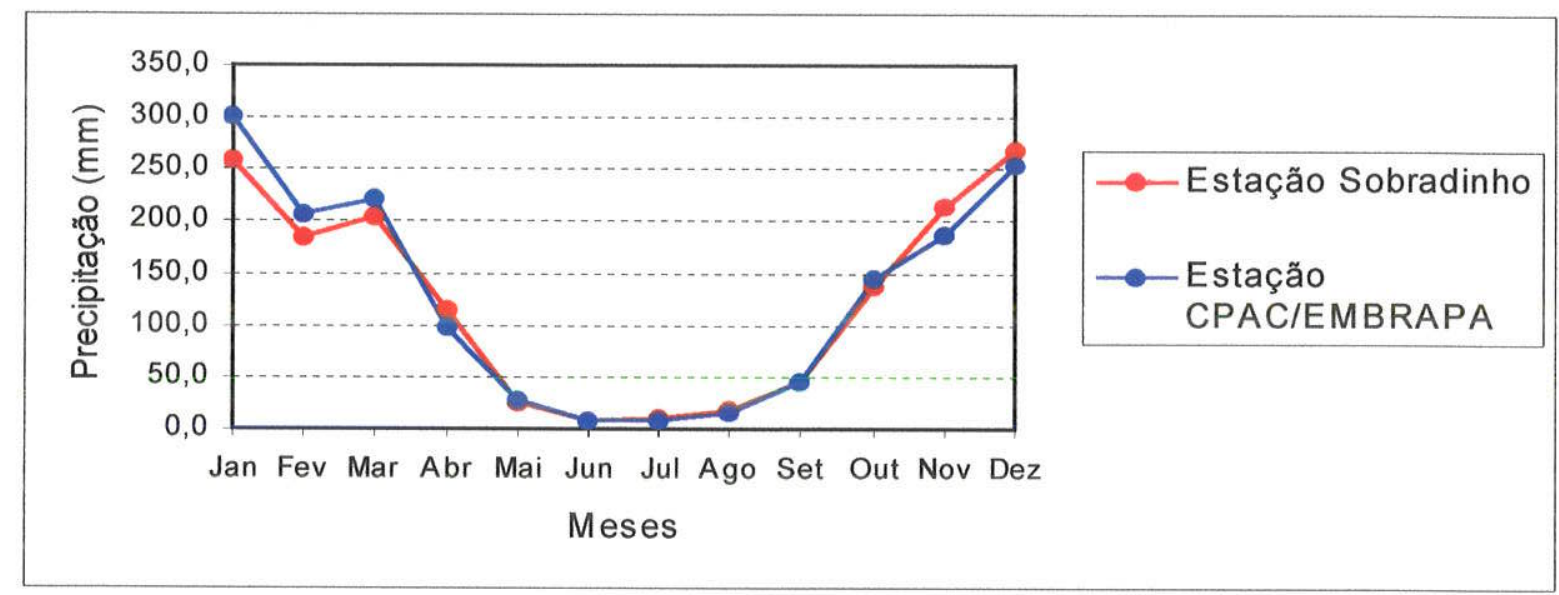

Figura 8.Variação da precipitação média mensal nas estações de Sobradinho e do CPAC/EMBRAPA (período 1979 a 1995).

A análise da variação inter-anual das precipitações mostrou que nem sempre existe correspondência de anos secos, normais e de alta pluviosidade, entre as diferentes estações consideradas. Este resultado pode ser considerado normal, já que as medições de precipitação são pontuais e sofrem significativas variações espaciais. Por isso, optou-se na presente análise pela utilização da média dos totais pluviométricos das 5 estações selecionadas para cada ano (figura 9).

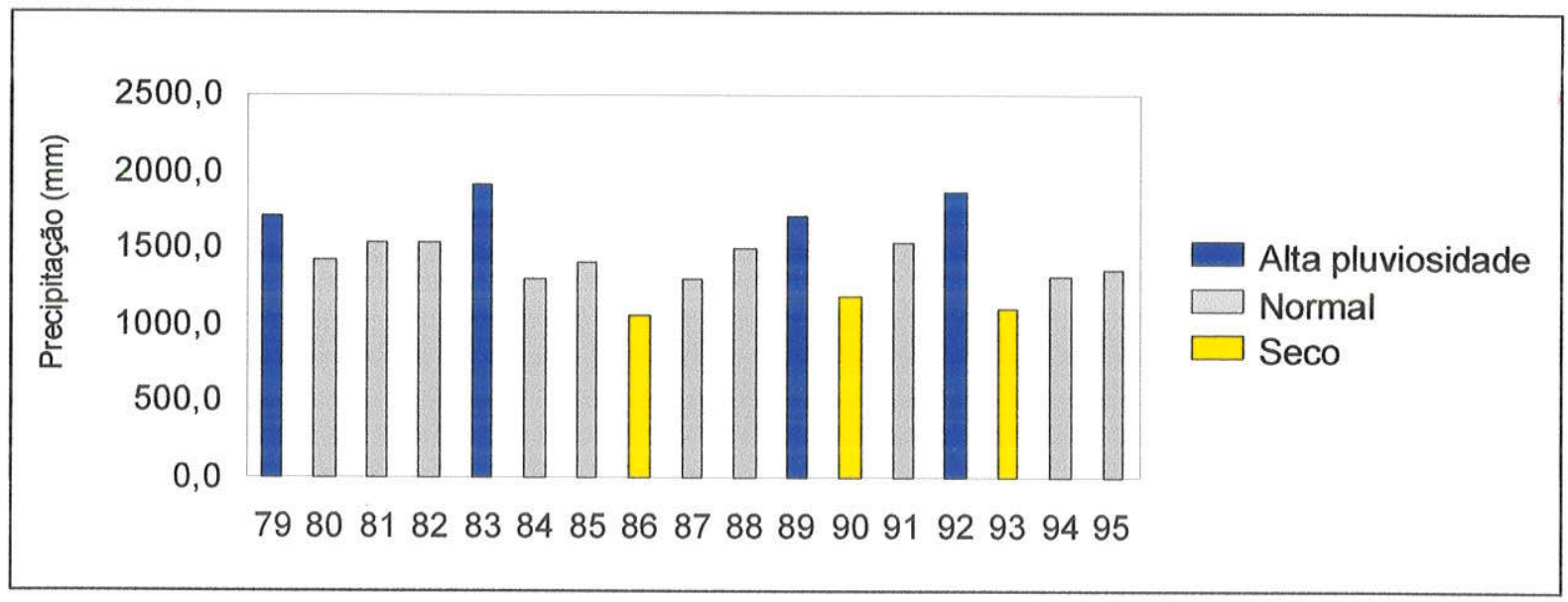

Figura 9. Variação da precipitação média anual das estações analisadas (foram considerados anos de precipitação normal aqueles com valores que se afastam até $13 \%(200 \mathrm{~mm})$ da média total das estações).

Observa-se marcadamente a existência de anos secos e chuvosos com uma certa periodicidade (figura 9). Estes períodos se repetem com certa regularidade a cada 3 ou 4 anos. Os anos mais chuvosos correspondem àqueles de 1979, 1983, 1989 e 1992 e os secos 1986, 1990 e 1993.

$\mathrm{Na}$ avaliação da precipitação em uma área, e especialmente para a determinação do balanço hídrico de uma bacia hidrográfica, é fundamental a determinação da altura 
média de precipitação. Esta análise foi feita com base em totais anuais, a fim de se obter representatividade das disponibilidades hídricas da bacia no decorrer do período escolhido para análise.

Entre as metodologias clássicas mais utilizadas para a determinação da precipitação média em uma área, o método das Isoietas é o mais preciso (Villela \& Matos 1975, Shaw 1994). O traçado de linhas de igual precipitação (isoietas) permite localizar espacialmente a distribuição de precipitações médias, sendo o cálculo feito através da determinação da área entre as linhas e fazendo-se uma média ponderada. Foi utilizada como função de interpolação no traçado das isoietas o método da krigagem (figura 7). Oliveira et al. (1996) verificaram a adequação deste método geoestatístico ao cálculo da precipitação média quando comparada a métodos tradicionais como de Thiessen, Média Aritmética e Estação-Ângulo. Desta forma, a área de estudo apresenta uma precipitação média de 1442,5 mm.

\subsubsection{TEMPERATURA}

A temperatura média anual na área é de $22^{\circ} \mathrm{C}$, enquanto a mínima e a máxima são respectivamente, de 16,3 e $27,6^{\circ} \mathrm{C}$. Os meses mais frios vão de maio a agosto e correspondem, aproximadamente, à estação seca (maio a setembro). Os meses mais quentes são setembro, outubro e novembro, e apresentam temperaturas médias oscilando entre 22,8 e $23,3^{\circ} \mathrm{C}$ (figura 10).

As variações da temperatura média mensal podem ser consideradas pequenas na área (figura 10). A diferença entre a temperatura média do mês mais frio (julho) e do mais quente (outubro), é de $3,7^{\circ} \mathrm{C}$. As amplitudes médias mensais são altas, ficando entre 11,6 e $9,5^{\circ} \mathrm{C}$, no período chuvoso, e na época seca chegando a valores superiores a $13^{\circ} \mathrm{C}$.

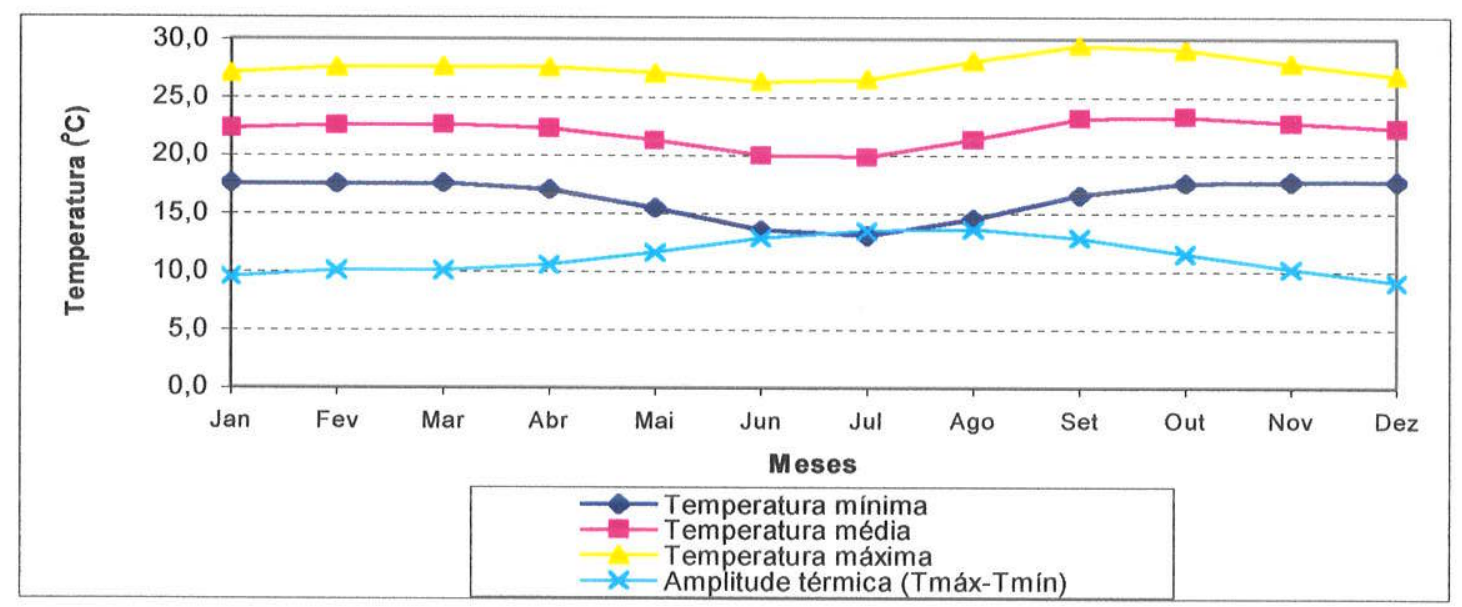

Figura 10. Variação da temperatura média mensal na estação CPAC/EMBRAPA (período de 1979 a 1995). 


\subsubsection{UMIDADE DO AR E VELOCIDADE DO VENTO}

O aspecto mais característico do clima do DF no período de seca é a diminuição da umidade relativa do ar, sobretudo no período mais quente do dia entre as 12 e 15 horas, quando os valores chegam a menos de $20 \%$. Entretanto, devido a variabilidade diária da temperatura (amplitudes médias superiores a $13^{\circ} \mathrm{C}$ ), os valores médios diários são mais elevados ficando entre 57 e $71 \%$. Na estação chuvosa os valores médios mensais são superiores a $70 \%$ (tabela 2 ).

A variação na velocidade do vento na área de estudo ao longo do ano é pequena (tabela 2). Os maiores valores ocorrem no periodo de julho a setembro, que corresponde aproximadamente à estação seca. A direção predominante dos ventos é de SE/E.

Tabela 2.Valores médios mensais de umidade relativa do ar e velocidade do vento na estação CPAC/EMBRAPA (periodo de 1979 a 1995).

\begin{tabular}{|c|c|c|c|c|c|c|c|c|c|c|c|c|}
\hline & Jan & Fev & Mar & Abr & Mai & Jun & Jul & Ago & Set & Out & Nov & Dez \\
\hline Umidade Relativa do Ar (\%) & 77,8 & 76,5 & 76,2 & 74,4 & 71,1 & 66,7 & 61,4 & 56,8 & 58,9 & 66,4 & 73,3 & 78,1 \\
\hline $\begin{array}{c}\text { Velocidade do vento a 2 m } \\
\text { do solo (m/s) }\end{array}$ & 1,6 & 1,6 & 1,4 & 1,5 & 1,8 & 1,8 & 2,0 & 2,1 & 1,9 & 1,8 & 1,7 & 1,7 \\
\hline
\end{tabular}

\subsubsection{EVAPOTRANSPIRAÇÃO POTENCIAL}

A evapotranspiração representa a perda conjunta de água do solo, pela evaporação, e das plantas, pela transpiração. O escoamento superficial e a evapotranspiração são os principais fatores determinantes da perda de água em um sistema hidrológico e portanto, são importantes para a quantificação das disponibilidades hídricas de uma região.

A evapotranspiração é o parâmetro de mais difícil quantificação no ciclo hidrológico. Os diversos estudos buscando quantificar este parâmetro, introduziram o conceito da evapotranspiração potencial. Thornthwaite (1948) foi o primeiro a utilizá-lo, e definiu-o como sendo a água evapotranspirada de uma superficie natural coberta por uma vegetação em fase de crescimento ativo e com o teor de umidade do solo próximo a capacidade de campo. A evapotranspiração real é a quantidade de água transferida para a atmosfera por evaporação e transpiração, nas condições reais existentes de fatores atmosféricos e umidade do solo (Tucci 1993). A evapotranspiração potencial é, portanto, um limite superior da evapotranspiração real.

A estação climatológica da EMBRAPA-CPAC apresenta dados de evaporação potencial em superficies livres, obtidos em evaporímetros do tipo Tanque Classe $A$ com séries de valores bastante incompletos e, por isso, não apresentam boa confiabilidade. Dispõem ainda de valores de evapotranspiração potencial calculados através do método de Penman, para períodos decendiais (dez dias), pelo Laboratório de Agrometerologia do CPAC-EMBRAPA para uma série de dados de 10 anos. Estes dados são considerados 
como norma, ou seja, valores de referência para a estação climatológica da EMBRAPA e foram transformados em valores médios mensais (tabela 3 ).

Tabela 3. Valores médios mensais de evapotranspiração potencial obtidos através do método de Penman (dados da estação da EMBRAPA-CPAC).

\begin{tabular}{|c|c|c|c|c|c|c|c|c|c|c|c|c|c|}
\hline & Jan & Fev & Mar & Abr & Mai & Jun & Jul & Ago & Set & Out & Nov & Dez & Total \\
\hline $\begin{array}{c}\text { ETP } \\
(\mathbf{m m})\end{array}$ & 155 & 143 & 149 & 135 & 134 & 133 & 147 & 176 & 181 & 167 & 156 & 145 & 1821,0 \\
\hline
\end{tabular}

\subsection{BALANÇO HídRICO}

O balanço hídrico relaciona as entradas e saídas de água que ocorrem em uma área durante um certo período de tempo. A sua utilização em estudos hidrogeológicos visa estimar a quantidade de água disponível que participa da recarga dos aqüiferos. É importante ressaltar que o balanço hídrico aplicado a seguir objetiva estimar a ordem de magnitude e importância dos termos que o compõem, através de valores médios anuais, e por isso algumas simplificações são feitas.

Uma das formas de se descrever o balanço hídrico, que é uma equação da continuidade, pode ser expressa através da seguinte relação (Custódio \& Llamas 1996):

$P=E T R+E X+\Delta R$, sendo $E T R$ a evapotranspiração real, EX os excedentes de água, representados pelo escoamento superficial e a infiltração, e $\Delta R$ a variação na reserva de água no solo utilizável pelas plantas.

O termo $\Delta R$ é também conhecido como capacidade de armazenamento (CA), que é um valor compreendido entre a capacidade de campo do solo e o ponto de murchamento permanente, a partir do qual as plantas não conseguem mais retirar do solo a água capilar (Custódio \& Llamas 1996). O armazenamento de água no solo pode ser desprezado no balanço hídrico desde que o período ao qual se aplica o método seja relativamente longo, ou seja, da ordem de um ano, pois o ciclo hidrológico é um sistema fechado sem perda ou criação de água (Ometo 1981 apud Cicco et al. 1985). Como na presente análise o período avaliado é de 17 anos, a quantidade de água disponivel no solo para as plantas $(\Delta R)$ foi considerado desprezível.

Como foi calculado o valor da precipitação média na bacia pelo método das isoietas, na equação do balanço hídrico falta determinar portanto, o termo EX, representado pelos escoamentos subterrâneo e superficial, e a evapotranspiração real (ETR). Em estudos hidrogeológicos o termo mais importante em um balanço hidrológico é representado pelo volume de água que infiltra no subsolo e efetivamente alcança o aqüifero, que pode ser determinado através dos hidrogramas dos rios por métodos gráficos. Existem diferentes 
(ETR). Em estudos hidrogeológicos o termo mais importante em um balanço hidrológico é representado pelo volume de água que infiltra no subsolo e efetivamente alcança o aqüífero, que pode ser determinado através dos hidrogramas dos rios por métodos gráficos. Existem diferentes formas de separar em um hidrograma o escoamento superficial do subterrâneo. Foi adotado, neste estudo, o método de Barnes que apresenta os resultados mais confiáveis (Custódio \& Llamas 1996).

Antes de se proceder a análise do hidrograma do ribeirão Sobradinho, foram levantados junto à CAESB dados mensais do volume de esgoto lançado pela estação no ano de 1998, a fim de avaliar a influência do lançamento de esgotos sobre a descarga fluvial. Estes valores possivelmente representam o limite superior do volume de esgotos produzidos no período de interesse da presente análise, que vai de 1979 a 1995 . Foi obtida uma vazão média de $0,066 \mathrm{~m}^{3} / \mathrm{s}$, que comparada aos valores médios de descarga fluvial do ribeirão pode ser considerada desprezível, até mesmo no período de menor vazão, que corresponde a $1,16 \mathrm{~m}^{3} / \mathrm{s}$ no mês de setembro.

A análise do hidrograma (figura 11) através do método de Barnes indicou um volume médio infiltrado (escoamento subterrâneo) anualmente equivalente a $410 \mathrm{~mm}$ e de escoamento superficial equivalente a $243 \mathrm{~mm}$. A diferença entre a média de precipitação da bacia $(1442,5 \mathrm{~mm})$ e a soma dos escoamentos subterrâneo e superficial (termo EX) fornece um valor de $789,5 \mathrm{~mm}$, que pode ser considerado uma estimativa da evapotranspiração real na bacia.

A evapotranspiração real na bacia representa portanto, 54,7 \% da média anual de chuva. Este valor é bastante razoável, pois Coimbra (1987) obteve para a bacia do rio São Bartolomeu, e que inclui portanto a área de estudo, um valor de $884,2 \mathrm{~mm}$ para a evapotranspiração real.

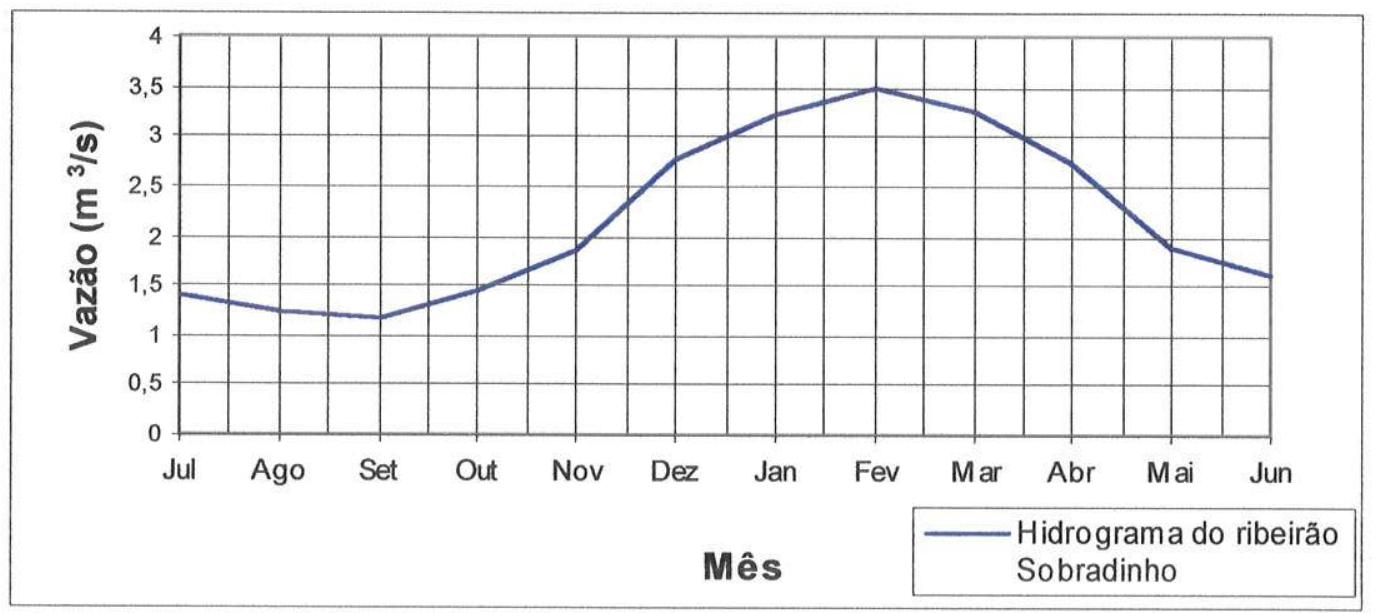

Figura 11. Hidrograma do ribeirão Sobradinho (valores médios mensais correspondentes ao período de 1979 a 1995). 


\section{HIDROGEOLOGIA}

\subsection{INTRODUÇÃO}

O domínio hidrogeológico do cristalino representa cerca de $58 \%$ do território nacional no qual afloram rochas ígneas e metamórficas. Corresponde a uma área de $5.340 .000 \mathrm{~km}^{2}$, da qual aproximadamente $85 \%$ é recoberta pelo manto de intemperismo (Cavalcante \& Rebouças 1990). Nestes tipos de terrenos são reconhecidos os dois tipos clássicos de aqüiferos. $O$ aqüifero freático, associado à zona saturada no manto de intemperismo e o fraturado, condicionado à ocorrência das rochas cristalinas.

O conhecimento sobre o fluxo da água em meios porosos, que controla a dinâmica da água no manto de intemperismo, se encontra bastante consolidado. Mais recentemente, principalmente a partir da década de 70 , foram desenvolvidos estudos sobre meios fraturados. Isto se deveu em grande parte à potencialidade de algumas áreas fraturadas em suprir água e da necessidade de explorar e proteger estes aqüiferos, em função da ocupação humana de áreas em terrenos cristalinos.

Os aqüiferos fraturados se desenvolvem em rochas metamórficas e igneas cuja permeabilidade primária é baixa, estando o armazenamento e a circulação condicionados à ocorrência de descontinuidades no maciço rochoso. Nestas rochas a porosidade primária raramente ultrapassa $5 \%$, pois os espaços intercristalinos são diminutos e muitos não estão conectados, resultando em permeabilidades extremamentes baixas (Freeze \& Cherry 1979).

As descontinuidades físicas responsáveis pela permeabilidade secundária destas rochas são geradas basicamente por processos de intemperismo e de deformação (controle estrutural). As estruturas responsáveis por essa permeabilidade podem ter grande variedade como falhas, fraturas, juntas, clivagem e xistosidade, e podem ser geradas tanto em ambientes extensionais quanto compressivos.

O intemperismo envolve processos físicos (dilatação por variações de temperatura ou congelamento de água) e químicos (hidrólise, oxidação e dissolução). Os principais processos intempéricos responsáveis pela geração da permeabilidade secundária são a alteração químicas e dissolução das rochas, que variam em intensidade devido a uma série de fatores, tais como clima, composição da rocha e a presença de estruturas que facilitam a circulação da água, como por exemplo, as fraturas. Os efeitos do intemperismo podem atingir vários metros de profundidade em terrenos cristalinos sob clima tropical. A dissolução é um processo 
processo especialmente importante em rochas calcárias, gerando as estruturas cársticas. Entretanto, muitas vezes os processos intempéricos podem contribuir para a diminuição da permeabilidade das rochas. Rochas ricas em minerais silicáticos, por exemplo, apresentam um resíduo insolúvel na forma de óxidos de ferro ou alumínio, que tende muitas vezes a obstruir as pequenas fraturas após o início do intemperismo (Freeze \& Cherry 1979).

Os terrenos fraturados podem ser considerados por sua própria natureza como heterogêneos e anisotrópicos. As próprias fraturas não apresentam isotropia ao longo de seus planos (Hausman 1980). No caso de fraturas relativamente estreitas e abundantes o terreno pode ser considerado macroscopicamente homogêneo. Entretanto, como a abertura e freqüência das fraturas varia significativamente com a orientação, o meio fraturado, mesmo que possa se considerado homogêneo, se comporta, em geral, como anisotrópico (Custódio \& L.lamas 1996).

De forma geral, a permeabilidade das rochas fraturadas decresce rapidamente com a profundidade. As fraturas tendem a se fechar com o aumento da profundidade devido às tensões verticais, impostas pelas cargas sobrejacentes, e laterais, relacionadas às tensões confinantes horizontais de origem tectônica. Um aspecto muito discutido sobre poços em aqüíferos fraturados é a relação produtividade e profundidade, que freqüentemente é avaliada pelas entradas de água. Menegasse (1991) na região a noroeste de São Paulo considera que a maior quantidade de entradas de água ocorre entre 50 e $100 \mathrm{~m}$. Cavalcante (1990) observa na região de Atibaia (SP), que $85,7 \%$ das entradas ocorrem até $154 \mathrm{~m}$. Em região de clima semiárido dos estados do Rio Grande do Norte e Paraiba, 90\% das entradas ocorrem até $40 \mathrm{~m}$ de profundidade (Costa 1986).

O fluxo através das fraturas se faz isoladamente ou através de um sistema de fraturas, havendo sempre uma intercomunicação entre micro e macro-fraturas (Hausman 1980). Este fluxo é uma questão bastante complexa. Em fraturas estreitas é predominantemente laminar (Suszcynski 1968 apud Custódio \& Llamas 1996), mas em fraturas de maior abertura pode envolver os fluxos laminar não linear ou turbulento.

Desde os primeiros estudos sobre terrenos cristalinos, um dos principais objetivos foi entender os fatores que controlam a produtividade dos poços profundos, aspecto fundamental para o aproveitamento destes aqüíferos. Deste modo vários fatores têm sido levantados entre os quais se destacam os climáticos, geomorfológicos, litológicos e estruturais. 


\section{- Clima}

O clima determina a disponibilidade de água que influi diretamente nas condições de recarga e portanto, as reservas do aqüifero. Além disso, nos terrenos cristalinos o clima desempenha importante papel na evolução dos processos pedogenéticos e intempéricos responsáveis pela formação do manto de cobertura. Como manto de cobertura são incluidos os materiais alóctones (depósitos fluviais, eólicos, gravitacionais, ..) e autóctones (manto de intemperismo) (Costa 1986), que pode atingir até 150 m de espessura (Cavalcante \& Rebouças 1990).

A influência desempenhada pelo manto sobre o aqüifero fraturado dependerá da sua espessura e composição granulométrica (Costa 1986). Um aspecto comum em poços que exploram aqüiferos fraturados é uma vazão inicial moderada ou alta que decresce rapidamente com o tempo, que está freqüentemente relacionada ao baixo armazenamento de água próximo ao poço, que sugere a importância da drenança de água de zonas intemperizadas ou de aluviões e colúvios, de maior permeabilidade (Davis \& DeWiest 1966). A interação hidráulica entre manto e aqüifero fraturado sotoposto foi verificada por testes de bombeamento monitorados por piezômetros multiníveis (Cavalcante 1990, Menegasse 1991).

Em climas úmidos, a circulação de água facilita os processos de intemperismo próximos à superfície e ao longo das fraturas. Costa (1986) destaca a relação entre manto e clima, pois poços em áreas cobertas por espesso manto de cobertura no sul do Brasil apresentam vazões médias em torno de 5 vezes superiores àquelas em áreas praticamente sem cobertura do nordeste semi-árido.

\section{- Geomorfologia}

A geomorfologia tem sido utilizada em algumas regiões como indicador da produtividade de poços. Poços localizados normalmente nas baixas encostas ou fundos de vales retilíneos apresentam elevados valores de vazão média, quando comparados àqueles não associados a estas estruturas (Menegasse 1991). Valores decrescentes de vazão específica em poços ocorrem respectivamente, em talvegues, encostas e por fim elevações (Costa 1986).

Henriksen (1995) considera que os valores mais elevados de produtividade de poços em regiões planas e de vale são justificadas pelo fato de serem zonas de descarga, pela maior infiltração de água por causa da cobertura mais espessa, a recarga adicional de corpos de água superficiais e de fraturas paralelas aos vales.

Entretanto, a compartimentação topográfica nem sempre apresenta resultados satisfatórios e muitas vezes não é uma boa indicadora da vazão específica de poços (Yin \& 
Brook 1992, Knopman \& Hollyday 1993). Yin \& Brook (1992) observam, através de análise estatística, que quanto maior o número de subdivisões do relevo, maiores são as diferenças de produtividade obtidas entre os poços.

\section{- Litologia}

O fator litologia apresenta grande importância em aqüiferos fraturados pois influencia os padrões de fraturamento e as caracteristicas do manto de intemperismo (Fernandes 1997). De forma geral, as rochas de granulação grossa tendem a formar melhores aqüíferos que aquelas de granulação fina. As tensões que geram as descontinuidades nas rochas são diretamente proporcionais ao módulo da elasticidade, e sendo esse módulo mais elevado nas rochas granulares, as tensões de tração geradas pelos esforços compressivos assumem valores maiores, gerando fraturas mais abertas em rochas como, por exemplo, os gnaisses, do que em filitos (Costa 1980).

Costa (1986) estabelece a seguinte ordem decrescente de aptidão para armazenamento e fornecimento de água: gnaisses, quartzitos e migmatitos orientados; micaxistos; granitos, rochas granulares magmáticas e migmatitos não orientados; xistos, filitos e ardósias. Em regiões de ocorrência de rochas carbonáticas existe uma tendência a serem obtidas maiores vazões em relação às rochas ígneas e metamórficas, devido à intensa atuação dos processos de dissolução, responsáveis pela formação do aqüifero cárstico-fraturado. Menegasse (1991) identificou as maiores vazões médias de poços tubulares como associadas às rochas carbonáticas e os menores valores em rochas graníticas.

Muitas vezes os contatos entre litologias com diferenças texturais e/ou mineralógicas podem formar importantes zonas com boa permeabilidade. A formação de zonas de maior permeabilidade nestes casos possivelmente se deve a processos de fraturamento relacionados a mecanismos de intrusão e/ou a diferenças de comportamento reológico das rochas quando submetidas à deformação rúptil (Fernandes 1997). Sodré et al. (1986) identificaram a ocorrência de veios de quartzo que condicionam a ocorrência de poços com vazões mais elevadas cujo fraturamento aberto está relacionado à diferença de competência e a homogeneidade mineralógica destes veios, em relação às rochas encaixantes (gnaisses, migmatitos, charnokitos, granitóides e granulitos). Além disso, o contato entre os veios de quartzo e rochas encaixantes favorece uma maior circulação das águas. Menegasse (1991) destaca a importância de áreas de contato litológicos entre metapelitos e rochas diversas, como metacalcários, anfibolitos, granitos e quartzitos, para fins de prospecção. 
Estudos mostram que grandes diferenças de vazões em poços não se relacionam apenas ao tipo de rocha, apesar de existir uma tendência a menores vazões ocorrerem em filitos e rochas de granulação fina, e as maiores em rochas carbonáticas (Davis \& DeWiest 1966). A análise estatística de 4391 poços revelou que o fator litologia era responsável por apenas $12 \%$ da variação dos valores de vazão especifica (Knopman \& Hollyday 1993).

\section{- Estrutural}

Os primeiros estudos hidrogeológicos em terrenos cristalinos enfatizaram a utilização de fraturas identificadas em fotografias aéreas, como áreas promissoras para a locação de poços (Parizek 1964, Setzer 1964, Gonçalves 1978). Os traços de fratura são considerados como manifestações superficiais de zonas verticais de fraturamento (Lattman \& Nickelson 1958 apud Krothe \& Bergeron 1981). Grehs (1968) considera que as "fraturas geológicas" (lineações observáveis em fotos aéreas) correspondem no terreno a zonas de fraturamento com largura variável em função do módulo de elasticidade da rocha, apresentando maior densidade de fraturas no centro. Ainda hoje o conceito "riacho fenda" (Siqueira 1963), é utilizado como importante fator prospectivo no país. Ele considera que drenagens superficiais retilíneas controladas por zonas fraturadas apresentam boas condições de infiltração de água na rocha, favorecendo seu armazenamento em subsuperficie e resultando em poços com melhores vazões.

Em estudos regionais para prospecção de aqüíferos fraturados, para os quais existe uma grande quantidade de lineamentos, têm sido utilizados testes de "reprodutibilidade" (Mabee et al. 1994, Sander et al. 1997), que tentam minimizar a subjetividade que existe nos critérios para a extração e classificação dos lineamentos, de modo a reduzir o número de lineamentos a serem verificados posteriormente, em campo.

No Brasil vários estudos têm demonstrado a importância da identificação de lineamentos, que interpretados dentro do contexto tectônico local, permitem compreender o papel dos diferentes tipos de fraturas sobre a produtividade dos poços (Bertachini 1987, Menegasse 1991). Na região a noroeste da Grande São Paulo por exemplo, o valor médio de vazão especifica dos poços associados às estruturas lineares (falhas, fraturas e contatos litológicos) apresentam vazões em torno de $11 \mathrm{~m}^{3} / \mathrm{h} . \mathrm{m}$, enquanto que os demais apresentam média de $1,5 \mathrm{~m}^{3} / \mathrm{h} . \mathrm{m}$ (Menegasse 1991).

A nível mais detalhado o fluxo de água subterrânea em rochas fraturadas depende de propriedades como orientação, densidade, abertura, textura da superfície e grau de 
conectividade, este último de grande importância (Domenico \& Schwartz 1990). É importante também a comunicação das fraturas com zonas superficiais de recarga.

Costa (1965) definiu três tipos de fraturas denominadas de angular, transversal e longitudinal, sendo que às duas últimas estavam associadas as maiores vazões dos poços. Costa (1980) reinterpretou o significado das fraturas transversais que tendem a ser abertas porque são paralelas ao esforço compressivo (fraturas de tração), enquanto que as angulares correspondem às de cisalhamento e formam ângulo de $60^{\circ}$ entre si, tendo como bissetriz do ângulo de maior compressão. As fraturas longitudinais teriam sua origem relacionada a movimentos epirogenéticos.

A existência de planos de descontinuidade abertos pode ser considerado o principal condicionante da quantidade e capacidade de exploração das águas subterrâneas (Costa 1980). As fraturas possuem aberturas que não passam de alguns centímetros, sendo mais comuns os valores da ordem de milímetros ou décimos de milímetros (Custódio \& Llamas 1996). Como a condutividade hidráulica é proporcional a abertura da fratura elevada a um potência de 3 , a diferença de condutividade entre rochas com abertura de fratura de dezenas de milímetros e daquelas da ordem de milímetros é bastante significativa (Freeze \& Cherry 1979).

Neste sentido, a caracterização estrutural em estudos de hidrogeologia tem buscado compreender a gênese do fraturamento para caracterizar as fraturas abertas e lineamentos associados (Bertachini 1987, Menegasse 1991, Cavalcante 1990, Fernandes 1997). O contexto geológico e tectônico exerce forte influência sobre a gênese do fraturamento e portanto, sobre a formação dos aqüíferos fraturados. Estudos mais recentes enfatizam a necessidade do conhecimento da neotectônica, normalmente de caráter rúptil que não só reativa estruturas préexistentes, mas também gera novas estruturas (Silva 1994, Fernandes 1997). Entretanto, no Brasil o conhecimento sobre a tectônica e a deformação recentes é ainda muito pequeno.

Os diversos estudos realizados têm indicado que a compreensão dos condicionantes hidrogeológicos da produtividade dos poços em meios fraturados são uma interação da história tectônica da área, responsável pelo fraturamento e deformação das rochas, e os processos intempéricos, no qual o clima desempenha fator fundamental. 


\subsection{TRABALHOS ANTERIORES}

O primeiro estudo sobre a hidrogeologia do Distrito Federal (DF) foi realizado por Romano \& Rosas (1970), que buscaram sintetizar o conhecimento então disponivel sobre os aqüiferos da região. Os autores comparam os custos econômicos entre a captação de água superficial e subterrânea para o abastecimento da cidade de Sobradinho.

A Planidro (1970) reconhece a necessidade de estudos sistemáticos especialmente com relação aos aqüiferos mais profundos que ocorrem na região. Destaca que essa água poderia ser importante alternativa para indústrias e hospitais fora do alcance do sistema público e em áreas agricolas em que o uso das águas superficiais não fosse econômico.

A fim de avaliar a potencialidade da água subterrânea como alternativa complementar ao abastecimento urbano, Costa (1975) buscou caracterizar hidrogeologicamente as regiões das cidades de Sobradinho, Taguatinga, Ceilândia e Gama. Este representa o primeiro estudo de detalhe feito no DF. Com relação à região de Sobradinho, conclui que não há possibilidades de aumentar as descargas das captações então utilizadas, e nem adotar um sistema de explotação através de poços tubulares.

A escassez de estudos sobre as águas subterrâneas durante a década de 70 até meados de 80 , reflete diretamente a sua pequena importância como alternativa de abastecimento, que privilegiava as águas superficiais.

Em 1987 foi realizado através da CAESB (Companhia de Água e Esgotos de Brasilia) o Inventário Hidrogeológico do DF (Barros 1987). Este estudo apresenta grande importância pois produziu um cadastro das obras de captação de água subterrânea (poços e fontes), caracterizando a qualidade técnica destas obras, os principais domínios e sistemas aqǘferos, e a qualidade da água a nivel regional. Ele representou o primeiro estudo de referência sobre a hidrogeologia do DF e produziu o primeiro mapa hidrogeológico. $O$ estudo conclui que a vocação hidregeológica da região é restrita (pequena a média).

O estudo de Santos (1989) apresenta caráter complementar ao de Barros (1987), buscando uma melhor caracterização do padrão de fraturamento da região, das características geológicas dos sedimentos de cobertura e da composição química das águas subterrâneas.

A partir dos anos 90 a água subterrânea passou a desempenhar papel importante no abastecimento público no DF. A expansão de núcleos urbanos consolidados, o surgimento dos condomínios e a utilização pela CAESB de poços tubulares de forma complementar para abastecimento de algumas cidades, demonstrou que o conhecimento sobre $\circ$ potencial hidrogeológico da região e dos subsistemas aqüiferos da região precisava ser aprimorado. 
Barros (1994) reconhece o papel da água subterrânea como importante fonte para se complementar a demanda por água, apresentando uma sintese do estudo de Barros (1987). Em 1998 foi realizado o "Inventário Hidrogeológico e dos Recursos Hídricos Superficiais do Distrito Federal". Neste estudo Campos \& Freitas-Silva (1998) apresentam um novo mapa hidrogeológico e uma nova classificação dos domínios, sistemas e subsistemas aqüíferos, e a quantificação das reservas hidricas subterrâneas.

A tabela 4 apresenta os principais domínios e sistemas aqüiferos identificados no DF mostrando as unidades similares. É possível observar que em Barros $(1987,1994)$ a definição dos sistemas aqüiferos se baseia essencialmente nas unidades litoestratigráficas e nos principais tipos litológicos associados. Campos \& Freitas-Silva (1998) acrescentam a estes parâmetros, a análise estatística de vazões para o aqüífero fraturado, e com relação ao domínio poroso, valores de condutividade hidráulica e transmissividade. 


\begin{tabular}{|c|c|c|c|c|c|}
\hline $\begin{array}{l}\text { Domínio } \\
\text { Aqüífero }\end{array}$ & \multicolumn{2}{|c|}{$\begin{array}{c}\text { Sistema } \\
\text { Aqüifero/Unidade } \\
\text { Litoestratigráfica }\end{array}$} & Barros (1987) & \multicolumn{2}{|c|}{ Campos \& Freitas-Silva (1998) } \\
\hline \multirow{5}{*}{ 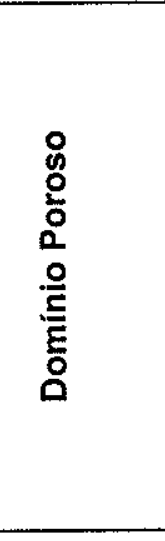 } & \multirow{5}{*}{\multicolumn{2}{|c|}{$\begin{array}{l}\text { Manto } \\
\text { de } \\
\text { Cobertura }\end{array}$}} & $\begin{array}{l}\text { Subsistema Rochas do Quatemário: } \\
\text { aluviōes e subordinadamente colúvios }\end{array}$ & & $\begin{array}{l}\text { Vazão média } \\
\left(\mathrm{m}^{3} / \mathrm{h}\right)\end{array}$ \\
\hline & & & Subsistema Cobertura do Terciário- & $\begin{array}{c}\text { Sistema P1 } \\
\text { latossolo vermelho-amarelo, } \\
\text { textura arenosa e areias } \\
\text { quartzosas } \\
\end{array}$ & \multirow{4}{*}{$<0,80$} \\
\hline & & & $\begin{array}{l}\text { Quaternário: lateritas e latossolos } \\
\text { (vazóes inferiores a } 1,00 \mathrm{~m}^{3} / \mathrm{h} \text { ) }\end{array}$ & $\begin{array}{c}\text { Sistema P2 } \\
\text { latossolo vermelho arenoso a } \\
\text { siltoso }\end{array}$ & \\
\hline & & & & $\begin{array}{l}\text { Sistema P3 } \\
\begin{array}{l}\text { latossolo vermelho argiloso e } \\
\text { localmente cambissolo }\end{array}\end{array}$ & \\
\hline & & & & $\begin{array}{c}\text { Sistema P4 } \\
\text { cambissolos litólicos e litossolos }\end{array}$ & \\
\hline \multirow{10}{*}{ 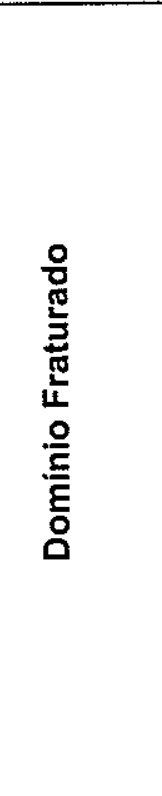 } & \multirow{6}{*}{$\begin{array}{l}\text { Sistema } \\
\text { Paranoá }\end{array}$} & PPC & Subsistema Calcários/Metarritmito-Ardósia & $\begin{array}{c}\text { Subsistema PPC } \\
\text { metassiltitos e metargilitos com } \\
\text { lentes de calcários e quartzito }\end{array}$ & 3,10 \\
\hline & & $R_{4}$ & Subsistema Metarritmito & $\begin{array}{c}\text { Subsistema } \mathrm{R}_{4} \\
\text { metarritmito argiloso }\end{array}$ & 6,15 \\
\hline & & $\mathrm{Q}_{3}$ & Subsistema Quartzito & \multirow{2}{*}{$\begin{array}{l}\text { Subsistema } \mathrm{R}_{3} / \mathrm{Q}_{3} \\
\text { metarritmitos arenosos e } \\
\text { quartitos }\end{array}$} & \multirow{2}{*}{12,2} \\
\hline & & $\mathrm{R}_{3}$ & Subsistema Metarritmito & & \\
\hline & & A & Subsistema Metarritmito-Ardósia & $\frac{\text { Subsistema } A}{\text { ardósias }}$ & 4,39 \\
\hline & & $\mathrm{S}$ & & $\begin{array}{c}\text { Subsistema S/A } \\
\text { metassiltitos e ardósias }\end{array}$ & 12,70 \\
\hline & \multirow{2}{*}{\multicolumn{2}{|c|}{ Sistema Canastra }} & & $\frac{\frac{\text { Subsistema F }}{\text { flitos }}}{}$ & 7,50 \\
\hline & & & filitos e quartzitos & $\begin{array}{l}\text { Subsistema } F / Q / M \\
\text { filitos com lentes de mármores, } \\
\text { quartzitos e calcifilitos }\end{array}$ & 33,00 \\
\hline & \multicolumn{2}{|c|}{ Sistema Bambuí } & +2 & $\begin{array}{l}\text { metassiltitos, metassiltitos } \\
\text { argilosos e bancos de arcóseos }\end{array}$ & 5,21 \\
\hline & \multicolumn{2}{|c|}{ Sistema Araxá } & xistos e filitos & $\begin{array}{l}\text { xistos com lentes de quartzitos } \\
\text { ou quartzo xistos }\end{array}$ & 3,15 \\
\hline
\end{tabular}

Tabela 4. Resumo das classificações dos domínios, sistemas e subsistemas aqüiferos do Distrito Federal propostas por Barros (1987) e Campos \& Freitas-Silva (1998). 


\subsection{DEFINIÇÃo E CLASSIFICAÇÃo dOS AQÜÍFEROS}

A área de estudo se caracteriza geologicamente por apresentar rochas metamórficas (metassedimentos) recobertas por espesso manto de intemperismo. Dentro desse contexto, podem ser diferenciados dois grandes grupos de aqüiferos, que correspondem aos tipos clássicos que são o Domínio Poroso e o Dominio Fraturado. Embora formem sistemas aqüiferos com condições de circulação e armazenamento de águas distintos, encontram-se hidraulicamente conectados.

\subsubsection{DomínIO PoRoso}

Corresponde na região estudada ao manto de intemperismo e, de forma mais restrita, aos aluviōes, que caracterizam-se como meios geológicos inconsolidados, essencialmente porosos. Neles a água está contida nos espaços vazios, que correspondem aos poros localizados entre os grãos que compõem a litologia. A porosidade é função basicamente do formato, arranjo e o grau de compactação e cimentação dos grãos.

Este sistema aqüifero compõem o sistema de águas subterrâneas rasas. Apresenta importância local significativa, sendo responsável pelo abastecimento principalmente da população rural e de alguns condominios da região, através de poços rasos e subordinadamente, através de fontes.

O manto de intemperismo ou regolito da região é representado pelos solos e saprolitos que recobrem a rocha sã. $O$ termo saprolito empregado designa o solo formado pela desagregação in situ das rochas, que mantém preservados vestígios da estrutura e da textura da rocha original, apresentando minerais primários intensamente alterados.

Os solos e saprolitos constituem um meio não consolidado formando um sistema contínuo de grande extensão e continuidade lateral recobrindo praticamente $99 \%$ da área estudada. São aqüiferos livres e, de forma mais restrita, supensos.

Em continuidade hidráulica e portanto, integrando este sistema aqüifero, ocorrem os aluviões que são muito pouco expressivos na área e não têm praticamente nenhuma participação no abastecimento da população através de água subterrânea. Estão restritos aos vales dos ribeirões da região, sendo o mais importante aquele que acompanha a calha de drenagem do ribeirão Sobradinho. Os aluviões estão associados a solos hidromórficos principalmente na porção norte da bacia. São limitados lateralmente e pouco espessos, apresentando sedimentos mal selecionados, com granulometria de argila até areia média. 
O manto de intemperismo desempenha importante papel dentro do contexto hidrogeológico da área de estudo. A zona não saturada é muito importante para a recarga do aqüifero freático e atua como proteção do aqüifero à contaminação antrópica. Além disso, a zona saturada do saprolito, por encontrar-se em contato direto sobre a rocha sã, exerce importante função nas condições de recarga das fraturas, que compõem o aqüífero fraturado subjacente. Finalmente o manto de intemperismo, por sua grande extensão e continuidade, é responsável pela manutenção da perenidade das drenagens durante o período de seca.

A formação do manto de intemperismo na área é função do clima quente e úmido, que vem atuando em diferentes periodos na região, do substrato geológico e da tectônica atuante na área. Os processos de lixiviação e laterização, associados a hidratação e hidrólise de minerais primários, contribuem para a formação de argilominerais e lateritas, e a evolução do perfil de intemperismo. A presença de zonas fraturadas interconectadas, possivelmente apresenta grande importância no avanço do intemperismo químico na rocha sã.

A caracterização do perfil de intemperismo na área, estabelecido principalmente a partir dos perfis litológicos dos poços profundos, mostra forte controle do tipo litológico subjacente, que influi diretamente na espessura (tabela 5) e nas caracteristicas granulométricas e mineralógicas, que controlam as propriedades hidráulicas destes meios.

Tabela 5. Variações de espessura no manto de intemperismo (solo e saprolito) em função do substrato geológico.

\begin{tabular}{|c|c|c|c|c|c|}
\hline Substrato geológico & Espessura & $\begin{array}{c}\text { Minima } \\
(\mathbf{m})\end{array}$ & $\begin{array}{c}\text { Média } \\
(\mathbf{m})\end{array}$ & $\begin{array}{c}\text { Máxima } \\
(\mathbf{m})\end{array}$ & Número de poços \\
\hline \multirow{3}{*}{$\begin{array}{c}\text { Metarritmito Arenoso } \\
\left(\mathbf{R}_{3}\right)\end{array}$} & Solo & 8 & 14,0 & 18 & 3 \\
\cline { 2 - 6 } & Saprolito & 30 & 44,7 & 56 & 3 \\
\cline { 2 - 6 } & Solo + saprolito & 38 & 58,7 & 72 & 3 \\
\hline \multirow{2}{*}{$\begin{array}{c}\text { Quartzito } \\
\left(\mathbf{Q}_{3}\right)\end{array}$} & Solo & 1 & 7,2 & 24 & 16 \\
\cline { 2 - 6 } & Saprolito & 1,5 & 8,2 & 18 & 16 \\
\cline { 2 - 6 } & Solo + saprolito & 3 & 12,5 & 33 & 23 \\
\hline \multirow{3}{*}{$\begin{array}{c}\text { Metarritmito Argiloso } \\
\left(\mathbf{R}_{4}\right)\end{array}$} & Solo & 3 & 22,5 & 84 & 17 \\
\cline { 2 - 6 } & Saprolito & 12 & 48,8 & 93 & 10 \\
\cline { 2 - 6 } & Solo + saprolito & 30 & 83,8 & 186 & 12 \\
\hline \multirow{3}{*}{$\begin{array}{c}\text { Psamo-Pelito Carbonatada } \\
\text { (PPC) }\end{array}$} & Solo & 3 & 20,1 & 45 & 12 \\
\cline { 2 - 6 } & Saprolito & 3 & 21,8 & 45 & 14 \\
\cline { 2 - 6 } & Solo + saprolito & 9 & 46,6 & 148 & 19 \\
\hline
\end{tabular}

As unidades $Q_{3}$ (Quartzito Médio) e $R_{3}$ (Metarritmito Arenoso) do Grupo Paranoá sustentam as porções topograficamente mais elevadas da área de estudo. Como nestas unidades a presença de termos psamíticos, principalmente quartzitos, é muito significativa, o manto de intemperismo é menos desenvolvido, quando comparado àquele que ocorre nas 
regiões de encosta e de vale, associado às unidades de caráter mais pelítico (unidades Metarritmito Argiloso e Psamo-Pelito Carbonatada).

O regolito associado à unidade $Q_{3}$ é relativamente menos profundo, com espessura média de $12,5 \mathrm{~m}$, enquanto que aquele associado à unidade $R_{3}$, em função da significativa presença de niveis peliticos favorece o desenvolvimento de um manto de intemperismo mais espesso, com média de $58,7 \mathrm{~m}$.

Os solos associados às unidades $R_{3}$ e $Q_{3}$ são representados, predominantemente, por latossolos vermelhos escuros a marrons com 1 até $24 \mathrm{~m}$ de espessura e localmente ocorrem solos arenosos. Este último tipo de solo é correlacionável às areias quartzosas descritas pela EMBRAPA (1978) e são resultantes diretamente da desagregação dos quartzitos. Estes solos apresentam textura arenosa a siltosa e de forma mais restrita, argilosa a siltosa. Os solos que se desenvolvem sobre as chapadas são predominantemente residuais e naqueles associados aos quartzitos o processo de laterização, em geral, é incipiente.

Os saprolitos associados à unidade $Q_{3}$ apresentam de 3 a $33 \mathrm{~m}$ de espessura com valor médio de $8,2 \mathrm{~m}$. Apresentam-se freqüentemente com cor bege sendo bastante friáveis. $A$ distinção entre níveis de rocha sã, decomposta (saprolito) e solo é freqüentemente bem definida. Os saprolitos da unidade $R_{3}$ são mais espessos com média de $44,7 \mathrm{~m}$, sendo comuns niveis intensamente laterizados.

O conjunto solo e saprolito nestes locais apresenta granulometria essencialmente arenosa a siltosa, o que reflete em condutividade hidráulica relativamente elevada. A Planidro (1970) obteve uma condutividade hidráulica de $10^{-4} \mathrm{~cm} / \mathrm{s}$, equivalente a areia fina, em manto de desagregação de quartzito de $24 \mathrm{~m}$ na região do ribeirão Corguinho, próximo à área de estudo. As areias do regolito associadas aos quartzitos são extraidas para a construção civil na área dos condomínios, no $\mathrm{km} \mathrm{1,5}$ da DF-150. Como este manto de intemperismo apresenta boas condições de permeabilidade e ocorre nas regiões mais elevadas, a sua participação na recarga dos aqüiferos da região é muito importante.

Um aspecto interessante a se destacar, especialmente na região onde o substrato é representado pela unidade $Q_{3}$, é que apesar de ocupar uma área com as cotas topográficas mais elevadas, o nível freático é bastante raso, por volta de $4 \mathrm{~m}$. Desta forma, o embasamento, relativamente menos permeável que o manto de intemperismo, funciona como barreira, dificultando a infiltração vertical da água. Nas regiões mais elevadas onde ocorrem os metarritmitos, o regolito é mais espesso e o nivel de água mais profundo, chegando a valores superiores a $15 \mathrm{~m}$. 
As litologias mais susceptiveis aos processos de intemperismo químico na área de estudo são os metargilitos e metassiltitos. Por isso, o manto de intemperismo associado ao substrato formado essencialmente por rochas pelíticas é significativamente mais profundo. As transições entre solo/saprolito e saprolito/rocha são muitas vezes imprecisos e de difícil definição. Este manto de intemperismo espesso ocorre nas regióes de encosta e de vale da bacia, e corresponde à ocorrência das unidades Metarritmito Argiloso $\left(R_{4}\right)$ e Psamo-Pelito-Carbonatada (PPC). As espessuras médias do regolito sobre as unidades $R_{4}$ e PPC são respectivamente, de 83,8 e $46,6 \mathrm{~m}$.

Nos perfis no qual foi possível distinguir saprolito e solo, os solos apresentam espessuras que variam de 3 até $84 \mathrm{~m}$, sobre a unidade $R_{4}$, e de 3 a $45 \mathrm{~m}$, sobre a unidade PPC. São latossolos vermelho escuros e de forma subordinada, amarelos a marrons, de textura argilosa ou argilosa-siltosa. A origem dos solos do DF, especialmente em regiões de declividades mais acentuadas tem sido bastante discutida. Alguns estudos consideram os solos como predominantemente residuais (Mendonça et al. 1994). Contudo, têm sido identificados em vários locais a associação de solos residuais e transportados (Martins et al. 1994, Mortari 1994, Blanco 1995).

Independentemente da sua origem, estes solos apresentam em geral textura silto-argilosa com permeabilidade e porosidade elevadas. Mortari (1994) considera que a estrutura "castelo de cartas", observada nestes solos, é mantida pelas cimentações que promovem a formação de estrutura granular, apesar da matriz argilosa, com comportamento em termos de infiltração similar aos solos granulares $\left(10^{-3}\right.$ a $\left.10^{-4} \mathrm{~cm} / \mathrm{s}\right)$. Esta estrutura, comumente observada em solos do DF, é responsável pelo fenômeno da colapsividade, que obriga, no caso da perfuração de poços profundos, o revestimento até profundidades bastante significativas. Estudo geotécnico de solo, recobrindo metarritmito argiloso na região de Sobradinho, indicou frações de argila, silte e areia respectivamente, de $50,5 \%, 9,5 \%$ e $40 \%$, com porosidade de $57,5 \%$ e condutividade hidráulica entre $10^{-5}$ a $2,4 \times 10^{-4} \mathrm{~cm} / \mathrm{s}$ (Mortari 1994).

Os saprolitos associados às unidades $R_{4}$ e PPC apresentam espessuras bastante variáveis (tabela 5), em função do grau de intemperismo e tipo litológico do substrato. Quando existem camadas expressivas de quartzitos, rocha mais resistente aos agentes intempéricos, o saprolito é, em geral, menos espesso e o contato saprolito/rocha é bem definido. Quando o substrato é composto por metapelitos a transição saprolito/rocha não é bem definida, e como são rochas muito susceptíveis ao intemperismo, os saprolitos são mais espessos. Estas feições determinam significativas variações laterais dos saprolitos na área. 
Em pacotes de metarritmitos, em que se alternam níveis pelíticos e psamiticos, as variações verticais e horizontais na textura dos saprolitos são também significativas, desde arenosa até argilosa. Predomina, de forma geral, a textura siltico-argilosa, em função do caráter pelítico das unidades $\mathrm{R}_{4}$ e PPC. Apesar disso, os saprolitos da região apresentam variados graus de laterização e diferentes características de permeabilidade. Possivelmente a condutividade hidráulica dos saprolitos de quartzitos é elevada. Contudo, naqueles originários dos metapelitos, que apresentam elevado grau de laterização, a permeabilidade deve ser bastante baixa.

Na região de Sobradinho, a cobertura dos metarritmitos apresenta sempre intercalações argilosas e, em geral, laterizados. Esta laterização, quando incipiente, não altera as condições de permeabilidade do manto. Porém em muitos locais ela é intensa, produzindo uma crosta rígida ferruginosa que praticamente impermeabiliza o material afetado pelo processo (Costa 1975).

Dois poços profundos na área de estudo explotam o aqüifero poroso e apresentaram espessuras para o manto de intemperismo de $152 \mathrm{~m}$ (P49) e $60 \mathrm{~m}$ (P13). As baixas vazão (0,88 $\mathrm{m}^{3} / \mathrm{h}$ ) e vazão específica $\left(0,023 \mathrm{~m}^{3} / \mathrm{h} . \mathrm{m}\right)$ do poço $\mathrm{P} 13$ estão associadas a solo argiloso, desenvolvido sobre a unidade $R_{4}$. Em manto de alteração da unidade PPC, na qual a participação de quartzitos é mais expressiva, o poço $P 49$ possui vazão de $7,9 \mathrm{~m}^{3} / \mathrm{h}$ e vazão especifica de $0,208 \mathrm{~m}^{3} / \mathrm{h} . \mathrm{m}$.

$\mathrm{Na}$ área de estudo não existem informações de perfis geológicos de poços profundos na região onde afloram os filitos pertencentes ao Grupo Canastra. Observações de campo indicam que a maior parte desta área é recoberta por um manto espesso, comparável àquele que ocorre sobre as litologias do Grupo Paranoá. Próximo ao rio São Bartolomeu o relevo então plano, passa a exibir morros côncavo-convexos e vales encaixados. Nesta região os solos são pedregosos e bastante rasos, correspondendo aos cambissolos descritos pela EMBRAPA (1978). Em função da sua pequena profundidade e do substrato de caráter argiloso, possivelmente o manto de intemperismo deve apresentar baixa permeabilidade.

\subsubsection{DomínIo FRATURADO}

As rochas metassedimentares dos Grupos Paranoá e Canastra representam meios tipicamente fraturados, nos quais o fluxo das águas subterrâneas está condicionado à ocorrência de descontinuidades físicas nas rochas. Os espaços intergranulares destas rochas foram fechados durante o metamorfismo e são praticamente insignificantes. Os condicionantes 
em subsuperfície do fluxo da água são representados principalmente por fraturas, responsáveis pela permeabilidade secundária destas rochas.

Com base nas principais unidades litoestratigráficas e considerando critérios litológicos e as características hidráulicas (vazão e vazão específica) dos poços profundos, foi possível definir na área de estudo 2 sistemas aqüiferos: Sistema Paranoá e Sistema Canastra (figura 12). O Sistema Paranoá foi subdividido em 4 subsistemas. No sistema Canastra não foram cadastrados poços profundos e por isso, a sua caracterização se baseia em estudos hidrogeológicos realizados em outras áreas.

Em geral os valores de vazão específica dos poços em aqüiferos fraturados apresentam distribuição log-normal ao longo da maior parte dos intervalos (Banks et al. 1994 apud Fernandes 1997). Como a média da vazão especifica é significativamente alta devido à existência de alguns poços com altas produtividades, a mediana, quando comparada com a média, é mais representativa (Fernandes 1997). Por isso optou-se, na caracterização dos parâmetros hidráulicos dos poços dos subsistemas aqüíferos, pela utilização da média das vazões e mediana das vazões específicas.

O domínio fraturado na região apresenta-se tipicamente anisotrópico e heterogêneo, que é materializado pelas significativas variações nas vazões entre poços separados por distâncias de algumas dezenas de metros. Estes aqüiferos na área são condicionados essencialmente pela presença de zonas fraturadas e formam aqüiferos livres, com extensão lateral e vertical variáveis.

As águas subterrâneas deste domínio representam importante fonte de abastecimento para uma significativa parte da população da bacia, através de poços profundos, apesar da grande variação de vazões obtidas e mesmo poços secos.

\subsubsection{Sistema PARANOÁ}

\section{A) SUbSISTEMA METARRITMITo ARENOSO}

Este subsistema aqüífero só é explotado na região nordeste da área de estudo, na região do Domo de Sobradinho, no qual ocorre a unidade Metarritmito Arenoso $\left(R_{3}\right)$ do Grupo Paranoá. Foram cadastrados apenas 4 poços neste subsistema, dos quais um deles foi abandonado com vazão de $5 \mathrm{~m}^{3} / \mathrm{h}$, considerada insuficiente pelo contratante da obra. Como não foram observados afloramentos desta unidade na área estudada, em função do manto de cobertura, a sua caracterização se baseia nos perfis de 3 poços. 
Litologicamente este subsistema é constituido pela alternância de niveis centimétricos de metassiltitos, metassiltitos argilosos e metargilitos, e niveis centimétricos a métricos de quartzitos finos. A fração pelítica apresenta cor cinza, quando fresca, e branca a rósea, devido à alteração, sendo localmente preta quando rica em matéria orgânica. Os quartzitos são, em geral, bastante silicificados, laminados, apresentando colorações cinza, esverdeada e rósea. Localmente apresentam granulação média a grossa, e podem formar bancos de até $18 \mathrm{~m}$ de espessura.

A vazão média dos poços deste subsistema é de $26,7 \mathrm{~m}^{3} / \mathrm{h}$ (tabela 6 ). A mediana da vazão específica é de $0,80 \mathrm{~m}^{3} / \mathrm{h}$.m. Os poços apresentam profundidades entre 154 e $186 \mathrm{~m}$, com média de $173,5 \mathrm{~m}$

Tabela 6. Parâmetros hidráulicos dos poços do subsistema aqüifero Metarritmito Argiloso (* foram considerados apenas pocos com perfis construtivo e litológico completos

\begin{tabular}{|c|c|c|c|c|c|c|c|c|}
\hline $\begin{array}{c}\text { Subsistema } \\
\text { Aqüifero } \\
\text { Metarritmito } \\
\text { Arenoso }\end{array}$ & $\begin{array}{c}\text { Parâmetros } \\
\text { hidrodinâmicos }\end{array}$ & Mínima & Média & Máxima & Mediana & $\begin{array}{c}\mathbf{N}^{0} \text { de poços em } \\
\text { funcionamento* }\end{array}$ & $\begin{array}{c}\mathbf{N}^{*} \text { de poços } \\
\text { desativados }^{*}\end{array}$ \\
\cline { 2 - 7 } & $\begin{array}{c}\text { Vazão } \\
\text { Vazecífica } \\
\left(\mathrm{m}^{3} / \mathrm{h} . \mathrm{m}\right)\end{array}$ & 0,41 & 0,89 & 1,46 & 0,80 & 3 & 1 \\
\hline
\end{tabular}

Assim como ocorre no Subsistema Quartzito, muitas vezes as entradas de água nos poços são marcadas por niveis ricos em óxido de ferro descritos em amostras de calha. A formação destes óxidos possivelmente se relaciona à infiltração nas fraturas de água associada a horizontes lateríticos, sendo o ferro precipitado posteriormente.

\section{B) SUBSISTEMA QUARTZITO}

Este subsistema aqüifero ocupa as áreas mais elevadas da chapada da Contagem e corresponde às litologias da unidade $Q_{3}$ do Grupo Paranoá, denominada de Quartzito Médio. É constituído por tipos litológicos com caráter predominantemente psamítico.

Apresenta grande importância na área de estudo, pois corresponde aos locais onde existe grande demanda por água subterrânea, já que são áreas de topografia plana que favorece a ocupação antrópica e onde tem havido um grande adensamento populacional nos últimos anos

Foram reconhecidos nesta unidade aqüifera, do ponto de vista litológico, quartzitos brancos a marrons, de granulação fina a média, em geral, bastante silicificados e muitas vezes friáveis, quando perdem a cimentação. $\mathrm{Em}$ afloramentos observa-se o aspecto maciço dessas rochas, a dificuldade em reconhecer $o$ acamamento sedimentar $\mathrm{e} o$ intenso fraturamento destas litologias. Quando não alterados estes quartzitos apresentam cores que variam do cinza claro a 
escuro. Em niveis mais intemperizados apresentam cor rósea chegando a vermelha, devido à formação de fina camada de óxidos de ferro.

Localmente ocorrem lentes de metarritmitos representados por niveis de metassiltitos e metargilitos brancos a vermelhos, finamente laminados intercalados a níveis decimétricos de quartzitos. A espessura destas lentes varia desde decimétrica a métrica, tendo sido identificada uma lente com $9 \mathrm{~m}$ de espessura.

Embora não tenha sido possivel definir a espessura total deste subsistema, é possivel estimar um valor médio de $130 \mathrm{~m}$, pelo menos para a região noroeste da área de estudo, na qual se concentram os poços que explotam esta unidade. E importante ressaltar que estes valores são bastante superiores a espessura de $70 \mathrm{~m}$ proposta regionalmente para a unidade $Q_{3}$ (Campos \& Freitas-Silva 1998).

O processo de intemperismo químico intenso atuando sobre os quartzitos resulta muitas vezes na destruição da sua cimentação formando níveis friáveis e inconsolidados. Por isso freqüentemente os poços são revestidos e apresentam filtro e pré-filtro, mesmo após ter sido atingida a rocha sã.

Os poços que explotam este subsistema apresentaram média de vazões de $8,7 \mathrm{~m}^{3} / \mathrm{h}$ e profundidades entre 0 e $198,5 \mathrm{~m}$, com média de $112 \mathrm{~m}$. A incidência de poços secos neste subsistema é praticamente nula, embora tenham sido identificados poços com baixas vazões, em torno de $1 \mathrm{~m}^{3} / \mathrm{h}$. A mediana das vazões específicas deste subsistema é de $0,24 \mathrm{~m}^{3} / \mathrm{h} . \mathrm{m}$ (tabela 7).

Tabela 7. Parâmetros hidráulicos dos poços do subsistema aqüifero Quartzito ( ${ }^{*}$ foram considerados apenas poços com perfis construtivo e litológico completos).

\begin{tabular}{|c|c|c|c|c|c|c|c|}
\hline \multirow{3}{*}{$\begin{array}{c}\text { Subsistema } \\
\text { Aqüifero } \\
\text { Quartzito }\end{array}$} & $\begin{array}{c}\text { Parâmetros } \\
\text { hidrodinâmicos }\end{array}$ & Mínima & Média & Máxima & Mediana & $\begin{array}{l}\mathrm{N}^{0} \text { de poços em } \\
\text { funcionamento }\end{array}$ & $\begin{array}{c}N^{0} \text { de poços } \\
\text { desativados } \\
\star\end{array}$ \\
\hline & $\operatorname{Vazão}\left(\mathrm{m}^{3} / \mathrm{h}\right)$ & 1,0 & 8,7 & 20,3 & - & \multirow[b]{2}{*}{24} & \multirow[b]{2}{*}{0} \\
\hline & $\begin{array}{c}\text { Vazão especifica } \\
\left(m^{3} / h . m\right)\end{array}$ & 0,01 & 0,86 & 7,25 & 0,24 & & \\
\hline
\end{tabular}

\section{C) SUBSISTEMA METARRITMITO ARgILOSO}

Este subsistema ocorre na região de encosta, ou seja, na transição entre as porções mais elevadas de chapada (unidades $Q_{3}$ e $R_{3}$ ) e o vale no qual ocorre a unidade PPC. E correlacionável aos litotipos dos metarritmitos argilosos do Grupo Paranoá (unidade $\mathrm{R}_{4}$ ).

o subsistema é representado por um metarritmito bastante homogêneo no qual se alternam níveis centimétricos de metargilitos e metassiltitos com coloração branca, amarela, vermelha e verde e cinza de acordo com o grau de intemperismo. Freqüentemente estas 
litologias apresentam aspecto maciço. Ocorrem intercalados a este pacote lentes ou níveis de quartzitos finos, localmente médios, muitas vezes friáveis, de cores marrom, branco e cinza, com espessuras centimétricas a até $2 \mathrm{~m}$.

A grande predominância da fração pelítica sobre os quartzitos e a localização topográfica, representaram importantes critérios para a separação, na área estudada, das litologias pertencentes à unidade PPC.

Cinco poços observados neste subsistema atingiram os quartzitos pertencentes ao Subsistema Quartzito, o que permitiu determinar uma espessura mínima de $105 \mathrm{~m}$ para a unidade aqüifera. A passagem entre estas unidades apresenta caráter gradacional, caracterizada pelo aumento das intercalações de quartzito nos últimos $10 \mathrm{~m}$ até atingir a unidade $Q_{3}$.

São observados nos poços que atravessam este subsistema as feições de intemperismo químico diferencial pelo qual entre níveis de rochas não alteradas ocorrem níveis, principalmente pelíticos, extremamente alterados. Por isso, os poços construídos são quase que inteiramente revestidos e empregam filtros nos niveis fraturados. A origem do intemperismo químico diferencial, feição freqüentemente observada nos poços do Distrito Federal, ainda não é entendida.

A tabela 8 apresenta os principais parâmetros de vazão e vazão especifica dos poços que explotam o subsistema aqüifero Metarritmito Argiloso e os poços mistos (subsistemas Metarritmito Argiloso e Quartzito). A média de vazão dos poços no subsistema Metarritmito Argiloso é de $4,6 \mathrm{~m}^{3} / \mathrm{h}$ e a mediana da vazão especifica é de $0,08 \mathrm{~m}^{3} / \mathrm{h}$.m. A incidência de poços secos é relativamente elevada, sendo a maior entre os subsistemas aqüiferos estudados. As profundidades dos poços estão entre 100 e $236,9 \mathrm{~m}$, apresentando média de $160 \mathrm{~m}$.

Tabela 8. Parâmetros hidráulicos dos poços dos subsistemas aqüifero Metarritmito Argiloso e misto (Metarritmito Argiloso/Quartzito) (* foram considerados apenas poços com perfis construtivo o litób́co completos).

\begin{tabular}{|c|c|c|c|c|c|c|c|}
\hline $\begin{array}{l}\text { Subsistema } \\
\text { Aqüifero }\end{array}$ & $\begin{array}{c}\text { Parâmetros } \\
\text { hidrodinâmicos }\end{array}$ & Minima & Média & Máxima & Mediana & \begin{tabular}{|c|c|}
$\begin{array}{c}\text { Número de poços } \\
\text { em } \\
\text { funcionamento* }\end{array}$ \\
\end{tabular} & $\begin{array}{c}\text { Número de } \\
\text { poços } \\
\text { desativados* }\end{array}$ \\
\hline \multirow{2}{*}{$\begin{array}{l}\text { Metarritmito } \\
\text { Argiloso }\end{array}$} & Vazão $\left(\mathrm{m}^{3} / \mathrm{h}\right)$ & 1,0 & 4,6 & 14,5 & - & \multirow[t]{2}{*}{ 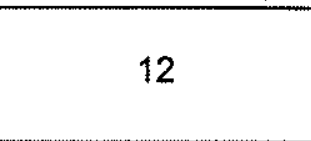 } & \multirow[t]{2}{*}{ ( } \\
\hline & $\begin{array}{c}\text { Vazão específica } \\
\left(\mathrm{m}^{3} / \mathrm{h} . \mathrm{m}\right)\end{array}$ & 0,01 & 0,11 & 0,35 & 0,08 & & \\
\hline \multirow[t]{2}{*}{ Misto } & $\operatorname{Vazão~}\left(\mathrm{m}^{3} / \mathrm{h}\right)$ & 2,1 & 3,6 & 5,4 & - & \multirow[b]{2}{*}{4} & \multirow[b]{2}{*}{1} \\
\hline & $\begin{array}{c}\text { Vazão especifica } \\
\left(\mathrm{m}^{3} / \mathrm{h} . \mathrm{m}\right)\end{array}$ & 0,03 & 0,10 & 0,23 & 0,04 & & \\
\hline
\end{tabular}




\section{D) Subsistema Psamo-Pelito Carbonatado}

Os poços que atravessam este subsistema na área de estudo concentram-se na porção norte da bacia, que corresponde à região do assentamento Sobradinho $\|$ e condomínios próximos. As litologias descritas são correlacionáveis à unidade PPC de topo do Grupo Paranoá.

Este subsistema é representado basicamente por metassiltitos argilosos e metargilitos bastante laminados de colorações branca, marrom, avermelhada e cinza, quando não alterados. São observadas lentes de meta-calcários cinza escuros interdigitadas neste pacote, de espessura métrica atingindo até $20 \mathrm{~m}$. Na transição entre meta-calcários e metapelitos muitas vezes ocorrem meta-margas cinza-esverdeadas.

A característica importante, sob o aspecto litológico, do subsistema aqüifero na área de estudo, é a expressiva participação de quartzitos, que formam niveis ou lentes centimétricas a métricas. Em amostras frescas estas litologias apresentam cores cinza e preta, e quando alteradas são marrons e brancas, apresentando granulação desde fina até microconglomerática. Uma feição distintiva deste subsistema é a presença de níveis decamétricos de quartzitos cinza a negros, grossos a microconglomeráticos, freqüentemente observados em amostras de calha dos poços profundos da área.

Assim como ocorre com no Subsistema Metarritmito Argiloso, são comuns as feições de intemperismo químico diferencial que atuam especialmente nos niveis pelíticos. As profundidades dos poços estão entre 85 e $140 \mathrm{~m}$, com média de $115 \mathrm{~m}$.

A presença de camadas e lentes de quartzitos é responsável pela elevada média de vazão dos poços de $15,7 \mathrm{~m}^{3} / \mathrm{h}$ (tabela 9 ). Entretanto, são também bastante freqüentes os poços secos quando são encontrados apenas tipos pelíticos, ou até mesmo onde se observam espessos niveis de quartzitos. Alguns destes poços secos apresentam perfis litológicos indicando a existência de expressivo fraturamento em quartzitos, que demonstra a importância, na produtividade dos poços, da presença de fraturas abertas e interconectadas com zonas de recarga.

Tabela 9. Parâmetros hidráulicos dos poços do subsistema aqülfero Psamo-Pelito Carbonatado (" foram

\begin{tabular}{|c|c|c|c|c|c|c|c|}
\hline \multirow{3}{*}{$\begin{array}{l}\text { Subsistema } \\
\text { Aqüífero } \\
\text { Psamo*- } \\
\text { Pelito } \\
\text { Carbonatado }\end{array}$} & $\begin{array}{c}\text { Parâmetros } \\
\text { hidrodinâmicos }\end{array}$ & Mínima & Média & Máxima & Mediana & $\begin{array}{c}\text { Número de } \\
\text { poços em } \\
\text { funcionamento* }\end{array}$ & $\begin{array}{c}\text { Número de } \\
\text { poços } \\
\text { desativados* }\end{array}$ \\
\hline & $\operatorname{Vazão~}\left(\mathrm{m}^{3} / \mathrm{h}\right)$ & 6,0 & 15,7 & 30,5 & $=$ & \multirow[b]{2}{*}{15} & \multirow[t]{2}{*}{ 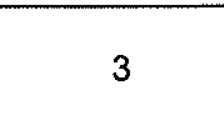 } \\
\hline & $\begin{array}{c}\text { Vazão especifica } \\
\left(\mathrm{m}^{3} / \mathrm{h} . \mathrm{m}\right)\end{array}$ & 0,13 & 0,71 & 1,38 & 0,51 & & \\
\hline
\end{tabular}


Apenas 3 poços na área atravessaram camadas ou lentes de rochas calcárias, indicando que localmente podem se desenvolver na área aqüíferos cárstico-fissurais. As feições de dissolução associada a fraturamento possivelmente são mais importantes nas lentes de maior espessura.

A figura 13 apresenta um perfil hidrogeológico mostrando os subsistemas aqüíferos do Sistema Paranoá.

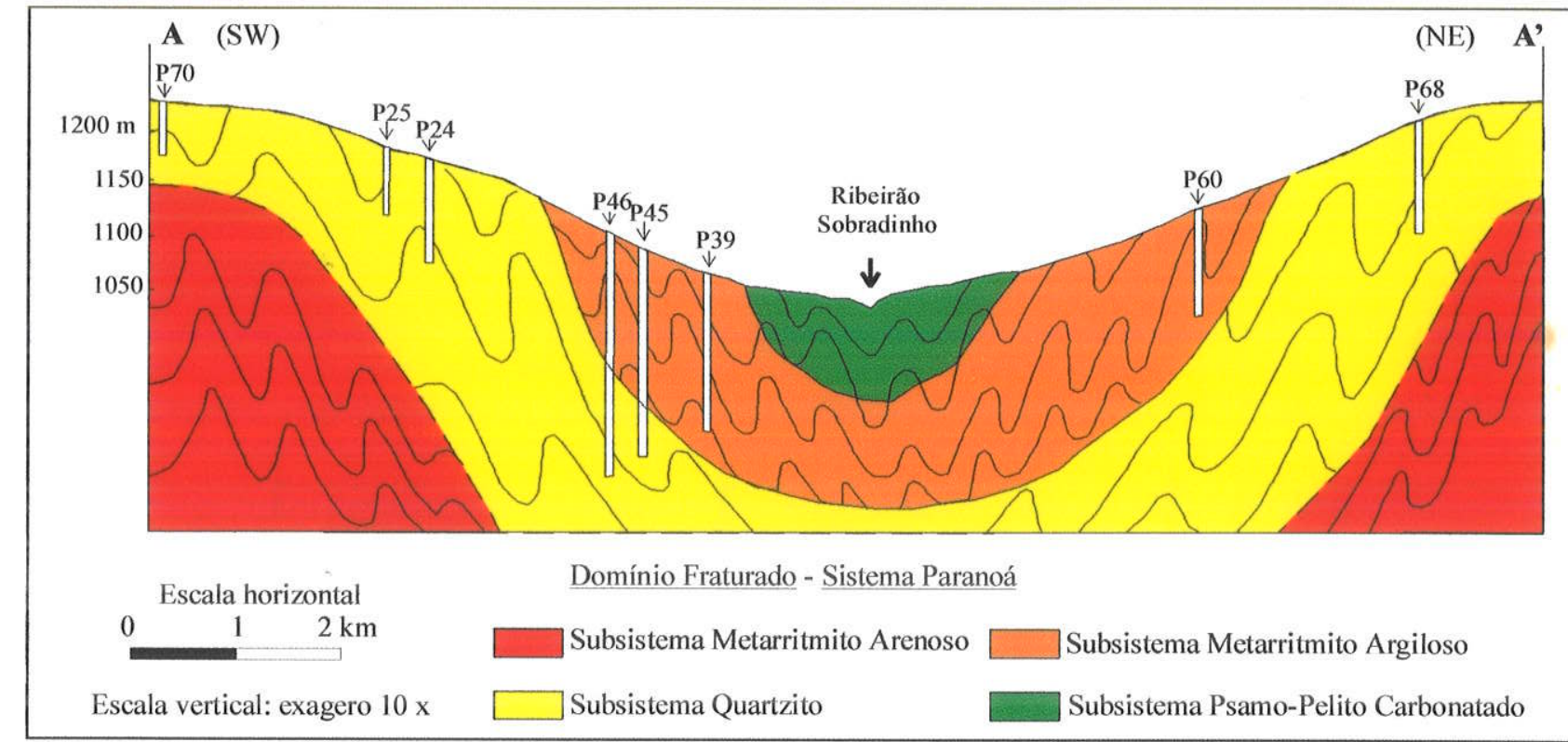

Figura 13. Perfil hidrogeológico esquemático mostrando a estrutura em sinclinal da bacia do ribeirão Sobradinho e os principais subsistemas aqüiferos da área de estudo (a orientação do perfil está indicada na figura 12 , página 53 ).

\subsubsection{Sistema CANASTRA}

É representado litologicamente pelos filitos do Grupo Canastra. Embora na região do DF tenham sido localmente descritas associações de lentes de mármores, calcifilitos e quartzitos interdigitados aos filitos, estes tipos litológicos não foram reconhecidos em afloramentos na área de estudo.

De acordo com Campos \& Freitas-Silva (1998), a vazão média deste subsistema é de 7,5 $\mathrm{m}^{3} / \mathrm{h}$, não sendo rara a incidência de poços com baixas vazões. O relevo em geral acidentado, associado a solos pouco profundos e pouco permeáveis, dificultam a infiltração e a recarga do aqüífero. 


\subsection{Caracterização do Fraturamento}

A análise de fotos aéreas de escala 1:40.000 permitiu a extração de todos os elementos fortemente estruturados que correspondem a segmentos retilíneos de drenagem. Estes elementos apresentam padrões que os distinguem em relação às feições adjacentes e possivelmente refletem descontinuidades em subsuperfície interpretadas como fraturas (figura 14). Na área de estudo existe uma baixa densidade de fraturas em função do espesso manto de intemperismo, que recobre grande parte da região e mascara muitas fraturas.

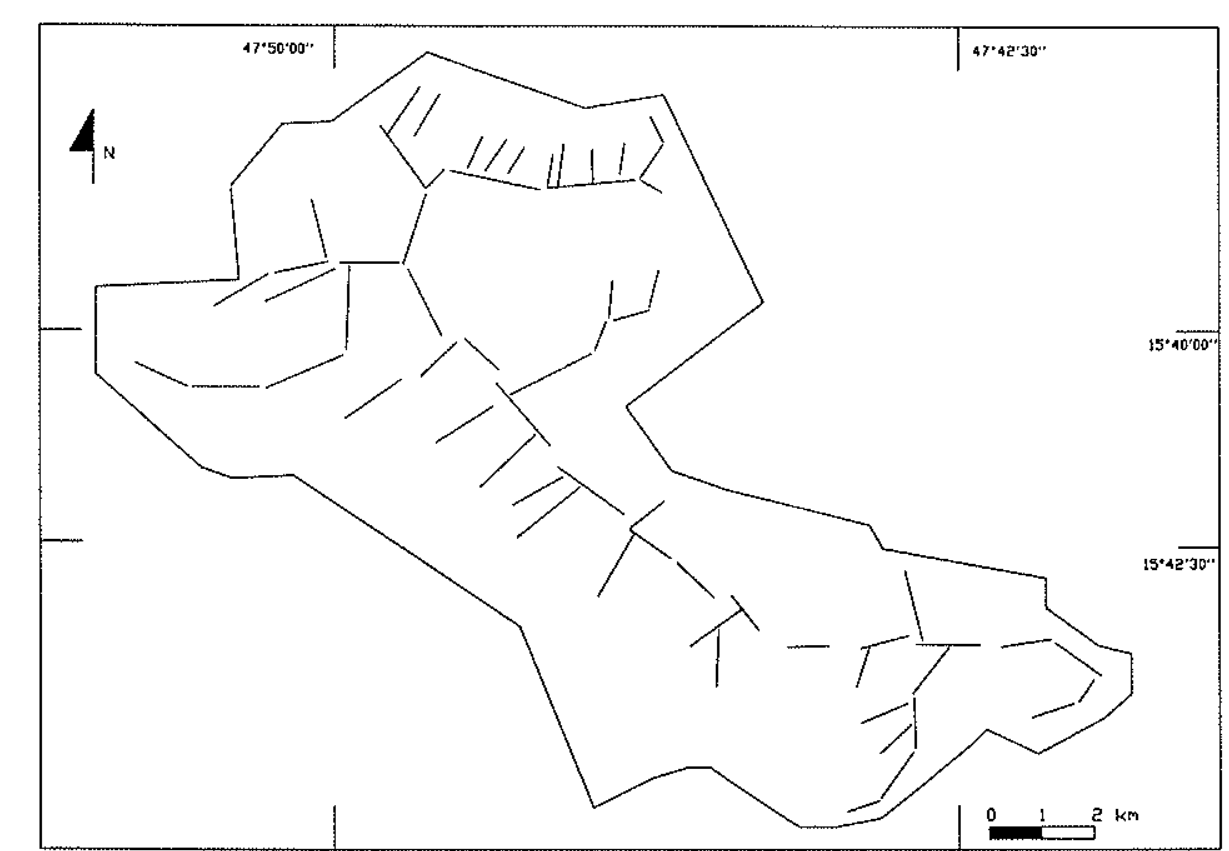

Figura 14. Mapa de lineamentos estruturais extraidos a partir de fotos aéreas de escala 1:40.000.

Devido ao extenso manto de intemperismo que recobre a área com poucas exposições de rochas, foram escolhidos alguns afloramentos, principalmente em cortes de estradas, em locais próximos da área de estudo, permitindo assim a obtenção de um maior número de fraturas para análise estatística. Durante os levantamentos de campo foram também definidas as atitudes de elementos como eixos e planos axiais de dobras.

A principal deformação observada no campo nas litologias do Grupo Paranoá corresponde a dobras com estilo predominante em chevron, geralmente assimétricas, com flancos abertos até apertados, de escala centimétrica a decamétrica. Os eixos medidos apresentam direção geral em torno de N40W e mergulho médio de $15^{\circ}$, com duplo caimento 
para SE e subordinadamente, para NW. O plano axial destas dobras apresenta valor médio de $\mathrm{N} 55 \mathrm{~W} / 80 \mathrm{SW}$. Os valores elevados de inclinação do plano axial dificultam muitas vezes a visualização em campo da vergência das dobras e evidenciam o empinamento do acamamento sedimentar e da foliação.

Em função da sua geometria, estas dobras são correlacionáveis às fases de deformação $F_{2}$ e $F_{3}$, descritas por Freitas-Silva \& Campo (1998). Neste estudo não foi possivel separar as dobras $D_{2}$ e $D_{3}$, ○ que foi observado também por Freitas-Silva \& Campo (1998), que reconhecem as suas semelhanças em estilo e orientação, sendo a separação possivel em afloramentos com áreas restritas.

Com a progressão da deformação, ao final da fase $F_{3}$ foi gerado o sinclinal de Sobradinho. Todo o trecho superior do vale do ribeirão Sobradinho se desenvolveu em um sinclinal assimétrico com eixo de direção aproximada N-NW. Foi nesta fase também que ocorreu a colocação do Sistema de Cavalgamento São Bartolomeu/Paranoá (Freitas-Silva \& Campo 1998), responsável pelo cavalgamento do Grupo Canastra sobre o Grupo Paranoá, observado na região sul da área de estudo.

Foram descritos apenas três afloramentos de filitos do Grupo Canastra na área de estudo nos quais foi possivel identificar apenas dobramentos suaves de escala métrica sem clivagem associada. Estes arqueamentos suaves, de escala desde microscópica até megascópica, representam dobras tardias da fase $D_{3}$ (Freitas-Silva \& Campo 1998).

Não foram reconhecidas, nos afloramentos observados, dobras posteriores àquelas correlacionadas às fases $F_{2}$ e $F_{3}$, possivelmente devido à dificuldade de se encontrar boas exposições de rocha na área estudada. Entretanto, a presença de dobramentos posteriores pode ser inferida a partir da presença da estrutura dômica de Sobradinho, que ocorre na parte nordeste da área estudada. A sua estruturação em domo pode ser reconhecida através de fotografias aéreas, em que se observa um padrão tipicamente radial de drenagem. $O$ padrão de domos e bacias observado no $D F$ é resultado da interferência entre as dobras $D_{2} / D_{3}$ e as dobras $D_{4}$ (Freitas-Silva \& Campo 1998).

Possivelmente após a mega-estruturação da área de estudo, com a formação do sinclinal e o domo de Sobradinho, e do empurrão que colocou as rochas do Grupo Canastra sobre as do Grupo Paranoá, a deformação progrediu para um regime rúptil. De acordo com Freitas-Silva \& Campo (1998), a fase F5, que marca o domínio rúptil, produziu sistemas de fraturamento com orientação sistemática coerente com os indicadores cinemáticos das fases anteriores. Desta forma, o padrão de fraturamento observado no DF corresponde a estruturas de acomodação 
como resultado da liberação do stress residual (deformação elástica) acumulada nas fases anteriores de deformação.

$\mathrm{Na}$ área de estudo foi caracterizada a presença de 4 grandes famílias de fraturas com direções N5W, N30E, N54W e N53E, e cuja gênese foi relacionada às fases $F_{2}$ e $F_{3}$, que representam a principal deformação observada nas litologias da área (figura 15).

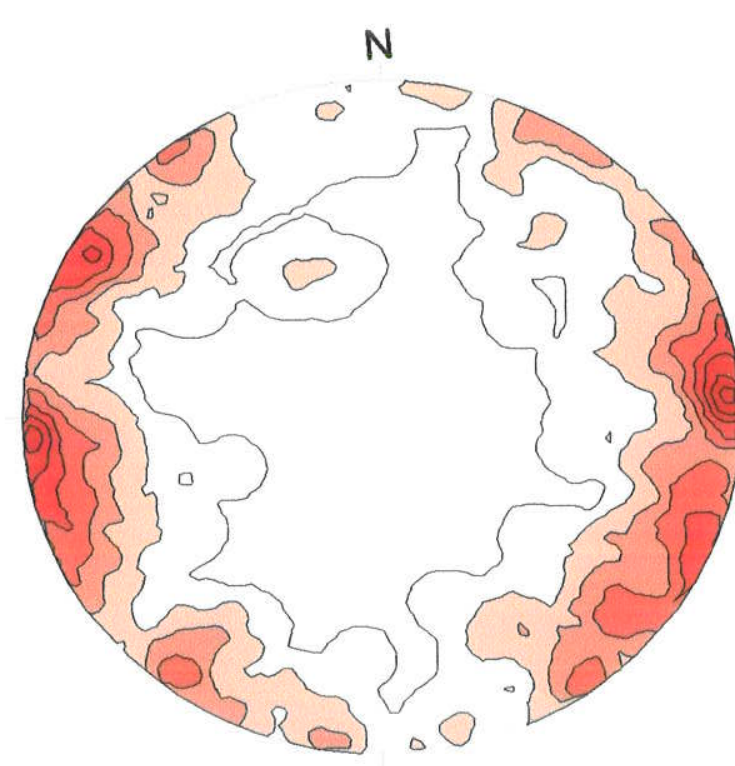

Figura 15. Estereograma equiárea (Schmidt - concentração por 1\% de área ) sinóptico de pólos das fratures. das famílias N54W e N53E (isolinhas a cada 1,08\%; número de fraturas=371).

Predominam amplamente na região as fraturas subverticais $\left(80\right.$ a $\left.90^{\circ}\right)$, com um total de $51,3 \%$, e as de alto mergulho com $40,6 \%\left(60\right.$ a $\left.80^{\circ}\right)$. As fraturas com mergulhos inferiores a $60^{\circ}$ perfazem apenas $8,1 \%$.

Para as fases dúcteis-rúpteis $F_{2}$ e $F_{3}$ foi definido um campo de stress onde os tensores máximo $\left(\sigma_{1}\right)$ e mínimo $\left(\sigma_{3}\right)$ estavam orientados segundo N75-90W, respectivamente com mergulhos para leste e oeste (Campos \& Freitas-Silva 1998). Na área de estudo as famílias de fraturas N5W e N30E correspondem, em geral, a fraturas de extensão, e as famílias N54W e N53E a fraturas de cisalhamento.

As famílias N5W e N30E são dominadas essencialmente por faturas de alto ângulo a subverticais. A família N5W não exibe sentido preferencial de mergulho, enquanto que na família N30E o predomínio é para SE. Os planos destas fraturas estão freqüentemente preenchidos por quartzo maciço, indicando sua natureza extensional. Estas famílias apesar de serem estatisticamente bem representativas são pouco expressivas em termos de traços de drenagem associados. 
As familias de fraturas com direção N54W e N53E, embora dominadas por ângulos altos de mergulhos, apresentam valores relativamente inferiores às outras 2 familias. A família N54W é a única com mergulho bem definido, para $S W$. São fraturas de cisalhamento que formam um par conjugado e são bem expressivas em lineamentos fotointerpretados. A família N53E está bem representada na área pelos lineamentos definidos pelos córregos Capão Grande e Capão Comprido. A familia N54W é bem definida pelo ribeirão Sobradinho (figura 14).

De acordo com Campos \& Freitas-Silva (1998) durante a fase $F_{4}$ o tensor intermediário de stress $\left(\sigma_{2}\right)$ entrou no campo de encurtamento e a deformação progrediu para um regime de extensão (fase $F_{5}$ ) ocorrendo a rotação, em torno do eixo $\left(\sigma_{2}\right)$ que se tornou um eixo extensional, dos tensores de stress máximo $\left(\sigma_{1}\right)$ para a posição subvertical e mínimo $\left(\sigma_{3}\right)$ para a posição subhorizontal, sendo então gerados os sistemas de fraturas extensionais com direções próximas de N-S. Durante a progressão final da deformação, o tensor de deformação intermediário entra no campo extensional, resultando nos sistemas de alivio e dilatação com direções próximas de EW.

$\mathrm{Na}$ área de estudo as fraturas geradas nas fases mais tardias de deformação $\left(F_{4}\right.$ e $\left.F_{5}\right)$ são estatisticamente pouco representativas. No valor de máximo estatístico de direção aproximada N5W (figura 15), não é possivel separar a família com direção N-S. Entretanto, em alguns afloramentos foi possivel separar a familia N30E, gerada durante as fases $F_{2}$ e $F_{3}$, daquela com direção aproximadamente $\mathrm{N}$-S. Esta última aparece cortando veios de quartzo associados à primeira família, indicando seu caráter tardio, possivelmente associado a um regime de deformação rúptil. A família aproximadamente E-W é pouco expressiva, sendo representada na área de estudo por fraturas com mergulhos subverticais e direção N75-85W. Porém ela aparece bem definida como lineamento no trecho superior do ribeirão Sobradinho, próximo à sua nascente, e na região de confluência com o rio São Bartolomeu (figura 14).

Com a mudança na orientação dos tensores de deformação durante a fase $F_{5}$ praticamente todos os sistemas de fraturas pré-existentes foram mais ou menos retrabalhados em regime de extensão, dilatação e alívio (Campos \& Freitas-Silva 1998). Não foi possivel identificar na área de estudo evidências de reativações tectônicas posteriores àquelas relacionadas ao Ciclo Brasiliano (650 Ma), embora existam em alguns locais do Distrito Federal evidências de que a região foi afetada pela tectônica pós-proterozóica, que resultou no modelado do relevo e no desenvolvimento de falhamentos normais que afetam o manto de intemperismo. Embora a mega-estruturação observada na paisagem da área de estudo esteja condicionada às estrutura de idade proterozóica, é possivel que eventos tectônicos posteriores tenham reativado os grandes sistemas de fraturamento identificados na área. 


\subsection{Avaliação do Aqüífero Fraturado}

\subsubsection{Profundidade das entradas de ÁGUA}

Os perfis técnicos dos poços cadastrados revelam que entre as empresas não existe a preocupação de indicar as principais entradas de água (EA) no poço, o que foi observado mesmo naquelas que apresentavam dados mais completos quanto a perfis litológicos $\mathrm{e}$ construtivos. Por isso, em apenas 29 poços haviam informações confiáveis.

As informações quanto a EA nos subsistemas metarritmitos argiloso e arenoso não podem ser consideradas conclusivas em função do pequeno número de poços avaliados. Entretanto, algumas observações podem ser feitas.

A profundidade na qual se iniciam as EA são relativamente profundas, a partir dos $40 \mathrm{~m}$, já que nestes subsistemas o manto de intemperismo é bastante espesso, obrigando o revestimento de uma significativa parte da porção superior do poço. Foi observado que os niveis com fraturamento mais expressivos e no qual ocorrem as fraturas mais produtoras de água, estão associados às camadas ou lentes de quartzitos. Esta característica pode ser estendida a todos os demais subsistemas aqüiferos, sendo a presença de EA associadas a metassiltitos e metargilitos menos expressiva e importante. Por isso, por exemplo, no subsistema Metarritmito Argiloso são detectadas EA desde 41 até $200 \mathrm{~m}$ de profundidade, já que os quartzitos ocorrem nas mais diversas posições estratigráficas dentro do conjunto predominantemente argiloso (figura 16). Nos subsistemas Quartzito e Psamo-Pelito Carbonatado fica evidente que as maiores concentrações de EA, correspondendo a mais de $85 \%$, ocorrem entre 21 e $100 \mathrm{~m}$ (figura 16). É possivel ainda definir que até $80 \mathrm{~m}$ ocorrem as principais zonas de EA, mostrando importante contribuição da zona de alteração da rocha.

As descrições quanto às $E A$ nos poços em geral se apresentaram como classificações de pouco a muito fraturado, abrangendo intervalos de profundidade sem indicações precisas do número de fraturas. Estes dados impossibilitaram o estabelecimento de relações entre número de EA com parâmetros como vazão e vazão especifica. Entretanto, é possivel observar principalmente nos subsistemas que os poços com vazões acima da média tendem a apresentar séries de pequenas entradas de água ao longo do trecho, sugerindo a importância da densidade e intercomunicação entre fraturas. 

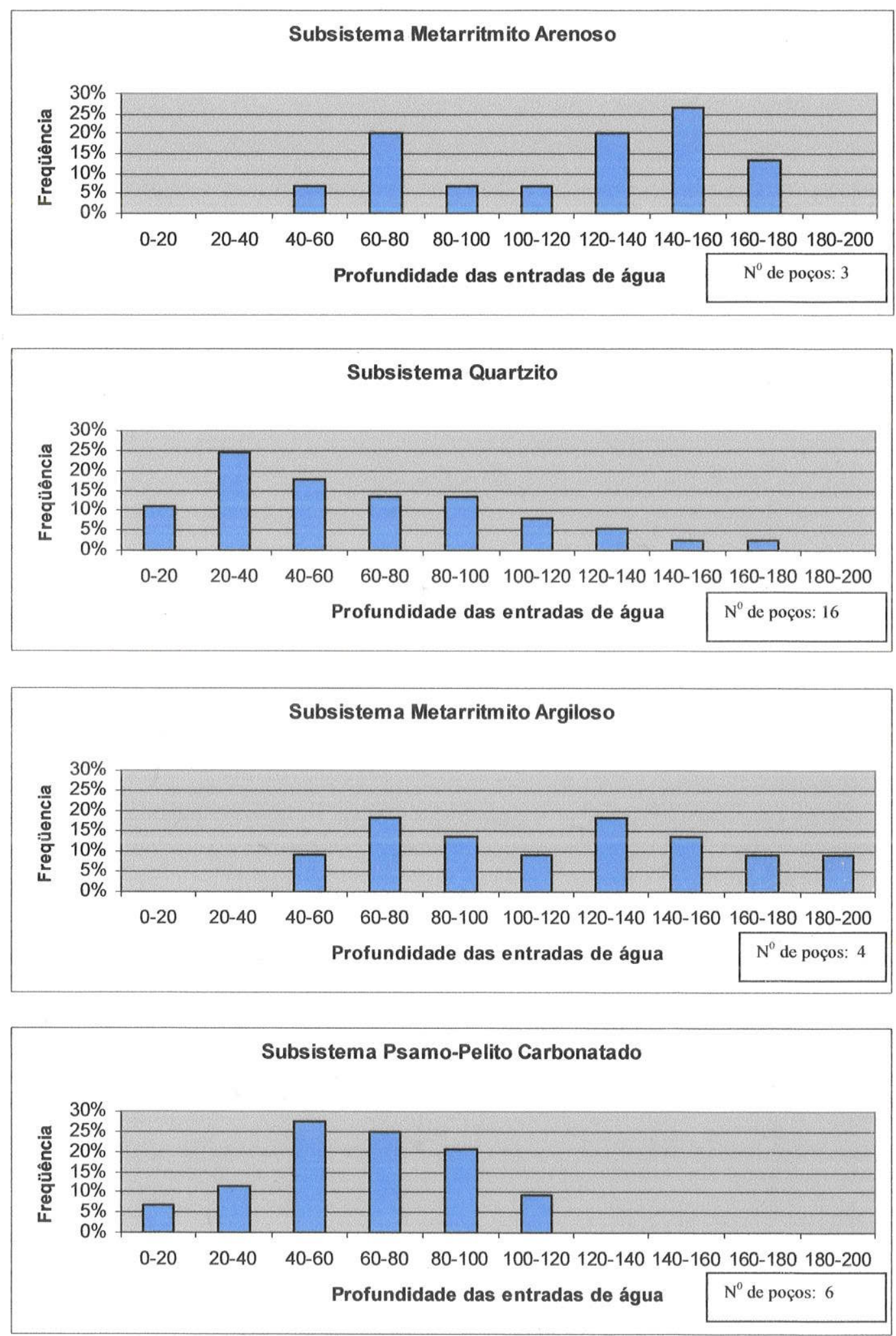

Figura 16. Profundidade das entradas de água nos subsistemas aqüíferos estudados. 


\subsubsection{RELAÇÃO PRODUTIVIDADE DOS POÇOS E LINEAMENTOS}

Em função das significativas variações de vazão e vazão específica entre os subsistemas aqüiferos estudados, a análise da relação produtividade dos poços e lineamentos foi realizada separadamente para cada subsistema. Deste modo, buscou-se avaliar a influência do lineamento para um mesmo tipo litológico. Foi escolhida para esta avaliação a vazão especifica, que vem sendo utilizado como parâmetro indicativo da produtividade de poços em aqüíferos fraturados (Bertachini 1987, Fernandes 1997, Yin \& Brook 1992, Knopman \& Hollyday 1993).

O termo vazão específica, que é expresso através da relação vazão explorada/rebaixamento provocado, foi originalmente introduzido para expressar a capacidade de produção dos poços em aqüíferos porosos. Para o meio fraturado este parâmetro apresenta para o seu uso algumas restrições em função da grande heterogeneidade do meio e dos efeitos de penetração parcial no aqüifero. Além disso, a relação vazão/rebaixamento se comporta de forma diferenciada acima e abaixo das zonas de entrada de água (Menegasse 1991). Durante o teste de vazão o aumento da vazão específica só responde diretamente ao aumento do rebaixamento até a altura da principal entrada de água.

Apesar das imprecisões introduzidas na utilização do termo para aqüiferos fraturados, a vazão específica tem sido bastante utilizada como indicadora mais segura do potencial de produção de um poço quando comparado à vazão. Além disso, a vazão específica em aqüíferos fraturados é controlada principalmente pela abertura total das fraturas atravessadas pelo poço, de modo que a litologia vai exercer papel indireto, no sentido de que suas propriedades reológicas exercem influência sobre a geometria e densidade do fraturamento (Fernandes 1997).

Não foi possivel relacionar a produtividade dos poços aos lineamentos fotointerpretados na área de estudo (figura 17), apesar de terem sido caracterizadas, através da análise do fraturamento, as fraturas abertas. Alguns aspectos podem ter contribuído para este resultado. 0 manto de intemperismo, associado a um relevo plano a suavemente ondulado, mascara algumas fraturas em subsuperfície. Além disso, os poços utilizados no estudo não apresentam distribuição homogênea ao longo da região, concentrando-se na porção norte da área de estudo. Desta forma a análise ficou praticamente restrita àquela área. 


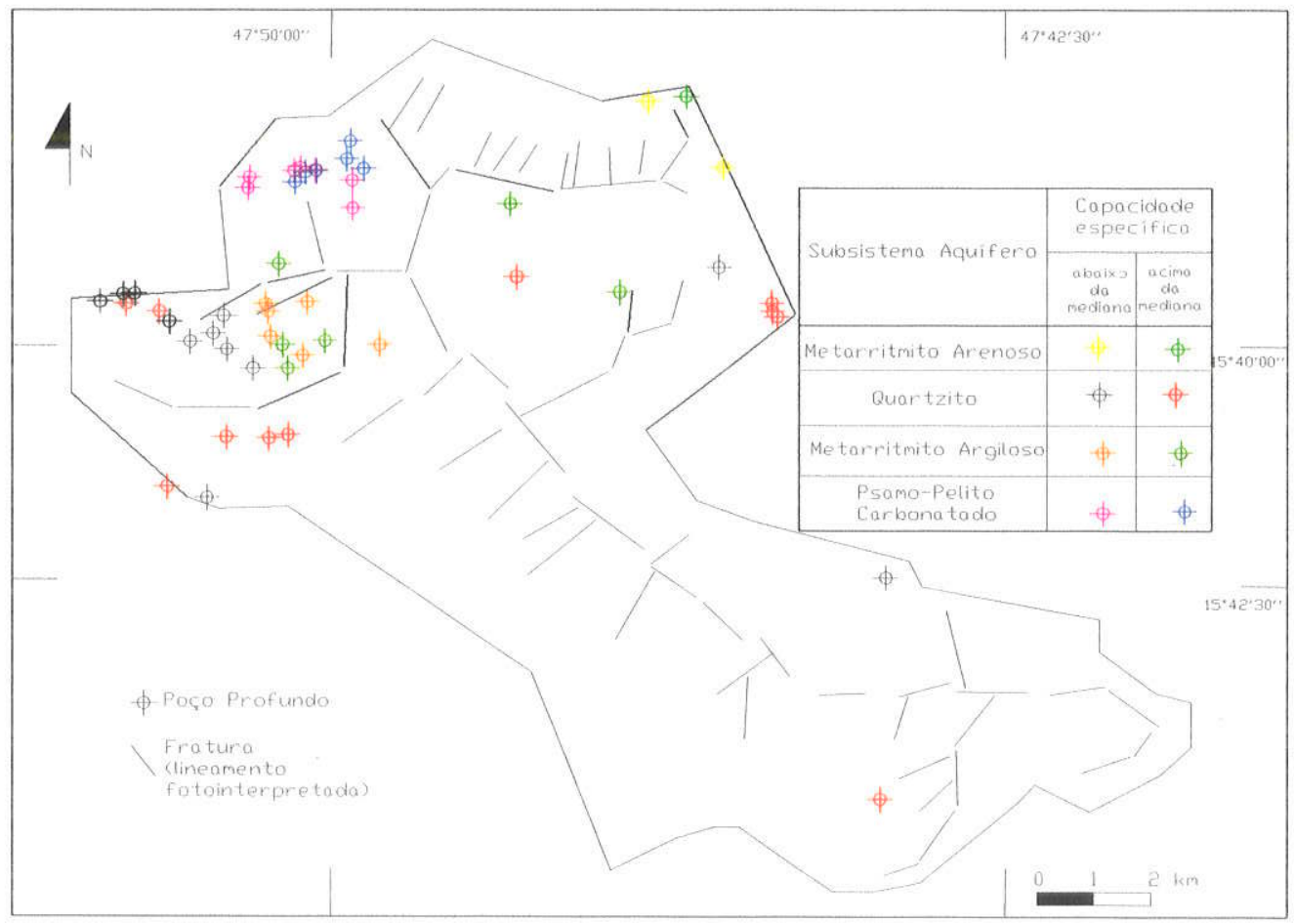

Figura 17. Mapa relacionando lineamentos e vazão específica dos poços nos diferentes subsistemas aqüíferos.

\subsubsection{CRITÉRIOS PARA LOCAÇÃO DE POÇOS}

Os aqüíferos fraturados na área estudada apresentam forte controle litológico, em função das diferenças de comportamento reológico das litologias durante a deformação rúptil. As variações de competência entre as rochas refletem diretamente no padrão de fraturamento.

Os quartzitos são as litologias mais competentes e apresentam comportamento rúptil, produzindo uma razoável densidade de fraturas abertas, que pode ser observada em afloramentos. Os metassiltitos e metargilitos apresentam comportamento mais plástico e dúctil que os quartzitos. Apesar de terem sido submetidos às mesmas condições de metamorfismo e deformação, em função da sua maior plasticidade, apresentam menor densidade de fraturas e os planos de fraturamento tendem a serem mais fechados. Os filitos do Grupo Canastra apresentam alta plasticidade e baixa permeabilidade, que é evidenciada pela alta densidade de drenagem em fotos aéreas e manto de intemperismo delgado e argiloso. Por isso, também apresentam condições pouco favoráveis para a transmissão e o armazenamento de água.

O critério geomorfológico, utilizado em alguns estudos como indicador da produtividade dos poços pode ser aplicado à área estudada, sendo diretamente correlacionável ao fator 
litologia. Isto porque as unidades com predominio da fração psamítica, principalmente quartzitos, correspondem aos subsistemas aqüiferos Quartzito e Metarritmito Arenoso, que ocorrem nas áreas mais elevadas da região e apresentam poços com boas vazões. Na região de vale podem ser obtidas elevadas produtividade dos poços apenas onde são atingidas expressivas camadas ou lentes de quartzitos do subsistema aqüifero Psamo-Pelito Carbonatado.

Embora não tenha sido possivel relacionar a produtividade dos poços ao tipo de lineamento, em função da gênese do fraturamento, os sistemas de fraturas N5W e N30E, por sua natureza extensional, podem formar bons aqüiferos. Considerando apenas os sistemas de deformação rúpteis, os sistemas de fraturas N-S e N75-85W também são favoráveis. Embora nem sempre seja possível identificar no campo lineamentos associados a estas familias de fraturas, estudos geofísicos poderão auxiliar na sua identificação, fornecendo subsídios para a locação de poços.

\subsection{ASPECTOS DA RECARGA E ESCOAMENTO}

A recarga dos aqüíferos estudados é basicamente função da precipitação pluviométrica e das caracteristicas físicas da bacia (relevo e tipo de solo), que determinam o volume que efetivamente infiltra no subsolo. Os domínios poroso e fraturado apresentam condições próprias de recarga, circulação e descarga, em função das suas características hidrogeológicas intrínsecas. Embora possam ser avaliados separadamente, eles encontram-se hidraulicamente conectados e as relações entre os dois sistemas podem controlar o volume de água que circula no sistema. Além disso, aspectos como o uso e ocupação do solo podem alterar o sistema natural, modificando significativamente os mecanismos de recarga.

\section{- Domínio Poroso}

A principal fonte de recarga das águas do manto de intemperismo é a precipitação pluviométrica. Os dados obtidos através do balanço hídrico indicam que $28 \%$ da precipitação pluviométrica anual infiltra no subsolo, atingindo o aqüifero.

$\mathrm{Na}$ região norte da bacia, ocupada principaimente pelos condomínios, no qual se concentram os usuários de poços profundos, a água retirada do dominio fraturado é importante fonte de alimentação para o domínio poroso. Como nesse locais não existe rede coletora de esgotos, as águas residuárias são infiltradas no solo através de fossas sépticas ou negras. 
Desta forma, a água do meio fraturado é restituida ao manto poroso. Subordinadamente, a irrigação em algumas chácaras do Núcleo Rural de Sobradinho 1, que emprega água de córregos, contribui como fonte de alimentação do aqüífero.

O relevo plano a suavemente ondulado na região mais alta das chapadas $e$ as declividades baixas, inferiores a $8 \%$ nas encostas, favorecem significativamente as condições de infiltração na área estudada. Como as porções topograficamente mais elevadas correspondem a áreas no qual o manto de intemperismo tem grande contribuição da alteração de quartzitos (unidades $R_{3}$ e $Q_{3}$ ), as características de elevada permeabilidade e relevo favorecem a infiltração nas zonas de recarga. A existência de extensa área de reflorestamento na porção oeste da bacia recoberta por pinheiros e o baixo nivel de ocupação humana favorecem as condições de recarga do aqüifero.

As condições de recarga não são favoráveis na região do vale dissecado do São Bartolomeu, no qual um relevo com declividades mais acentuadas (chegam a ser maiores que $20 \%$ ) associadas a um manto de intemperismo raso e pouco permeável, são pouco favoráveis à infiltração.

Um aspecto importante a ser destacado é que atualmente existe uma elevada taxa de ocupação na região norte da bacia, principalmente nas regiões topograficamente mais elevadas. O nivel de ocupação destas áreas tem aumentado nos últimos anos resultando na formação de aglomerados urbanos, que estão se consolidando cada vez mais através da pavimentação de ruas e construções, com redução da área verde, produzindo significativa impermeabilização de amplas áreas do terreno. Por isso, é possivel diagnosticar um aumento do escoamento superficial nestas regiões e redução da infiltração. A redução da taxa de recarga do aqüifero nestes locais pode ser considerada preocupante, em função do elevado consumo de água subterrânea através de poços profundos nos condomínios.

O principal exutório do domínio poroso na área é o ribeirão Sobradinho e, secundariamente, os córregos Paranoazinho, Capão Grande e Capão Comprido. A manutenção do fluxo superficial dos córregos e ribeirões da região se deve à restituição do aqüifero do manto de intemperismo, respondendo pela perenidade destas drenagens. As condições de fluxo laminar para as menores cotas topográficas, principalmente os vales da região, são controladas pelas variações de condutividade hidráulica dentro do manto de intemperismo, a topografia do substrato rochoso e o contraste de permeabilidade entre o manto e as rochas.

As fontes observadas na área de estudo são de contato e ocorrem nos locais de quebra de relevo, na transição entre as chapadas, de superficie plana, e a região de encosta com declividades mais elevadas. Nestes locais o nível freático bastante raso, com cerca de $4 \mathrm{~m}$ de 
profundidade, aflora quando a superfície de erosão atinge o contato entre o manto de intemperismo com o embasamento, meios de permeabilidades diferentes. São portanto, fontes relacionadas a fluxos locais e na grande maioria intermitentes, sendo aproveitadas por algumas chácaras e condomínios localizados, principalmente, na região norte da bacia. Estas fontes são responsáveis pela formação de pequenos cursos de água que chegam ao ribeirão Sobradinho (figura 18).

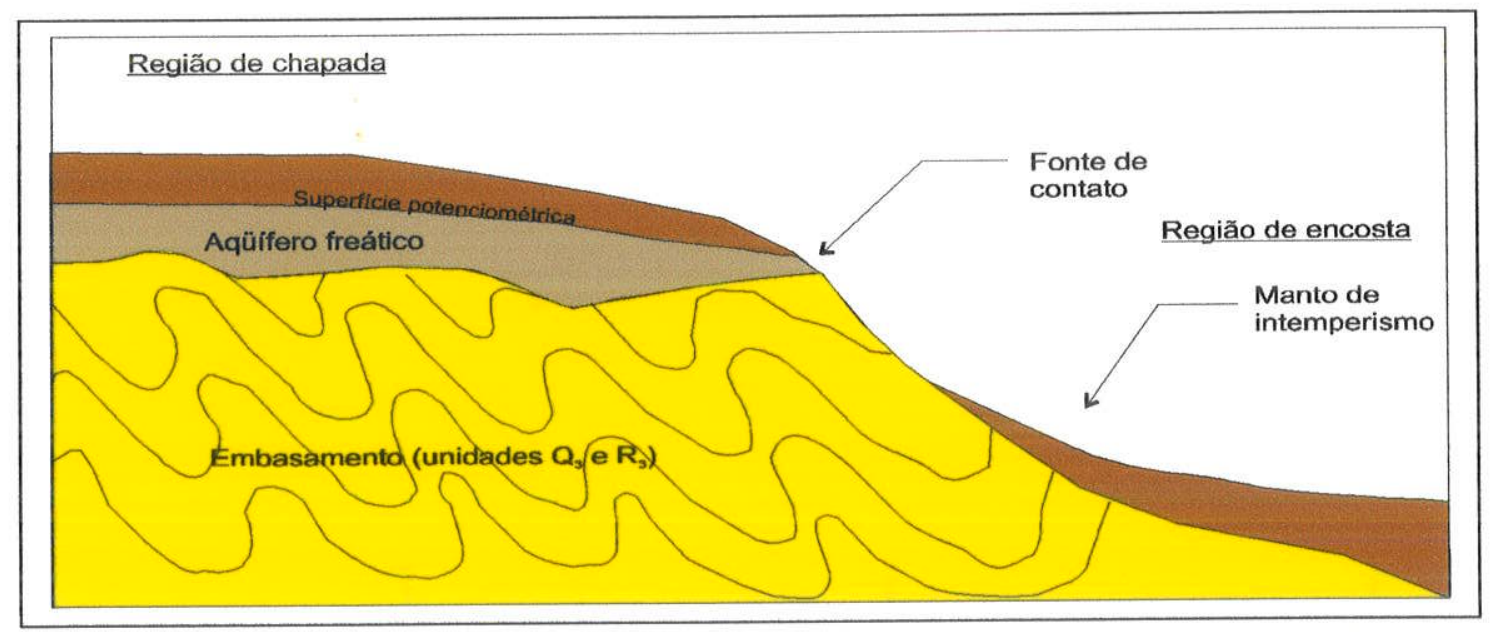

Figura 18. Principal tipo de fonte observada na área de estudo e importante exutório do manto de intemperismo. A surgência normalmente ocorre de forma difusa, onde o contato entre embasamento e manto de intemperismo aflora na superfície.

O último importante exutório do domínio poroso é representado pelo sistema fraturado subjacente. Neste caso o movimento descendente e subordinadamente, lateral da água, garante a alimentação das descontinuidades físicas do meio rochoso, representadas principalmente pelas fraturas.

\section{- Domínio Fraturado}

Em função do extenso manto de intemperismo que recobre a área, é possível afirmar que a alimentação do domínio fraturado diretamente por águas meteóricas deve ser muito restrita a inexistente. Por isso, o manto exerce papel fundamental sobre as condições de recarga das fraturas em subsuperfície, em função de fatores como espessura e permeabilidade. Além disso, no domínio fraturado ocorrem sistemas de fraturas com extensões restritas, na qual o manto sotoposto é responsável diretamente pela alimentação das fraturas, sendo muitas vezes mais importante do que a recarga em regiões topograficamente mais elevadas.

A avaliação das reservas hídricas para os domínios poroso e fraturado na região estudada é muito difícil. Embora tenha sido possível estimar a parte de água de precipitação 
que infiltra e atinge o aqüifero poroso, o nivel de conhecimento atual não permite definir o volume que efetivamente participa da recarga do aqüifero fraturado, impedindo o estabelecimento das reservas de água subterrânea.

Em áreas de ocorrência dos subsistemas aqüiferos Metarritmito Arenoso e Quartzito, nos quais solo e saprolito têm caráter predominantemente arenoso e os processos de laterização são, em geral, incipientes, existem condições favoráveis para a recarga das fraturas. Por outro lado, nos subsistemas Metarritmito Argiloso e Psamo-Pelito Carbonatado, apesar da grande espessura do manto de intemperismo associado e da boa permeabilidade dos solos, as características hidráulicas dos saprolitos possivelmente exercem importante papel sobre a taxa de recarga do aqüifero subjacente, porque é nestes locais que ocorre o contato manto/fraturas. Naqueles locais onde o processo de laterização está avançado e a rocha mãe corresponde a metargilito e metassiltito as condições de recarga não são favoráveis.

Campos \& Freitas-Silva (1998) consideram que a atitude da foliação principal, ou dos planos de acamamento, também desempenha um papel importante no controle da recarga dos sistemas fissurais. Quanto maior o ângulo da estrutura planar (principalmente foliação) maior será a vazão de infiltração para alimentação das zonas fraturadas. Neste caso há a soma da porosidade secundária em função do fraturamento e a porosidade secundária em função da alteração intempérica na zona de saprolitos.

$\mathrm{Na}$ área de ocorrência dos filitos do Grupo Canastra onde ocorrem solos delgados e relevo mais acidentado, a recarga através do manto de intemperismo, é muito pequena.

$\mathrm{Na}$ área de estudo não foi possível estabelecer com precisão os exutórios do domínio fraturado. Possivelmente o principal exutório é representado pela rede de drenagem. 


\section{Avaliação das Obras de Captação}

Foi realizado um inventário sistemático das características técnicas construtivas e de uso e conservação das obras de captação de água subterrânea. Essa análise visou compreender as condições de explotação e proteção dos aqüiferos, fornecendo subsidios para uma planificação do uso e preservação do recurso hídrico subterrâneo na região estudada. A figura 19 mostra a localização das obras de captação de água subterrânea cadastradas na área.

Foram identificados, na área de estudo, dois tipos de obras de captação de água subterrânea: os poços tubulares ou profundos, e os poços rasos. O poço tubular como obra de engenharia deve ser regulamentada junto ao CREA (Conselho Regional de Engenharia e Arquitetura) e para sua construção devem ser seguidas as normas NBR-588/1990 e NBR1290/1990 da ABNT (Associação Brasileira de Normas Técnicas). Em relação aos poços rasos não existem normas técnicas para a sua construção, mas manuais e relatórios que apresentam características básicas importantes a serem adotadas. A avaliação das obras de captação buscou relacionar os aspectos descritos nas fichas técnicas dos poços e aqueles observados no campo com as normas técnicas existentes.

\subsection{Poços PROFUndos}

Foram cadastrados 97 poços tubulares profundos na região estudada, dos quais em 91 existia ficha técnica do poço. Foram incluídos no banco de dados 6 poços sem informações técnicas, que em função das suas condições de precárias de desativação ou abandono serão analisados separadamente.

A etapa de campo revelou a existência de poços profundos para os quais não havia registro no pré-levantamento realizado junto às maiores empresas de perfuração. Em alguns casos, os proprietários forneceram a ficha técnica ou algumas informações, de forma que estes poços puderam ser incluídos no cadastro de poços tubulares. Entretanto, na maior parte destes casos observou-se a ausência de informações do proprietário sobre o poço.

Estes poços sem dados confiáveis encontram-se apenas indicados no banco de dados, estão localizados principalmente nos condomínios, nos quais as mudanças de administração periódicas terminam gerando a perda da ficha técnica. Em outros casos a ausência de informações se deve essencialmente à deficiência técnica dos dados das empresas executoras dos poços. 


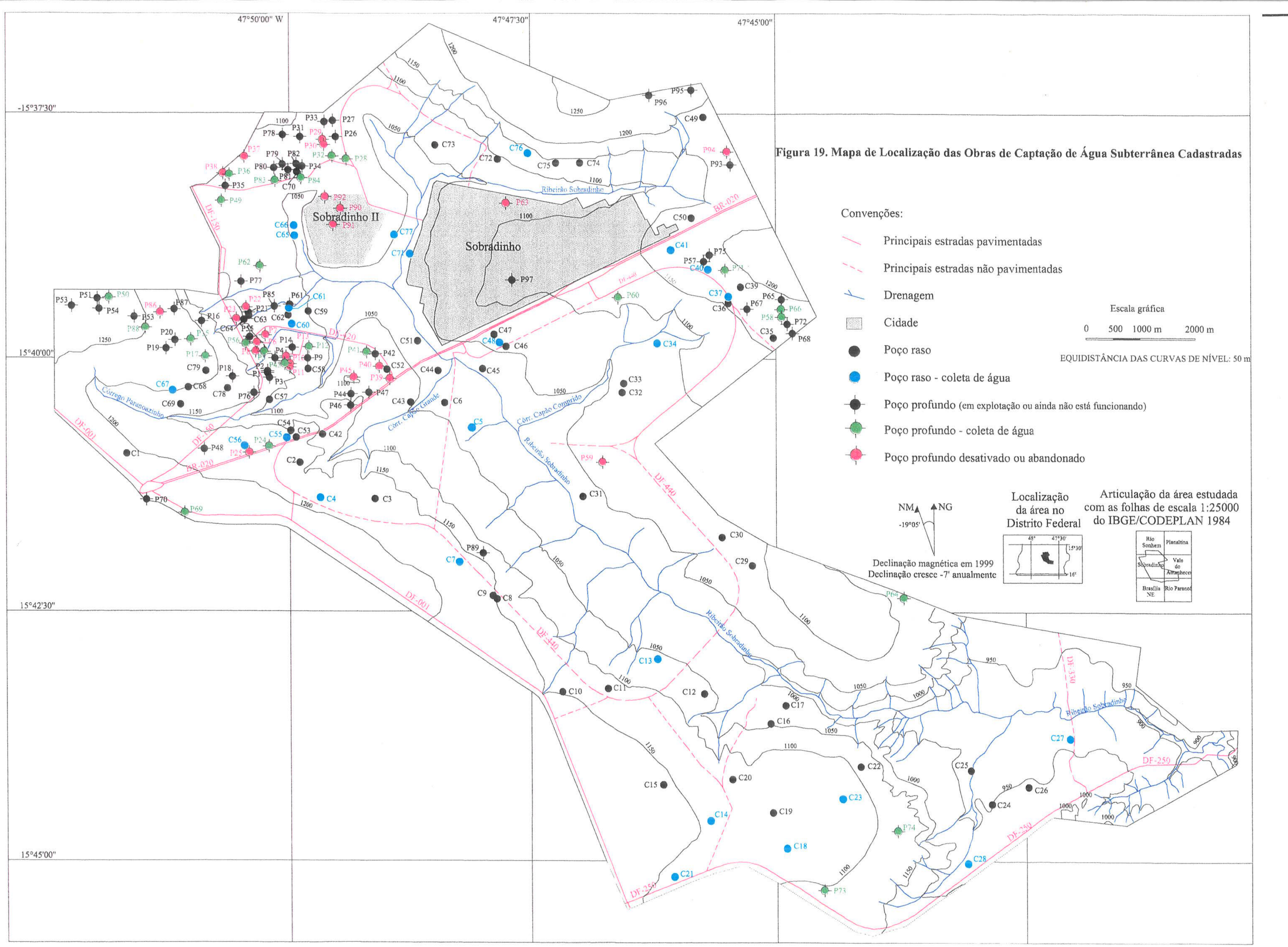


Durante os levantamentos de campo, foi observada a atuação na área de estudo de perfuradores autônomos que desconhecem os conceitos mais básicos de hidrogeologia. Além disso, empregam equipamentos de perfuração bastante antigos e possivelmente utilizam na obra materiais de baixa qualidade. São obras que, quando concluídas, não apresentam fichas técnicas, o que se justifica em função do baixo nivel técnico do executante. Como não é objetivo deste estudo cadastrar as obras de captação na área, estes poços não foram incluídos no banco de dados.

\subsubsection{HISTÓRICO DAS PERFURAÇÕES}

O inventário dos poços tubulares na área de estudo indica a atuação de 15 empresas na perfuração de poços (tabela 10). As empresas Colorado e Hidropoços apresentaram um maior número de poços construídos, como mostra a tabela 10.

Tabela 10. Empresas de perfuração de poços que atuaram na área de estudo.

\begin{tabular}{|c|c|}
\hline Empresa & Número de Poços \\
\hline Aguatec Comércio e Representação Ltda. & 1 \\
\hline Aquapura Poços Artesianos Ltda. & 1 \\
\hline Colono Ltda. & 54 \\
\hline Colorado Perfuração de Poços Artesianos Ltda. & 1 \\
\hline Constroll Projeto e Construção Ltda. & 2 \\
\hline Fluxor Poços Artesianos Ltda. & 3 \\
\hline Geodril Poços Artesianos Ltda. & 1 \\
\hline Geo-Sonda Eletro-Hidráulica Ltda. & 2 \\
\hline Global Bombas e Poços Ltda. & 1 \\
\hline Hidra & 1 \\
\hline Hidroingá Poços Artesianos Ltda. & 1 \\
\hline Hidrorizonte Ltda. & 13 \\
\hline Hidropoços Ltda. & 5 \\
\hline Hidropoços Brasil Ltda. & 3 \\
\hline Netuno Poços Artesianos Ltda. & Total - 91 \\
\hline
\end{tabular}

Das empresas construtoras consultadas, apenas a Colorado apresentou relatório detalhado com as características técnicas da obra. Os relatórios da Hidropoços, Hidrorizonte, Aquapura e Netuno foram considerados satisfatórios. Nas demais, foi observada a deficiência quanto à constância na apresentação dos dados. Com relação à apresentação de seção colunar com descrição litológica apenas a Colorado, Hidropoços e Hidrorizonte apresentaram perfis geológicos de boa qualidade. 
Com base nos dados levantados, foi possível elaborar um gráfico com a tendência anual de construção dos poços a partir do ano de 1988 (figura 20). O crescimento populacional na bacia é principalmente função do processo de desmembramento de propriedades particulares, com a formação de lotes e condomínios, e as invasões em áreas públicas. Desta forma, surgiu uma grande demanda por água, iniciando o aproveitamento progressivo das águas subterrâneas.

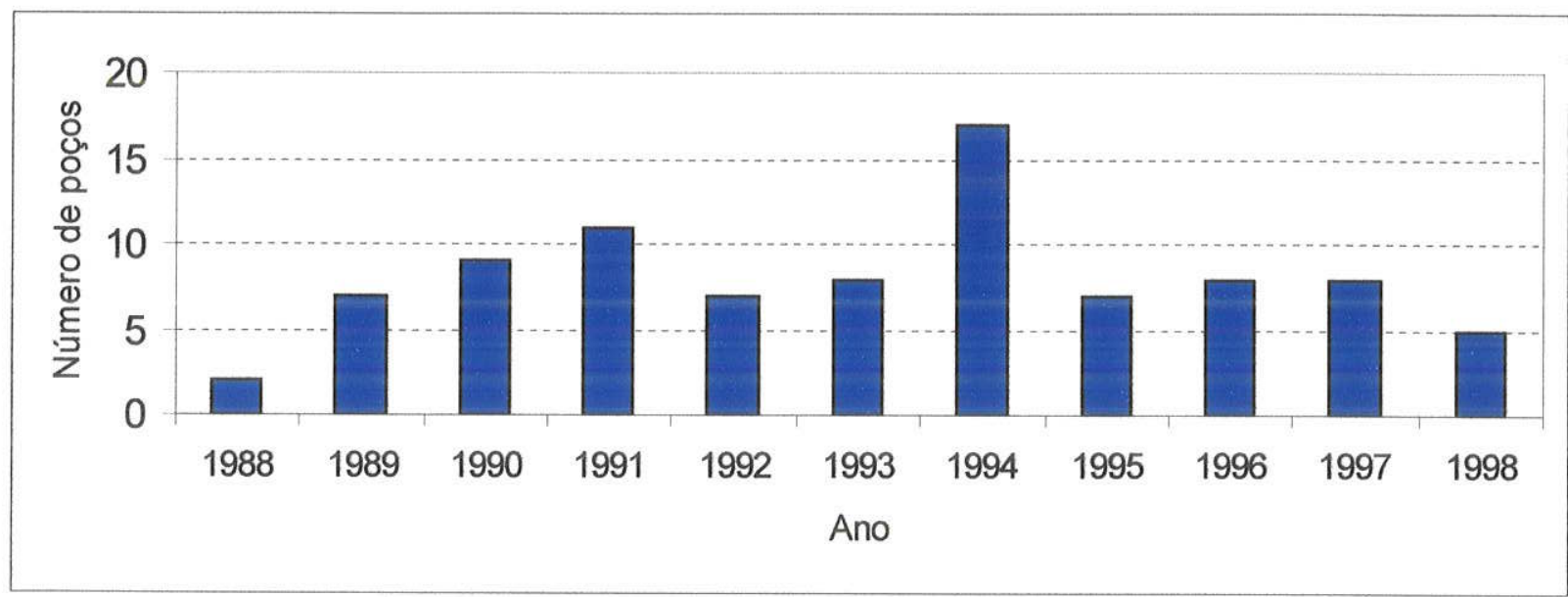

Figura 20. Evolução do número de poços perfurados na área de estudo entre 1988 e 1998 (dois poços cadastrados não possuíam informações quanto ao ano da perfuração).

Os anos de 1990 e 1991 apresentam um aumento da demanda pela água subterrânea e corresponde ao início do processo de formação principalmente dos condomínios. O outro pico de demanda se deu em 1994, período em que ocorreu a consolidação destes condomínios. É interessante ressaltar que desde 1989 o crescimento do número de poços tubulares apresenta uma grande regularidade, com uma média anual de 7 poços.

Em função do início do processo de regularização das invasões e condomínios junto ao Governo do Distrito Federal (GDF) a partir de 1997, e das melhorias que foram observadas na infra-estrutura (asfaltamento e rede de água), nos condomínios mais antigos, a expectativa é que a demanda pela água subterrânea possa se intensificar nos próximos anos. Atualmente está ocorrendo um aumento no nível de ocupação dos lotes nos condomínios que, de acordo com os dados obtidos no campo, está em torno de $60 \%$ e se deve principalmente às melhorias de infra-estrutura nestes locais.

\subsubsection{ESTADO ATUAL DOS POÇOS}

A fim de caracterizar a situação atual dos poços os mesmos foram classificados como:

- em explotação;

- desativados (poços que foram explotados durante um certo período); 
- abandonados (poços que nunca foram explotados, em geral, devido às baixas vazões);

- ainda não explotados (poços recém-perfurados que ainda não estavam em operação).

De acordo com os dados levantados, os poços foram classificados como mostra a tabela 11.

Tabela 11. Situação atual dos poços.

\begin{tabular}{|c|c|c|}
\hline Situação Atual & Número de Poços & $\%$ \\
\hline Em explotação & 68 & 74.7 \\
\hline Desativados & 10 & 11.0 \\
\hline Abandonados & 7 & 7.7 \\
\hline Ainda não explotados & 6 & 6.6 \\
\hline & Total -91 & 100 \\
\hline
\end{tabular}

E possivel pela figura 19 observar que existe uma distribuição extremamente irregular dos poços na área, com cerca de $95 \%$ se concentrando na parte norte da bacia, correspondendo à zona de ocupação com característica urbana, onde está a maioria das invasões e condomínios. A sul desta área a ocupação é de caráter principalmente rural, predominando a utilização de poços rasos.

\subsubsection{LOCAÇÃO}

O aspecto mais comum na locação dos poços na região é a ausência de critérios na sua execução, principalmente porque a maioria das empresas não dispõem de geólogo ou responsável com conhecimento técnico. Nos grandes condomínios, apesar do espaço físico, existe um significativo número de poços abandonados ou desativados por queda de vazão. Nas chácaras e condomínios pequenos, devido ao reduzido espaço físico e o custo, a execução de estudos hidrogeológicos prévios à realização da obra é dificultada. Além disso, muitas vezes a localização do poço é imposta pelo solicitante.

Uma prática comum que ilustra este fato, é a proximidade com que estão locados muito poços nestes condomínios. No Condomínio Vivendas Paraíso, por exemplo, um terceiro poço foi locado exatamente entre os dois já existentes, ficando separados entre si por uma distância de cerca de $40 \mathrm{~m}$, produzindo interferência entre os poços e reduzindo significativamente as vazões obtidas.

Em função do baixo custo e da simplicidade de execução, a investigação em subsuperficie tem sido muitas vezes substituida pela radiestesia, que utiliza diversos instrumentos como forquilha de madeira e pêndulo. Embora esta prática não apresente fundamento científico, alguns proprietários de poços e empresas afirmam terem obtido bons resultados. 
De forma mais restrita, a geofísica tem sido empregada, tendo sido reconhecidos na área o emprego de duas metodologias: o magnético-telúrico (poços P52 a P55) e eletromagnético (poços P20, P93 a P96). Embora os resultados não tenham sido sempre satisfatórios, a utilização da geofísica ainda é pouco conhecida dos contratantes de obras e, muitas vezes, aumenta significativamente os custos de execução do poço.

\subsubsection{CARACTERÍsticas tÉCNICAS de CONSTRUÇÃo}

\section{- MÉtodo de perfuração}

$\mathrm{Na}$ perfuração dos poços, foram identificados dois métodos: a percussão (sonda percussora ou de cabo) e o roto-pneumático (combinação dos métodos a percussão e rotativo). Embora o método a percusssão domine amplamente, tendo sido empregado em $92,4 \%$ das perfurações, o seu rendimento em geral não é muito bom, com uma média de 6 a $8 \mathrm{~m} /$ dia. A sua ampla utilização se deve ao fato de que as empresas não dispõem de outro tipo de equipamento. Aliás, se observa que uma parte significativa das perfuratrizes em operação são antigas, apresentando baixos índices de produtividade.

Nos últimos anos, com a atuação de empresas de outros estados no DF, algumas empresas locais vêm tentando melhorar sua competitividade, empregando sondas rotopneumáticas, cujo rendimento médio na área é de 100 a $120 \mathrm{~m} /$ dia. Como esta é uma tendência recente, apenas $7,6 \%$ poços foram perfurados através deste método.

\section{- DiÂmetro}

Após ser iniciada a perfuração de poços, o seu diâmetro pode permanecer ou não constante. A escolha do diâmetro depende de fatores como o grau de resistência das litologias atravessadas, as condições da perfuração e a bomba requerida para o seu funcionamento adequado, influindo significativamente no custo da estrutura do poço (JOHNSON 1966, FCTH 1988).

Os dados levantados indicam que foram utilizados até 4 diâmetros durante a perfuração (tabela 12). Em $28,6 \%$ dos poços esta informação não estava disponível. Predominou a utilização de 2 e 3 diâmetros, que correspondem a $67 \%$ do total de poços. Entre os poços que utilizaram 2 diâmetros foram empregados os seguintes valores: 10" e 6" $(21,4 \%), 10 "$ e $8 "(28,6 \%), 10 "$ e $9 "(21,4 \% \%), 8 "$ e $6 "(28,6 \%)$. Entre aqueles que apresentaram 3 diâmetros de perfuração, só 1 poço foi de $14^{\prime \prime}, 10^{\prime \prime}$ e 6 ", sendo que todos os demais utilizaram 10", 8" e 6". O diâmetro mais freqüentemente utilizado para completar a parte inferior dos poços perfurada na rocha sã foi de 6". 
Tabela 12. Número de diâmetros utilizados na perfuração dos poços.

\begin{tabular}{|c|c|c|}
\hline Número de diâmetros & Número de poços & $\%$ \\
\hline 1 & 2 & 2,2 \\
\hline 2 & 14 & 15,4 \\
\hline 3 & 47 & 51,6 \\
\hline 4 & 3 & 3,3 \\
\hline Sem informação & 25 & 28,6 \\
\hline & Total - 91 & 100 \\
\hline
\end{tabular}

\section{- Profundidade}

A profundidade de um poço é determinada em função de vários fatores, entre os quais os principais são o custo e a vazão desejada. A profundidade média dos poços na área é de $127 \mathrm{~m}$, sendo que os valores mínimo e máximo são respectivamente, de 45 e 230 $\mathrm{m}$. Os resultados indicam que $35,1 \%$ têm até $100 \mathrm{~m}$ de profundidade e $61,6 \%$ têm entre 100 e $199 \mathrm{~m}$ (tabela 13).

Tabela 13. Classes de profundidade dos poços.

\begin{tabular}{|c|c|c|}
\hline Profundidade $(\mathbf{m})$ & Número de poços & $\%$ \\
\hline Até 100 & 32 & 35,1 \\
\hline 100 a 150 & 30 & 33,0 \\
\hline 150 a 200 & 26 & 28,6 \\
\hline Superior a 200 & 3 & 3,3 \\
\hline & Total -91 & 100 \\
\hline
\end{tabular}

A profundidade dos poços na região é determinada basicamente pelos contratos de perfuração, que geralmente tomam como base a profundidade de $100 \mathrm{~m}$. Se a essa profundidade, a vazão obtida pelo poço for considerada satisfatória pelo contratante, a perfuração é encerrada. Caso contrário, a perfuração prossegue até se atingir a vazão desejada ou não haverem indícios da possibilidade de se conseguir esse valor.

\section{- Revestimento}

Os tubos de revestimento têm como objetivo evitar o desmoronamento do furo e a entrada de águas superficiais ou de infiltração rasa no poço, que pode afetar a qualidade da água captada. Além disso, estabelecem a ligação entre a zona de entrada de água no poço com a superfície.

As profundidades revestidas variaram desde 3 até $183 \mathrm{~m}$, em função basicamente da espessura do manto de intemperismo, do fenômeno da colapsividade e do intemperismo químico diferencial. A colapsividade resulta do alto grau de intemperismo de solos e 
saprolitos de regiões tropicais. Em quartzitos, por exemplo, tal fenômeno produz a destruição da cimentação silicosa, transformando-o em saprolito com estrutura friável e elevado índice de vazios. Com a saturação deste material por água, durante a perfuração dos poços o desmoronamento é comum. O mecanismo responsável pelo intemperismo químico diferencial que afeta as litologias da região do DF ainda não é bem entendido. Entretanto, ele é relacionado ao intenso intemperismo observado freqüentemente em niveis pelíticos dentro do pacote de rocha sã, que obriga o revestimento do poço para evitar o desmoronamento das suas paredes.

De acordo com os dados levantados, $83,5 \%$ dos poços foram construídos com 1 revestimento e $4,4 \%$ com 2 revestimentos (tabela 14). Em todos os poços com informações técnicas, o revestimento interno apresentava diâmetro de $6 "$.

Tabela 14. Número de revestimentos utilizados nos poços.

\begin{tabular}{|c|c|c|}
\hline Número de revestimentos & Número de Poços & $\%$ \\
\hline 1 & 76 & 83,5 \\
\hline 2 & 4 & 4,4 \\
\hline $\begin{array}{c}\text { Sem revestimento } \\
\text { (poços abandonados) }\end{array}$ & 4 & 4,4 \\
\hline Sem informações & 7 & 7,7 \\
\hline & Total -91 & 100 \\
\hline
\end{tabular}

Entre os 4 poços com 2 revestimentos, 2 deles apresentaram o revestimento (tubo) externo com 8" de diâmetro. O tubo externo ou de boca é uma tubulação lisa utilizada durante a perfuração dos poços a fim de manter a estabilidade das paredes, evitando assim o desmoronamento. Nos outros 2 poços, foram empregados 2 diferentes tipos de revestimento no mesmo poço e com o mesmo diâmetro.

A avaliação das características técnicas dos poços revelou que 78 poços possuíam informação quanto ao tipo de revestimento interno empregado. Deste total foram utilizados em 38,5\% (30 poços) PVC geomecânico, 5,1\% (4) aço galvanizado, 10,2\% (8) aço da série DIN 2440 e $46,2 \%$ (36) aço-carbono. Nos 2 poços com tubo externo, foi utilizado açocarbono liso.

\section{- FILTRO E PRÉ-FILTRO}

O filtro do poço é colocado em determinada seção do poço e tem a função de captar água do aqüifero, permitindo que ela flua livremente para o poço com perda minima de carga, impedindo a penetração de partículas e funcionando como um suporte estrutural. A escolha do tipo de filtro deve levar em conta as caracteristicas físico-químicas da água, os 
esforços a que ele será submetido e as características granulométricas das amostras obtidas durante a perfuração (JOHNSON 1966). Essa escolha é muito importante pois ela determina em grande parte a vida útil do poço.

A utilização de filtros é bastante comum na área de estudo apesar dos poços explotarem basicamente os aqüiferos fraturados. A colocação dos filtros geralmente ocorre nas principais entradas de água (zonas fraturadas) e está associada ao intemperismo químico diferencial que atua sobre as rochas, obrigando o revestimento de grande parte da seção perfurada. A análise dos perfis técnicos dos poços revelou que em $13,2 \%$ não havia informação quanto a filtros e em $20,9 \%$ não houve instalação (tabela 15).

Todos os filtros utilizados apresentaram diâmetro de 6 " que foi determinado essencialmente em função dos tubos de revestimento interno. Em relação ao tamanho da abertura dos filtros, foram obtidos os seguintes valores: $0,45 \mathrm{~mm}(2,1 \%), 0,5 \mathrm{~mm}(35,4 \%)$, $0,75 \mathrm{~mm}(10,4 \%)$ e $1 \mathrm{~mm}(52,1 \%)$.

A avaliação das características técnicas dos poços revelou que 62 poços possuiam informação quanto ao tipo de material do filtro. Deste total, 43,5\% (27 poços) utilizaram PVC geomecânico, $53,2 \%$ do tipo Nold (33) e 3,3\% de aço da série DIN 2440, sem especificações ( 2 poços). O comprimento dos filtros por seção variou desde 2 até $14 \mathrm{~m}$, sendo que a grande maioria se situou entre 2 e $4 \mathrm{~m}$. O emprego de filtros em trechos normalmente restritos reflete a captação de água nos niveis fraturados.

Tabela 15. Informações técnicas disponiveis sobre os filtros dos poços.

\begin{tabular}{|c|c|c|c|}
\hline \multicolumn{2}{|c|}{ Dados sobre os filtros } & Número de poços & $\%$ \\
\hline \multicolumn{2}{|c|}{ Não há filtro } & 19 & 20,9 \\
\hline \multirow{3}{*}{ Com informações } & Diâmetro & 12 & 13,2 \\
\hline & Abertura & 0 & 0 \\
\hline & $\begin{array}{c}\text { Completas (diâmetro e } \\
\text { abertura) }\end{array}$ & 48 & 52,7 \\
\hline \multicolumn{2}{|l|}{ Sem informações } & 12 & 13,2 \\
\hline & & Total - 91 & 100 \\
\hline
\end{tabular}

O pré-filtro é constituído por material granular colocado entre a parede do poço e o revestimento e tem a função, junto com o filtro, de evitar o carreamento de partículas para o interior do poço. De acordo com os dados obtidos, em $69,2 \%$ (63 poços) foi utilizado préfiltro e em $30,8 \%$ não existiam informações quanto a sua utilização, ou ele não havia sido empregado. Como materiais empregados predominaram amplamente aqueles com granulometria de 5 a $20 \mathrm{~mm}$ ( 26 poços) e em seguida, aqueles com 5 a $8 \mathrm{~mm}$ ( 8 poços). 


\subsubsection{CARACTERÍSTICAS dE USO E EXPLOTAÇÃO}

\section{- TESTES de desenVOLVIMENTO E PRODUÇÃo dOS POÇOS}

Após a instalação da coluna de tubos e filtros, deve ser procedido o desenvolvimento do poço até que a turbidez e a concentração de areia estejam dentro dos limites admíssiveis (ABNT NT-1290). A operação de desenvolvimento é fundamental para o perfeito acabamento do poço e para Ihe assegurar o melhor rendimento. Em rochas fraturadas, ela permite a desobstrução de fraturas preenchidas pela formação da lama de perfuração, que é muitas vezes introduzida nas aberturas da rocha. (JOHNSON 1966).

Dos poços analisados, $41,8 \%$ (38 poços) possuíam informações sobre o teste de desenvolvimento, em $3,3 \%$ (3) ele não foi realizado e em $54,9 \%$ não existiam dados. Em relação aos poços que continham informações foram utilizados no teste de desenvolvimento: compressor $(21,1 \%, 8$ poços), moto-bomba $(44,8 \%, 17$ poços), bomba $(13,2 \%, 5$ poços), compressor e moto-bomba (13,2\%, 5 poços), pistão e caçamba $(2,6 \%, 1$ poço), pistão e compressor $(5,2 \%, 2$ poços). O tempo de duração dos ensaios de desenvolvimento apresentou grande variação, desde 1 até 95 horas.

Os testes de bombeamento têm basicamente duas funções (JOHNSON 1966). A primeira é avaliar o desempenho do poço, definindo a sua capacidade de produção (vazão ótima ou de explotação), o regime de explotação e o equipamento de bombeamento do poço. A outra é determinar as características hidrodinâmicas do aqüifero, que para aqüíferos fraturados ainda é uma questão bastante discutida, não existindo até o momento uma metodologia estabelecida.

A norma NBR-588/1990 recomenda que, após a conclusão de cada poço, deve ser realizado ensaio de produção com duração mínima de 24 horas. A norma NBR-1290/1990 acrescenta que, em casos de vazão inferior a $5 \mathrm{~m}^{3} / \mathrm{h}$, o teste deve ser realizado a vazão constante, com a condição de que ocorra a estabilização do nível dinâmico durante pelo menos 4 horas. A utilização de falsos niveis dinâmicos pode provocar o aumento nos custos de instalação (bombas mais potentes e mais caras e maior metragem das tubulações colocadas no poço), maior despesa na manutenção (maior consumo de energia pelas bombas de maior potência e gastos com assistência técnica constante, já que a bomba funciona fora das especificações), e uma redução nos rendimentos dos poços (nível dinâmico fictício pode inviabilizar a indicação das bombas) (Oliveira 1994).

Com relação aos testes de bombeamento, somente $47,2 \%$ (43 poços) dos poços apresentaram informações completas (equipamento utilizado e tempo de duração). Em 7,7\% (7 poços) existiam informações sobre o equipamento empregado e em 2,2\% (2 poços) somente sobre o tempo de duração. Entre os poços que continham dados sobre a duração do teste, $82,2 \%$ (37 poços) apresentaram duração igual ou superior a 24 horas. Os 
equipamentos empregados durante os testes foram a moto-bomba ( $66 \%, 33$ poços), bomba (22\%, 11 poços) e compressor (12\%, 6 poços).

Foi observado que é prática em algumas empresas da região, a utilização do compressor em ensaios de produção. $O$ ar comprimido pode ser usado eficientemente no desenvolvimento do poço, mas a sua utilização entretanto, na execução do teste final de bombeamento do poço, não é recomendada pelo fato de ser praticamente impossivel estabelecer 3 ou 4 etapas de vazão, manter o controle da vazão e efetuar medidas do nivel de água (FCTH 1988). O uso da bomba submersa é recomendável, pois permite maior constância nas vazões durante o teste (Barros 1987).

Com base nos dados de vazão foi possivel dividir os poços em classes:

$>4,4 \%$ com vazão até $1 \mathrm{~m}^{3} / \mathrm{h}$;

$>29,7 \%$ com vazão entre 1 e $5 \mathrm{~m}^{3} / \mathrm{h}$;

$>26,4 \%$ com vazão entre 5 e $10 \mathrm{~m}^{3} / \mathrm{h}$;

$>19,8 \%$ com vazão entre 10 e $20 \mathrm{~m}^{3} / \mathrm{h}$;

$>8,8 \%$ com vazão superior a $20 \mathrm{~m}^{3} / \mathrm{h}$.

Os $11 \%$ restantes correspondem a poços desativados e abandonados. Os valores de vazão considerados foram aqueles presentes nas fichas técnicas dos poços, independentemente do tempo de bombeamento e equipamento utilizado. Foram considerados dados de vazão de alguns poços desativados e abandonados por causas diversas, desde que não tenha sido por queda de vazão.

O levantamento de dados revelou que as vazões descritas em fichas técnicas muitas vezes não são reais. Por exemplo, no poço P20 a vazão descrita na ficha técnica é de 12 $\mathrm{m}^{3} / \mathrm{h}$ determinada em ensaio de desenvolvimento de 3 horas com compressor. Entretanto, de acordo com o responsável pela sua operação, este valor é na verdade de $7 \mathrm{~m}^{3} / \mathrm{h}$ e se baseia no tempo que é necessário para se completar a reservação. A questão é que os valores de vazão obtidos em testes de bombeamento de tempo curto (algumas horas) representam, muitas vezes, somente a capacidade da bomba ou do compressor utilizados, obtendo-se uma falsa estabilização do nivel estático. Os resultados obtidos desta forma não são úteis no correto dimensionamento da bomba e da explotação do poço.

\section{- UNIDADE DE BOMBEAMENTO}

Foram verificados os equipamentos de bombeamento dos poços em explotação e dos desativados que ainda possuíam bomba. Somente em 1 poço a bomba era do tipo injetora e em todos os demais elas eram centrífugas submersas. O uso generalizado da bomba submersa não é apenas uma função da quantidade de água a ser bombeada, mas também do menor consumo de energia, dos menores comprimentos de tubos dentro do poço e da economia com a dispensa de abrigos para a bomba (Pacheco 1984). 
Em dois casos, proprietários de poços informaram problemas de queima regular da bomba submersa. Em um deles, a análise realizada por um técnico indicou que possivelmente se devia à inadequação dos filtros e pré-filtros às características do aqüifero, levando à entrada de areia na bomba. Outra origem para estes tipos de problema, pode ser a colocação de uma bomba superdimensionada para o poço.

\section{- Regime de eXPLotação}

O levantamento junto aos proprietários ou usuários dos poços tubulares sobre o seu regime de explotação foi bastante dificil, pois freqüentemente os poços utilizam o sistema de acionamento automático feito através de chave-bóia instalada na reservação. Por isso, em apenas $52,7 \%$ dos poços o tempo de funcionamento diário pôde ser obtido. Com os dados disponíveis (tabela 16) foi possível distinguir dois grupos. As chácaras e condomínios pequenos apresentam regime de funcionamento diário de 10 minutos até 5 horas, com média de 2 horas. Nos grandes condomínios, onde a demanda por água é muito maior, o regime varia de 6 chegando até 24 horas, com valor médio de 10 horas.

Tabela 16. Regime de explotação diária dos poços.

\begin{tabular}{|c|c|c|c|c|c|c|c|c|c|c|c|c|c|c|c|c|c|c|}
\hline $\begin{array}{l}\text { Número } \\
\text { de horas } \\
\text { diárias }\end{array}$ & $\begin{array}{l}\text { Até } \\
1 / 2\end{array}$ & 1,5 & 2,5 & 3 & 3,5 & 4 & 5 & 6 & 7 & 9 & 11 & 12 & 13 & 14 & 16 & 20 & 24 & Total \\
\hline $\begin{array}{c}\text { Número } \\
\text { de } \\
\text { poços }\end{array}$ & 3 & 3 & 1 & 2 & 1 & 5 & 1 & 9 & 3 & 4 & 1 & 5 & 1 & 2 & 1 & 1 & 5 & 48 \\
\hline
\end{tabular}

\section{- Dados de qualidade da ÁGua}

Em $56 \%$ dos poços analisados, de acordo com os proprietários, já haviam sido realizadas análises de água. Entretanto, os resultados das análises a que tivemos acesso ficaram restritos àqueles realizadas pelas empresas de perfuração após a conclusão da obra e representam 25,3\% (23 poços) do total de poços. Destes laudos, a água de 1 poço foi considerada potável e a de 22 poços como não potável, de acordo com a portaria 036 do Ministério da Saúde. Neste casos, os principais parâmetros considerados fora dos padrões de potabilidade foram $\mathrm{pH}$, turbidez, ferro total, coliformes totais e fecais.

A caracterização físico-química e qualitativa das águas será realizada em outro capítulo e, portanto, não será discutida aqui. Entretanto, é importante ressaltar que valores altos de coliformes totais e fecais em muitas análises, possivelmente refletem a ausência de preocupações higiênicas durante a perfuração dos poços, que aparece nos resultados das análises de água realizadas após a conclusão do poço. 
Com relação à reservação, somente 2 poços $(2,2 \%)$ utilizam caixas de amianto $(1.000$ e 2.000 L) e 14 poços $(15,4 \%)$ reservatórios, em geral, de cimento ao nível do solo, semi-enterrados e enterrados $(5.000$ a $15.0000 \mathrm{~L})$. Nos demais predominam reservatórios elevados do tipo taça ou cilíndrico, com volumes que variam de 10.000 a $60.000 \mathrm{~L}$.

O estado de conservação da reservação é uma aspecto importante para a qualidade da água, especialmente quando o seu principal uso é domiciliar. A pesquisa quanto ao estado destes reservatórios baseou-se em informações dos proprietários, sendo complementada por observações no local. Foram avaliados os reservatórios de 60 poços. Em $90 \%$ dos casos, o resultado foi considerado bom a regular e em 10\%, como ruim. Os principais problemas observados foram a ausência de cuidados quanto à limpeza regular dos reservatórios elevados de grande volume e a ausência de proteção (tampa) superior em caixas de cimento. Em um caso foi encontrado um rato morto dentro de um reservatório de cimento semi-enterrado.

\section{- Uso da ÁGua}

A água subterrânea, na área de estudo, tem como uso predominante o domiciliar respondendo por $59,3 \%$ dos casos (tabela 17). Considerando-se somente os poços em explotação ela representa $79,4 \%$. Em 3 poços, o uso é comercial (churrascaria, motel e posto de serviço) e em 2 poços, industrial (fábrica de piscinas e indústria de asfalto). Nos 7 poços do Condomínio Mini-Chácaras o uso é domiciliar e comercial, já que existe um considerável número de estabelecimentos comerciais dentro do condomínio. Em outros 2 poços, os usos são domiciliar e em pequena atividade agrícola e domiciliar e avicultura.

Tabela 17. Tipos de usos da água dos poços tubulares.

\begin{tabular}{|c|c|c|}
\hline Uso da água & Número de poços & $\begin{array}{c}\% \text { em relação aos poços em } \\
\text { funcionamento) }\end{array}$ \\
\hline Domiciliar & 54 & $59,3(79,4)$ \\
\hline Domiciliar e Comercial & 7 & $7,7(10,3)$ \\
\hline Comercial & 3 & $3,3(4,4)$ \\
\hline Industrial & 2 & $2,2(2,9)$ \\
\hline Agrícola & 1 & $1,1(1,5)$ \\
\hline Sem informação & 1 & $1,1(1,5)$ \\
\hline Nenhum & 23 & 25,3 \\
\hline (poços que năo estão em funcionamento) & & 100 \\
\hline Total & 91 & \\
\hline
\end{tabular}

A pesquisa com relação aos usuários revelou que a absoluta maioria depende exclusivamente da água subterrânea (tabela 18). As estimativas indicam que na área 
estudada cerca de 18.500 pessoas dependem da água subterrânea captada através de poços profundos. Deste total, mais de $95 \%$ dos usuários está concentrada nos condomínios.

Tabela 18.Tipos de usuários de água de poços tubulares.

\begin{tabular}{|c|c|c|}
\hline \multirow{2}{*}{$\begin{array}{c}\text { Uso exclusivo de água de poços } \\
\text { tubulares }\end{array}$} & Condominios & 27 \\
\cline { 2 - 3 } & $\begin{array}{c}\text { Outros (pequenas indústrias, motel, } \\
\text { posto de serviço, restaurante) }\end{array}$ & 7 \\
\cline { 2 - 3 } & Condomínios & 6 \\
\hline Uso de fontes complementares aos & Chácaras & 2 \\
\cline { 2 - 3 } & & 2 \\
\hline
\end{tabular}

Os condomínios Vivendas Campestre e Jardim América dependem de água transportada por caminhões, devido à problemas de queda de vazão dos poços. Em duas chácaras a complementação é realizada através da água de fontes. No caso dos 3 poços localizados no assentamento Sobradinho II, eles encontram-se desativados, sendo atualmente o abastecimento da população realizado por águas superficiais.

Em apenas 3 poços a água captada era submetida a tratamento com a utilização de filtros. Em geral, predomina entre os usuários a crença de que a água subterrânea é totalmente protegida e de qualidade muito boa. Este fato na maioria dos casos é verdadeiro, desde que as obras de captação sejam corretamente construídas, adotando perímetros e medidas de proteção sanitária.

\section{- manutenção}

A manutenção programada de poços pode melhorar o desempenho de um poço, aumentando a sua vida útil. Embora uma boa parte dos proprietários reconheça a importância de uma manutenção adequada, na prática ela é pouco realizada.

O levantamento revelou que em apenas 2 poços $(2,2 \%)$ é feita a manutenção preventiva. A maior preocupação dos proprietários em relação à manutenção dos poços é com as bombas, já que elas afetam diretamente a produtividade dos poços. Entretanto, os poços propriamente ditos, como não são visiveis, merecem atenção apenas quando a quantidade ou qualidade das águas é afetada seriamente, o que muitas vezes torna impossivel a sua recuperação.

É necessária portanto, a conscientização por parte dos usuários de água subterrânea de que para manter a estrutura dos poços é muito importante realizar periodicamente a avaliação dos filtros e do revestimento, em função de problemas de incrustação e corrosão, a manutenção do registro de operação dos poços com informações sobre taxas de bombeamento e rebaixamento do nível de água, total de horas de operação, potência utilizada e análise da água, entre outros. Estes registros podem proporcionar uma sólida 
base para decidir os procedimentos necessários para se alcançarem os melhores resultados quanto à sua manutenção, otimizando a operação do sistema (JOHNSON 1966).

\subsubsection{ASPECTOS DE PROTEÇÃO E CAPTAÇÃO DOS POÇOS}

Um dos aspectos mais discutidos atualmente com relação às águas subterrâneas é da sua vulnerabilidade às diversas fontes de poluição e/ou contaminação, principalmente de origem antrópica. Esta questão se torna ainda mais séria, quando se trata de águas cujo principal uso é o domiciliar. Um aspecto muitas vezes negligenciado nestes casos é a contaminação direta, ou seja, aquela decorrente de deficiências técnicas na construção dos poços. Por isso, serão descritos a seguir os principais problemas levantados com relação à proteção sanitária dos poços que podem eventualmente torná-los fontes pontuais de contaminação e/ou poluição.

Do total de poços cadastrados, $94,5 \%$ apresentaram alguma deficiências quanto aos aspectos de proteção sanitária. Os principais problemas construtivos observados foram a locação, cimentação e a proteção superior.

\section{- Locação}

Existem diferentes estudos que recomendam distâncias minimas entre poços e possiveis fontes de poluição e/ou contaminação. As fontes potencialmente poluidoras dos aqüiferos na área de estudo são os postos de serviço e a disposição de esgotos no solo. As distâncias mínimas recomendadas de um poço a possiveis fontes de contaminação relacionadas à disposição in situ de efluentes domésticos são (FCTH 1988):

- fossa comum que recolhe esgoto direto: $30 \mathrm{~m}$;

- drenos comuns ou fossa seca: $23 \mathrm{~m}$;

- tanque séptico ou condutos de esgoto cerâmico com juntas estanques: $15 \mathrm{~m}$;

A absoluta maioria dos usuários de poços, de acordo com os dados levantados, tanto no meio rural como na área dos condomínios, utilizam a fossa como destino final dos resíduos líquidos domésticos. Embora alguns condomínios, através das suas administrações, orientem a construção de fossas sépticas, é possível afirmar que não existe um controle em relação à sua utilização. Nos condomínios e invasões de pessoas de baixa renda, no qual o crescimento é descontrolado, a situação é ainda mais complexa. Apenas 5 poços estão localizados em áreas atendidas pelo serviço público de esgotamento sanitário. São 2 poços localizados na cidade de Sobradinho e os 3 poços desativados da CAESB no assentamento Sobradinho II.

Entretanto, em $93,4 \%$ dos casos, a locação dos poços foi considerada adequada. Alguns condomínios reservam lotes só para o funcionamento do poço. Apenas 2 poços 
estão localizados próximos a postos de serviços, 3 apresentaram em volta da área dos poços acúmulo de material de construção e em 1 poço acúmulo de lixo.

\section{- cimentação}

A norma NBR-1290/1990 recomenda a perfuração inicial com um diâmetro maior que o do poço, a fim de que possa ser colocada uma pasta de cimento, entre o tubo de revestimento e a parede de perfuração. Ela tem a função de isolar o revestimento tubular de modo a prevenir infiltrações verticais ao longo de sua superfície externa, proporcionar a estabilidade do material envolvente e atuar como camada protetora à corrosão do tubo de revestimento (Barros 1987).

Apenas $36,3 \%$ dos poços apresentaram cimentação (tabela 19), cujas profundidades variaram de 0 até $36 \mathrm{~m}$, sendo que em 48,5\% dos casos (16 poços) o valor foi de 1 até 11 $\mathrm{m}$. Em 2 poços abandonados as profundidades de cimentação foram de 11,3 a $12 \mathrm{~m}$ e de 15,3 a $16 \mathrm{~m}$. As observações de campo indicam que possivelmente a grande maioria dos poços que não apresentam dados sobre a cimentação é por ela não ter sido feita.

Tabela 19. Característica dos poços avaliados em relação à cimentação.

\begin{tabular}{|c|c|c|}
\hline Cimentação & Número de poços & $\%$ \\
\hline Possuem cimentação & 33 & 36,3 \\
\hline Não possuem & 13 & 14,3 \\
\hline Sem informação & 45 & 49,4 \\
\hline & Total - 91 & 100 \\
\hline
\end{tabular}

\section{- Proteção superior}

Entre os elementos de proteção superior das captações, foram observados aspectos técnicos deficientes quanto à laje de proteção e à tampa.

A norma NBR-1290/1990 afirma que deve ser construida uma laje de concreto envolvendo o tubo de revestimento com declividade do centro para a borda, espessura mínima de $15 \mathrm{~cm}$ e área não inferior a $1,0 \mathrm{~m}^{2}$. Acrescenta ainda que a coluna de tubos deve ficar saliente no mínimo $50 \mathrm{~cm}$ sobre esta laje, que tem a função de impedir o acúmulo de água ao redor do poço.

As observações de campo mostraram que somente $9,9 \%$ dos poços apresentaram altura dos tubos superior a $50 \mathrm{~cm}$. Em 17,6\% dos casos este aspecto não pôde ser observado. Com relação à laje de proteção, em 13,2\% (12 poços) dos poços não foi possivel observá-la e em $69,2 \%$ (63 poços) ela estava ausente. Entre os 16 poços (17,6\% do total de poços) no qual a laje estava presente, em 11 ela não possuía declividade ou 
havia sido feita de forma irregular, sem atender as dimensões minimas. Em apenas 5 poços ela foi construida corretamente.

Após concluidos todos os serviços, o poço deve ser lacrado com chapa soldada e tampa rosqueável (NBR-1290/1990). Esta tampa tem a função de impedir a entrada de corpos sólidos ou líquidos que possam contaminar a água dos poços. Foi observada a tampa em 81 poços, dos quais $73,6 \%$ (67 poços) apresentaram tampa de ferro e 2,2\% (2 poços) de PVC consideradas corretamente colocadas e adequadas. Em 13,2\% dos poços elas eram inadequadas porque estava aberta ( 1 poço), com buraco ( 1 poço), deslocada ( 5 poços) ou ausentes (5 poços). A foto 1 mostra um poço com a tampa deslocada, e que apresenta deficiência técnicas quanto à laje sanitária e altura minima da boca do poço. $\mathrm{Em}$ $11,0 \%$ dos casos (10 poços) não foi possivel observar a tampa.

Um aspecto interessante a se destacar é que a extremidade superior dos poços em $45,1 \%$ (41 poços) dos casos fica em caixas de cimento que estão parcialmente ou totalmente abaixo do solo. Nestas caixas, a falta de drenos possibilita a acumulação de águas superficiais que facilmente podem atingir o interior da boca dos poços, podendo afetar a qualidade das águas. Em apenas 10 poços, a tampa destas caixas foi considerada bem vedada. Em 3 poços vazamentos na tubulação que saia do poço encheram a caixa de água. Dentro destas caixas, mesmo naquelas que não estão acima do solo, é comum o acúmulo de material de construção e plástico (foto 2).

\subsubsection{Poços abandonados e desativados}

Em relação aos 10 poços desativados cadastrados observou-se que as causas de desativação foram queda de vazão (5 poços), falta de energia elétrica (1 poço), transferência da empresa (1 poço) e substituição da água subterrânea pela superficial ( 3 poços). Deste total, 3 poços foram desativados com revestimento e equipamento de bombeamento (bomba submersa) e 3 com o revestimento e sem equipamento (em um poço não foi possivel observar este aspecto). Quando os poços são desativados os revestimentos e filtros sofrem um processo de corrosão, comportando-se como condutores de contaminação para o aqüifero e a presença da unidade de bombeamento no interior do poço, além de deteriorá-la, afeta a qualidade da água subterrânea desencadeando problemas de ferretização (Pacheco 1984). Foi observado ainda que 3 destes poços estavam sem tampa.

Foram identificados na área 7 poços abandonados, ou seja, que nunca foram explotados por secos ou apresentarem vazões inferiores a $0,8 \mathrm{~m}^{3} / \mathrm{h}$. Em relação às condições de abandono da obra, foi verificado que 3 poços estavam cobertos por uma camada de cimento, 1 poço havia sido preenchido por solo, 1 poço possuía uma tampa de 


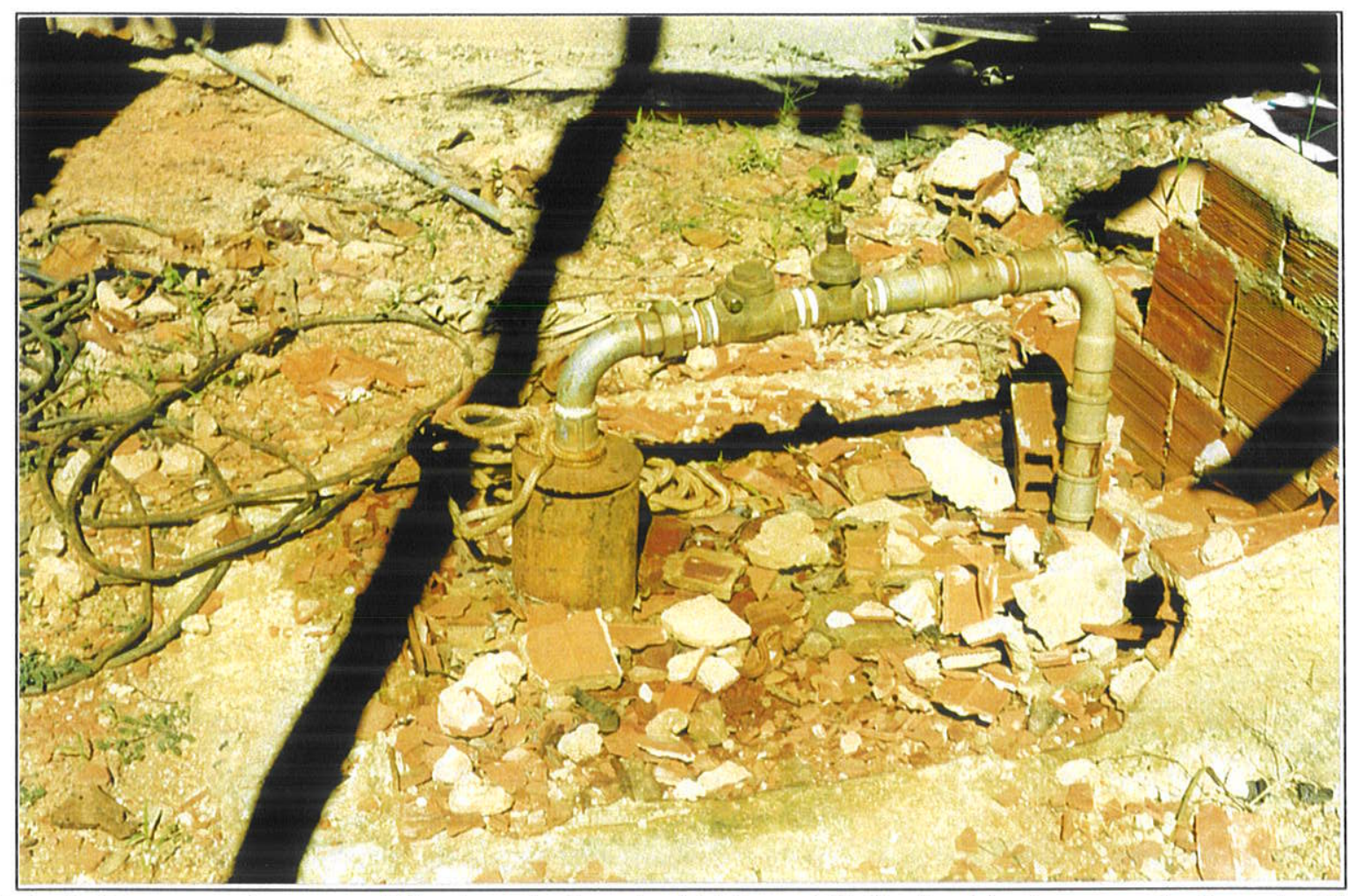

Foto 1. Poço com tampa mal fixada e deslocada. Existem deficiências técnicas construtivas devido à ausência da laje de proteção sanitária e a saliência do tubo de revestimento interno, que não obedece à altura mínima de $50 \mathrm{~cm}$ recomendada pela ABNT (1990).

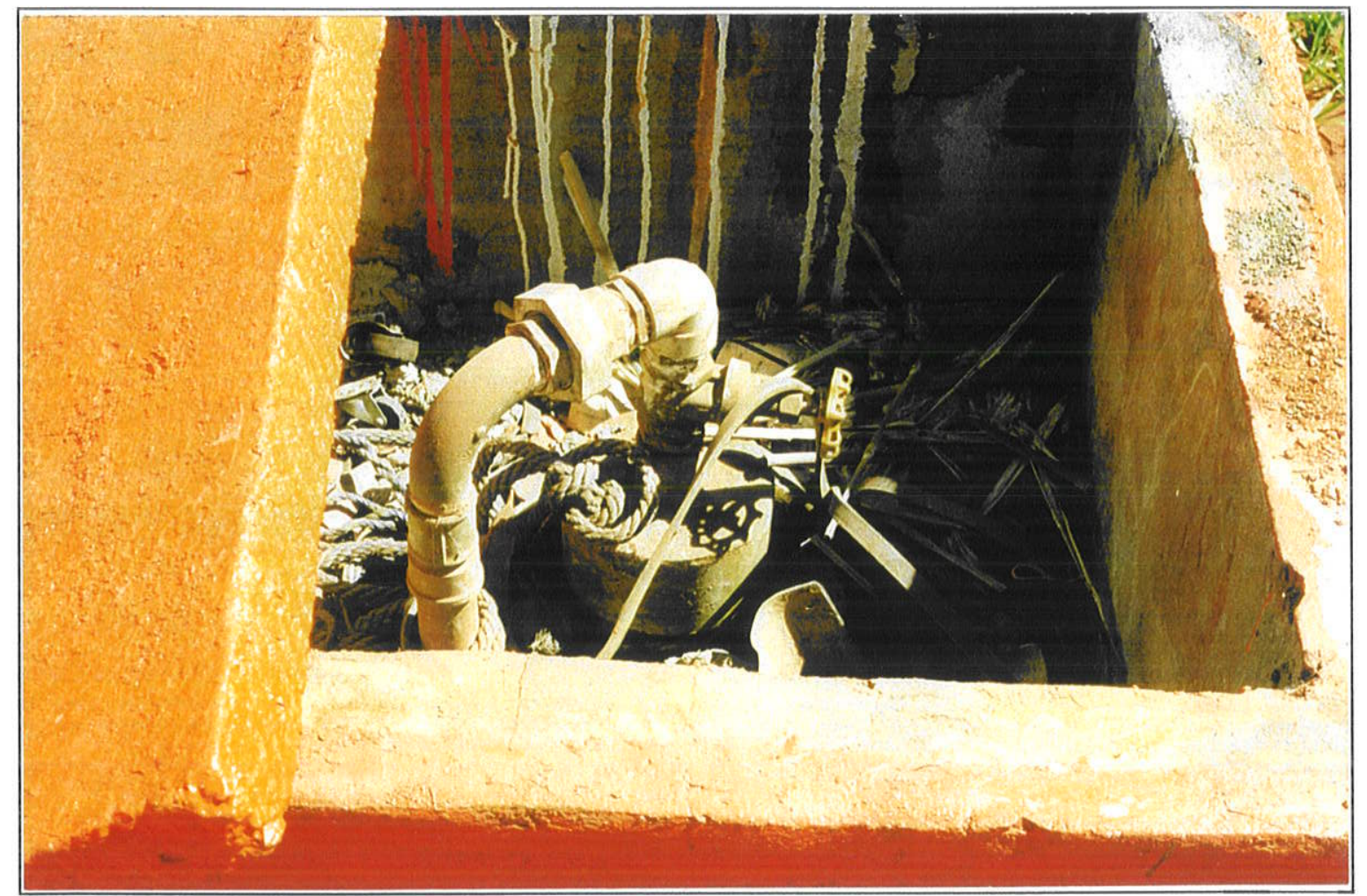

Foto 2. Poço apresenta a sua extremidade superior (boca do poço) localizada dentro de caixa de cimento parcialmente abaixo do solo em que existe acúmulo de lixo e sucata. 
ferro soldada na extremidade do tubo de boca, 1 poço possuía apenas uma tampa de PVC rosqueável e 1 poço não pôde ser observado. É muito importante que o processo de abandono priorize a vedação total do poço de modo a prevenir a contaminação do aqüífero e evitar a possibilidade de acidentes de pessoas.

Além dos poços desativados e abandonados cadastrados, foram incluídos no banco de dados 6 poços na mesma situação, para os quais não havia qualquer informação sobre as características técnicas da obra. Estes poços têm em comum o fato de serem resultado de um processo inadequado de abandono ou desativação, não apresentando em geral, a tampa e laje de proteção sanitária. Por isso, representam um risco com relação à proteção do aqüífero.

De modo geral, se observa na área de estudo que não são tomadas medidas adequadas de desativação e abandono. A foto 3 mostra um poço desativado sem qualquer tipo de proteção sanitária. Neto e Ricaldi (1993) recomendam em caso de desativação temporária do poço, a colocação de tampa de aço soldada, a verificação do estado da cimentação no espaço entre o revestimento e a parede do poço, e a execução de cloração para evitar a possibilidade de proliferação de bactérias que possam afetar a integridade dos revestimentos e filtros. No caso de abandono definitivo, recomendam que os poços devem ser preenchidos com brita grossa e solução clorada. O preenchimento se dará até $5 \mathrm{~m}$ abaixo do tubo de revestimento, e daí em diante deverá ser executada cimentação.

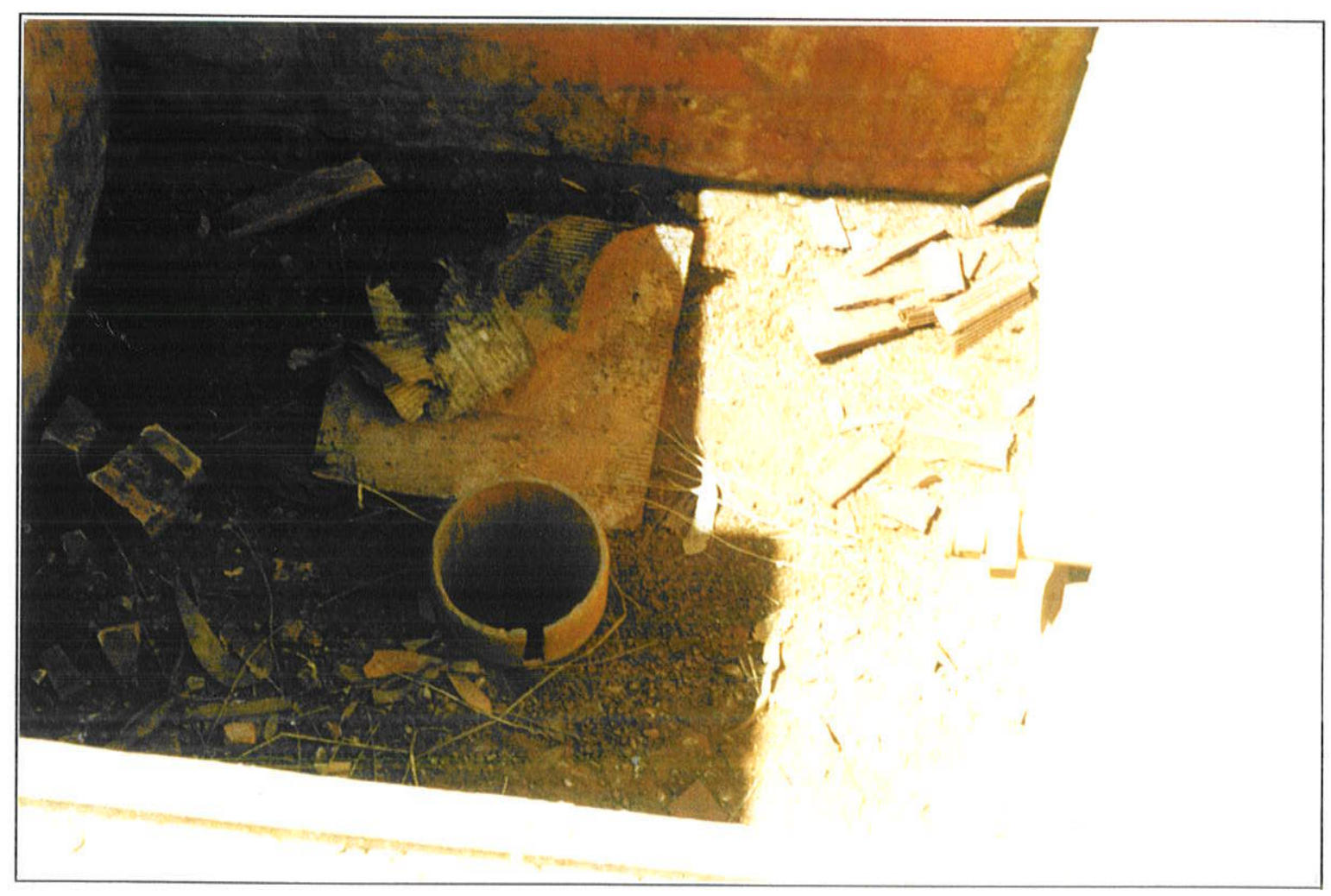

Foto 3. Poço sem laje sanitária e desativado sem qualquer tipo de preocupação sanitária evidenciada pela falta de vedação. 


\subsection{Poços Rasos}

Foi inventariado um total de 79 poços rasos na área. O poço raso, conhecido também por cacimba, poço escavado ou cisterna (menos usado), é a mais antiga obra de captação de água subterrânea utilizada pelo homem e consiste, essencialmente, em escavar um buraco no solo para obter água. Desde a sua introdução, houve um avanço significativo nas técnicas e materiais empregados na sua construção. A sua grande utilização se deve à simplicidade de execução e baixo custo.

As limitações que, em geral, são impostas para uso dos poços rasos estão relacionados a dois aspectos (Piuci 1986). Um deles diz respeito à vuinerabilidade a que estão sujeitos pela contaminação antropógena e o outro está relacionado às limitações quanto às vazões. Em relação à vulnerabilidade destas captações Custódio \& Llamas (1976) (apud Duarte \& Kanehisa 1986) identificam duas fontes de poluição. A potencial está relacionada à conservação das captações como, por exemplo, a falta de lajes de proteção e tampas de vedação, que permitem a introdução de agentes estranhos, tais como pequenos animais e materiais. As fontes efetivas são os sistemas sépticos e as fossas, pois compartilham um mesmo meio cujo único fator de proteção é a distância entre as fontes de poluição e as captações, e uma possivel auto-depuração da carga poluente associada a fenômenos físicos (filtração mecânica), químicos (oxidação, redução, precipitação e coprecipitação) e bioquímicos (biodegradação por microorganismos do solo).

\subsubsection{SituAÇÃo ATUAL}

Do total de poços rasos levantados, $94 \%$ (74 poços) estão em explotação. Dois poços estavam e outros 3 são de uso eventual, dos quais dois ficam em condomínios e são utilizados, principalmente, durante o período de seca em jardins e para realizar a lavagem de casas.

Os poços de uso eventual e desativados localizam-se, na sua grande maioria, em condomínios que, com o aumento da demanda por água, abandonaram a utilização dos poços rasos e adotaram os poços tubulares. Em alguns destes condomínios, os poços rasos continuam existindo, mas são usados de forma complementar.

Em $18 \%$ dos casos a água dos poços rasos era complementada por água de nascentes $(4 \%)$, córregos $(5 \%)$, poços tubulares $(6 \%)$, chafariz da CAESB (1\%) e pelo uso exclusivo do poço profundo $(2 \%)$. 


\subsubsection{CARACTERÍSTICAS TÉCNICAS dE CONSTRUÇÃo}

\section{- escavação}

A escavação dos poços rasos, na área de estudo, é realizada pelos chamados "poceiros" que, em geral, trabalham em duplas. Os instrumentos empregados são bastante simples e consistem de pá, picareta e/ou ponteira. No início da execução do trabalho, apenas um poceiro participa até a profundidade onde ele consegue jogar a terra escavada para fora do buraco. A partir daí, é instalado um sarrilho com manivela manual, que é operado pelo outro poceiro, que com balde retira a terra do poço. A forma preferencial de escavação é a circular, segundo Piuci (1986), devido à simplicidade e por oferecer maior resistência ao desmoronamento.

As condições de execução dessas obras são bastante precárias, não só em termos de instrumentos empregados, mas também no aspecto de segurança dos trabalhadores, que reflete a falta de especificações técnicas na obra. Além do desconforto do trabalho em local de circulação de ar restrita, com calor e pequeno espaço físico, existe o risco permanente de desmoronamento das paredes durante a escavação. Quando a escavação apresenta elevado risco de desmoronamento, é utilizado um revestimento que poderá ser provisório ou definitivo, que freqüentemente é composto por estacas, vigas de madeira ou anéis pré-moldados de concretos, conhecidos como manilhas.

\section{- DIÂMETRO}

Os poços rasos apresentaram, em $77 \%$ dos casos (61 poços), diâmetros entre 0,90 e $1,20 \mathrm{~m}$, que se relacionam principalmente ao uso como revestimento de manilhas, que são disponiveis nestes diâmetros. Apenas um poço raso apresentou diâmetro inferior a $90 \mathrm{~cm}$ $(75 \mathrm{~cm}$ ). Treze poços apresentaram valores que variam de 1,30 até 2,30 $\mathrm{m}$. Três poços rasos haviam sido construídos de forma retangular com dimensões de 1,4×1,7, 1,6x1,6 e $3,4 \times 3,7 \mathrm{~m}$. Em outro caso não foi possivel medir as dimensões por se tratar de um buraco aberto aleatoriamente no chão, com forma irregular.

\section{- Profundidade}

A profundidade dos poços rasos é função essencialmente das condições hidrogeológicas do local. A escavação prossegue poucos metros após ser atingido o nivel freático em função das condições de trabalho do "poceiro", que são muito dificultadas pela água do aqüifero. Dessa forma, incorpora-se à obra deficiências inerentes às limitações técnicas disponiveis (Piuci 1986), originando os problemas relativos a contaminação e baixas vazões dos poços. 
Com relação às profundidades dos poços informadas pelos proprietários, em apenas um caso ela era desconhecida. Nos demais observou-se que $57 \%$ (45 poços) tinham até 10 $\mathrm{m}$ de profundidade e $34 \%$ (27 poços) entre 11 e $20 \mathrm{~m}$. Apenas 6 poços rasos possulam profundidade superior a $20 \mathrm{~m}$, chegando a um valor máximo de $25 \mathrm{~m}$.

Como em geral a altura do nível de água dentro dos poços é pequena, em torno de 2 $\mathrm{m}$, torna-se necessário o aprofundamento dos poços nos períodos de estiagem, de forma a garantir pelo menos a explotação das reservas reguladoras do aqüifero.

\section{- Revestimento}

O revestimento dos poços rasos é uma das partes mais importantes da obra de captação, pois ela desempenha as funções de evitar o desmoronamento das paredes, durante e após a escavação, proporcionar a proteção do poço de infiltrações superficiais, além de permitir e facilitar a inspeção e limpeza do poço (Piuci 1986). A Unicef (1988) (apud Cavalcanti 1996) recomenda que as paredes dos poços sejam revestidas com tijolos, cimento ou tubos de concreto até cerca de $3 \mathrm{~m}$ de profundidade para evitar a infiltração de águas superficiais.

De modo geral, neste tipo de obra de captação é comum a utilização de diferentes materiais tais como pedras, tijolos, concreto, cerâmica, aço ou ainda revestimentos mistos, que usam os vários materiais. Entretanto, nos poços rasos analisados, o único tipo de revestimento empregado é o concreto. $\mathrm{Na}$ área de estudo foram observados os seguintes aspectos em relação ao revestimento:

- poços totalmente revestidos: $35(44,5 \%)$

- poços parcialmente revestidos: $10(12,5 \%)$

- poços sem revestimento: 34 (43\%).

$O$ revestimento em concreto pode ser feito basicamente com segmentos de anéis pré-moldados (manilhas) ou pela concretagem in situ. Pelo alto custo da concretagem in situ, a opção tem sido feita pela utilização das manilhas, que são segmentos anelares com diâmetros, em geral, de 0,9 a $1,3 \mathrm{~m}$, que apresentam encaixe tipo macho-fêmea para acoplamento.

Entre os poços parcialmente revestidos, metade deles possui revestimento só na parte inferior, o que reduz a proteção do aqüifero de águas superficiais. Dois poços, entretanto, não foram totalmente revestidos porque a sua parte inferior foi perfurada com ponteira na rocha (C58 e C69). A ausência de revestimento em algumas obras reflete a falta de conhecimento dos aspectos mais básicos de higiene e de proteção do recurso hídrico, e o baixo poder econômico dos usuários.

O fundo dos poços rasos analisados não é revestido. Naqueles onde toda a profundidade perfurada é revestida com manilhas e as paredes laterais estão totalmente 
fechadas, a água entra somente pelo fundo do poço. Embora este fato restrinja as vazões dos poços, ela garante o aproveitamento das porções um pouco mais profundas do aqüifero e portanto, menos vulneráveis à contaminação.

\section{- Acabamento}

É muito importante que a parte superior do poço acima da superfície seja bem construída, de modo a proteger o aqüífero e a água do poço e propiciar segurança ao usuário (Piuci 1986). É recomendável que esta proteção, geralmente construida em alvenaria com argamassa de cimento e com tampa de cimento bem vedada, fique pelo menos $30 \mathrm{~cm}$ acima do solo (Nogami 1967).

Com relação à proteção superior dos poços rasos, em 9 casos $(11 \%)$ ela estava ausente. Nas demais foram empregados os seguintes materiais: 30 poços $(38 \%)$ apresentaram cimento e tijolo e 40 poços (51\%) manilhas. $E$ apenas 38 poços, que representam $48 \%$ do total, apresentaram altura da proteção superior maior que $30 \mathrm{~cm}$. Esta altura mínima garante uma proteção adequada contra enxurradas, acidentes e queda de pequenos animais. Em um caso, por exemplo, o proprietário relatou que uma enxurrada havia enchido de lama a cacimba, obrigando-o a retirar toda a água até secá-la.

E fundamental a colocação de uma tampa, que ofereça uma boa vedação, sobre a proteção superior ou o revestimento. É preferivel que a tampa seja de concreto, pois as de madeiras não mantêm a estanqueidade, e que seja feita uma abertura na tampa para permitir a introdução do tubo de sucção da bomba (Nogami 1967). Entre as tampas observadas, aquelas consideradas adequadas por oferecerem boa vedação utilizavam cimento $(45,5 \%)$ e ferro $(2,5 \%)$. Entre aquelas consideradas inadequadas (43\%), existiam os mais variados tipos de materiais como madeira, cimento quebrado, placas de ferro, telhas e tábuas de madeira. No restante dos casos a tampa estava ausente. Em um poço foi encontrado um animal morto dentro da água, devido à inexistência de uma tampa adequada.

\section{- LAJE}

A laje de proteção deverá ser fundida em concreto armado com ferragem, possuir espessura de 10 a $15 \mathrm{~cm}$, com dimensões laterais e acabamento que impossibilitem a infiltração de águas, mesmo aquelas retiradas do próprio poço (Piuci 1986). Esta laje estava presente em somente 22 poços rasos, sendo que deste total, em apenas 14 ela havia sido bem construída com as dimensões mínimas e colocação regular do cimento. 


\section{- Equipamento de Bombeamento}

Com relação ao equipamento de explotação, $82 \%$ dos poços são equipados, $13 \%$ são manuais e outros não estão equipados (5\%). Entre aqueles equipados, a grande maioria utiliza bombas submersas (86\%), que são, em geral, de baixa potência (0,5 a $1 \mathrm{hp})$. Os poços com equipamento manual utilizam baldes ou latas, na maior parte com corda e sarrilho. As informações disponíveis sobre a profundidade das unidades de bombeamento indicam que elas são colocadas de 0,5 a $2 \mathrm{~m}$ acima do fundo poço.

O sarrilho com corda e balde é a forma mais econômica de se extrair água dos poços rasos. Entretanto, representa uma fonte de contaminação direta através de impurezas que caem pela abertura superior do poço, ou que são introduzidas pelas condições de falta de higiene nas cordas e balde, bem como do local em torno do poço (foto 4).

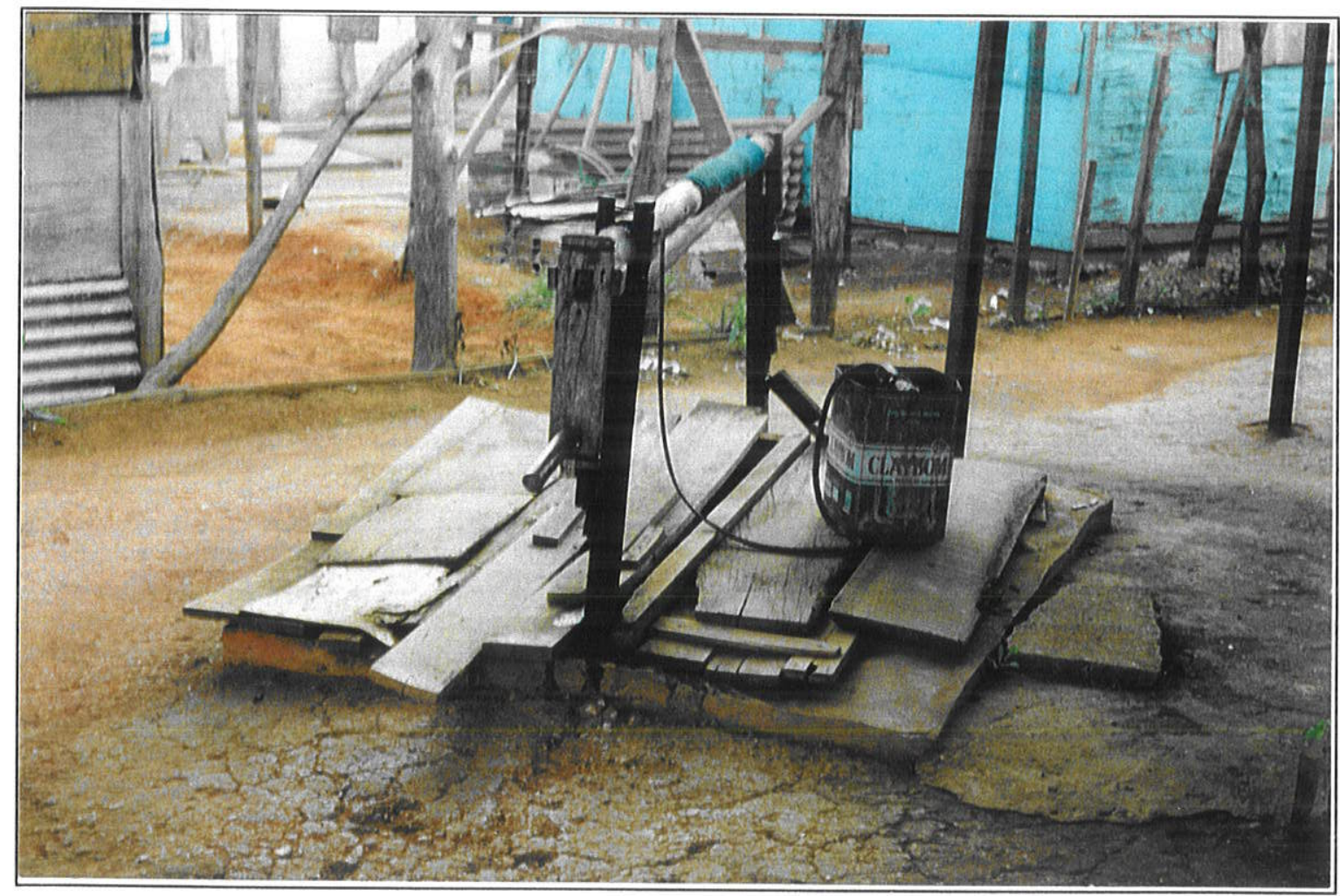

Foto 4. As condições de higiene são em geral, precárias quando se utiliza o sarrilho com corda e balde. O poço raso apresenta deficiências técnicas construtivas representadas pela ausência de laje de proteção sanitária, borda do poço praticamente ao nível do solo e tampa de madeira que não oferece boa vedação. 


\subsubsection{CARACTERISTICAS dE USO E EXPLOTAÇÃo}

\section{- Regime de explotação}

O regime de explotação diário dos poços rasos é muito variável com valores que vão desde 5 minutos a 8 horas. Entretanto, $29 \%$ dos valores observados ficaram compreendidos entre 30 minutos e 1 hora. Apenas em 12,5\% estes valores foram inferiores a 30 minutos e em $21,5 \%$ superiores a 1 hora. Em 29 poços rasos (37\%) não foi possivel determinar o número de horas de funcionamento, o que estava, em geral, relacionado à existência de sistema de chaveamento automático no poço, ou pelo fato da extração de água ser manual.

\section{- VazÃo}

A partir do número de horas de funcionamento dos poços e dos volumes das suas reservações foi possivel estimar uma vazão média de $2,2 \mathrm{~m}^{3} / \mathrm{h}$ para os poços rasos. Este valor deve ser considerado de forma cuidadosa, pois os valores de vazão apresentaram uma margem bastante significativa de variação de 0,5 a $6,6 \mathrm{~m}^{3} / \mathrm{h}$.

É importante ressaltar que os poços de alta vazão (superior a $1,5 \mathrm{~m}^{3} / \mathrm{h}$ ) são todos de pequeno diâmetro, em geral entre 0,9 e $1,4 \mathrm{~m}$, e funcionam entre 10 a 30 minutos por dia. $O$ curto período de funcionamento destes poços está condicionada à pequena espessura saturada do aqüífero atravessada pelo poço. Deste modo, o bombeamento prolongado destes poços leva rapidamente à sua exaustão. Por outro lado, os poços com vazões entre 0,5 e $1,5 \mathrm{~m}^{3} / \mathrm{h}$ apresentam grande diâmetro (superior a $1,5 \mathrm{~m}$ ) e funcionam em média durante $1 \mathrm{~h} /$ dia.

\section{- Usuários de ÁGUA de poços rasos}

Os poços rasos que se encontram em explotação atualmente na área estão concentrados principalmente na zona rural da bacia, no Núcleo Rural de Sobradinho I. De um total de 79 poços, 55 atendiam a apenas uma residência com valor médio de 6,2 habitantes/residência.

Os dados levantados indicam que cerca de 4.200 pessoas utilizam a água subterrânea captada através de poços rasos. Merecem destaque na área de estudo 4 condomínios cuja fonte exclusiva de água é realizada através de poços rasos que são o Condomínio Residencial Império dos Nobres (520 moradores), Condomínio Entrelagos (2800), Condominio RK (300) e Condomínio Residencial Mansões Colorado (192). A continuidade de explotação das águas de poços rasos nestes locais se deve, em grande parte, pelo baixo nivel de ocupação de lotes, que está em torno de $50 \%$, reduzindo o problema fossa-poço. A tendência mostrada pela história de ocupação da região é que futuramente o abastecimento nestes locais seja feito através de poços tubulares. 


\section{- AsPeCtos de uso e qualidade da ÁGUA}

A grande demanda por água dos poços rasos é para uso domiciliar em $83,5 \%$ dos casos (66 poços) e nos demais a utilização é mista, incluindo o uso domiciliar e agropecuário (12,5\%) e domiciliar e comercial (4\%). Nas atividades agropecuárias, a sua utilização está restrita a criações de bovinos, suinos, aves e horticultura, que quase sempre são atividades de pequeno porte, voltadas principalmente para a subsistência. No uso comercial, existem 3 poços localizados em pequeno bar, restaurante e para produção de gelo.

Foi observado que muitos poços rasos permanecem em funcionamento mesmo após a instalação da rede de abastecimento através de poços tubulares nos condomínios, sendo utilizados em jardins e residências quando ocorrem cortes de água relacionados a problemas de manutenção nos poços profundos ou de racionamento durante o período de seca.

Em apenas 4 poços os proprietários informaram a existência de análises de água dos quais 3 haviam sido realizadas entre os anos de 1997 e 1998. Embora não tenha sido possível verificar os resultados dessas análises, os proprietários informaram que elas foram consideradas como águas potáveis. Cerca de $10 \%$ dos usuários de água de poços rasos relataram sintomas tais como diarréia, coceiras no corpo, febre e dores nas articulações, sugestivos de doenças infecciosas e/ou parasitárias características de águas contaminadas.

\section{- Reservação}

Um aspecto fundamental em relação à qualidade das águas que chega aos usuários, e que é muitas vezes negligenciada, é o estado de conservação da reservação. Como as vazões obtidas pelos poços rasos são baixas, as reservações são pequenas, sendo que $79 \%$ delas têm até $1.000 \mathrm{~L}$ e são todas de amianto. Nas demais os volumes vão de $1.500 \mathrm{a}$ $20.000 \mathrm{~L}$, sendo estes últimos são reservatórios do tipo elevada taça ou cilindrico. São utilizados ainda baldes ( 2 poços rasos) e tambores de ferro ( 2 poços rasos), todos estes apresentando condições precárias de armazenamento.

Com relação às condições de conservação destes reservatórios somente em 47 poços foram obtidas informações quanto ao seu estado. Dessa forma, $57,5 \%$ foi considerada boa, sendo realizada a limpeza mensalmente. Uma outra parte, correspondente a $34 \%$, foi considerada em situação regular (limpeza feita semestralmente ou anualmente) e em $8,5 \%$ a situação estava ruim, principalmente devido à inexistência de proteção (tampa) e pela falta de cuidados com a manutenção e limpeza. 


\section{- LIMPEZA E desinfecçÃo}

Um aspecto importante com respeito à qualidade da água em poços rasos é a da sua manutenção, que pode ser feita regularmente pela limpeza e desinfecção do poço. Além de ser de realização simples ela garante uma relativa segurança aos usuários da água. Garcez (1969) recomenda a desinfecção de poços e fontes após o término da construção, antes de usar a água, após reparos nas instalações e sempre que houver suspeita de contaminação. $\mathrm{Na}$ área estudada em apenas 3 casos os proprietários relataram a utilização de água sanitária ou hipoclorito para desinfecção. 


\section{HidRogeoquímicA}

A água na fase líquida é um importante solvente, capaz de dissolver gases, líquidos e sólidos. Ao infiltrar no subsolo sofre diferentes processos físico-químicos que resultam em águas com diferentes composições.

Em terrenos cristalinos sob clima úmido é no manto de intemperismo que a água subterrânea adquire sua composição química inicial. Este manto apresenta condições de circulação e armazenamento da água próprios que o diferenciam significativamente do meio fraturado. Embora no meio fraturado a capacidade de circulação seja mais importante que a de armazenamento, as águas sofrem importantes processos de modificação da sua composição (Bertachini 1987).

A análise dos parâmetros físicos das amostras de água coletadas consistiu nas determinações de temperatura, cor, turbidez e condutividade elétrica. Nas análises químicas foram determinados os ions maiores representados pelos cátions sódio, cálcio, potássio e magnésio, e os ânions cloreto e sulfato. $O$ ion bicarbonato foi calculado a partir da alcalinidade total. Foram realizadas ainda determinações de $\mathrm{pH}$, dureza total, gás carbônico livre, oxigênio consumido e dos compostos de nitrogênio (amônia - nitrito - nitrato). As análises bacteriológicas consistiram nas determinações de coliformes totais e fecais.

Os resultados das análises físico-químicas são apresentados no anexo 3 , e a localização dos pontos de coleta é mostrada na figura 19 (página 72). A amostra P49 foi coletada de poço profundo que explota água do aqüífero poroso (manto de intemperismo), e por isso foi incluída na análise de dados como correspondente a poço raso. A interpretação desses dados permitiu definir as principais características físico-químicas da água subterrânea na região estudada, avaliar a sua qualidade para diversos fins e forneceu indicadores a respeito da evolução da sua composição química.

\section{- Verificaçäo da VAlidade das ANÁlises}

Antes de proceder a análise dos resultados obtidos pelo estudo físico-químico foi calculado o erro referente às determinações feitas em porcentagem (anexo 3). 0 erro foi determinado através do balanço iônico, a partir dos valores em miliequivalentes ( $r$ ) de ânions (cloreto, sulfato, bicarbonato e nitrato) e cátions (sódio, potássio, cálcio e magnésio) que é dado por: Erro $(\%)=r(\Sigma$ cátions $-\Sigma$ ânions $) \times 100$

$r(\Sigma$ cátions $+\Sigma$ ânions $)$ 
Em geral, é admitida como correta uma análise com erro de no máximo $10 \%$. Entretanto é importante considerar que a precisão dos resultados em uma análise depende, entre outros fatores, das concentrações iônicas. Os métodos analíticos padrões são menos precisos para baixas concentrações de ions podendo levar a valores mais elevados de erro, sem necessariamente indicar erros de análise (Feitosa \& Manoel Filho 1997). Em águas de salinidade muito baixa, como é o caso da área de estudo, para os quais os valores de condutividade elétrica estão compreendidos na grande maioria ente 5 e $60 \mu \mathrm{S} / \mathrm{cm}$, o erro admissivel pode ter valores superiores a 10\%. Custódio \& Llamas (1996) consideram que para valores de condutividade elétrica por volta de $50 \mu \mathrm{S} / \mathrm{cm}$ o erro admissível não deve ultrapassar $30 \%$. Apenas 2 amostras apresentaram erros superiores a $30 \%$, o que está associado possivelmente aos elevados valores de sódio e nitrato detectados, sugerindo que tenha havido algum tipo de contaminação da água. Os erros obtidos nas análises foram considerados aceitáveis para a água estudada.

\subsection{PARÂMETROS FísICOS E ORGANOLÉPTICOS}

\section{- Coreturbidez}

A cor das águas está diretamente relacionada à sua capacidade de absorver certas radiações do espectro visivel, e é medida através da comparação com uma solução padrão de Pt-Co. As amostras apresentaram indices médios de cor para poços rasos e profundos respectivamente, de 6 e $9 \mathrm{mg} \mathrm{Pt/L}$, indicando que são águas sem cor aparente.

A turbidez representa a dificuldade da água para transmitir a luz, provocada pela presença de sólidos em suspensão (matéria orgânica e argila). Os valores médios de turbidez das águas de poços profundos e rasos são respectivamente, de 4,16 e 2,91 unidades nefelométricas (NTU) e podem ser considerados comuns para águas subterrâneas, indicando a pequena presença de material fino e coloidal em suspensão.

Apenas 7 amostras (14\%) apresentaram valores de turbidez altos superiores a 5 NTU. Estes valores indicam uma maior quantidade de sólidos em suspensão e especificamente no caso dos poços profundos, podem estar relacionados a problemas construtivos como, por exemplo, o fluxo turbulento devido a filtros com abertura inadequada. 


\section{- temperatura}

A temperatura das águas subterrâneas é, em geral, muito pouco variável e corresponde à média anual da temperatura atmosférica da região (Custódio \& Llamas 1996). As águas na área de estudo pertencem a um sistema de circulação local a intermediário, no qual a profundidade e o grau geotérmico não exercem qualquer influência sobre a sua temperatura. Desta forma observa-se que seus valores seguem a temperatura média da região $\left(23^{\circ} \mathrm{C}\right) \mathrm{com}$ as águas de cacimba e de poços apresentando valores médios respectivamente, de 22,3 e $24,4^{\circ} \mathrm{C}$.

\section{- CONDUTIVIDADE ElÉtRICA}

A condutividade elétrica (CE) expressa a capacidade da água conduzir corrente elétrica, sendo influenciada por diversos fatores, tais como a natureza, concentração e grau de dissociação dos solutos em íons. A água quimicamente pura apresenta CE muito baixa.

Durante as medições de CE em campo várias amostras apresentaram valores de 0 $\mu \mathrm{S} / \mathrm{cm}$ em função da escala de leitura do condutivimetro portátil, que era de $10 \mu \mathrm{S} / \mathrm{cm}$. Como não existe na natureza água totalmente pura, na análise dos dados foram utilizados os valores de CE medidos no laboratório, que apresentam maior precisão.

A CE das águas analisadas é baixa, com $92 \%$ das amostras apresentando valores compreendidos entre 5,64 e $54,1 \mu \mathrm{S} / \mathrm{cm}$. Quatro amostras (8\%) apresentaram valores de 108,2 até $198,3 \mu \mathrm{S} / \mathrm{cm}$. Estes resultados indicam a baixa quantidade de ions dissolvidos nas águas estudadas.

\subsection{PARÂMETROS QUÍMICOS}

- $\mathrm{pH}$

As águas estudadas apresentam caráter ácido, com valores de $\mathrm{pH}$ compreendidos entre 4,5 e 6,5. Somente uma amostra (P73) indicou caráter neutro a levemente alcalino, com pH de 7,7 .

Como a molécula de água $\left(\mathrm{H}_{2} \mathrm{O}\right)$ tem baixa tendência a ionizar-se (baixa constante de dissociação) para formar $\mathrm{OH}^{-}$e $\mathrm{H}^{+}$, o pH da maior parte das águas subterrâneas é controlada pela relação dióxido de carbono dissolvido, carbonatos e bicarbonatos. Para valores de $\mathrm{pH}$ inferiores a 8,3 a quantidade de ion carbonato pode ser considerada nula (Custódio \& Llamas). Por isso, o pH das águas estudadas é controlado pelo $\mathrm{CO}_{2}$ dissolvido e o ín bicarbonato. 
- alcalinidade Total.

A alcalinidade da água é a sua capacidade de neutralização de um ácido. Por isso, embora as águas da região de estudo sejam na grande maioria ácidas ( $\mathrm{pH}$ inferior a 7), podem neutralizar ácidos atuando como solução tampão. A alcalinidade mede os efeitos das concentrações principalmente dos íons $\mathrm{HCO}_{3}{ }^{-}$e $\mathrm{CO}_{3}{ }^{2-}$, já que os de $\mathrm{OH}^{-}, \mathrm{SiO}_{4} \mathrm{H}^{3-}, \mathrm{F}^{-}$, em águas subterrâneas pouco influem (Custódio \& Llamas 1996).

A maioria das amostras ( $96 \%$ ) apresentou baixos valores de alcalinidade compreendidos entre 0,6 e $20,1 \mathrm{mg} / \mathrm{L}$ de $\mathrm{CaCO}_{3}$. As exceções foram as amostras $\mathrm{P} 73\left(127,0 \mathrm{mg} / \mathrm{L}\right.$ de $\left.\mathrm{CaCO}_{3}\right)$ e $\mathrm{C} 71$ ( $52,0 \mathrm{mg} / \mathrm{L}$ de $\mathrm{CaCO}_{3}$ ). Os valores médios de alcalinidade total das águas de poços rasos e poços profundos foram respectivamente, de 7,1 e $9,8 \mathrm{mg} / \mathrm{L}$ de $\mathrm{CaCO}_{3}$.

\section{- DuReza Total}

A dureza de uma água é definida como a soma dos cátions polivalentes, entre os quais os mais comuns são o cálcio e o magnésio, expressos como a quantidade equivalente a carbonato de cálcio. Ela indica a quantidade de sais alcalinos-terrosos contidos na água, sendo também conhecida como a capacidade de precipitar sabão, pois em uma água dura a espuma não se forma enquanto os sais minerais causadores da dureza não houverem sido removidos pela sua combinação com o sabão.

As análises realizadas mostraram que $98 \%$ das águas apresentaram dureza inferior a 70 $\mathrm{mg} / \mathrm{L}$ de $\mathrm{CaCO}_{3}$ e podem ser classificadas como muito brandas, pois seus valores estão compreendidos entre 0,6 e $60,4 \mathrm{mg} / \mathrm{L}$ de $\mathrm{CaCO}_{3}$. Apenas a amostra $\mathrm{P} 73$ pode ser considerada como branda $\left(130,2 \mathrm{mg} / \mathrm{L}\right.$ de $\left.\mathrm{CaCO}_{3}\right)$.

\section{- Calcio}

As litologias da área de estudo são representadas basicamente por quartzitos, metassiltitos e metargilitos, rochas pobres em minerais de cálcio. Por isso, a maioria das amostras do aqüifero fraturado apresentou concentrações de cálcio compreendidas entre 0,24 e 6,40 mg/L, com valor médio de $3,56 \mathrm{mg} / \mathrm{L}$. O único valor que ficou bem acima daqueles observados foi do poço P73 de $42,54 \mathrm{mg} / \mathrm{L}$. Não foi detectada nas análises realizadas a contribuição de cálcio a partir da dissolução de rochas calcárias como mostraram as baixas concentrações do ion, embora existisse essa possibilidade nas amostras representativas do subsistema aqüifero Psamo-Pelito Carbonatado. 
Como o cálcio é um cátion de grande mobilidade, a sua remoção pelo intemperismo químico é muito fácil. Este aspecto fica evidente nas análises de água de poços rasos, que apresentaram valor médio de 2,4 mg/L, com valores compreendidos entre 0,48 e 12,7 mg/L.

\section{- MAgnésio}

Apenas 2 amostras de poços rasos apresentaram concentrações do ion magnésio de $0,33 \mathrm{mg} / \mathrm{L}$ (C67) e 1,77 mg/L (C71). Nas demais não foi detectada a sua presença, refletindo possivelmente o avançado estado de intemperismo químico dos solos da região.

Com relação às águas de poços profundos, em 4 amostras foram detectadas concentrações do ion com valores compreendidos entre 0,05 a $5,79 \mathrm{mg} / \mathrm{L}$. A ausência de magnésio nestas amostras está diretamente relacionado aos minerais que ocorrem nas litologias da região e que são predominantemente argilominerais e quartzo, minerais pobres no íon.

- SÓDIO

Nas águas de poços rasos o valor médio de sódio foi de $2,7 \mathrm{mg} / \mathrm{L}$, sendo que os valores mínimo e máximo foram respectivamente, de 0,1 a $16,0 \mathrm{mg} / \mathrm{L}$. Nos poços profundos a concentração média foi de $0,8 \mathrm{mg} / \mathrm{L}$ com valor máximo de $6,2 \mathrm{mg} / \mathrm{L}$.

O sódio é um íon de grande solubilidade na água, sendo quase todos os seus compostos solúveis, e portanto, dificilmente se precipita. Devido às baixíssimas concentrações nas águas estudadas, a sua principal origem está relacionada às águas de chuva.

\section{- POTÁssio}

As concentrações médias do ín potássio nas águas de poços rasos foram de $0,8 \mathrm{mg} / \mathrm{L}$ e nos poços profundos de $0,5 \mathrm{mg} / \mathrm{L}$. Os valores variaram desde 0,0 até $4,9 \mathrm{mg} / \mathrm{L}$.

As concentrações de potássio observadas nas amostras são inferiores às de sódio. Isto ocorre porque, apesar destes elementos pertencerem ao grupo dos metais alcalinos, seus comportamentos nos processos de solubilização são diferentes. Enquanto o sódio persiste em solução, o potássio é facilmente fixado em minerais de argila. Vários processos podem remover o potássio seletivamente da água, entre eles a troca de bases, a adsorção por argilas e a absorção pelas plantas (Szikszay 1981). A sua tendência em participar do processo de formação de minerais de argila, que são o principal produto de alteração das rochas da região, pode contribuir também para que as concentrações observadas sejam tão baixas. 


\section{- bicarbonato}

As concentrações de bicarbonato das águas analisadas foram calculadas através da relação $\mathrm{HCO}_{3}{ }^{-}(\mathrm{mg} / \mathrm{L})=1,22 \times$ TAC (titulação alcalimétrica completa) (mg/L de $\mathrm{CaCO}_{3}$ ), já que para valores de $\mathrm{pH}$ inferiores a 8,3 o ion carbonato $\left(\mathrm{CO}_{3}{ }^{2-}\right)$ pode ser considerado nulo (Custódio \& Llamas 1996).

A origem do bicarbonato nas águas subterrâneas está principalmente relacionada aos processos que produzem o gás carbônico no solo através da decomposição e oxidação da matéria orgânica, e a respiração das raizes das plantas. A dissolução do $\mathrm{CO}_{2}$ na água forma o ácido carbônico $\left(\mathrm{H}_{2} \mathrm{CO}_{3}{ }^{-}\right)$, que se dissocia em $\mathrm{H}^{+}$e $\mathrm{HCO}_{3}{ }^{-}$. Reações anaeróbias como a redução de sulfato e nitrato podem também produzir $\mathrm{CO}_{2}$, mas geralmente são pouco importantes.

As concentrações do íon bicarbonato em águas do manto de intemperismo ficaram entre 1,46 e $63,44 \mathrm{mg} / \mathrm{L}$, com média de $8,39 \mathrm{mg} / \mathrm{L}$. Nas águas do aqüifero fraturado a média foi mais elevada, de $12,35 \mathrm{mg} / \mathrm{L}$ com valores compreendidos entre 0,73 e $154,94 \mathrm{mg} / \mathrm{L}$ :

O bicarbonato também é produzido pela hidrólise de silicatos e pela dissolução de rochas carbonáticas. Esta contribuição possivelmente é muito pequena nas águas da área de estudo, pois o principal mineral de silicato das rochas é a silica e apenas duas amostras de água indicavam a possibilidade de contribuição de rochas calcárias, que no entanto não foi confirmada.

\section{- Cloreto}

O cloreto nas águas subterrâneas pode ter diversas origens, tais como a dissolução química de rochas igneas (Szikszay 1981), gases vulcânicos ou a atividade antrópica que gera contaminação através de esgotos, aterros sanitários (Menegasse 1991). O ataque químico às rochas é considerado pouco importante pelo fato do cloro ser um elemento escasso na crosta terrestre, exceção que é feita quando se trata de rochas evaporíticas ou algumas rochas igneas e metamórficas que contêm minerais como a sodalita (Custódio \& Llamas 1996).

O íon cloreto apresenta comportamento geoquímico bastante peculiar. Ele não entra significativamente em reações de oxidação ou redução, nem é significativamente adsorvido na superficie de minerais, não forma sais de baixa solubilidade e participa pouco dos processos biológicos (Hem 1985).

Em função dos baixos teores detectados nas águas, com valores compreendidos entre 0,5 e $8,5 \mathrm{mg} / \mathrm{L}$, da ausência de significativas fontes de poluição antrópica, com exceção das fossas, presume-se que a principal fonte de cloreto nas águas estudadas, sejam as águas pluviais. 


\section{- Sulfato}

Existem inúmeras fontes de sulfato nas águas subterrâneas entre os quais podem ser citadas a oxidação de sulfetos, sedimentos clásticos, evaporitos e água da chuva em regiões industriais (Szikszay 1981).

As análises realizadas mostraram que em $72 \%$ não foi detectada a presença de sulfato. Nas demais amostras as concentrações ficaram entre 0,100 e $8,530 \mathrm{mg} / \mathrm{L}$. Os baixos valores encontrados sugerem que na área a contribuição meteórica seja possivelmente a principal responsável pelos teores de sulfato observados. A precipitação atmosférica contém ions sulfato como sais cíclicos e poeira de rochas (Matthess 1982).

\section{- COMPOSTOS DE NITROGENIO}

A presença de amônia pode indicar a ocorrência de compostos de nitrogênio originários de resíduos agrícolas, domésticos e industriais. Quando a contaminação é recente o nitrogênio em geral está presente na forma de nitrogênio orgânico ou amoniacal e se houverem condições aeróbias, o nitrogênio orgânico e a amônia passam, com o decorrer do tempo, às formas de nitrito e nitrato (CETESB 1995).

Das amostras analisadas $76 \%$ apresentaram nitrogênio amoniacal abaixo do limite de detecção $(0,020 \mathrm{mg} / \mathrm{L})$. O valor médio da concentração das amostras no qual foi detectado o ion foi bastante baixo, com valores de $0,212 \mathrm{mg} / \mathrm{L}$ para poços rasos e $0,332 \mathrm{mg} / \mathrm{L}$ para águas de poços profundos.

O amônio é o produto da decomposição orgânica. $\mathrm{O}$ gás amônia $\left(\mathrm{NH}_{3}\right)$ é facilmente solúvel na água e produz hidróxido de amônio $\left(\mathrm{NH}_{4} \mathrm{OH}\right)$, que é parcialmente dissociado fornecendo ions de $\mathrm{NH}_{4}{ }^{+}$e $\circ \mathrm{OH}^{-}$(Szikszay 1981). A formação do nitrogênio amoniacal apresenta baixos valores porque ele marca o primeiro passo na decomposição da matéria orgânica, cuja forma mais estável e final é o nitrato. Além disso, ele se encontra adsorvido nos solos, no qual é utilizado pelas plantas.

Entre os compostos de nitrogênio, os valores mais baixos foram os de nitrito, que em águas de poços rasos forneceram concentração média de $0,006 \mathrm{mg} / \mathrm{L}$ e em poços profundos de $0,004 \mathrm{mg} / \mathrm{L}$. Os nitritos estão presentes apenas em pequenas quantidades, porque são compostos transitórios, que em condições aeróbias logo são convertidos para nitratos.

O nitrato é a fase final e mais estável do nitrogênio, tendo apresentado as maiores concentrações entre os compostos de nitrogênio analisados. A origem do nitrato nas águas subterrâneas é bastante diversificada. Nos solos é muito importante a decomposição da matéria orgânica a partir de plantas que retiram o nitrogênio do ar fixando-o sob a forma de nitrato. 
Fertilizantes nitrogenados, águas de esgoto, fossas, lixo e resíduos industriais são fontes de nitrogênio orgânico e altos teores podem indicar contaminação por essas fontes. As litologias não têm grande influência nos teores de nitrato das águas subterrâneas.

Como a origem do nitrogênio na água está relacionada principalmente aos processos que ocorrem próximos às zonas superficiais dos solos onde a matéria orgânica, as bactérias e os oxigênio são abundantes as concentrações mais elevadas de nitrato foram obtidos em águas de poços rasos com um valor médio de $1,200 \mathrm{mg} / \mathrm{L}$, chegando a um valor máximo de 5,175 $\mathrm{mg} / \mathrm{L}$. Em amostras de poços profundos esses valores ficaram entre 0,040 e $0,690 \mathrm{mg} / \mathrm{L}$, com média de $0,195 \mathrm{mg} / \mathrm{L}$.

$\mathrm{Em} 4$ poços rasos os valores de nitrato foram considerados elevados para as águas naturais da região (em geral inferiores a $1,000 \mathrm{mg} / \mathrm{L}$ ) e ficaram compreendidos entre 1,154 e 5,175 $\mathrm{mg} / \mathrm{L}$. Três destas amostras, através de análises bacteriológicas, indicaram a presença de coliformes fecais, sugerindo que os valores de nitratos destas águas podem indicar contaminação por fossas.

\section{- Gás Carbónico Livre}

As águas de poços profundos apresentaram concentração média de $18,3 \mathrm{mg} / \mathrm{L}$ de $\mathrm{CO}_{2}$ livre, inferior ao valor dos poços rasos, de $23,8 \mathrm{mg} / \mathrm{L}$, já que em águas mais profundas a possibilidade de entrada do $\mathrm{CO}_{2}$ no sistema é mais difícil.

A origem do $\mathrm{CO}_{2}$ dissolvido nas águas subterrâneas está relacionada principalmente às reações químicas e bioquímicas que ocorrem no solo. $\mathrm{O} \mathrm{CO}_{2}$ dissolvido apresenta importante papel no comportamento hidrogeoquímico das águas subterrâneas, pois é através dele que as águas adquirem caráter ácido pela formação de bicarbonatos. Além disso, o pH exerce importante controle sobre as reações químicas em geral.

\section{- OXIGENIO CONSUMIDO}

Este parâmetro fornece os valores de oxigênio consumidos pela microfauna e microflora presentes na matéria orgânica para sua oxidação. Os valores mais elevados de oxigênio consumido foram observados nas águas de cacimba com um valor médio de 1,94 $\mathrm{mg} / \mathrm{L}$ de $\mathrm{KMnO}_{4}$, e valores elevados em duas amostras: 12,7 (C71) e 30,35 (C27) mg/L de $\mathrm{KMnO}_{4}$. O valor médio nos poços profundos foi de $0,50 \mathrm{mg} / \mathrm{L}$ de $\mathrm{KMnO}_{4}$. Estes dados refletem o fato de que as águas mais rasas, do aqüifero freático, estão em contato com o solo no qual existe mais matéria orgânica disponivel e os processos de oxidação são mais intensos. 


\section{- FerRo}

O ferro ocorre sob a forma de íon ferroso $\left(\mathrm{Fe}^{2+}\right)$ e do ín férrico $\left(\mathrm{Fe}^{3+}\right)$. $\mathrm{O}$ ín ferroso pode ocorrer em solução em águas neutras ou levemente ácidas, sendo instável na presença do ar, no qual se oxida para a forma $\mathrm{Fe}^{3+}$ e precipita. Águas de poços freqüentemente contêm $\mathrm{Fe}^{3+}$, porém na forma de suspensão coloidal. Este ferro é solubilizado somente em pH muito baixo, ou transformado em $\mathrm{Fe}^{2+}$ em meio redutor (matéria orgânica) (Szikszay 1993).

Os valores de ferro total observados indicam que, apesar de considerado normalmente como elemento traço, o ferro é bastante comum nas águas da área de estudo. Embora, apresentem concentração média de $0,42 \mathrm{mg} / \mathrm{L}$, em $12 \%$ das amostras os valores foram superiores a $1,00 \mathrm{mg} / \mathrm{L}$. Estes resultados refletem o intemperismo químico bastante intenso atuante na região, pelo qual o ferro e o alumínio são concentrados pelo processo de laterização e podem, sob condições geoquímicas específicas, ceder o ferro para as águas subterrâneas.

\subsection{CLASSIFICAÇÃO dAS ÁGUAS}

De modo geral é possível estabelecer a seguinte relação de predominância iônica para as águas estudadas $(r-$ miliequivalentes por litro):

- ânions: $\mathrm{rHCO}_{3}{ }^{-}>\mathrm{r} \mathrm{Cl}^{-}>\mathrm{rSO}_{4}{ }^{2-}$;

- cátions: $\mathrm{rCa}^{2+}>\mathrm{r} \mathrm{Na}^{+}>\mathrm{rMg}^{2+}$.

Para a classificação das águas foram calculados os valores em percentagem (em meq/L) de cada composto em relação ao total de cátions e ânions, que foram lançados no diagrama triangular de Piper (figura 21). A figura mostra que predominam amplamente as águas bicarbonatadas cálcicas. Subordinadamente, principalmente no manto de intemperismo, ocorrem águas com tendência bicarbonatada sódica e apenas uma amostra foi classificada como cloretada sódica.

\subsection{QUALIDADE dAS ÁGUAS}

\subsubsection{ASPECTOS FísICO-QUímicos}

O principal uso da água na área de estudo é o domiciliar. Em alguns condomínios e chácaras, existe também o uso agrícola. Serão abordados os aspectos relativos a utilização da 


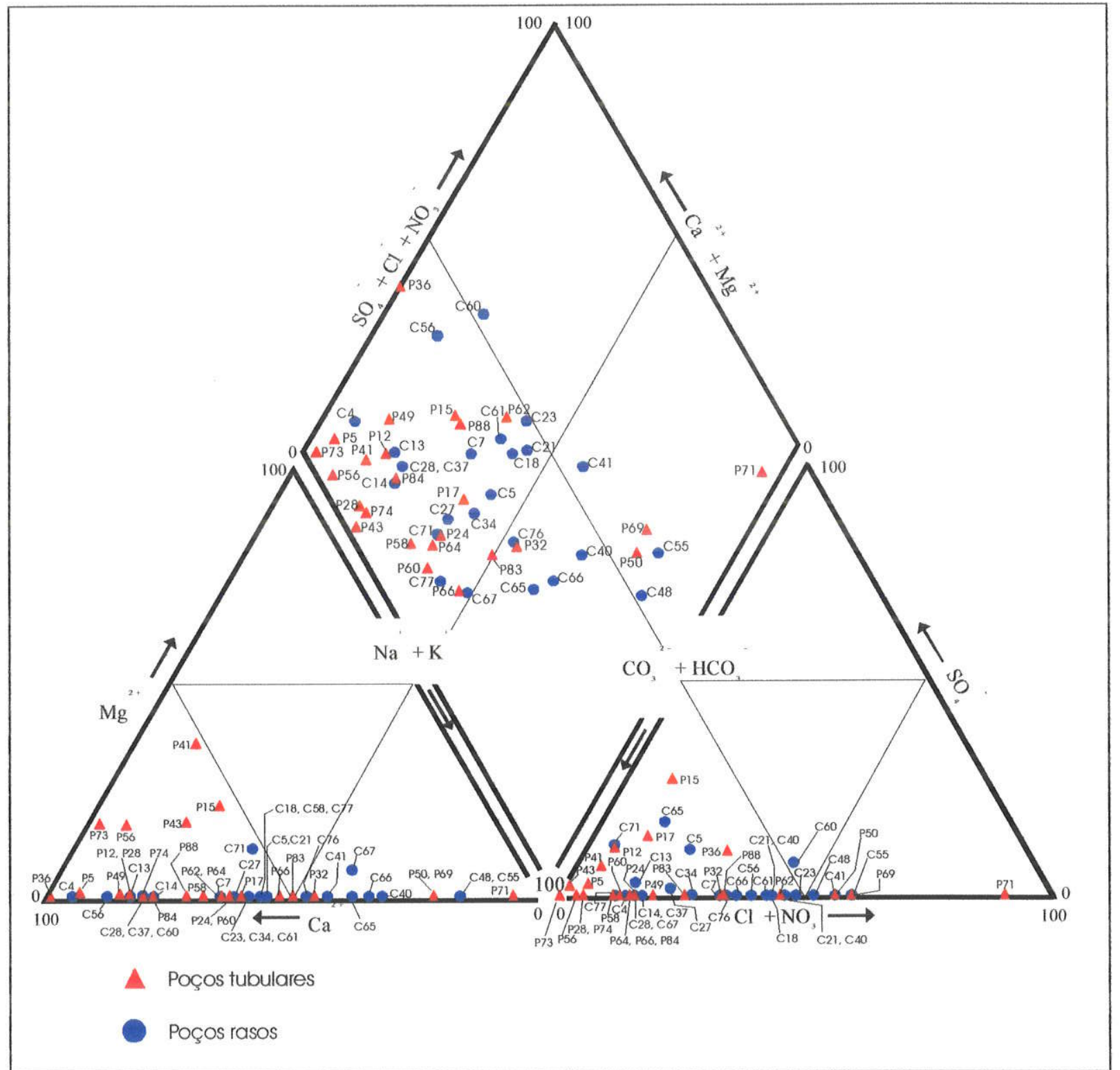

Figura 21. Diagrama de Piper para classificação das águas subterrâneas. 
água para estes fins, pois de acordo com o uso, ela deve atender a certos padrões de qualidade.

\section{- Uso domiciliar}

De forma geral, a água é considerada potável quando pode ser consumida pelo homem sem riscos para sua saúde. Existem diversos padrões de potabilidade na forma de legislação, decretos estaduais e normas internacionais. Neste estudo foram adotadas como referências a portaria 036 do Ministério da Saúde de 1990 e a norma da Organização Mundial de Saúde (CETESB 1990 apud Feitosa \& Manoel Filho 1997) (tabela 20).

Tabela 20. Padrões de potabilidade adotados. (" água entrando no sistema de distribuição)

\begin{tabular}{|c|c|c|c|}
\hline Parâmetros & Unidade & $\begin{array}{c}\text { Portaria } 36 \\
\text { Ministério da } \\
\text { Saúde de 19/01/90 }\end{array}$ & $\begin{array}{c}\text { Organização Mundial } \\
\text { da Saúde (OMS) - } \\
\text { Recomendado }\end{array}$ \\
\hline Cor & $\mathrm{Pt} / \mathrm{L}$ & 15 & 15 \\
\hline Turbidez & UNT & $1^{*}$ & 5 \\
\hline Temperatura & ${ }^{\circ} \mathrm{C}$ & --. & $\cdots$ \\
\hline $\mathrm{pH}$ & $\ldots$ & $6,5-8,5$ & $6,5-8,5$ \\
\hline Dureza total & $\mathrm{mg} / \mathrm{L}$ de $\mathrm{CaCO}_{3}$ & 500 & 500 \\
\hline Cálcio & $\mathrm{mg} / \mathrm{L}$ & $\cdots$ & $-\cdots$ \\
\hline Magnésio & $\mathrm{mg} / \mathrm{L}$ & $\overline{---}$ & $\overline{---}$ \\
\hline Sódio & $\mathrm{mg} / \mathrm{L}$ & 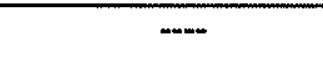 & 200 \\
\hline Alcalinidade & $\mathrm{mg} / \mathrm{L}$ de $\mathrm{CaCO}_{3}$ & $\cdots$ & $m$ \\
\hline Cloreto & $\mathrm{mg} / \mathrm{L}$ & 250 & 250 \\
\hline Sulfato & $\mathrm{mg} / \mathrm{L}$ & 400 & 400 \\
\hline Nitrato & $\mathrm{mg} / \mathrm{L}$ & 10 & 10 \\
\hline Amônia & $\mathrm{mg} / \mathrm{L}$ & $-m$ & $-\cdots+\cdots$ \\
\hline Nitrito & $\mathrm{mg} / \mathrm{L}$ & $-\cdots$ & $\cdots$ \\
\hline Ferro total & $\mathrm{mg} / \mathrm{L}$ & 0,3 & 0,3 \\
\hline Coliformes totais & $\mathrm{NMP} / 100 \mathrm{ml}$ & 0 & 0 \\
\hline Coliformes fecais & $\mathrm{NMP} / 100 \mathrm{ml}$ & 0 & 0 \\
\hline
\end{tabular}

Como as águas estudadas apresentam baixo grau de salinização não foram observadas restrições, de forma geral, em relação aos principais parâmetros químicos analisados quando 
comparados às normas de potabilidade, sendo a única exceção o ferro total. Em relação às demais propriedades foram observados problemas em relação a cor, turbidez e pH.

As normas consideram que a água deve apresentar índice de cor até $15 \mathrm{mg} \mathrm{Pt/L}$ e 15 UNT para turbidez. O valor de 1 UNT considerada como valor máximo permissivel pela portaria 036 não foi levado em conta na presente análise pois ele é utilizado para águas tratadas entrando no sistema de distribuição.

Das análises realizadas 2 amostras de poços rasos (C4 e C27) e 5 de poços profundos (P5, P12, P66, P73, P74) apresentaram indices de cor superiores ao valor permitido, sendo que o valor mais alto foi de 60 (P74). Os resultados de turbidez indicam que 3 amostras de poços rasos $(\mathrm{C} 4, \mathrm{C} 27, \mathrm{C} 66)$ e 6 de poços profundos (P5, P12, P66, P73, P74, P89) possuem valores acima do máximo permitido. A cor e turbidez da água não são por si sós aceitos como indicadores de potabilidade, mas são parâmetros estéticos importantes para o consumo humano e podem muitas vezes indicar contaminação orgânica.

O teor de ferro é de considerável interesse para a qualidade das águas, pois afeta seriamente o seu uso para algumas finalidades domésticas e industriais. Os padrões de potabilidade estabelecem para a água potável um valor máximo de $0,3 \mathrm{mg} / \mathrm{L}$ de ferro total. Em $80 \%$ das amostras analisadas o valor de ferro total ficou acima deste valor. O ferro nas águas da região tem origem natural associada aos processos de laterização com concentração de ferro, que é liberado posteriormente para a água.

Convém observar que os valores máximos permitidos para o ferro nas águas são menores que a de muitos outros ions menores da água, e isso não se deve a razões fisiológicas, já que inclusive o corpo humano requer 5 a 6 miligramas de ferro por dia." $\mathrm{O}$ problema é que o ferro na água causa mancha nas instalações sanitárias e roupas lavadas, incrustações nos filtros de poços e obstrução nas canalizações pela formação de ferrugem e pela proliferação de bactérias (JOHNSON 1966).

Os valores de $\mathrm{pH}$ devem ficar dentro do intervalo de 6,5 a 8,5 . Entretanto, $96 \%$ das amostras analisadas apresentaram valores inferiores a $6,5 . \mathrm{O} \mathrm{pH}$ fora da faixa recomendada pode alterar o sabor da água contribuindo para a corrosão do sistema de distribuição de água, ocorrendo com isso, uma possivel extração de elementos como ferro, cobre, chumbo, e zinco (CETESB 1995).

As águas analisadas, em termos práticos, podem ser consideradas adequadas ao consumo humano. Existem apenas restrições quanto a algumas propriedades organolépticas, embora elas não comprometam diretamente a sua utilização. 
- USo Agricola

$\mathrm{Na}$ agricultura a utilização da água subterrânea exige o conhecimento da sua composição, das características do solo e do tipo de cultura a ser irrigada. A análise da Razão de Absorção de Sódio (SAR) permite avaliar de forma geral as possibilidades de uso da água para irrigação. O SAR prediz razoavelmente o grau que a água de irrigação tende a entrar nas reações de troca catiônica. Altos valores de SAR (superiores a 18) implicam em risco de substituição pelo sódio do cálcio e magnésio adsorvidos no solo, o que é danoso à sua estrutura (Hem 1985).

Para a classificação das águas subterrâneas estudadas foi utilizado o gráfico proposto pelo Laboratório de Salinidade do Departamento de Água dos EUA (figura 22). Estas águas de acordo com a figura são de salinidade fraquíssima $\left(\mathrm{C}_{0}\right)$ que podem ser utilizadas sem restrição para a irrigação, e fracamente sódicas $\left(S_{1}\right)$, indicando a possibilidade de utilização em quase todos os tipos de solos. A limitação em relação ao uso do gráfico do SAR foi que a sua escala de condutividade elétrica se inicia apenas a partir de $100 \mu \mathrm{S} / \mathrm{cm}$ e $92 \%$ das amostras analisadas apresentavam valores inferiores a este valor. Entretanto, em função do baixo grau de salinização e dos valores de SAR inferiores a 3,01, estas amostras podem ser classificadas da mesma forma que as outras.

\subsubsection{ASPECTO BACTERIOLÓGICO}

As bactérias vêm sendo utilizadas a bastante tempo como indicadoras de qualidade de água e da associação com outras doenças de transmissão hidrica. A facilidade de crescimento e de deteç̧ão tornam as bactérias os traçadores microbiológicos mais comumente utilizados no reconhecimento do potencial de transmissão de doenças por microorganismos (Keswick et al. 1982). Os critérios bacteriológicos para abastecimento de água limitam o número de coliformes totais e fecais a menos de um coliforme por $100 \mathrm{ml}$.

As bactérias coliformes são excretadas em grande quantidade através das fezes humanas e de outros animais homotérmicos. O número de bactérias por grama de fezes apresenta valores entre 100 milhões e 1 bilhão (Garcez 1969). Os coliformes fecais representam um subgrupo das bactérias coliformes e são utilizados como indicadores da contaminação fecal. Embora estejam presentes nas fezes de animais, não são organismos patogênicos, mas indicadores de contaminação por excretas que podem conter outros microorganismos como, por exemplo, as bactérias Salmonella (febre tifóide, paratifóide, salmonelose), Shigella (desinteria bacilar) e o vírus da Hepatite A (hepatite infecciosa). Modernamente considera-se que os coliformes fecais são mais significativos do que os 


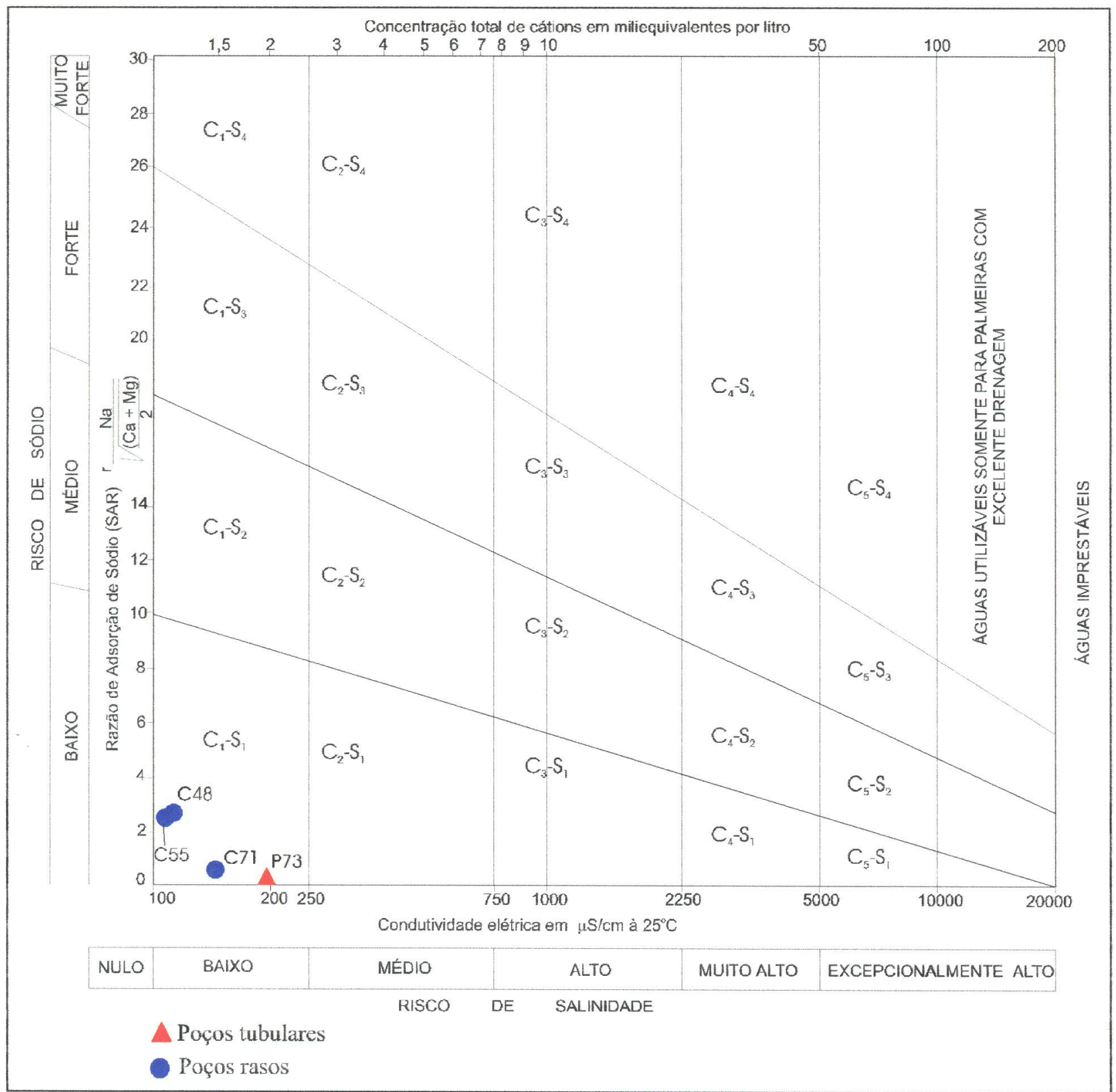

Figura 22. Diagrama SAR para classificação de águas para irrigação (US Salinity Laboratory Staff 1957).

coliformes totais na avaliação da contaminação fecal, principalmente nos casos de contaminação recente (Vignoli Filho 1980). Os coliformes totais têm sido utilizados como indicadores das condições de higiene (Martins et al. 1991 apud Melo 1995).

Durante o processo de infiltração dos efluentes no terreno os microorganismos contidos na matéria fecal são eliminados total ou parcialmente pelos fenômenos de filtração e adsorção, que dependem fundamentalmente das características do meio não saturado com relação a sua litologia e profundidade das águas subterrâneas (Melo 1995). 
As análises bacteriológicas em águas de poços tubulares revelaram que em nenhum poço foi detectada a presença de coliformes fecais. Estes resultados indicam que o aqüífero fraturado está melhor protegido da contaminação, principalmente aquela originária da disposição de efluentes domésticos no terreno, que é a principal fonte de contaminação das águas na área de estudo. Em apenas 2 poços (P15 e P83) o NMP (número mais provável) de coliformes totais foi de $8 / 100 \mathrm{ml}$. A presença de coliformes totais detectados podem ser solucionados através da cloração e desinfecção dos poços, já que pelas observações de campo não existiam problemas de proximidade com fossas.

Das 25 análises de águas de poços rasos em apenas um poço (C4) não foi detectada a presença de coliformes. Esta amostra foi coletada de um poço raso bem construído, apresentando tampa de cimento e laje sanitária adequadas, revestimento com manilhas em toda sua extensão e fossa bem afastada.

Nos demais poços foram detectadas a presença de coliformes totais (14 amostras) e coliformes totais e fecais (10 amostras). Os valores de contagem de coliformes totais em amostras com indicação de contaminação bacteriológica variaram de 13 até mais de 1600/100 $\mathrm{ml}$, e os valores de coliformes fecais ficaram entre 2 e $300 / 100 \mathrm{ml}$.

Entre os poços no qual foi observada apenas a presença de coliformes totais os principais problemas observados nos poços rasos no campo foram:

- Tampa ausente ou em estado precário;

- Boca do poço sem altura mínima;

- Poço sem revestimento ou parcialmente revestido;

- Utilização do sarrilho;

- Laje sanitária ausente.

Estes aspectos construtivos das obras restringem as condições de higiene para a captação de água e criam condições para a proliferação de bactérias.

Em 6 poços rasos as observações de campo indicaram a possibilidade de contaminação fecal devido à proximidade de fossas, que no entanto não foi detectada pelas análises bacteriológicas. Em 5 destes casos os poços estão localizados em regiões onde o nivel freático está a mais de $14 \mathrm{~m}$ de profundidade, o que pode indicar a boa capacidade de autodepuração da zona não saturada antes do efluente doméstico atingir o aqüifero.

Em 10 poços rasos foi detectada a presença simultânea de coliformes totais e fecais. Além das captações apresentarem problemas construtivos similares àqueles descritos anteriormente, existia o problema da proximidade fossa-poço, com distâncias variando entre $2 \mathrm{e}$ $25 \mathrm{~m}$, de acordo com as observações de campo. Mesmo em poços dentro dessa distância, mas 
com fossas localizadas em cotas topográficas inferiores foram detectados coliformes fecais, 0 que pode ser estar relacionado às características do meio poroso (solo) que na região apresenta condutividade hidráulica média (equivalente a areia fina). No poço C48 foi observado a maior contagem de coliformes fecais com $300 / 100 \mathrm{ml}$ e concentração de nitrato de $5,1 \mathrm{mg} / \mathrm{L}$, consideravelmente alto para a região.

\subsection{ASPECTOS DA EVOLUÇÃO DA COMPOSIÇÃO QUÍMICA}

Apesar de ter sido realizada apenas uma etapa de amostragem das águas subterrâneas, com base nos dados obtidos foi possivel obter algumas evidências de processos que influenciam a sua composição química.

A água de precipitação pluviométrica apresenta uma determinada composição química inicial e ao atingir o solo e infiltrar sofre modificações físico-químicas resultantes das características mineralógicas, texturais, litológicas e químicas do manto de intemperismo. Ao atravessar o solo a água de chuva pode dissolver os constituintes minerais. Entretanto, devido às características dos solos da região este processo de dissolução ocorre de forma bem restrita na área estudada.

Os solos da região são caracterizados por terem sofrido intensa lixiviação que resultou em baixíssimas concentrações de elementos como cálcio, magnésio, potássio e sódio, e na formação de compostos insolúveis de elementos como silicio, alumínio e ferro. Por isso são observados baixos valores de condutividade elétrica nas águas de poços rasos, indicando o baixo nivel de ions dissolvidos, e que se reflete diretamente nas baixas concentrações dos íons cáicio e magnésio. Apesar de não se dispor de análises químicas de água de chuva, é possível supor que em termos de íons maiores elas sejam composicionalmente semelhantes.

Entretanto, importantes processos modificadores da composição química da água acontecem no manto de intemperismo e resultam no aumento das concentrações de bicarbonato e nitrato.

O bicarbonato é gerado principalmente através da dissolução do $\mathrm{CO}_{2}$, produzido no solo pela decomposição da matéria orgânica e respiração das plantas. Este processo ocorre em 3 etapas (Hem 1985):

(1) $\mathrm{CO}_{2(\mathrm{~g})}+\mathrm{H}_{2} \mathrm{O}_{(\mathrm{l})}=\mathrm{H}_{2} \mathrm{CO}_{3(\mathrm{aq})}$

(2) $\mathrm{H}_{2} \mathrm{CO}_{3(\mathrm{aq})}=\mathrm{H}^{+}+\mathrm{HCO}_{3}^{-}$

(3) $\mathrm{HCO}_{3}{ }^{-}=\mathrm{H}^{+}+\mathrm{CO}_{3}{ }^{2-}$ 
Para valores de $\mathrm{pH}$ inferiores a 8,3 a terceira etapa é muito pouco importante. Por isso, a segunda etapa representa possivelmente o grande controle dos baixos pHs nas águas estudadas, através da produção de $\mathrm{H}^{+}$e formação de bicarbonato, que é o ânion predominante das águas dos aqüiferos porosos e fraturados.

O nitrato também é produzido no solo, principalmente pela decomposição da matéria orgânica e pelo metabolismo de bactérias. Os baixos teores dos outros compostos de nitrogênio se deve à tendência da amônia em ser fixada irreversivelmente no solo e do nitrito em se alterar rapidamente para nitrato sob condições oxidantes.

Os solos da região apresentam mineralogicamente quartzo, caulinita, gibbsita, materiais amorfos e óxido de ferro. Os hidróxidos e óxidos de ferro são pouco solúveis em condições naturais. Em águas de $\mathrm{pH}$ baixo o ferro ferroso ocorre em condições redutoras (matéria orgânica) e o ferro férrico na forma de suspensão coloidal (Szikszay 1993). O ferro pode também ser liberado pela alteração de metassedimentos que inclui a oxidação de argilominerais (cloritas e ilitas) liberando $\mathrm{Fe}^{2+}$ (Campos \& Freitas Silva 1998). Por isso, são observadas concentrações relativamente elevadas, acima de $0,3 \mathrm{mg} / \mathrm{L}$, de ferro total nas águas analisadas.

Os minerais amorfos e argilas têm considerável capacidade de troca de cátions e podem dessa forma alterar as razões entre cátions na água subterrânea. As concentrações dos íons sódio, cálcio e magnésio nas águas são fortemente influenciadas pela troca iônica (Custódio \& Llamas 1996). O potássio apresenta concentrações inferiores ao sódio que reflete a sua tendência de ser fixado irreversivelmente à estrutura dos argilominerais. Entretanto, como predomina a caulinita como principal produto do intemperismo na região, a capacidade de troca iônica é significativamente baixa. Matthess (1982) apresenta a seguinte ordem decrescente de capacidade de troca iônica para argilominerais: vermiculita, montmorillonita, ilita e caulinita.

Apesar disso, é possivel observar que argilominerais apresentam alguma importância na composição quimica das águas estudadas. O comportamento dos metais alcalinos na área de estudo foi avaliado pelo indice de troca de bases ou ions (itb) (Schoeller 1962):

$$
i t b=\frac{r \mathrm{Cl}^{-}-r\left(\mathrm{Na}^{+}+\mathrm{Cl}^{-}\right)}{\mathrm{r} \mathrm{Cl}^{-}}
$$

Os resultados obtidos mostram que na grande maioria das amostras de água do manto de intemperismo $(52 \%)$ o itb é negativo, com valores compreendidos entre $-2,567$ e $-0,163$, indicando que o meio geológico fornece metais alcalinos. Possivelmente o sódio está sendo cedido para as águas e íons como magnésio e cálcio, estão sendo retidos pelos argilominerais. Essa é uma tendência dos processos de troca catiônica nos sistemas naturais em que ions divalentes são extraídos da solução e substituidos por íns monovalentes (Matthess 1982). 
Os baixos valores de itb entre $-0,100$ e 0,100 , observados em 8 amostras (32\%), indicam que existe equilíbrio entre a água e o terreno. Foram obtidos em 4 amostras valores de itb positivos e maiores que 0,100 , que indicam que o meio geológico está fornecendo para a água metais alcalinos-terrosos e retirando metais alcalinos.

Embora a troca catiônica ocorra de forma restrita pelas características naturais da região, no qual predominam argilominerais de baixa capacidade de troca iônica, ela pode alterar significativamente a composição das águas estudadas que apresentam concentrações muito baixas de ions. A presença de águas bicarbonatadas sódicas, nas quais o sódio é o cátion dominante, possivelmente está relacionado a este processo.

No aqüifero fraturado existe um contato mais restrito entre rocha e água que restringe os processos de hidrólise de minerais e cessão de íns para a água. Além disso, os minerais predominantes nas litologias da área de estudo são argilominerais (principalmente ilita) e quartzo que são pobres em ions como cálcio, sódio e magnésio. Por isso, não existem processos significativos de mineralização das águas, resultando em baixas concentrações de íns dissolvidos e de condutividade elétrica.

Em $72 \%$ das amostras dos poços profundos os valores de itb calculados são negativos, indicando que metais alcalinos estão entrando em solução possivelmente pela substituição com alcalinos-terrosos. Em 5 amostras o itb ficou entre $-0,100$ e 0,100 , sugerindo equilíbrio entre $o$ meio e a água, e em 2 amostras o itb foi positivo e maior que 0,100 , mostrando a tendência do cálcio e magnésio serem liberados para a água e do sódio ser fixado.

As águas estudadas são, portanto, pouco mineralizadas pois o manto de intemperismo intensamente lixiviado e 0 meio fraturado são formados basicamente por quartzo e argilominerais como caulinita e ilita, minerais pobres em elementos como cálcio, magnésio e sódio. Os principais processos modificadores da composição química das águas ocorrem no solo pela formação do bicarbonato e nitrato, e a troca catiônica realizada pelos argilominerais. Os elementos dissolvidos nas águas da região provêm, principalmente, das águas de chuva e do solo. Parisot (1983) descreve mecanismos semelhantes em aqüifero sedimentar aluvial e terciário intensamente lixiviado em São Paulo. 


\section{Conclusões}

A água subterrânea, especialmente a partir da década de 90 , se tornou importante alternativa de abastecimento para uma significativa parcela da população da bacia do ribeirão Sobradinho. Esta demanda tem aumentado significativamente em função do processo de parcelamento do solo, que resultou na formação dos condomínios. De acordo com os dados levantados, pelo menos 22.500 pessoas dependem exclusivamente do recurso hídrico subterrâneo na área de estudo.

A área estudada é representada geologicamente por metassedimentos de idade proterozóica deformados durante o Ciclo Brasiliano, que encontram-se recobertos por espesso manto de intemperismo. As unidades litoestratigráficas metassedimentares são correlacionadas aos grupos Paranoá e Canastra.

Foram individualizados dentro do contexto hidrogeológico local, os domínios aqüiferos Poroso e Fraturado. O Domínio Fraturado foi classificado em dois sistemas denominados de Paranoá e Canastra. O Sistema Paranoá foi subdividido em quatro subsistemas aqüiferos: Metarritmito Arenoso, Quartzito, Metarritmito Argiloso e Psamo-Pelito Carbonatado. Como não foram cadastrados na área poços pertencentes ao Sistema Canastra, e em função da sua ocorrência restrita, ele foi considerado indiviso. Devido ao forte controle litológico e estratigráfico observado nos aqüiferos fraturados, a classificação proposta seguiu a nomenclatura das principais unidades geológicas.

O Domínio Poroso está associado, na região, ao manto de intemperismo (solo e saprolito), sendo representado por aqüiferos livres, de grande continuidade lateral. Os aqüiferos associados aos aluviões são restritos e pouco espessos, não apresentando importância no quadro hidrogeológico local. A espessura e permeabilidade do manto de intemperismo apresentam grande controle em função do substrato geológico. Nas unidades com grande contribuição psamítica, as espessuras são relativamente pequenas e a permeabilidade elevada. Nas unidades com caráter pelítico, o manto de intemperismo é muito espesso, chegando a mais de $100 \mathrm{~m}$, e a permeabilidade, especialmente dos saprolitos, é controlado pelos variados graus de laterização. Como predominam na região as seqüências metarritmicas, na qual se alternam pelitos e psamitos, as variações nas características hidráulicas do regolito são muito grandes.

O Domínio Poroso é explotado na região através de poços rasos, principalmente nas regiões central e sul da área de estudo, que apresentam ocupação de caráter predominante rural. O manto de intemperismo também desempenha importante função na manutenção da 
perenidade das drenagens da região, na proteção ao aqüifero à contaminação antrópica e na alimentação do aqüifero fraturado.

No Domínio Fraturado, o Subsistema Aqüiffero Quartzito, em função da sua ampla distribuição e elevada média de vazões $\left(8,7 \mathrm{~m}^{3} / \mathrm{h}\right)$, apresenta grande importância na região. Os subsistemas aqüíferos Metarritmito Arenoso e Psamo-Pelito Carbonatado ocorrem em porções restritas da área de estudo, apresentando bom potencial hidrogeológico, evidenciado pelas elevadas vazões médias de 26,7 e $15,7 \mathrm{~m}^{3} / \mathrm{h}$, respectivamente. O Subsistema Metarritmito Argiloso, apesar da sua ampla distribuição, apresenta pequena vocação hídrica (vazão média de $4,6 \mathrm{~m}^{3} / \mathrm{h}$ ), evidenciada pela incidência de poços secos.

As condições de circulação da água no sistema fraturado da região estão condicionadas ao padrão de fraturamento das rochas. As principais fraturas produtoras nos poços ocorrem próximas à superficie, concentrando-se em profundidades até $100 \mathrm{~m}$. Foram identificados na área de estudo 4 familias de fraturas, que por sua gênese essencialmente extensional, apresentam condições favoráveis para a formação de bons aqüíferos que são: N5W, N30E, N-S e N75-85W. Embora não tenha sido possivel relacionar a produtividade dos poços aos lineamentos fotointerpretados, estudos geofísicos em áreas selecionadas poderão auxiliar na identificação destas familias de fraturas em subsuperficie. É recomendável que sejam aprofundados os estudos sobre a tectônica pós-proterozóica no DF, que poderão fornecer novos subsídios para a prospecção nos aqüíferos fraturados.

O tipo litológico também exerce importante controle sobre a produtividade dos poços da região. O comportamento rúptil dos quartzitos favorece o desenvolvimento de uma razoável densidade de fraturas abertas, quando comparada aos metassiltitos, metargilitos e filitos, resultando em poços mais produtivos.

A recarga dos aqüiferos da região é função da precipitação pluviométrica, que na região estudada apresenta média anual de $1442,5 \mathrm{~mm}$. Cerca de $28 \%$ do volume precipitado participa efetivamente da recarga dos aqüíferos. O conhecimento disponivel entretanto, não permite calcular com uma margem de segurança as reservas dos aqüiferos estudados em função da heterogeneidade dos meios fraturado e poroso, que apresenta significativas variações laterais e verticais de espessura e permeabilidade.

O principal uso da água subterrânea na região é o domiciliar, representado pelos grandes condomínios e chácaras. As águas dos aqüiferos poroso e fraturado são de boa qualidade físico-química, não apresentando restrições quanto ao seu uso. Apresentam baixíssimo grau de mineralização em função da associação entre manto de intemperismo 
extremamente lixiviado e litologias que contêm minerais pobres em íons maiores. As águas são classificadas como bicarbonatadas cálcicas e subordinadamente, bicarbonatadas sódicas.

A contaminação bacteriológica observada em amostras de água do manto de intemperismo está relacionada às deficiências construtivas dos poços rasos e a proximidade entre fossa e poço. A boa qualidade bacteriológica da água de poços profundos indica que o aqüífero fraturado está mais protegido da influência das fossas, a principal fonte de contaminação das águas subterrâneas da região.

Embora tenham sido identificados elevados niveis de contaminação bacteriológica, a utilização de poços rasos, pelo menos na região rural, não pode ser considerada inviável, desde que a obra de captação seja bem construída, apresentando uma distância mínima de $30 \mathrm{~m}$ da fossa. Entretanto, são comuns poços mal construídos apresentando diversos problemas, tais como revestimento interno parcial, ausência de laje de proteção sanitária e tampa sem oferecer vedação. Muitas vezes estes problemas refletem a falta de orientação técnica durante a construção do poço raso.

Em relação aos profundos, observa-se na região uma grande proliferação de pequenas empresas de perfuração que realizam a obra sem conhecimento técnico qualificado, que é evidenciado pela baixa qualidade técnica dos relatórios disponiveis. Este fato também fica claro pelas avaliações das condições de proteção do aqüifero, sendo observadas deficiências dos poços em diversos aspectos, como as ausências de cimentação entre os tubos de revestimento interno e externo, de laje de proteção sanitária e de critérios de desativação e abandono dos poços. Predomina também, por parte dos proprietários, uma visão imediatista da explotação da água subterrânea, em que não existe uma preocupação em relação à qualidade técnica da construção e manutenção do poço.

A preocupação em relação à gestão dos recursos hídricos no DF está expressa através da Lei $n^{\circ} 512$ de 28/7/93, que dispõe sobre a Política de Recursos Hídricos no Distrito Federal institui o Sistema de Gerenciamento de Recursos Hídricos - SIGRH. Entretanto, o controle sobre o uso e concessão da água subterrânea não estão ainda definidos claramente. Por isso, tem ocorrido um crescimento descontrolado do número de poços na região, sem levar em conta as caracteristicas hidrogeológicas dos aqüiferos e a sustentabilidade do recurso hídrico. $\mathrm{A}$ área de recarga na região noroeste da área de estudo, por exemplo, é intensamente explotada através de poços profundos e encontra-se bastante ocupada e impermeabilizada, afetando as condições de realimentação dos aqüiferos. A área de ocorrência do Subsistema Aqüifero Metarritmito Argiloso está sendo intensamente explotada na região norte da bacia e têm surgido muitos problemas de poços secos e desativados por queda de vazão. Falta ainda também, uma 
legislação específica para a água subterrânea que regulamente o processo de outorga e fiscalização, de modo a exigir dos perfuradores de poços uma melhor qualificação técnica para elaboração da obra de captação. A etapa inicial para o gerenciamento do recurso hídrico subterrâneo deverá partir da elaboração de um cadastro completo dos poços da região. Os dados disponiveis no banco de dados criado para este estudo representam um significativo avanço neste sentido. 


\section{REFERÊNCIAS BILBLIOGRÁFICAS}

ABNT - ASSOCIAÇÃO BRASILEIRA DE NORMAS TÉCNICAS (1990) Projeto de poço para captação de água subterrânea - NB 588. Rio de Janeiro, ABNT.

ABNT - ASSOCIAÇÃO BRASILEIRA DE NORMAS TÉCNICAS (1990) Construção e captação de água subterrânea - NB 1290. Rio de Janeiro, ABNT.

ALMEIDA, F.F.M. (1967) Origem e evolução da Plataforma Brasileira. Rio de Janeiro, DNPM/DGM. (Boletim n $\left.{ }^{\circ} 241\right)$.

ALMEIDA, F.F.M. \& HASUI, Y., coords. (1984) O pré-Cambriano do Brasil. São Paulo, Edgar Blücher. $378 \mathrm{p}$.

ALMEIDA, F.F.M.; BRITO NEVES, B.B.; FUCK, R.A. (1977) Províncias estruturais brasileiras. In: SIMPÓSIO DE GEOLOGIA DO NORDESTE, 8., Campina Grande, 1977. Atas. Recife, SBG/NNE, p. 363-391.

APHA - AMERICAN PUBLIC HEALTH ASSOCIATION (1985) Standard methods for the examination of water and wastewater. 16. ed. Washington, APHA. 1 v.

ARAÚJO FILHO, J.O. \& FARIA, A. (1992) Características estruturais de propagação do empurrão Canastra sobre o Paranoá no Evento Brasiliano no Distrito Federal. In: CONGRESSO BRASILEIRO DE GEOLOGIA, 37., São Paulo, 1992. Anais. São Paulo, SBG, p. 319-320.

BARBOSA, O. (1955) Guia das excursões do $9^{\circ}$ Congresso Brasileiro de Geologia. Noticiário, v. 3, p. 3-5.

BARBOSA, O., coord. (1961) Geologia econômica e aplicada no Distrito Federal. Rio de Janeiro, DNPM /PROSPEC.

BARBOSA, O., coord. (1963) Geologia econômica aplicada a uma parte do Planalto Central Brasileiro. Rio de Janeiro, DNPM/PROSPEC. 
BARBOSA, O., coord. (1970) Projeto Goiânia. Relatório preliminar. Petrópolis, DNPM/PROSPEC.

BARBOSA, O.; BAPTISTA, M.B.; DYER, R.C.; BRAUN, O.P.G.; COTTA, J.C. (1969) Geologia e inventário dos recursos minerais do Projeto Brasilia. Rio de Janeiro, DNPM/PROSPEC.

BARROS, J.G.C., coord. (1987) Inventário hidrogeológico do Distrito Federal. Brasília, CAESB. 4 v.

BARROS, J.G.C. (1994) Caracterização geológica e hidrogeológica do Distrito Federal. In: NOVAES PINTO, M., coord. Cerrado: caracterização ocupação e perspectivas. 2. ed. Brasilia, UnB. p. 265-283.

BELCHER, J. (1954) O relatório sobre a nova capital - Relatório Belcher. Rio de Janeiro, DASP.

BERTACHINI, A.C. (1987) Estudo das caracteristicas hidrogeológicas dos terrenos cristalinos sob clima úmido, na região de Jundiaí. em São Paulo. São Paulo, 105 p. (Dissertação - Mestrado) - Instituto de Geociências, Universidade de São Paulo.

BLANCO, S.B. (1995) Aspectos de geologia de engenharia da escavação do Metrô de Brasília - trecho Asa Sul. Brasília, 92 p. (Dissertação - Mestrado) - Instituto de Geociências, Universidade de Brasília.

BRAUN, O.P.G. (1968) Contribuição à estratigrafia do Grupo Bambuí. In: CONGRESSO BRASILEIRO DE GEOLOGIA, 22., Belo Horizonte, 1981. Anais. Belo Horizonte, SBG, p. 155-166.

CAESB - COMPANHIA DE ÁGUA E ESGOTOS DE BRASILIA (1998) Informações básicas sobre os sistemas de abastecimento de água no Distrito Federal. Brasilia, CAESB.

CAMPOS, J.E.G \& FREITAS-SILVA, F.H. (1998) Hidrogeologia do Distrito Federal. In: Inventário Hidrogeológico e dos Recursos Hídricos Superficiais do Distrito Federal. Brasília, IEMAUUnB/SEMATEC. 
CAVALCANTE, I.N. (1990) Estudo hidrogeológico de terreno cristalino com manto de intemperismo: área piloto de Atibaia (SP). São Paulo, 123 p. (Dissertação - Mestrado) Instituto de Geociências, Universidade de São Paulo.

CAVALCANTE, I.N. \& REBOUÇAS, A.C. (1990) Caracterização hidrogeológica de terrenos cristalinos com manto de alteração. Revista Água Subterrânea, n. 13, p. 9-20.

CAVALCANTI, M.A.M.P. (1996) Impacto dos sistemas de saneamento "in situ" nas águas subterrâneas no bairro de Piratininga - município de Niterói (RJ). São Paulo 95 p. (Dissertação - Mestrado) - Instituto de Geociências, Universidade de São Paulo.

CETESB - COMPANHIA DE TECNOLOGIA DE SANEAMENTO AMBIENTAL (1988) Guia de coleta e preservação de amostras de água. São Paulo, CETESB. 150 p.

CETESB - COMPANHIA DE TECNOLOGIA DE SANEAMENTO AMBIENTAL (1995) Relatório de qualidade das águas subterrâneas do estado de São Paulo: 1994. São Paulo, CETESB. (Série Relatórios)

CICCO, V.; FARIA, A.J.; ARCOVA, F.C.S; SHIMOMICHI, P.Y. (1985) Determinação do balanço hídrico com emprego de bacia hidrográfica experimental em mata secundária. In: SIMPÓSIO BRASILEIRO DE HIDROLOGIA E RECURSOS HIDRICOS, 6., São Paulo, 1985. Anais. São Paulo, ABRH, v. 3, p. 234-245.

CLOUD, P. \& DARDENNE, M.A. (1973) Proterozoic age of the Bambui Group in Brazil. Geological Society American Bulletin, v. 84, n. 5, p. 1673-1676.

CODEPLAN - COMPANHIA DE DESENVOLVIMENTO DO PLANALTO (1984) Atlas do Distrito Federal. Brasilia, GDF. 78 p.

COIMBRA, A.R.S.R. (1987) Balanço hídrico preliminar do Distrito Federal. In: BARROS, J.G.C., coord. (1987) Inventário hidrogeológico do Distrito Federal. Brasília, CAESB, v. 1, p. 50-78.

CONGRESSO BRASILEIRO DE GEOLOGIA, 24., Brasilia, 1970. Roteiro das Excursões (Boletim Especial 2). Brasília, SBG, 1970. p. 138-163. 
COSTA, W.D. (1965) Análise dos fatores que influenciam na hidrogeologia do cristalino. Revista Agua Subterrânea, v. 4, p. 14-46.

COSTA, W.D. (1975) Estudo hidrogeológico preliminar das cidades do Gama, Taguatinga. Ceilândia e Sobradinho no Distrito Federal. Brasília, CNTGE/CAESB. v. 1.

COSTA, W.D. (1980) A hidrogeologia do cristalino à luz da mecânica das rochas. In: CONGRESSO BRASILEIRO DE ÁGUAS SUBTERRÂNEAS, 1., Recife, 1980. Anais. Recife, ABAS, p. 375-383.

COSTA, W.D. (1986) Análise dos fatores que atuam no aqüifero fissural: área piloto dos estados da Paraíba e Rio Grande do Norte. São Paulo, 205 p. (Tese - Doutorado) - Instituto de Geociências, Universidade de São Paulo.

COSTA, L.A.M. \& ANGEIRAS, A.G. (1971) Geosynclinal evolution in the epi-Baykalian platform of central Brazil. Geologische Rundschau, v. 60, n. 2, p. 1024-1050.

CUSTÓDIO, E. \& LLAMAS, M.R., eds. (1996) Hidrologia subterránea. 2. ed. Barcelona, Omega. v. 1.

DARDENNE, M.A. (1978a) Zonação tectônica na borda ocidental do Cráton do São Francisco. In: CONGRESSO BRASILEIRO DE GEOLOGIA, 30., Recife, 1978. Anais. Recife, SBG, v. 1, p. 299-308.

DARDENNE, M.A. (1978b) Síntese sobre a estratigrafia do Grupo Bambui no Brasil central. In: CONGRESSO BRASILEIRO DE GEOLOGIA, 30., Recife, 1978. Anais. Recife, SBG, v. 2, p. 597-610.

DARDENNE, M.A. (1979) Les mineralisations de plomb. zinc. fluor du Proterozique Superieur dans le Brésil Central. Avec une mise au point sur la chronologie du Precambrien brésilien. Paris, 251 p. (Tese - Doutorado) - Université Paris VI.

DARDENNE, M.A. \& CAMPOS NETO, M.C. (1976) Geologia da região de Lagamar - MG. In: CONGRESSO BRASILEIRO DE GEOLOGIA, 29., Ouro Preto, 1976. Resumos. Ouro Preto, SBG, p. 17. 
DARDENNE, M.A. \& FARIA, A. (1985) Estratigrafia do Grupo Paranoá na região de Alto Paraíso de Goiás - GO. In: SIMPÓSIO DE GEOLGOIA DO CENTRO-OESTE, 2., Goiânia 1985. Anais. Goiânia, SBG/NCO, p. 65-71.

DAVIS, S.N. \& DEWIEST, R.J.M. (1966) Hydrogeology. EUA, John Wiley \& Sons, Inc. 463 p.

DOMENICO, P.A. \& SCHWARTZ, F.W. (1990) Physical and chemical hydrogeology. Singapura, John Wiley \& Sons, Inc. 824 p.

DUARTE, U. \& KANEHISA, M.S. (1986) Captações rasas em zonas urbanas. In: CONGRESSO BRASILEIRO DE ÁGUAS SUBTERRÂNEAS, 4., Brasilia, 1986. Anais. Brasilia, ABAS, v. 1, p. 237-250.

EMBRAPA - EMPRESA BRASILEIRA DE PESQUISA AGROPECUÁRIA (1978) Levantamento e reconhecimento dos solos do Distrito Federal. Rio de Janeiro, SNCLS. (Boletim Técnico $n^{\circ} 53$ ).

EMBRAPA - EMPRESA BRASILEIRA DE PESQUISA AGROPECUÁRIA (1983) Levantamento do reconhecimento de baixa intensidade dos solos e aptidão agrícola das terras de parte da região geoeconômica de Brasilia. Rio de Janeiro, SNCLS. (Boletim de Pesquisa $n^{\circ} 24$ ).

ENGEVIX. (1994) Revisão e atualização das diretrizes gerais de uso da Área de Proteção Ambiental da bacia do rio São Bartolomeu. Proposta de rezoneamento - Relatório técnico preliminar. Brasilia, Convênio IEMA/SEMATEC. v. 1.

FARIA, A. (1988) Mapa geológico do Distrito Federal. Brasilia, DNPM/UnB. (Escala $1: 100.000)$.

FARIA, A. (1989) O Grupo Paranoá no Distrito Federal. In: SIMPÓSIO DE GEOLOGIA DO NÚCLEO DE MINAS GERAIS, 5., SIMPÓSIO DE GEOLOGIA DO NÚCLEO DE BRASILIA, 1., Belo Horizonte, 1989. Anais. Belo Horizonte, SBG, p. 262-265. (Boletim n 10).

FARIA, A. (1995) Estratigrafia e sistemas deposicionais do Grupo Paranoá nas áreas de Cristalina. Distrito Federal e São João D'Aliança - Alto Paraiso de Goiás. Brasília, 220 p. (Tese - Doutorado) - Instituto de Geociências, Universidade de Brasília. 
FCTH - FUNDAÇÃO CENTRO TECNOLÓGICO DE HIDRÁULICA (1988) Projeto. perfuração e operação de poços profundos. São Paulo, FCTH. 249 p.

FEITOSA, F.A.C. \& MANOEL FILHO, J., coords. (1997) Hidrogeologia: conceitos e aplicações. Fortaleza, CPRM/LABHID/UFPE. $412 \mathrm{p}$.

FERNANDES, A.J. (1997) Tectônica cenozóica na porção média da bacia do rio Piracicaba e sua aplicação à hidrogeologia. São Paulo, 244 p. (Tese - Doutorado) - Instituto de Geociências, Universidade de Brasilia.

FREEZE, R.A. \& CHERRY, J.A. (1979) Groundwater. New Jersey, Prentice Hall. 604 p.

FREITAS-SILVA, F.H. \& DARDENNE, M.A. (1994) Proposta de subdivisão estratigráfica formal para o Grupo Canastra no oeste de Minas Gerais e leste de Goiás. In: SIMPÓSIO DE GEOLOGIA DO CENTRO-OESTE, 4., Brasilia, 1994. Anais. Brasilia, SBG-DF/CO, p. 14165.

FREITAS-SILVA, F.H. \& CAMPOS, J.E.G. (1998) Geologia do Distrito Federal. In: Inventário Hidrogeológico e dos Recursos Hídricos Superficiais do Distrito Federal. Brasília, IEMA/UnB/SEMATEC. (Relatório Técnico Parcial $n^{\circ} 1$ ).

FREITAS-SILVA, F.H.; CAMPOS, J.E.G.; BARROS, J.G.C. (1994) Arcabouço estrutural do Parque Nacional de Brasilia. In: SIMPÓSIO DE GEOLOGIA DO CENTRO-OESTE, 4., Brasilia, 1994. Boletim de Resumos. Brasilia, SBG. p. 167-169.

FUCK, R.A. (1990) Dobramentos neoproterozóicos da margem ocidental do Cráton do São Francisco: revisão. In: CONGRESSO BRASILEIRO DE GEOLOGIA, 36., Natal, 1990. Boletim de Resumos. Natal, SBG, p.288-289.

FUCK, R.A. (1994) A Faixa Brasília e a compartimentação tectônica na Província Tocantins. In: SIMPÓSIO DE GEOLOGIA DO CENTRO-OESTE, 4., Brasilia, 1994. Anais. Brasilia, SBG, p. 184-187.

FUCK, R.A. \& MARINI, O.J. (1979) Projeto São Félix - geologia da folha Córrego São Bento. Brasilia, UnB/Eletronorte. 
FUCK, R.A. \& MARINI, O.J. (1981) O Grupo Araxá e unidades homotaxiais. In: SIMPÓSIO DO CRATON DO SÃO FRANCISCO E SUAS FAIXAS MARGINAIS, 1., Salvador, 1979. Anais. Salvador, SBG/NBA-SE, SGM/Secretaria de Minas e Energia, p. 118-130.

FUCK, R.A.; JARDIM DE SÁ, E.F.; PIMENTEL, M.M.; DARDENNE, M.A.; PEDROSA SOARES, A.C. (1992) As faixas de dobramentos marginais do Cráton do São Francisco: sintese dos conhecimentos. p. 161-185. In: Reunião preparatória do II Simpósio do Cráton do São Francisco, Salvador. Dominguez, J.M.L. \& MISI, A., eds. (1993) Q C Cráton do São Francisco. Salvador, SBG/SGM/CNPQ. 213 p.

FUCK, R.A.; PIMENTEL, M.M.; D'EL-REY SILVA, L.J.H. (1994) Compartimentação tectônica na porção oriental da Província Tocantins. In: CONGRESSO BRASILEIRO DE GEOLOGIA, 38., Balneário Camboriú, 1994. Anais. Balneário Camboriú, SBG, p. 215-216.

GARCEZ, L.N. (1969) Elementos de engenharia hidráulica e sanitária. 2. ed. São Paulo, Edgard Blucher. $356 \mathrm{p}$.

GDF - GOVERNO DO DISTRITO FEDERAL (1996) Parcelamentos do solo em processo de regularização. Região Administrativa (RA) V - Sobradinho. Brasília, GDF. v. 1. (Série Temática, Documento 4).

GONÇALVES, R.L.F. (1978) Critérios fotogeológicos para locação de poços em rochas cristalinas de Minas Gerais. In: CONGRESSO BRASILEIRO DE GEOLOGIA, 30., Recife, 1978. Anais. Recife, SBG, v. 6, p. 2934-2942.

GREHS, S.A. (1968) A conceituação de "fratura geológica" aplicada a caracterização geotécnica. In: CONGRESSO BRASILEIRO DE GEOLOGIA, 22., Belo Horizonte, 1968. Anais. Belo Horizonte, SBG, p. 255-258.

HARIDASAN, M. (1994). Solos. In: NOVAES PINTO, M., coord. Cerrado: caracterização. ocupação e perspectivas. 2. ed. Brasilia, UnB. p. 321-344.

HAUSMAN, A. (1980) Avaliação qualitativa de aqüiferos fissurados. In: CONGRESSO BRASILEIRO DE ÁGUAS SUBTERRÂNEAS, 1., Recife, 1980. Anais. Recife, ABAS, p. 537544. 
HEILBRON, M.H.; VALERIANO, C.M.; ZIMBRES, E.; CHRISPIM, S.J.; SIMÕES, A.; SOUZA, M.A.T. (1987) O contato basal do Grupo Canastra entre Itaú de Minas e Carmo do Rio Claro, MG. In: SIMPÓSIO DE GEOLOGIA DE MINAS GERAIS, 4., Belo Horizonte, 1987. Anais. Belo Horizonte, SBG/MG, bol. 6, p. 179-198.

HEM, J.D. (1985) Study and interpretation of the chemical characteristics of natural waters. U.S. Geological Survey Water Supply Paper, 2254, 263 p.

HENRIKSEN, H. (1995) Relation between topography and well yield in boreholes in crystalline rocks, Sogn og Fjordane, Norway. Ground Water, v. 33, n. 4, p. 635-643.

IBGE - INSTITUTO BRASILEIRO DE GEOGRAFIA E ESTATÍSTICA (1991) Censo demográfico de 1991 - versão preliminar. Rio de Janeiro, IBGE.

IPDF - INSTITUTO DE PLANEJAMENTO TERRITORIAL E URBANO DO DISTRITO FEDERAL (1996) Plano Diretor de Ordenamento Territorial do Distrito Federal (PDOT). Brasilia, IPDF.

ITONAGA, L.C.H. \& EID, N.J. (1995) A regionalização hidrológica e uma abordagem multitemporal da evolução do uso do solo no Distrito Federal. In: SIMPÓSIO BRASILEIRO DE RECURSOS HIDRICOS, 11., SIMPÓSIO DE HIDRÁULICA E RECURSOS HIDRICOS DOS PAISES DE LINGUA OFICIAL PORTUGUESA, 2., Recife, 1995. Anais. Recife, ABRH, p. 7698.

JOHNSON, INC. (1966) Ground water and wells. Saint Paul, UOP Jonhson Division Inc. 482 p.

KESWICK, B.H.; WANG, D.; GERBA, C.P. (1982) The use of microorganisms as groundwater tracers: a review. Ground Water, v. 20, n. 2, p. 142-149.

KING, L.C. (1956) A geomorfologia do Brasil Central. Revista Brasileira de Geografia, v. 18, n. 2 , p. 147-265.

KNOPMAN, D.S. \& HOLLYDAY, E.F. (1993) Variation in specific capacity in fractured rocks, Pennsylvania. Ground Water, v. 31, n. 1, p. 135-145. 
KRONBERG, B.I.; FYFE, W.S.; LEONARDOS, O.H.; SANTOS, A.M. (1979) The chemistry of some brazilian soils: element mobility during intense weathering. Chemical Geology, v. 24, p. 211-229.

KROTHE, N.C. \& BERGERON, M.P. (1981) The relationship between fracture traces and joints in a Tertiary Basin, southwest Montana. Ground Water, v. 19, n. 2, p. 138-143.

LADEIRA, E.A. \& SALOMÃO, E.P. (1970) Excursão pela margem norte e oriental do Lago Paranoá. In: CONGRESSO BRASILEIRO DE GEOLOGIA, 14., Brasilia, 1970. Roteiro das Excursões. Brasilia, SBG, p. 153-163. (Boletim especial $n^{\circ} 2$ ).

MABEE, S.B.; HARDCASTLE, K.C.; WISE, D.U. (1994) A method of collecting and analyzing lineaments for regional-scale fractured-bedrock aquifer studies. Ground Water, v. 32, n. 6, p. 884-894.

MARTINS, E.S.; CARDOSO, F.B.F.; GASPAR, J.C. (1994) Dados prelimares da geologia de perfis de intemperismo em cortes do Metrô, Águas Claras, DF. In: SIMPÓSIO DE GEOLOGIA DO CENTRO-OESTE, 4., Brasília, 1994. Resumos Expandidos. Brasilia, SBG, p. 202-205.

MATTHESS, G. (1982) The properties of groundwater. New York, John Wiley \& Sons. 406 p.

MATTOS, A. \& VILLELA, S.M. (1987) Evapotranspiração real média espacial em uma bacia hidrográfica. In: SIMPÓSIO BRASILEIRO DE HIDROLOGIA E RECURSOS HÍDRICOS, 4., Fortaleza, 1987. Anais. Fortaleza, ABRH, v. 2, p. 204-221.

MELO, J.G. de (1995) Impactos do dessenvolvimento urbano nas águas subterrâneas de Natal/RN. São Paulo, 196 p. (Tese - Doutorado) - Instituto de Geociências, Universidade de São Paulo.

MENDONÇA, A.F.; LIMA, A.; BARROS, J.G.C.; CORTOPASSI JÚNIOR, R.; CORTOPASSI, R. (1994) Critérios geológicos e geotécnicos para execução de sondagens na área do Distrito Federal. In: CONGRESSO BRASILEIRO DE MECÂNICA DOS SOLOS E ENGENHARIA DE FUNDAÇÕES, 10., Foz do Iguaçu, 1994. Anais. Foz do lguaçu, ABMS, v. 2, p. 389-395. 
MENEGASSE, L.N. (1991) Estudo hidrogeológico das rochas metassedimentares do Grupo São Roque a NW da Grande São Paulo - critérios para locação de poços. São Paulo, 104 p. (Dissertação - Mestrado) - Instituto de Geociências, Universidade de São Paulo.

MORTARI, D. (1994) Caracterização geotécnica e análise do processo evolutivo das erosões no Distrito Federal. Brasilia, 210 p. (Dissertação - Mestrado) - Faculdade de Tecnologia, Universidade de Brasília.

NETO, C.B. \& RICALDI, A.E.M. (1993) Riscos de poluição de águas subterrâneas através de fontes pontuais de captação - poços profundos. In: CONGRESSO BRASILEIRO DE ENGENHARIA SANITARIA E AMBIENTAL, 17., Natal, 1993. Anais. Natal, ABES, v. 2, tomo IV, p. 351-361.

NOGAMI, P.S. (1967) Poços. Tradução do Manual Técnico $n^{\circ}$ 5-297 do Departamento do Exército dos EUA. Rio de Janeiro. 262p.

NOVAES PINTO, M. (1986a) Superfícies de aplainamento na bacia do rio São Bartolomeu Distrito Federal. Revista Brasileira de Geografia, v. 48, n. 3, p. 237-257.

NOVAES PINTO, M. (1986b) Caracterização morfológica do curso superior do rio São Bartolomeu - Distrito Federal. Revista Brasileira de Geografia, v. 48, n. 4, p. 377-397.

NOVAES PINTO, M. (1987) Superficies de aplainamento do Distrito Federal. Revista Brasileira de Geografia, v. 49, n. 2, p. 9-26.

NOVAES PINTO, M. (1994a) Caracterização geomorfológica do Distrito Federal. In: NOVAES PINTO, M., coord. Cerrado: caracterização ocupação e perspectivas. 2. ed. Brasilia, UnB. p. 285-320.

NOVAES PINTO, M. (1994b) Paisagens de Cerrado. In: NOVAES PINTO, M., coord. Cerrado: caracterização, ocupação e perspectivas. 2. ed. Brasilia, UnB. p. 511-542.

OLIVEIRA, M.M.A. (1967) Contribuição à geologia da parte sul da Bacia do São Francisco e áreas adjacentes. Rio de Janeiro, Petrobrás/DEPIN/CENPES. v. 1, p. 71-105. (Coletânea de relatórios de exploração). 
OLIVEIRA, J.F. de; MACIEL, G.F.; OLIVEIRA, A.P. (1996) Cálculo de precipitação média de uma bacia utilizando métodos geoestatísticos. In: SIMPÓSIO DE RECURSOS HIDRICOS DO NORDESTE, 3., Salvador, 1996. Anais. Salvador, ABRH, p. 1-8.

PACHECO, A. (1984) Análise das características técnicas e da legislação para uso e proteção das águas subterrâneas em meio urbano - município de São Paulo. São Paulo, 174 p. (Tese - Doutorado) - Instituto de Geociências, Universidade de São Paulo.

PARISOT, E.H. (1983) As águas subterrâneas no centro-oeste do municipio de São Paulo Características hidrogeológicas e químicas. São Paulo, 93 p. (Dissertação - Mestrado) Instituto de Geociências, Universidade de São Paulo.

PENTEADO, M.M. (1976) Tipos de concreções ferruginosas nos compartimentos geomorfológicos do Planalto de Brasilia. Notícia Geomorfológica, v. 16, p. 39-53.

PIUCl, J. (1986) Problemática dos poços escavados no Brasil (uma reflexão crítica). São Paulo, DAEE.

PLANIDRO (1970) Água subterrânea para fins de abastecimento de água e irrigação no DF. Brasília, PLANIDRO. (Relatório n. 6).

RADAMBRASIL (1982) Folha SD. 23 - Brasília. Rio de Janeiro, Ministério de Minas e Energia - Secretaria Geral. v. 19. (Levantamentos de recursos naturais).

RAMOS, J.R.A. (1956) Folha geológica da Nova Capital. Rio de Janeiro, DNPM/DGM. p. 5558. (Relatório Anual do Diretor)

ROMANO, O. \& ROSAS, J.G.C. (1970) Água subterrânea para fins de abastecimento de água e irrigação no Distrito Federal. In: CONGRESSO BRASILEIRO DE GEOLOGIA, 24., Brasília, 1970. Anais. Brasilia, SBG, p. 313-333.

SANDER, P.; MIROR, T.B.; CHESLEY, M.M. (1997) Ground-water exploration based on lineament analysis and reprodutibility tests. Ground Water, v. 35, n. 5 , p. 888-894.

SANTOS, J.P., coord. (1989) Estudos de hidrogeologia. In: Plano diretor de abastecimento de água, de esgotamento sanitário e controle da poluição das águas do Distrito Federal Zona rural. Brasilia, CAESB/CNEC. 184 p. 
SCHOELLER, H. (1962) Les eaux souterraines. Paris, Mason. 642 p.

SETZER, J. (1964) Fraturas observadas em fotografias aéreas e sua significação hidrogeológica. Boletim da Sociedade Brasileira de Geologia, v. 13, n. 1, p. 55-60.

SHAW, E.M. (1994) Hidrology in practice. 3. ed. Londres, Chapman \& Hall. 569 p.

SILVA, A.B. da (1994) Estudo hidrogeológico do municipio de Belo Horizonte - MG. In: CONGRESSO BRASILEIRO DE ÁGUAS SUBTERRÂNEAS, 8., Recife, 1994. Anais. Recife, ABAS, p. 481-490.

SIQUEIRA, L. (1963) Contribuição da geologia à pesquisa de água subterrânea no cristalino. Aqua Subterrânea, n. 9, p. 1-29.

SODRÉ, M.C.B.; MELLLO, J.C.; LIMA JÚNIOR, G.C. (1986) Locação de poços tubulares em rochas cristalinas, associadas a ocorrência de veios de quartzo. In: CONGRESSO BRASILEIRO DE ÁGUAS SUBTERRÂNEAS, 8., Brasilia, 1986. Anais. Brasilia, ABAS, p. 404-412.

SZIKSZAY, M. (1981) Hidrogeoquímica das fontes de Áquas da Prata, estado de São Paulo: origem, classificação e caracterização. São Paulo, 2 v. (Tese - Livre-Docência) - Instituto de Geociências, Universidade de São Paulo.

SZIKSZAY, M. (1993) Geoquímica das Águas. Boletim IG-USP, Série Didática n. 5, 166 p.

TEIXEIRA, N.A. \& DANNI, J.C.M. (1978) Contribuição à estratigrafia do Grupo Araxá na região de Passos, MG. In: CONGRESSO BRASILEIRO DE GEOLOGIA, 30., Recife, 1978. Anais. Recife, SBG, v.3, p. 700-711.

THORNTHWAITE, C.W. (1948) An approach toward a rational classification of climate. Geographical Review, v. 38, n. 1, p. 55-94.

TUCCI, C.E.M., org. (1993) Hidrologia: ciência e aplicação. 1. ed. Porto Alegre, Ed. da Universidade/edUSP/ABRH. v. 4.

U.S. SALINITY LABORATORY STAFF. (1954) Diagnosis and improvement of saline and alkali soils. U.S. Department of Agriculture Handbook 60, 160 p. 
VALERIANO, C.M.; SIMÕES, L.S.A.; GODOY, A.M. (1989) Compartimentação tectônica da porção meridional das faixas Uruaçu e Brasilia, SW de Minas Gerais: dados preliminares. In: SIMPÓSIO DE GEOLOGIA DE MINAS GERAIS, 5., Belo Horizonte, 1989. Anais. Belo Horizonte, SBG/MG, bol. 10, p. 238-242.

VIGNOLI FILHO, O. (1980) A contaminação de águas subterrâneas em regiões semi-áridas e úmidas e seu relacionamento com indicadores biológicos usuais. In: CONGRESSO BRASILEIRO DE ÁGUAS SUBTERRÂNEAS, 1., Recife, 1980. Anais. Recife, ABAS, p. 303310.

VILLELA, S.M. \& MATTOS, A. (1975) Hidrologia aplicada. São Paulo, McGraw-Hill. 245 p.

YIN, Z.Y. \& BROOK, G.A. (1992) The topographic approach to locating high-yield wells in crystalline rocks: does it work. Ground Water, v. 30, n. 1, p. 96-102. 
ANEXO 1

FICHAS DE CADASTRO 
Ficha de CADAstro de Poco Raso

\begin{tabular}{|c|c|}
\hline DATA: & N'DO POCOO RASO: \\
\hline \multicolumn{2}{|l|}{ NOME DO PROPRIETÁRIO: } \\
\hline \multicolumn{2}{|l|}{ ENDEREÇO: } \\
\hline COORDENADAS UTM: & KME. \\
\hline $\begin{array}{l}\text { POSIÇÃO TOPOGRÁFICA: (A) CHAPADA (B)ENCOSTA } \\
\text { (C) VALE }\end{array}$ & COTA TOPOGRÁFICA: \\
\hline
\end{tabular}

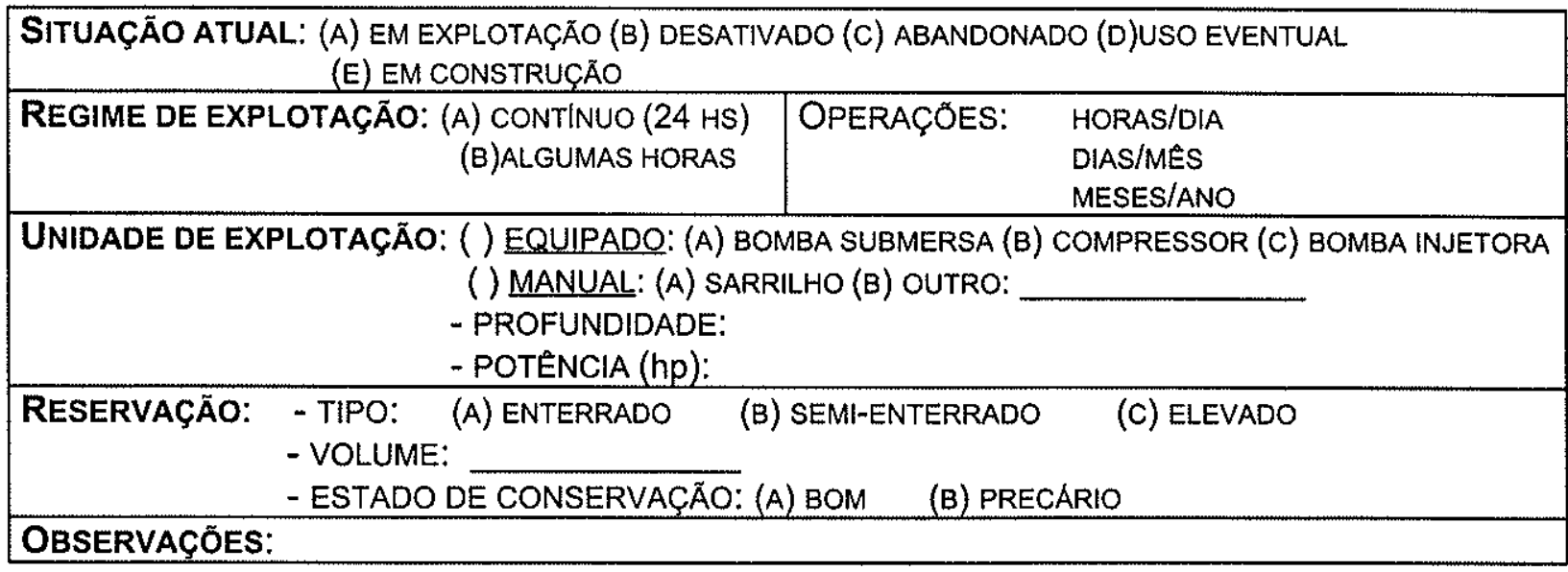

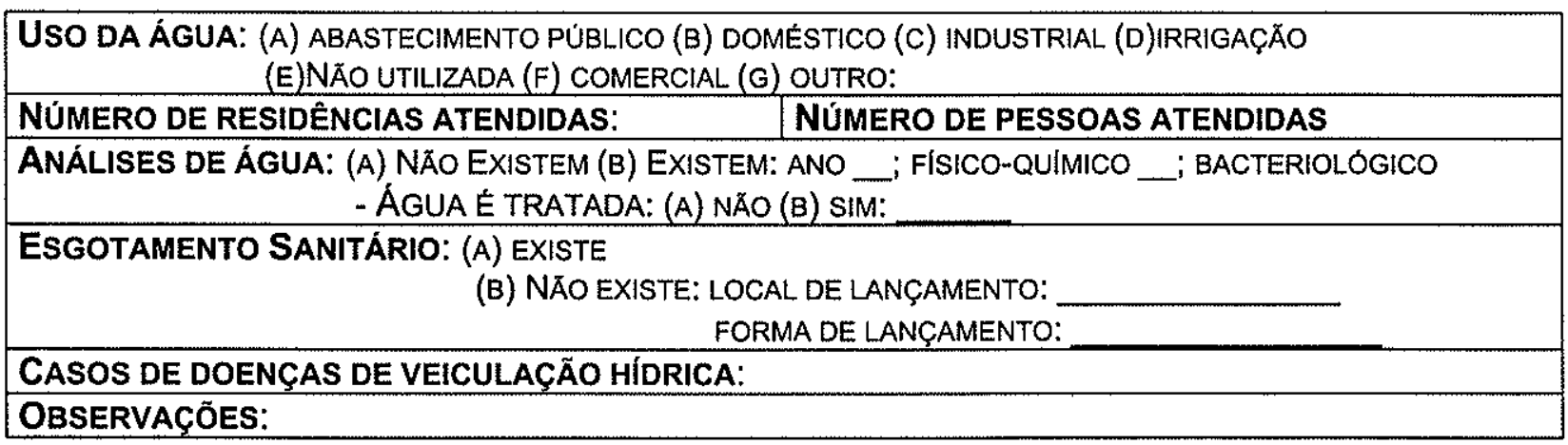

LOCAÇÃO EM RELAÇÃo A POSSIVEIS FONTES DE CONTAMINAÇÃO/POLUIÇÃo (fossas, esterqueira, postos de serviço, acumulação de lixo, ...):

CIMENTAÇÃO: (A) AUSENTE (B) PRESENTE - OBSERVAÇÓES

ACABAMENTO: (A) ABERTO (B) LAGEADO (C) CIMENTADO (D) TIJOLO (E) OUTROS:

PROTEÇÃO SUPERIOR:

- LAJE dE PROTEÇÃo: (A) CORRETA (B) AUSENTE (C) MAL CONSTRUIDA:

- TAMPA: (A) CORRETA (B) AUSENTE (B) DESLOCADA (C) MAL FIXADA (D) OUTRO:

OBSERVAÇõES:

\begin{tabular}{|l|l|}
\hline PROFUNDIDADE DO POÇO: & NÍVEL DE ÁGUA NO POÇO: \\
\hline DIÂMETRO: & \\
\hline OBSERVAÇÕES: & \\
\hline
\end{tabular}




\section{FICHA DE CADASTRO DE POCOO PROFUndo}

DATA:

NOME DO PROPRIETÁRIO:

ENDERECO:

\begin{tabular}{|c|c|}
\hline EMPRESA PERFURADORA: & \\
\hline ANO DE CONSTRUÇÃO: & \\
\hline COORDENADAS UTM: & $\mathrm{KME}_{;}$ \\
\hline $\begin{array}{l}\text { POSIÇÃO TOPOGRÁFICA: (A) CHAPADA (B)ENCOSTA } \\
\text { (C) VALE }\end{array}$ & COTA TOPOGRÁFICA: \\
\hline
\end{tabular}

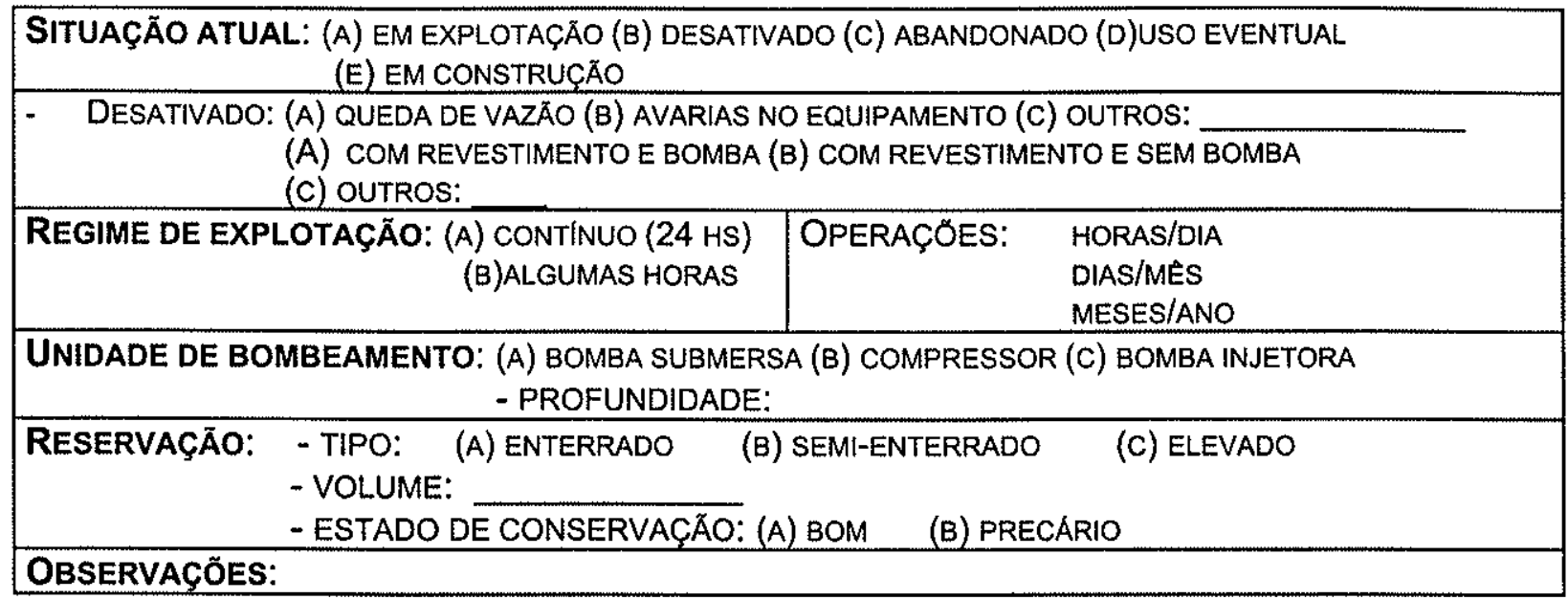

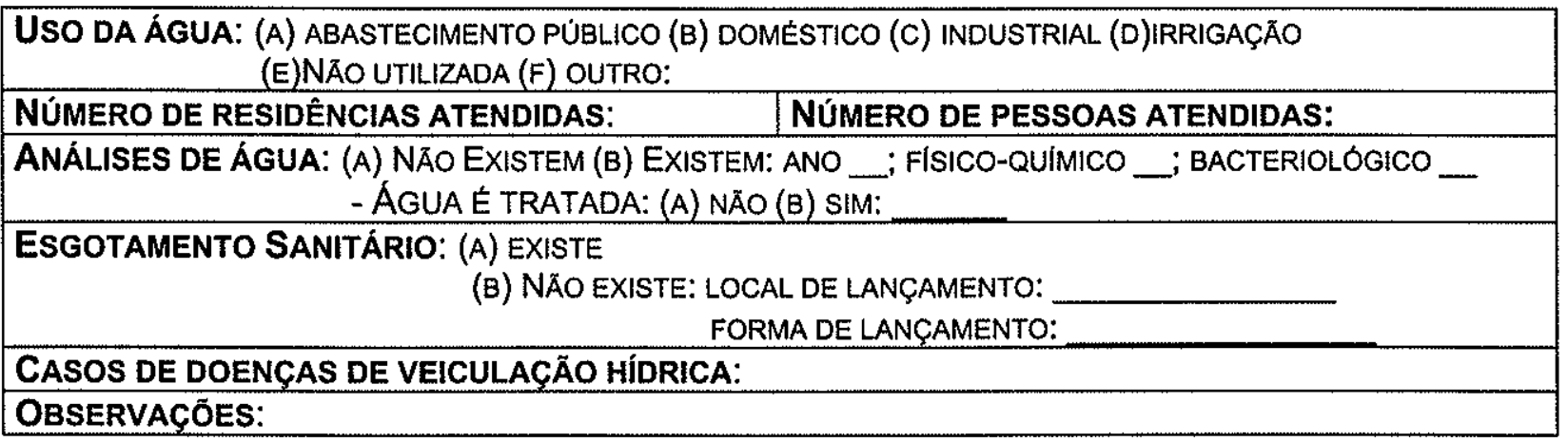

LOCAÇÃO EM RELAÇÃo A POSSÍVEIS FONTES DE CONTAMINAÇÃO/POLUIÇÃO (fossas, esterqueira, postos de serviço, acumulação de lixo, ..):

CIMENTAÇÃO: (A) AUSENTE (B) PRESENTE

$$
\text { - OBSERVACOOES }
$$

\section{PROTEÇÃO SUPERIOR:}

- TUBO DE REVESTIMENTO INTERNO (saliência sobre a laje, altura mínima deve ser de $50 \mathrm{~cm}$ ):

- LAJE DE PROTEÇÃO: (A) CORRETA (B) AUSENTE (C) MAL CONSTRUIDA:

- TAMPA: (A) CORRETA (B) AUSENTE (B) DESLOCADA (C) MAL FIXADA

MANUTENÇÃO DO POÇO: (A) PREVENTIVA (B) CORRETIVA

OBSERVAÇÕES: 


\section{ANEXO 2}

BANCO DE DADOS DAS OBRAS DE CAPTAÇÃO DE ÁGUA SUBTERRÂNEA (EM DISQUETE) 
ANEXO 3

RESULTADOS DAS ANÁLISES FISICO-QUÍMICAS E BACTERIOLÓGICAS DAS ÁGUAS 


\begin{tabular}{|c|c|c|c|c|c|c|c|c|c|c|c|c|}
\hline ParâmetrosıPoço raso & C4 & C5 & C7 & C13 & C14 & C18 & C21 & C23 & C27 & C28 & C34 & C37 \\
\hline $\operatorname{Cor}(\mathrm{Pt} / \mathrm{L})$ & 20 & 2 & 10 & 5 & 6 & 8 & 10 & 3 & 25 & 3 & 4 & 6 \\
\hline Turbidez (UNT) & 11,10 & 0,16 & 3,13 & 0,63 & $\overline{1,91}$ & 2,52 & 4,13 & 1,38 & 16,80 & 1,48 & 0,64 & $\overline{1,79}$ \\
\hline Temperatura $\left({ }^{\circ} \mathrm{C}\right)$ & 22,7 & 22,4 & 21,6 & 23,6 & 22,6 & 22,8 & 22,3 & 23,8 & 22,0 & 21,1 & 23,2 & 20,5 \\
\hline Condutiv. Elétrica $\left(\mu \mathrm{S} / \mathrm{cm}\right.$ a $\left.25^{\circ} \mathrm{C}\right)$ & 15,90 & 16,20 & 8,41 & 13,78 & 12,90 & 10,60 & 9,60 & 6,90 & 31,80 & 27,30 & 28,80 & 15,90 \\
\hline $\mathrm{pH}$ & 5,3 & 5,3 & 5,1 & 5,5 & 5,2 & 4,5 & 4,7 & 5,1 & 6,0 & 5,1 & 5,7 & 5,5 \\
\hline Alcalin. TAC (mg/ de $\mathrm{CaCO}_{3}$ ) & 6,8 & 2,1 & 2,5 & 7,3 & 6,2 & 2,1 & 1,8 & 1,5 & 9,4 & 9,8 & 8,0 & 6,8 \\
\hline Dureza TotaL $\left(\mathrm{mg} / \mathrm{L}\right.$ de $\left.\mathrm{CaCO}_{3}\right)$ & 6,8 & 2,1 & 2,5 & 7,3 & 6,2 & 2,1 & 1,8 & 1,5 & 9,4 & 9,8 & 8,0 & 6,8 \\
\hline Cálcio (mg/L) & 2,72 & 0,84 & 1,00 & 2,92 & 2,48 & 0,84 & 0,72 & 0,60 & 3,76 & 3,92 & 3,20 & 2,72 \\
\hline Magnésio (mg/L) & 0,00 & 0,00 & 0,00 & 0,00 & 0,00 & 0,00 & 0,00 & 0,00 & 0,00 & 0,00 & 0,00 & 0,00 \\
\hline Sódio (mg/L) & 0,1 & 0,6 & 0,5 & 0,5 & 0,5 & 0,4 & 0,4 & 0,3 & 0,8 & 0,7 & 1,1 & 0,6 \\
\hline Potássio (mg/L) & 0,1 & 0,2 & 0,1 & 0,5 & 0,4 & 0,5 & 0,4 & 0,3 & 2,9 & 0,7 & 2,4 & 0,3 \\
\hline Bicarbonato $(\mathrm{mg} / \mathrm{L})$ & 8,30 & 2,56 & 3,05 & 8,91 & 7,56 & 2,56 & 2,20 & 1,83 & 11,47 & 11,96 & 9,76 & 8,30 \\
\hline Cloreto (mg/L) & 0,80 & 0,50 & 0,90 & 0,85 & 0,85 & 1,10 & 1,10 & 1,00 & 1,90 & 1,40 & 2,25 & 0,90 \\
\hline Sulfato $(\mathrm{mg} / \mathrm{L})$ & 0,000 & 0,339 & 0,000 & 0,198 & 0,000 & 0,000 & 0,000 & 0,000 & 0,100 & 0,000 & 0,000 & 0,000 \\
\hline Amônia (mg/L) & $<0,020$ & 0,020 & $<0,020$ & $<0,020$ & $<0,020$ & $<0,020$ & $<0,020$ & $<0,020$ & 0,940 & 0,090 & $<0,020$ & $<0,020$ \\
\hline Nitrito $(\mathrm{mg} / \mathrm{L})$ & $<0,002$ & $<0,002$ & $<0,002$ & $<0,002$ & $<0,002$ & $<0,002$ & $<0,002$ & $<0,002$ & 0,002 & 0,002 & $<0,002$ & $<0,002$ \\
\hline Nitrato (mg/L) & $<0,031$ & 0,172 & $<0,031$ & $<0,031$ & $<0,031$ & $<0,031$ & $<0,031$ & $<0,031$ & 0,120 & 0,190 & 0,330 & $<0,031$ \\
\hline $\mathrm{CO}_{2}$ livre $(\mathrm{mg} / \mathrm{L})$ & 27,9 & 8,0 & 19,0 & 8,8 & 19,0 & 40,0 & 40,0 & 12,6 & 11,4 & 25,2 & 8,0 & 22,2 \\
\hline $\mathrm{O}_{2}$ Consumido $\left(\mathrm{mg} / \mathrm{L}\right.$ de $\left.\mathrm{KMnO}_{4}\right)$ & 0,21 & 0,54 & 0,51 & 1,74 & 0,62 & 2,32 & 0,50 & 0,56 & 30,35 & 0,82 & 0,73 & 1,52 \\
\hline Ferro Total (mg/L) & 0,19 & $<0,03$ & 0,41 & 0,07 & 0,03 & 0,08 & 0,06 & 0,07 & 1,46 & 0,08 & 0,14 & 0,53 \\
\hline itb (indice de troca de bases) & 0,115 & $-0,330$ & 0,021 & $-0,070$ & $-0,065$ & 0,019 & 0,093 & 0,248 & $-0,289$ & $-0,045$ & $-0,277$ & $-0,062$ \\
\hline SAR (sodium absorption ratio) & 0,02 & 0,18 & 0,14 & 0,08 & 0,09 & 0,12 & 0,13 & 0,11 & 0,11 & 0,10 & 0,17 & 0,10 \\
\hline Erro na análise (\%) & $-5,32$ & 5,19 & $-0,79$ & 1,70 & 2,56 & $-0,61$ & $-2,70$ & $-6,92$ & 9,39 & 1,09 & 8,06 & 2,42 \\
\hline Coliformes Totais (NMP/100 ml) & Ausência & 300 & $>1600$ & $>1600$ & 170 & 50 & 30 & 170 & $>1600$ & $>900$ & $>1600$ & 170 \\
\hline Coliformes Fecais (NMP/100 ml) & Ausência & Ausência & 22 & Ausência & Ausência & Ausência & Ausência & Ausência & 30 & 4 & 8 & Ausência \\
\hline Data de coleta & $20 / \mathrm{Jul}$ & 27/Jul & $20 / \mathrm{Jul}$ & $22 / \mathrm{Jul}$ & $22 / \mathrm{Jul}$ & $22 / \mathrm{Jul}$ & 22/Jul & 22/Jul & 22/Jul & $22 / \mathrm{Jul}$ & $22 / \mathrm{Jul}$ & 22/Jul \\
\hline
\end{tabular}

nm: não medido 


\begin{tabular}{|c|c|c|c|c|c|c|c|c|c|c|c|c|c|}
\hline ParâmetroslPoços profundos & P5 & P12 & P15 & $\mathbf{P 1 7}$ & P24 & P28 & P32 & P36 & P41 & P43 & P49 & P50 & P56 \\
\hline Cor (Pt/L) & 16 & 30 & 3 & 2 & 2 & 4 & 5 & 3 & 2 & 5 & 3 & 2 & 5 \\
\hline Turbidez (UNT) & 12,80 & 18,80 & 2,56 & 1,80 & 0,16 & 0,86 & 1,07 & 0,46 & 0,29 & 0,92 & 0,68 & 0,26 & 0,81 \\
\hline Temperatura $\left({ }^{\circ} \mathrm{C}\right)$ & 23,8 & 23,9 & 27,8 & 24,9 & 23,2 & $\mathrm{~nm}$ & $\mathrm{~nm}$ & 23,4 & 27,3 & 24,4 & 23,4 & 23,0 & 26,2 \\
\hline Condutiv. Elétrica $\left(\mu \mathrm{S} / \mathrm{cm}\right.$ a $\left.25^{\circ} \mathrm{C}\right)$ & 34,60 & 19,90 & 36,60 & 10,70 & 29,10 & 15,10 & 9,26 & 11,22 & 35,70 & 54,10 & 12,33 & 16,60 & 21,80 \\
\hline $\mathrm{pH}$ & 6,1 & 5,9 & 6,1 & 5,4 & 5,8 & 5,0 & 5,0 & 4,7 & 6,2 & 6,5 & 5,1 & 4,9 & 5,9 \\
\hline Alcalin. TAC (mg/l de $\left.\mathrm{CaCO}_{3}\right)$ & 13,8 & 6,2 & 11,6 & 3,1 & 8,4 & 5,4 & 0,8 & 1,0 & 13,6 & 20,1 & 2,0 & 1,0 & 9,9 \\
\hline Dureza TotaL $\left(\mathrm{mg} / \mathrm{L}\right.$ de $\left.\mathrm{CaCO}_{3}\right)$ & 13,0 & 6,2 & 15,3 & 3,1 & 8,4 & 5,4 & 0,8 & 1,0 & 19,8 & 20,3 & 2,0 & 1,0 & 11,0 \\
\hline Cálcio (mg/L) & 5,12 & 2,48 & 4,36 & 1,24 & 3,36 & 2,16 & 0,32 & 0,40 & 4,64 & 6,40 & 0,80 & 0,40 & 3,60 \\
\hline Magnésio (mg/L) & 0,05 & 0,00 & 1,07 & 0,00 & 0,00 & 0,00 & 0,00 & 0,00 & 1,99 & 1,04 & 0,00 & 0,00 & 0,49 \\
\hline Sódio $(\mathrm{mg} / \mathrm{L})$ & 0,2 & 0,3 & 1,8 & 0,7 & 2,0 & 0,5 & 0,3 & 0,0 & 0,4 & 0,4 & 0,1 & 1,6 & 0,2 \\
\hline Potássio (mg/L) & 0,3 & 0,5 & 0,9 & 0,4 & 0,6 & 0,1 & 0,2 & 0,0 & 1,5 & 3,3 & 0,1 & 0,3 & 0,4 \\
\hline Bicarbonato (mg/L) & 16,84 & 7,56 & 14,15 & 3,78 & 10,25 & 6,59 & 0,98 & 1,22 & 16,59 & 24,52 & 2,44 & 1,22 & 12,08 \\
\hline Cloreto $(\mathrm{mg} / \mathrm{L}$ ) & 0,55 & 0,30 & 1,25 & 0,35 & 1,20 & 0,20 & 0,25 & 0,35 & 0,40 & 0,30 & 0,35 & 0,95 & 0,30 \\
\hline Sulfato (mg/L) & 0,491 & 0,782 & 4,720 & 0,557 & 0,000 & 0,000 & 0,000 & 0,164 & 1,318 & 0,000 & 0,000 & 0,000 & 0,000 \\
\hline Amônia (mg/L) & $<0,02$ & $<0,02$ & $<0,02$ & 0,030 & 1,250 & 0,090 & $<0,02$ & $<0,02$ & $<0,02$ & $<0,02$ & $<0,02$ & $<0,02$ & 0,250 \\
\hline Nitrito $(\mathrm{mg} / \mathrm{L})$ & $<0,002$ & $<0,002$ & 0,002 & $<0,002$ & $<0,002$ & $<0,002$ & $<0,002$ & $<0,002$ & $<0,002$ & $<0,002$ & $<0,002$ & $<0,002$ & $<0,020$ \\
\hline Nitrato (mg/L) & 0,045 & $<0,031$ & 0,040 & 0,050 & 0,390 & $<0,031$ & $<0,031$ & $<0,031$ & $<0,031$ & 0,042 & $<0,031$ & 0,435 & 0,040 \\
\hline $\mathrm{CO}_{2}$ livre $(\mathrm{mg} / \mathrm{L})$ & 8,9 & 15,1 & 15,0 & 15,1 & 16,0 & 39,8 & 31,7 & 20,0 & 1,0 & 12,6 & 25,2 & 25,2 & 20,0 \\
\hline $\mathrm{O}_{2}$ Consumido $\left(\mathrm{mg} / \mathrm{L}\right.$ de $\left.\mathrm{KMnO}_{4}\right)$ & 0,61 & 0,06 & 0,14 & 0,87 & 0,20 & 0,02 & 0,50 & 0,42 & 1,03 & 0,73 & 1,05 & 0,82 & 0,02 \\
\hline Ferro Total $(\mathrm{mg} / \mathrm{L})$ & 1,76 & 2,43 & 0,18 & 0,14 & 0,04 & 0,21 & 0,04 & 0,05 & 0,35 & 2,32 & 1,29 & $<0,03$ & 2,49 \\
\hline itb (indice de troca de bases) & $-0,003$ & $-0,124$ & $-0,200$ & $-0,414$ & $-0,393$ & $-0,173$ & $-0,692$ & 0,421 & $-0,148$ & $-0,232$ & 0,074 & $-1,868$ & $-0,053$ \\
\hline SAR (sodium absorption ratio) & 0,02 & 0,05 & 0,2 & 0,17 & 0,3 & 0,09 & 0,15 & 0,00 & 0,04 & 0,04 & 0,03 & 0,7 & 0,03 \\
\hline Erro na análise (\%) & $-4,61$ & 0,28 & 5,3 & 9,79 & 12,92 & 7,47 & 19,24 & $-25,04$ & 18,46 & 10,44 & $-3,16$ & 28,76 & 7,14 \\
\hline Coliformes Totais (NMP/100 ml) & Ausência & Ausência & 8 & Ausência & Ausência & Ausência & Ausência & Ausência & Ausência & Ausência & Ausência & Ausência & Ausência \\
\hline Coliformes Fecais (NMP/100 ml) & Ausência & Ausência & Ausência & Ausência & Ausência & Ausência & Ausência & Ausência & Ausência & Ausência & Ausência & Ausência & Ausência \\
\hline Data de coleta & 29/JuI & 29/Jul & $27 / \mathrm{Jul}$ & $27 / \mathrm{Jul}$ & $29 / \mathrm{Jul}$ & $31 / \mathrm{Jul}$ & $31 / \mathrm{Jul}$ & 29/Jul & 29/Jul & $29 / \mathrm{Jul}$ & 29/Jul & $27 / \mathrm{Jul}$ & 29/Jul \\
\hline
\end{tabular}

nm: não medido 


\begin{tabular}{|c|c|c|c|c|c|c|c|c|c|c|c|c|}
\hline ParâmetrosiPoços profundos & P58 & $\mathbf{P 6 0}$ & P62 & P64 & P66 & P69 & P71 & P73 & P74 & P83 & P84 & P88 \\
\hline Cor $(P t L)$ & 5 & 2 & 3 & 8 & 22 & 2 & 3 & 60 & 18 & 3 & 3 & 12 \\
\hline Turbidez (UNT) & 1,07 & 0,26 & 0,26 & 4,07 & 9,12 & 0,38 & 0,50 & 29,10 & 6,44 & 0,45 & 0,54 & 6,86 \\
\hline Temperatura $\left({ }^{\circ} \mathrm{C}\right)$ & $\mathrm{nm}$ & $\mathrm{nm}$ & 23,6 & $\mathrm{~nm}$ & $\mathrm{~nm}$ & 23,0 & $\mathrm{~nm}$ & $\mathrm{~nm}$ & $\mathrm{~nm}$ & $\mathrm{~nm}$ & $\mathrm{~nm}$ & 23,6 \\
\hline Condutiv. Elétrica $\left(\mu \mathrm{S} / \mathrm{cm}\right.$ a $\left.25^{\circ} \mathrm{C}\right)$ & 25,70 & 8,60 & 11,58 & 10,52 & 5,64 & 18,30 & 44,90 & 198,30 & 17,68 & 20,75 & 11,49 & 6,67 \\
\hline $\mathrm{pH}$ & 5 & 5,2 & 4,9 & 5,3 & 4,9 & 4,7 & 4,6 & 7,7 & 6,2 & 5,3 & 4,9 & 5,3 \\
\hline Alcalin. TAC $\left(\mathrm{mg} / \mathrm{de} \mathrm{CaCO}_{3}\right)$ & 2,4 & 2,6 & 1,3 & 1,6 & 1,6 & 0,6 & 0,8 & 127,0 & 5,4 & 0,8 & 1,3 & 2,6 \\
\hline Dureza TotaL $\left(\mathrm{mg} / \mathrm{L}\right.$ de $\left.\mathrm{CaCO}_{3}\right)$ & 2,4 & 2,6 & 1,3 & 1,6 & 1,6 & 0,6 & 0,8 & 130,2 & 5,4 & 0,8 & 1,3 & 2,6 \\
\hline Cálcio (mg/L) & 0,96 & 1,02 & 0,56 & 0,64 & 0,64 & 0,24 & 0,32 & 42,54 & 2,16 & 0,32 & 0,52 & 1,04 \\
\hline Magnésio (mg/L) & 0,00 & 0,00 & 0,00 & 0,00 & 0,00 & 0,00 & 0,00 & 5,79 & 0,00 & 0,00 & 0,00 & 0,00 \\
\hline Sódio (mg/L) & 0,4 & 0,5 & 0,2 & 0,3 & 0,6 & 0,9 & 6,2 & 0,5 & 0,5 & 0,3 & 0,1 & 0,3 \\
\hline Potássio $(\mathrm{mg} / \mathrm{L})$ & 0,2 & 0,4 & 0,3 & 0,2 & 0,1 & 0,2 & 0,9 & 0,3 & 0,2 & 0,1 & 0,1 & 0,3 \\
\hline Bicarbonato (mg/L) & 2,93 & 3,17 & 1,59 & 1,95 & 1,95 & 0,73 & 0,98 & 154,94 & 6,59 & 0,98 & 1,59 & 3,17 \\
\hline Cloreto $(\mathrm{mg} / \mathrm{L})$ & 0,20 & 0,25 & 0,75 & 0,20 & 0,20 & 0,65 & 5,55 & 0,20 & 0,20 & 0,20 & 0,15 & 0,70 \\
\hline Sulfato $(\mathrm{mg} / \mathrm{L})$ & 0,000 & 0,000 & 0,000 & 0,000 & 0,000 & 0,000 & 0,000 & 0,150 & 0,000 & 0,000 & 0,000 & 0,198 \\
\hline Amônia (mg/L) & $<0,02$ & $<0,02$ & $<0,02$ & $<0,02$ & $<0,02$ & $<0,02$ & $<0,02$ & $<0,02$ & $<0,02$ & $<0,02$ & $<0,02$ & 0,040 \\
\hline Nitrito $(\mathrm{mg} / \mathrm{L})$ & $<0,002$ & $<0,002$ & $<0,002$ & $<0,002$ & $<0,002$ & $<0,002$ & $<0,002$ & $<0,002$ & $<0,002$ & $<0,002$ & $<0,002$ & 0,005 \\
\hline Nitrato $(\mathrm{mg} / \mathrm{L})$ & $<0,031$ & 0,131 & $<0,031$ & $<0,031$ & 0,085 & 0,302 & 0,690 & 0,084 & $<0,031$ & $<0,031$ & $<0,031$ & $<0,031$ \\
\hline $\mathrm{CO}_{2}$ livre $(\mathrm{mg} / \mathrm{L})$ & 6,3 & 37,9 & 15,9 & 15,9 & 6,3 & 12,6 & 50,2 & 8,2 & 6,3 & 20,0 & 15,9 & 23,9 \\
\hline $\mathrm{O}_{2}$ Consumido $\left(\mathrm{mg} / \mathrm{L}\right.$ de $\left.\mathrm{KMnO}_{4}\right)$ & 0,04 & 1,50 & 0,83 & 0,30 & 0,40 & 0,06 & 0,02 & 1,22 & 0,04 & 0,02 & 1,16 & 0,48 \\
\hline Ferro Total (mg/L) & 0,03 & $<0,03$ & 0,20 & 0,27 & 0,10 & 0,08 & 0,05 & 0,49 & 0,30 & 0,05 & 0,05 & 0,46 \\
\hline itb (indice de troca de bases) & $-0,351$ & $-0,461$ & 0,183 & $-0,392$ & $-0,690$ & $-1,540$ & $-8,481$ & $-0,009$ & $-0,196$ & $-0,620$ & $-0,103$ & $-0,018$ \\
\hline SAR (sodium absorption ratio) & 0,11 & 0,14 & 0,07 & 0,10 & 0,21 & 0,51 & 3,02 & 0,02 & 0,09 & 0,15 & 0,04 & 0,08 \\
\hline Erro na análise (\%) & 13,48 & 15,09 & $-3,16$ & 14,23 & 21,69 & 23,06 & 25,4 & 1,53 & 8,43 & 18,52 & 4,04 & $-2,17$ \\
\hline Coliformes Totais (NMP/100 ml) & Ausência & Ausência & Ausência & Ausência & Ausência & Ausência & Ausência & Ausência & Ausência & 8 & Ausência & Ausência \\
\hline Coliformes Fecais (NMP/100 ml) & Ausência & Ausência & Ausência & Ausência & Ausência & Ausência & Ausência & Ausência & Ausência & Ausência & Ausência & Ausência \\
\hline Data de coleta & $31 / \mathrm{Jul}$ & 31/Jul & 29/Jul & $31 / \mathrm{Jul}$ & $31 / \mathrm{Jul}$ & $29 / \mathrm{Jul}$ & $31 / \mathrm{Jul}$ & $31 / \mathrm{Jul}$ & $31 / \mathrm{Jul}$ & $31 / \mathrm{Jul}$ & $31 / \mathrm{Jul}$ & $27 / \mathrm{Jul}$ \\
\hline
\end{tabular}

nm: não medido 